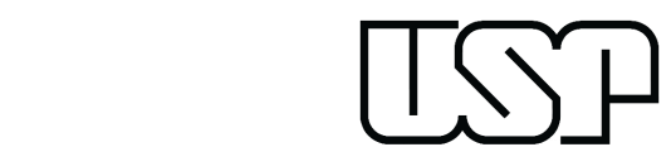

Departamento de Letras Modernas

FACULdADE DE Filosofia LeTRAS E CiÊNCIAS HumanAS

UNIVERSIDAdE de SÃo PAULO

JAIME CARÁ JUNIOR

\title{
O conceito de interação no discurso publicitário sobre a aula de inglês
}

Tese de Doutorado em

Estudos Linguísticos e Literários em Inglês

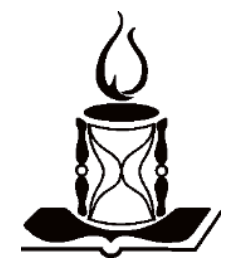

São Paulo 2017 


\section{O conceito de interação no discurso publicitário sobre a aula de inglês}

Tese apresentada ao Departamento de Letras Modernas da Faculdade de Filosofia Letras da Universidade de São Paulo para obtenção do título de Doutor em Letras.

\section{Área de Concentração}

Estudos Linguísticos e Literários em Inglês

Orientadora

Profa. Dra. Anna Maria G. Carmagnani

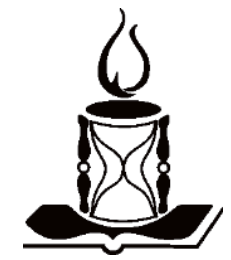

São Paulo

2017 
Autorizo a reprodução e divulgação total ou parcial deste trabalho, por qualquer meio convencional ou eletrônico, para fins de estudo e pesquisa, desde que citada a fonte.

Catalogação na Publicação

Serviço de Biblioteca e Documentação

Faculdade de Filosofia, Letras e Ciências Humanas da Universidade de São Paulo

C257c Cará Junior, Jaime

O conceito de interação no discurso publicitário sobre a aula de inglês / Jaime Cará Junior ; orientadora Anna Maria Grammatico Carmagnani Carmagnani. - São Paulo, 2007. $208 \mathrm{f}$.

Tese (Doutorado) - Faculdade de Filosofia, Letras e Ciências Humanas da Universidade de São Paulo. Departamento de Letras Modernas. Área de concentração: Estudos Linguísticos e Literários em Inglês.

1. Interação. 2. Análise Discursiva. 4. Mídia Publicitária. I. Carmagnani, Anna Maria Grammatico Carmagnani, orient. II. Título. 
Cará Junior, Jaime. O conceito de interação no discurso publicitário sobre a aula de inglês. Tese apresentada à Faculdade de Filosofia Letras e Ciências Humanas da Universidade de São Paulo para obtenção do título de Doutor em Letras.

\section{Banca Examinadora}

Aprovado em:

Prof(a). Dr(a).

Instituição

Julgamento

Assinatura

Prof(a). Dr(a).

Instituição

Julgamento

Assinatura

Prof(a). Dr(a).

Instituição

Julgamento

Assinatura

Prof(a). Dr(a).

Instituição

Julgamento

Assinatura

Prof(a). Dr(a).

Instituição

Julgamento

Assinatura 
Dedicado a JAIME CARÁ

(1930-2005) 
Agradeço à Anna Maria Carmagnani por caminhar junto nos meus primeiros passos acadêmicos e por mais de uma década de orientação, desde meu trabalho de graduação até a presente tese, à Maria lara Porto da Costa por todo o suor e o amor graças aos quais conseguimos superar tempos difíceis, e à Samantha Mesojedovas Cará pelo carinho, amor, apoio e compreensão que fizeram toda a diferença para esta tese e para a minha vida.

Também agradeço à Luciana Locks pela amizade valiosa e todo o cuidado despendido, ao Anderson Florêncio da Silva pela mais profunda relação fraterna, ao Caio Parada Cabral pela amizade e as reflexões acadêmicas, à minha valiosa família, e aos meus queridos amigos.

Agradeço ainda às instituições onde trabalhei e com quem contribuí nos últimos anos, onde tive muitas oportunidades de desenvolvimento. 
"Nobody reads ads. People read what interests them, and sometimes it's an ad."

Howard Luck Gossagi 


\section{RESUMO}

Cará Junior, Jaime. O conceito de interação no discurso publicitário sobre a aula de inglês. 2017. 208 f. Tese (Doutorado) - Faculdade de Filosofia Letras e Ciências Humanas, Universidade de São Paulo, São Paulo, 2017.

O objetivo desta tese foi investigar o conceito de interatividade no modo de funcionamento do discurso da mídia publicitária ao representar a sala de aula de língua inglesa em contextos de escolas de cursos livres associada a determinadas práticas de ensino, mas não necessariamente a objetivos educacionais. Para tanto, analisamos as condições sócio-históricas do discurso da mídia publicitária, principalmente em anúncios de cursos livres de inglês, e as regularidades da formação desse discurso sobre a interação na sala de aula desses cursos, descrevendo sua dispersão em quatro níveis (FOUCAULT, 1969/2009): nos níveis dos objetos, dos tipos enunciativos, dos temas e teorias e, principalmente, no nível do conceito (de interação). Além disso, refletimos sobre os mecanismos discursivos que mobilizam o poder de influência do discurso da mídia publicitária, e sobre as representações e o conceito de interação e de interatividade. Com esse objetivo, e baseando-nos nessas reflexões e em análises discursivas, sustentamos a tese de que o discurso da mídia publicitária exerce uma influência condicional sobre outros discursos (inclusive sobre o científico), sendo ele sujeito a regras de uma ordem que interditam o engendramento de conceitos no interior de sua própria formação discursiva. O discurso da mídia publicitária pode e deve ser original, desde que se submeta a dizer sempre o já dito. Dessa forma, afirmamos que as representações publicitárias da interação que as salas de aula e as novas tecnologias proporcionam fazem parte de uma engrenagem de influência na mesma medida em que articulam processos de atualização, no sentido deleuziano (DELEUZE, 1988/2006), de memórias discursivas, nas quais o ensino e aprendizagem de inglês e a interação são representados e exacerbados como experiências eficazes, prazerosas, agradáveis, encantadoras e afetuosas, no caso das escolas de cursos livres, e ineficazes, tediosas, maçantes, fastidiosas, enfadonhas e requerendo muito esforço, no caso das escolas do ensino regular. O discurso da mídia publicitária sobre a sala de aula de inglês em escolas livres e suas qualidades de interação constitui um sistema de dispersão que mobiliza, reitera, sedimenta e retoma sentidos que atravessam outros discursos. Isso pode levar à apressada conclusão de que o 
discurso da mídia publicitária influencia outros discursos, principalmente se crermos que esse discurso se constitui como uma espécie de fluxo da produção à recepção. Assim, o conceito de interação não é exatamente influenciado nem imposto, mas, em uma engrenagem que o empodera na mesma medida em que o submete, 0 discurso da mídia publicitária reproduz o conceito de interação como valor a ser atribuído ao produto ou serviço anunciado, justamente submetido à forma sedimentada desse conceito na memória discursiva, de onde advém sua disposição como verdadeiro.

Palavras-chave: Interação. Mídia publicitária. Análise discursiva. 


\begin{abstract}
Cará Junior, Jaime. The concept of interaction in advertising discourse about the English class. 2017. 208 f. Tese (Doutorado) - Faculdade de Filosofia Letras e Ciências Humanas, Universidade de São Paulo, São Paulo, 2017.
\end{abstract}

This thesis aims at investigating the concept of interactivity in the functioning of the media discourse when advertising language schools and representing the English language classroom. To accomplish this objective, we analyze the sociohistorical conditions of the advertising media discourse (mainly in language schools' advertisements) and the regularities of the formation of this discourse on its interaction in the English language classroom, describing their dispersion at four levels (FOUCAULT, 1969/2009): the formation of objects of discourse, the formation of enunciative positions or modes, the formation of theoretical strategies, and the formation of concepts. Still in consistency with this objective, we reflect upon the discursive mechanisms that mobilize the supposedly powerful influence of advertising media discourse, and upon the representations and the concept of interaction and interactivity. With such objective and based on these considerations and on discursive analysis, we substantiated the hypothesis that the media discourse exerts a conditional influence on other discourses (including scientific discourse), being subjected to the rules of an order that prevents it from engendering concepts within its own discursive formation. Advertising media discourse can and should be original, as long as it commits to repeating what has already been said. Thus, it is possible to argue that the advertising representations of the interaction supposedly provided by that English language classroom and the communication technologies take part in a seducing machinery and, at the same time, is subjected to a process of realization, in the Deleuzian sense (DELEUZE, 1988/2006), of discursive memories, in which English teaching and learning and interaction are represented and exacerbated as effective, pleasurable, fun, and friendly experiences in the case of language schools, and as ineffective, tedious, uninteresting, and demanding experiences in the case of regular schools. The discourse of advertising media on interaction and interactivity constitutes a system of dispersion that mobilizes, reiterates, sediments, and resumes senses that largely permeates or intersects other discourses, and may lead to the 
false conclusion that the discourse of advertising media influences other discourses, especially if we are oblivious to the equally false assumption that such discourse constitutes a kind of flow from production to reception. The concept of interaction is, thus, not influenced or imposed by media discourse. In a machinery that at the same time empowers and subjects it, the advertising media discourse reproduces the concept of interaction as a quality to be attributed to advertised goods and services, being responsive to the sedimented concept in the discursive memory, from where it draws its status of truth.

Key-words: Interaction. Advertising media. Discourse analysis. 


\title{
O CONCEITO DE INTERAÇÃO NO DISCURSO PUBLICITÁRIO SOBRE A AULA DE INGLÊS
}

\author{
Jaime Cará Junior \\ Faculdade de Filosofia Letras e Ciências Humanas \\ Universidade de São Paulo
}

\section{Sumário}

Introdução

Capítulo 1

Perspectiva teórica e procedimentos metodológicos

1. Constituição do corpus___ 023

2. Sujeito__ 027

3. Discurso__ 029

4. Discurso como sistema aberto _ 033

5. Conclusões _ 038

Capítulo 2

Contexto socio-histórico e seus nós de coerção

1. Neoescolanovismo, neoprodutivismo e neotecnicismo__ 039

2. Sala de aula espetacular e sua espetacularização___ 047

3. O "verdadeiro" no contexto de cursos livres de inglês___ 049

4. Conclusões___ 053

Capítulo 3

O problema da interação__ 055

1. Desfiguração do construtivismo e do socioconstrutivismo___ 056

2. O "novo" em formulações antigas___ 058

3. Proposições para compreender a interação___ 075

4. Qualidades da interação em planos de aula__ 083

5. Conclusões__ 093

Capítulo 4

Regras de dispersão do discurso da mídia publicitária___ 097

1. A formação dos objetos__ 099

2. A formação das modalidades enunciativas___ 102

3. A formação dos conceitos___ 104

4. A formação das estratégias___ 108

5. Conclusões__ 110

Capítulo 5

A influência do e sobre o discurso da mídia publicitária como tensão constitutiva___ 113

1. O discurso da mídia publicitária em análise___ 115

1.1. Influência do discurso da mídia___ 115

1.2. Produção e veiculação de textos__ 117 
1.3. Disjunção temporal e espacial

1.4. Tensão constitutiva

2. Análise de textos publicitários 126

3. Análise do discurso do vendedor 181

4. Análise do discurso do consumidor

5. Análise do discurso do professor 191

6. Conclusões

Considerações Finais 197

Referências bibliográficas 202 


\title{
Introdução
}

\begin{abstract}
"Há quem diga que a publicidade afeta os hábitos sociais, mas eu não concordo com isso. Em vez de influenciar costumes, ele apenas os reflete. (...) Ela tem, sem dúvida, algum poder de fazer as pessoas comprarem o produto. (...) Mas é um mito achar que todo anúncio vende qualquer coisa. A informação transmitida pela publicidade precisa ser honesta e verdadeira, e precisa representar para o indivíduo um apoio às decisões que mais the convenham na livre escolha dos bens e serviços de que necessita".
\end{abstract}

David Olgivy, 1970

Ainda antes de haver televisão a cores no Brasil, já se refletia sobre a influência da publicidade. Em um tempo histórico anterior à formação das grandes redes televisivas, à consolidação da hegemonia neoliberal e do movimento de globalização, à emergência da internet e ao rápido e agudo desenvolvimento das tecnologias da comunicação, talvez fossem mais comuns os argumentos de que a influência da mídia, especialmente a jornalística e a publicitária, deveria ser relativizada. Ao menos aparentemente, "atualmente ninguém duvida da forte influência que a publicidade exerce sobre a população e sua conduta na sociedade de consumo" (ATZ e ROCHA, 2008). Nos nossos tempos, a sedução passa a ser uma característica presumida do discurso publicitário como meio para influenciar os 
sujeitos, não apenas levando-os a consumir, mas também a incorporarem as formas de ser e de pensar impostos pela publicidade. Acredita-se que:

(...) a publicidade é normativa: ela postula, expõe, impõe uma nova escala de valores, um novo estilo. Ela diz a todos os homens da civilização ocidental como convém viver e ser, trabalhar e divertir-se, ser eternamente amado, jovem e feliz, e cria, aproveitando a crise cultural, novos conceitos do que é bom e desejável. (CARVALHO, 2014, p. 31)

Sendo essa condição ou status da mídia publicitária presumida, restaria apenas refletir sobre como iniciativas de áreas específicas atingem determinados públicos, em uma lógica linear de produtores e receptores de informação. De que forma a publicidade de um produto de determinado setor articula a influência sobre determinado público? Del Monte (2011, p. 3), por exemplo, defende que "a propaganda televisiva das redes varejistas tem influência no comportamento do consumidor de baixa renda".

Eis um campo fértil para diversas reflexões. Seria realmente a publicidade dotada de tamanho poder? Poderíamos de fato pressupor que o discurso da mídia publicitária operasse a partir de lugares tão privilegiados na ordem do discurso, talvez até imune a suas coerções e interdições externas? Quando uma escola de inglês anuncia seu curso, poder-se-ia presumir que se trata de um exercício de influência com relação a como uma aula de inglês é ou deve ser? Estariam os professores, alunos e potenciais consumidores do curso submetidos, irremediavelmente, aos efeitos dessa influência, restando-lhes resistir bravamente? Por que, afinal, as aulas de inglês são representadas dinâmicas e motivadoras?

Nossa sociedade do espetáculo (DEBORD, 1997/2013), nossa cibercultura (LÉVY, 1999) ou nossa modernidade líquida (BAUMAN, 1999) certamente tem como um de seus traços mais marcantes uma "indústria" da interatividade (SILVA, 2004), ou seja, um conjunto de forças e dispositivos que funciona para capturar os sujeitos de forma a garantir o engajamento do sujeito-consumidor. Essa indústria é cada vez mais importante no funcionamento do mercado neoliberal ${ }^{1}$. As empresas e instituições precisam de acesso ao mercado consumidor tanto no sentido de se anunciar produtos

\footnotetext{
${ }^{1}$ Os valores neoliberais são definidos pelo grau máximo de "liberdade" econômica atribuída aos indivíduos e pela pretensão da economia de mercado de assumir ao mesmo tempo a relação pessoal e a relação social, impondo aos sujeitos uma distância de si mesmo em relação a si mesmo (ou seja, estabelecendo a impossibilidade de sermos si mesmo) ao atribuir a cada sujeito a tarefa de ser-simesmo (DUFOUR, 2001 e 2005).
} 
e serviços, quanto no de obter informações dos (e não sobre) consumidores, sendo a mídia (em sentido amplo) uma frequente e poderosa intermediária desse acesso.

No caso do consumo de cursos de inglês no Brasil, há um consenso crescente no mercado segundo o qual não se aprende inglês na escola regular, mas sim na escola de cursos livres $^{2}$ especializada, o que contribuiu para impulsionar o crescimento do mercado de franquias de escola de inglês ${ }^{3}$ e a participação dessas instituições na mídia, disputando consumidores.

A primeira franquia de escolas de inglês no Brasil é de 1950. Nos anos 60 e 70, houve o surgimento de muitas marcas, mas o período de maior crescimento do mercado de ensino de inglês é a partir dos anos $90^{4}$, que é também quando se inicia o período em que a internet mais se desenvolve no Brasil. É também a partir dos anos 90 que a indústria da interatividade cresce, impulsionada pelo desenvolvimento das tecnologias de comunicação.

Nesse cenário, a interatividade torna-se um argumento de venda e, como tal, é embebido em positividade. A ela são atribuídas características valiosas, em uma sociedade como a nossa, para a venda e o consumo. Interatividade é associada a mais e melhor experiências, controle, poder de intervenção, opções ou possibilidades, responsividade, colaboração e iniciativa. Dizemos mais e melhor experiências no sentido de que elas são prazerosas, divertidas, interessantes, agradáveis e alegres.

A partir dos anos 90, o neoprodutivismo é considerado predominante entre as ideias pedagógicas no Brasil (SAVIANI, 2007/2010) e suas bases tanto didaticopedagógicas (neoescolanovismo) quanto psicopedagógicas (neoconstrutivismo) implicam um deslocamento de foco do conteúdo para o método, do professor para o aluno, do esforço para o interesse e da disciplina para a espontaneidade, sem perder de vista o objetivo de "qualidade total" neoprodutivista (SAVIANI, 2007/2010).

Assim, o curso de inglês é mais atraente se a pessoa puder de fato aprender (ao contrário do que o senso comum supõe que aconteceria na escola regular), porém

\footnotetext{
2 Usamos "cursos livres" conforme os termos da legislação brasileira, ou seja, para designar os cursos que não são regidos por lei específica e que, portanto, não são regulamentados pelo MEC, como é o caso das franquias de escolas de inglês.

${ }^{3}$ Segundo a relatório da ABF, Associação Brasileira de Franquias, o segmento cresceu em torno de $12 \%$ em 2014 e 8,7\% em 2015. O relatório pode ser acessado neste endereço: http://www.portaldofranchising.com.br/central/Content/UploadedFiles/Arquivos/desempenhofranchising-novo-2015.pdf.

${ }^{4}$ Nesse período surgem dez das vinte e uma marcas associadas hoje à ABF, além da proliferação de marcas não franqueadas e profissionais autônomos ministrando aulas de inglês particulares e para pequenos grupos.
} 
de forma descontraída, interessante, divertida, rápida, e sem esforço. A publicidade das escolas de inglês anuncia seus cursos e representa a interação em suas aulas com essas características. A interatividade é tratada como um estado absoluto, um conjunto de características que pode ser contido em algo, ou como um gradiente dessas características. De qualquer forma, se é interativo ou se é mais interativo, vende-se mais; consome-se mais.

Por sua qualidade vendedora, a ideia de interatividade é muito presente nos discursos veiculados nos meios de comunicação em geral. Não acidentalmente, a mídia se apropria do termo. As condições de produção do discurso midiático cada vez mais acentuadamente se fazem presentes nos modos de construção de sentido nas sociedades atuais, e a formação e negociação das subjetividades estão intimamente associadas a esse fenômeno. As ideias associadas aos termos interação e interatividade são cada vez mais generalizadas e tomadas para qualificar as coisas, as relações e as pessoas. Tais ideias são naturalizadas ao ponto de, às vezes, sequer precisarem ser ditas. A expressão de suas qualidades é ouvida e aceita inadvertida e subentendidamente. A interação/interatividade é um valor simbólico produzido e consumido desenfreadamente, e a exaltação e o desejo da interação/interatividade permeiam outras práticas discursivas, inclusive o discurso pedagógico.

Eis as relações com, por exemplo, as ideias do construtivismo e socioconstrutivismo, que talvez encontrem nos dias de hoje seu ápice de popularidade, encantamento e simplificação. É largamente apregoada a ideia de que as novas tecnologias da comunicação são interativas e que, por isso mesmo, a sala de aula seria um lugar melhor com elas. Diz-se, também, que a interação é fundamental para o processo educativo e que a sala de aula, a escola ou qualquer ambiente educacional ou de instrução podem ser tão melhores quanto mais explorarem o uso da interatividade. Quem conseguiria pensar, desavisadamente, que um curso não seria melhor se fosse um curso interativo, ou ainda, que uma aula interativa pudesse não ser 'boa'? Dificilmente alguém afirmaria algo como "estava em uma aula com uma interação excelente" ao invés de "estava em uma aula com muita interação". Não se qualifica a interação entre as pessoas, porque o simples fato de haver interação já é qualificado positivamente.

Esse discurso que idealiza a interatividade se articula com outros que colocam a razão como lugar do marasmo, da chatice, do desinteresse, do tédio. A interatividade 
não está associada a situações como uma conversa "séria", mas a coisas que ganham a atenção e mobilizam os interlocutores.

No sentido dessas reflexões, o objetivo desta tese é investigar o modo de funcionamento do discurso da mídia publicitária ao representar a sala de aula de língua inglesa em contextos de escolas de cursos livres associada a determinado conceito de interação. Mais especificamente, esta tese objetiva:

- Analisar as condições sócio-históricas do discurso da mídia publicitária em anúncios de cursos livres de inglês

- Analisar as regularidades da formação do discurso da mídia publicitária sobre interação em cursos de inglês, descrevendo sua dispersão nos níveis dos objetos, dos tipos enunciativos, dos temas e teorias e, principalmente, no nível do conceito (de interação).

- Refletir sobre os mecanismos discursivos que mobilizam o poder de influência do discurso da mídia publicitária.

- Refletir sobre o conceito de interação.

Os objetivos desta tese encontram justificativa e pertinência ao contribuir para a reflexão sobre as representações e o conceito de interação e de interatividade, e ao investigar o modo de funcionamento e os efeitos de sentido do discurso da mídia ao representar a sala de aula de língua inglesa em contextos de escolas de cursos livres associada a determinado conceito de interação. Ao examinarmos como os mecanismos de persuasão operam nos textos midiáticos publicitários e problematizarmos a ideia de interação/interatividade usada para descrever os objetos e as relações das escolas de inglês representadas nos meios de comunicação midiáticos, é possível também compreender as práticas de consumo envolvendo "interação/interatividade" como valor simbólico. Ou seja, como um efeito de sentido que é reificado e coberto de positividade e consumido em práticas discursivas.

Com esses objetivos, trabalhamos com a tese de que o discurso da mídia publicitária não exerce senão uma influência condicional sobre outros discursos (inclusive sobre o científico), sendo ele sujeito a regras de uma ordem que interditam o engendramento de conceitos no interior de sua própria formação discursiva. Os lugares e posições de enunciação apenas podem mobilizar poder na mesma teia de relações que conjuram seus poderes, limitando seu potencial criativo às temáticas, aos objetos e tipos enunciativos, e interditando sua apropriação de regras de formação 
de conceitos. Dessa forma, afirmamos que as representações publicitárias da interação que as salas de aula e as novas tecnologias proporcionam fazem parte de uma engrenagem de influência na mesma medida em que articulam processos de atualização, no sentido deleuziano (DELEUZE, 1988/2006), de memórias discursivas, nas quais o ensino e aprendizagem de inglês e a interação são representados e exacerbados como experiências eficazes, prazerosas, agradáveis, encantadoras e afetuosas, no caso das escolas de cursos livres, e ineficazes, tediosas, maçantes, fastidiosas, enfadonhas e requerendo muito esforço, no caso das escolas do ensino regular.

Defendemos que o discurso da mídia publicitária sobre a sala de aula de inglês em escolas livres e suas qualidades de interação constitui um sistema de dispersão que mobiliza, reitera, sedimenta e retoma sentidos que atravessam outros discursos. Isso pode levar à apressada conclusão de que o discurso da mídia publicitária influencia outros discursos, principalmente se crermos que esse discurso se constitui como uma espécie de fluxo da produção à recepção.

Assim, o conceito de interação não é exatamente influenciado nem imposto, mas, em uma engrenagem que o empodera na mesma medida em que o submete, o discurso da mídia publicitária reproduz o conceito de interação como valor a ser atribuído ao produto ou serviço anunciado, justamente submetido à forma sedimentada desse conceito na memória discursiva, de onde advém sua disposição como verdadeiro.

Sustentamos essa hipótese a partir de análises e reflexões teóricas orientadas por uma perspectiva discursiva que tem como principais referências as contribuições de Dominique Maingueneau, Michel Foucault e Norman Fairclough, lidando com pontos de coadunação e de conflito entre essas contribuições e tomando como principais pressupostos que:

- o sujeito é dividido e afetado pela linguagem, pela história e pela ideologia;

- o discurso extrapola as bordas de um texto, isto é, as condições de produção do discurso estão inevitavelmente ligadas a um contexto sóciohistórico-cultural específico.

Articulados a essa perspectiva da Análise de Discurso, outros pressupostos têm lugar importante em nossas reflexões teóricas e análise. Ao tratar de 
interatividade como valor simbólico, pressupomos que o consumo de valores simbólicos não constitui um ato individual e sim um conjunto de processos socioculturais de apropriação desses valores, nos quais o discurso midiático constitui e é constituído pelo senso comum (CANCLINI, 1995). Quando analisamos o discurso da mídia publicitária, nós o compreendemos como uma formação discursiva, pressuposta em uma relação com o discurso como "conjunto de enunciados que se apoia em um mesmo sistema de formação" e que permite "falar do discurso clínico, do discurso econômico, do discurso da história natural, do discurso psiquiátrico (FOUCAULT, 1969/2009, p. 122) e do discurso da mídia. Nas reflexões sobre o conceito de interação e interatividade, que frequentemente implica a presença de agentes, pressupomos que a presença seja o conjunto de efeitos (atual) de um acontecimento, uma atualização, não uma condição da substância (CARÁ JR., 2014), tomando a relação entre atual e atualização em termos deleuzianos, ou seja, compreendendo que "o atual é o complemento ou o produto, o objeto da atualização, mas esta não tem por sujeito senão o virtual. [...] O atual cai para fora do plano como fruto, ao passo que a atualização o reporta ao plano como àquilo que reconverte o objeto em sujeito" (DELEUZE, 1996, p. 51).

No desenvolvimento da pesquisa, o corpus analisado é constituído por recortes do discurso da mídia publicitária de cursos de inglês veiculados em vídeo na mídia digital. Compreendendo que esses recortes não devem ser alinhados em um fluxo ou uma sequência de discursos que iria da produção à recepção, ou seja, considerando que a mídia não está em uma das pontas de uma suposta cadeia de produção ideológica enquanto a recepção e as discursividades a partir dela seriam elos subsequentes dessa pressuposta corrente, faz-se necessário compor o corpus também com recortes de outros discursos que constituem o nó de coerções da produção do discurso da mídia publicitária. Assim, também constituem o corpus entrevistas escritas de professores de inglês falando sobre interatividade e comentando peças publicitárias de cursos de inglês veiculados em vídeo na mídia digital, bem como por interações orais de profissionais de vendas com prospects (possíveis clientes/consumidores).

A análise discursiva das entrevistas escritas de professores de inglês falando sobre interatividade e comentando peças publicitárias de cursos de inglês veiculados em vídeo na mídia digital e das interações orais de profissionais de vendas com 
prospects (possíveis clientes/consumidores) coloca a análise dos textos publicitários em perspectiva, permitindo-nos apreender os nós de coerção da produção desses textos. Entendemos que todos esses recortes sejam responsivos e deixem entrever um jogo de forças entre formações discursivas que se articulam em torno de certos princípios de regularidade. Dito de outra forma, o conjunto desses recortes deixa entrever o discurso da mídia sobre a interatividade, entendendo que se constitui como um campo problemático ${ }^{5}$ ou um nó de forças coercivas entre discursos e não propriamente por um campo discursivo 6 recortável em sua própria materialidade textual.

A análise do corpus tem como norte as seguintes perguntas:

- Quais são as regularidades da formação discursiva que permitam a apreensão das regras de dispersão nos níveis dos objetos, dos tipos enunciativos, dos temas e teorias e, principalmente, no nível do conceito (de interação) do discurso da mídia publicitária sobre interação em cursos de inglês?

- Quais são as condições sócio-históricas de produção e circulação do discurso da mídia publicitária que representa a aula em escolas de cursos livres?

- Qual é o modo de funcionamento do discurso midiático em análise com relação aos mecanismos discursivos que mobilizam o poder de influência do discurso da mídia publicitária?

Respondendo a essas perguntas, a tese se apresenta aqui organizada em cinco capítulos, além desta introdução e das considerações finais. O primeiro capítulo é dedicado a descrição dos procedimentos metodológicos, do corpus e da nossa perspectiva teórica. No segundo capítulo, refletimos sobre as condições sóciohistóricas de produção do discurso da mídia publicitária sobre a interação em sala de aula de inglês em escolas livres, abordando nós de coerção ideológicos e possíveis práticas de transformação das formações discursivas que estão em jogo. No capítulo seguinte, refletimos sobre a forma como a idealização da interação (e interatividade)

\footnotetext{
${ }^{5}$ Entendemos campo problemático conforme Deleuze (1996; 1988/2006) ou seja, como o espaço sistemático aberto em que há encontro de acontecimentos que têm um valor, ao mesmo tempo, indeterminado, determinável e de determinação.

${ }^{6}$ Compreendemos "campo discursivo" conforme Charaudeau e Maingenau (2004: 91): "conjunto de formações discursivas (ou de posicionamentos) [que] estão em relação de concorrência no sentido amplo, delimitando-se reciprocamente".
} 
se articula com discursos associados à educação e à sala de aula. No quarto capítulo, debruçamo-nos sobre as regularidades do discurso da mídia, abordando as regras de dispersão nos níveis dos objetos, dos tipos enunciativos, dos temas e teorias e, principalmente, no nível do conceito (de interação) do discurso da mídia publicitária sobre interação em cursos de inglês. No quinto capítulo, analisamos discursivamente peças publicitárias de escolas de idiomas, textos de professores falando sobre interação e gravações de vendedores que tentam vender o curso de inglês usando o argumento da interação. Nessa análise, procuramos compreender o funcionamento do discurso midiático com relação aos mecanismos discursivos que mobilizam o poder de influência do discurso da mídia publicitária. 


\section{Capítulo 1}

\section{PERSPECTIVA TEÓRICA E PROCEDIMENTOS METODOLÓGICOS}

O objetivo deste capítulo é descrever os procedimentos metodológicos de constituição do corpus e a perspectiva discursiva, cuja descrição focaliza os conceitos de sujeito e de discurso. Esse recorte é importante porque estes são os pressupostos teóricos mais centrais das análises, cuja abordagem metodológica é discursiva. $\mathrm{Na}$ última parte deste capítulo, apresentamos uma perspectiva que procura compreender o discurso como sistema aberto, tendo como principais interssessores Deleuze e Guattari (1992/2010; 1995/2011), e argumentando que o sujeito, tanto quanto o sentido, é da ordem dos acontecimentos e não das substâncias.

\section{Constituição do corpus}

O corpus desta tese é constituído por três recortes: discurso da mídia publicitária de cursos de inglês veiculados em vídeo na mídia digital, textos escritos de professores de inglês respondendo a duas perguntas sobre a aprendizagem e a 
aula de inglês, textos escritos de consumidores de cursos de inglês respondendo às mesmas duas perguntas, bem como por interações orais de profissionais de vendas com prospects (possíveis clientes/consumidores). Esses recortes foram demandados e se delinearam pela análise discursiva e principalmente pelo desenvolvimento das reflexões sobre o chamado "fluxo publicitário" (PIEDRAS, 2006), sendo que, em um primeiro momento, apenas os vídeos anunciantes de cursos de inglês compunham o corpus.

A seleção de publicidades de cursos livres de inglês foi feita em meio eletrônico e os arquivos digitais correspondentes são anexos nesta tese ${ }^{7}$. Essa seleção seguiu três critérios, de forma que os vídeos selecionados deviam:

- ser peças publicitárias de cursos livres de inglês;

- ser representativos desse contexto; e

- representar as qualidades das aulas ou do curso das instituições anunciantes.

O corpus foi composto por vídeos de publicidade no contexto das escolas de cursos livres de inglês por duas razões. A primeira é que as instituições privadas estão mais presentes no discurso midiático do que o serviço público, sendo que, no caso específico do ensino e aprendizagem de inglês, apenas as escolas de cursos livres anunciam cursos de inglês. A segunda razão é que as práticas discursivas associadas ao contexto de escolas de idiomas é, ao mesmo tempo, particular e exemplar.

É um contexto particular no sentido de que o ensino de idiomas (principalmente o inglês) parece ser a única disciplina do currículo regular (de escolas públicas e privadas) que é amplamente ministrada em escolas de cursos livres. Além disso, conforme algumas instituições (MEC, universidades, institutos), os objetivos da "aula de inglês" são radicalmente diferentes na escola regular e na escola livre.

O contexto é exemplar no sentido de que o mercado das escolas de idiomas não apenas é o maior, mas também o que mais cresce entre as escolas de cursos livres, de acordo com a ABF - Associação Brasileira de Franquias (2016). As práticas associadas às escolas de idiomas são muito representativas e, de certa forma, ditam tendências a outras agências educativas da iniciativa privada. A publicidade tão intensiva sobre como o inglês é ensinado (associado a um suposto sucesso) também constitui o discurso sobre a forma como esse ensino acontece ou deveria acontecer

\footnotetext{
${ }^{7}$ Arquivos digitais de vídeo com extensão MP4.
} 
na escola pública e suscita certo desejo (no sentido mercadológico) do curso de inglês idealizado. Frequentemente, às vezes indiretamente, somos acareados com a essa premissa de que o ensino de inglês no ensino regular seria desinteressante e ineficiente e na escola livre seria engajador e eficaz.

Os vídeos foram considerados representativos desse contexto ao serem veiculados em nome de instituições de porte maior que dispõem de mais recursos para uma veiculação de maior abrangência e permeabilidade trasmidiática.

Para o vídeo ser selecionado, deveria haver nele uma representação da qualidade da aula ou do curso anunciado. A análise discursiva nesta tese tem como objeto a formação do discurso da mídia publicitária sobre a sala de aula de língua inglesa em contextos de escolas de cursos livres associada a determinado conceito de interação, o que significa que o curso de inglês é o objeto da mídia, e não a interação ou interatividade. Assim, faz-se necessário apreender o conceito de interação ou interatividade pela representação de como são as aulas nas instituições. Daí buscarmos peças de publicidade que representassem as características das aulas como diferencial, excluindo as que focalizavam branding ${ }^{8}$ e o resultado ou benefício do curso $^{9}$.

Neste ponto é importante apontar que na perspectiva discursiva desta tese, 0 método não é fixo ou anterior à análise, porque a teoria se impõe justamente na medida em que o analista tem um objeto a ser analisado (ORLANDI, 1999). No mesmo sentido, o próprio recorte do corpus é também um exercício de análise. Assim, determinar precisamente o tamanho do corpus ou o volume de textos coletados a priori seria uma impossibilidade teórica. Por isso, coletamos os dados e constituímos o corpus ao longo da pesquisa, inclusive descartando material que posteriormente se mostrou improdutivo. Assim, com o desenvolvimento das reflexões teóricas sobre o discurso da mídia e sobre o chamado fluxo publicitário, ficou evidente que esses recortes não devem ser alinhados em um fluxo ou uma sequência de discursos que iria da produção à recepção. Concluímos que o discurso da mídia publicitária não poderia ser visto como uma cadeia de práticas de produção e de recepção, na qual a mídia estaria em uma das pontas, e a recepção e as discursividades a partir dela

\footnotetext{
${ }^{8}$ Branding é a publicidade que visa à construção da imagem, ao posicionamento e à fixação da marca. A publicidade com esse foco tende a enfatizar a própria marca, não diretamente a aula. ${ }^{9} \mathrm{~A}$ publicidade com esse foco tende a enfatizar o quanto aprender inglês é importante, e não como se aprende.
} 
seriam elos subsequentes dessa pressuposta corrente. Fez-se necessário também, conforme dissemos, compor o corpus também com recortes de outros discursos que constituem o nó de coerções da produção do discurso da mídia publicitária, incluindo comentários escritos de professores de inglês falando sobre interatividade em sala de aula, comentários escritos de consumidores de cursos de inglês, bem como transcrições de interações orais entre profissionais de vendas e prospects (possíveis clientes/consumidores).

Nas entrevistas dos professores, as respostas foram colhidas digitalmente, por meio de formulário online, sem a presença do sujeito-pesquisador. Os entrevistados responderam a duas perguntas: "qual é a melhor forma de se aprender inglês?" e "como deve ser uma aula de inglês?". Esse procedimento teve um baixo grau de seletividade e de controle e pouca ou nenhuma outra intervenção do sujeitopesquisador, que se limitou a propor as perguntas.

A coleta das interações orais entre quem vende e quem compra o curso de inglês e dos comentários dos consumidores de cursos de inglês também foi digital. No primeiro caso, tratam-se de gravações de conversas telefônicas em uma campanha de cliente oculto ${ }^{10}$ em uma rede de escolas de idiomas. No segundo, tratam-se de respostas às mesmas duas perguntas feitas aos professores, também via formulário digital: "qual é a melhor forma de se aprender inglês?" e "como deve ser uma aula de inglês?".

Nos termos de Van Lier (apud NUNAN, 1992: 6-7), que aborda métodos de pesquisa a partir do jogo de intersecções entre os parâmetros de grau de intervenção e de seletividade (conforme ilustra o gráfico), os procedimentos de coleta dos textos publicitários, das respostas dos professores e consumidores, e das interações orais entre vendedor e consumidor correspondem ao espaço "measuring", com alto grau de seletividade e baixo grau de intervenção.

\footnotetext{
10 O "cliente oculto" é uma categoria de pesquisa em que uma espécie de crítico é contratado para se passar por cliente e simular uma situação que o permita avaliar a qualidade dos serviços do estabelecimento ou instituição que o contrata. Frequentemente, os critérios de tal avaliação são determinados também pela instituição que contrata a pesquisa, com objetivo de verificar ou monitorar seus padrões de qualidade.
} 


\section{Figura 1: graus de intervenção e seletividade}

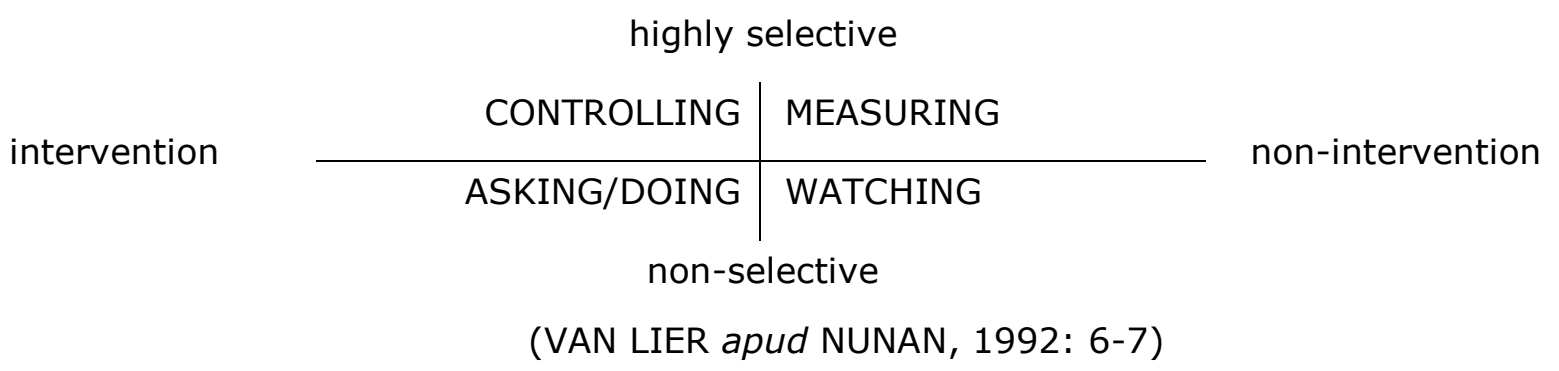

O propósito da análise discursiva dos comentários escritos de professores de inglês e das interações orais de profissionais de vendas com prospects (possíveis clientes/consumidores) é colocar a análise dos textos publicitários em perspectiva e apreender os elementos interdiscursivos sob o argumento de que o discurso da mídia publicitária não se constitui um fluxo de produção discursiva, evidenciando outras articulações entre os nós de coerção da produção desses textos. Constituído dessa forma, o corpus deixa entrever um jogo de forças entre formações discursivas que se articulam em torno dos princípios de regularidade que analisamos. Em outras palavras, os vídeos publicitários anunciando cursos de inglês e muitas vezes representando como é a aula nesses cursos, juntamente com as falas do vendedor, do consumidor e do professor também sobre o curso e a aula de inglês deixam entrever o discurso da mídia sobre a interatividade, entendendo que esse discurso se constitui como um campo problemático ou um nó de forças coercivas entre discursos e não propriamente por um campo discursivo ${ }^{11}$ recortável em sua própria materialidade textual.

\section{Sujeito}

A noção de sujeito em análise de discurso é central. Ela se relaciona com outros conceitos importantes como enunciador, autor e locutor. Conforme Charaudeau e Maingueneau (2004/2008, p. 197):

(...) existe certo número de estatutos ligados à subjetividade: sujeito produtor efetivo do enunciado, sujeito organizador do dizer, sujeito responsável pelo

\footnotetext{
${ }^{11}$ Compreendemos "campo discursivo" conforme Charaudeau e Maingenau (2004, p. 91): "conjunto de formações discursivas (ou de posicionamentos) [que] estão em relação de concorrência no sentido amplo, delimitando-se reciprocamente".
} 
ato de fala, sujeito fonte do ponto de vista, sujeito ponto de origem de ancoragens dêiticas, sujeito oposto a outro sujeito na alteridade fundadora da troca linguística.

Apesar de reconhecermos as especificidades desses estatutos, em nossa análise e reflexão teórica, eles não remetem a instâncias distintas. Ao mesmo tempo, não exatamente agrupamos ou associamos esses estatutos a uma única instância. Fazemos um recorte a partir de uma perspectiva teórica que tem como principal pressuposto que o sujeito é dividido e afetado pela linguagem, pela história e pela ideologia. O sujeito se constitui na problemática da relação de alteridade entre o "Um" e o outro, ou entre o "Eu" e o "Tu". Daí decorre que o sujeito seja descentrado:

Para ela [Análise do discurso], o centro da relação não está nem no "eu", nem no "tu", mas no espaço discursivo criado entre ambos. O sujeito só constrói sua identidade na interação com o outro. $\mathrm{E}$ o espaço dessa interação é o texto. (BRANDÃO, 2004, p. 76)

Nota-se então que essa visão não concebe o sujeito simplesmente como uma estrutura dual, mas sim como algo marcado pela contradição e pela incompletude de forma que o desejo de ser "inteiro" é traço constituinte do sujeito.

Além de descentrado e disperso, o sujeito é também assujeitado pela ideologia. Fora da linguagem não se constitui sujeito. É precisamente a 'entrada' do indivíduo na linguagem que o marca espacial e temporalmente, constituindo o princípio segundo o qual se afirma que sua fala é um recorte de um tempo histórico e espaço social determinados, situando seu discurso em relação aos discursos do outro. O sujeito não é fonte absoluta dos sentidos que produz.

O indivíduo é interpelado em sujeito pela ideologia para que se produza o dizer. Partindo da afirmação de que a ideologia e o inconsciente são estruturas-funcionamentos, Pêcheux diz que sua característica comum é a de dissimular sua existência no interior de seu próprio funcionamento, produzindo um tecido de evidências "subjetivas", entendendo "subjetivas" não como "que afetam o sujeito", mas, mais fortemente, como "nas quais se constitui o sujeito". (ORLANDI, 1999/2009)

Nessa esteira, o sujeito não importa à análise como indivíduo, mas como posição produtora e produto de efeitos de sentido. Para Foucault, sujeito é a posição que o indivíduo pode e deve ocupar para ser sujeito do que diz e objeto do discurso (FOUCAULT, 1969/2009). Nessa perspectiva, o sujeito não tem acesso direto à forma como ocupa ou transforma suas posições, porque estas são constituídas no e pelo interdiscurso. 
Quando falo a partir da posição de "mãe", por exemplo, o que digo deriva seu sentido, em relação a formação discursiva em que estou inscrevendo minhas palavras, de modo equivalente a outras falas que também o fazem da mesma posição. Quando, ao abrir a porta para um filho altas horas da madrugada, a mãe fala "Isso são horas?", ela está, na posição-mãe, falando como as mães falam. Exatamente. Podemos até dizer que não é a mãe falando, é sua posição. Ela aí está sendo dita. E isso a significa. Isso Ihe dá identidade (ORLANDI, 1999/2009, p. 49).

De fato, retomando nossa afirmação da constituição ideológica do sujeito, não é apenas a fala "Isso são horas?" que está associada à posição-mãe. Mas o próprio estar acordada a esperar e o abrir a porta para o filho constituem práticas sociais associadas à posição-mãe. Ou seja, a posição-mãe e qualquer outra posição se inscrevem tanto em formações discursivas como em formações ideológicas. Ao discutirmos a noção de discurso, também abordamos os conceitos de formação discursiva e de formação ideológica.

O sujeito, enfim, é disperso, descentrado, atravessado pela ideologia; entidade que surge da entrada do indivíduo na linguagem - e, portanto, da sua determinação histórica e ideológica - e da divisão consciente/inconsciente. É essa noção de sujeito histórico/psicanalítico que levamos adiante como pressuposto para as reflexões e dispositivos de análise.

\section{Discurso}

Ao presumirmos que a análise de discursiva se constitua como um ponto de vista específico sobre o discurso, este será, evidentemente, um conceito de importância elementar.

O conceito de discurso que usamos nesta tese é difícil de ser simplesmente designado. É preciso contrastá-lo com outros conceitos dos estudos da linguagem para tornear sua definição. Diremos de partida que discurso é um complexo de atos de produção de efeitos de sentido sócio-historicamente determinado. Para tornear essa definição nós a contrastaremos com 'transmissão de informação' e 'fala'.

Discurso não é o mesmo que comunicação em seu sentido tradicional e linear de transmissão de informação. No discurso, não há linearidade entre os elementos da comunicação e na circulação de informação. Não se trata sequer da comunicação entre um "eu" e um "tu" a respeito de um objeto referente que recuperaria a realidade 
na forma de representação. Não é possível, enfim, pensar o discurso como simples troca de mensagens, tampouco um alguém que seja "senhor" ou origem do que diz. Dessa forma, os próprios interlocutores fazem parte do dizer e são ditos pelos lugares/posições que ocupam.

Segundo Orlandi (1999/2009, p. 15), "O discurso é a palavra em movimento, prática de linguagem: com o estudo do discurso se observa o homem falando". Com isso não se deve entender que o discurso coincide com a "fala". Entendido como prática de linguagem sócio-historicamente determinada, se o discurso não se resume à língua, também não se resume a um determinado ato de fala. $O$ discurso também envolve um olhar lançado sobre um texto (qualquer que seja sua modalidade e gênero) do ponto de vista de suas condições de produção. $O$ ato de fala, por exemplo, pode ser abordado como uma enunciação que, por sua vez, constitui uma materialidade a partir da qual o discurso pode ser apreendido.

O discurso, assim, não é produzido ou reproduzido indefinidamente. Há uma ordem do discurso por processos internos e externos (FOUCAULT, 1971/2008). Os processos internos, conforme sugere o nome, funcionam no interior do discurso, classificando e ordenando sua distribuição como forma de regular as dimensões de acontecimento e do acaso do discurso.

Nos termos de Foucault (Idem), o princípio do comentário se refere à limitação de produção de "novos" discursos. Não é possível dizer "qualquer coisa" tampouco dizer sempre pela "primeira vez". Há um desnível entre os discursos que impõe que os dizeres sejam uma repetição de algo já dito, ou seja, podemos dizer algo além do mesmo, mas apenas de forma que esse "mesmo" seja dito e realizado. O comentário limita o acaso do discurso "pelo jogo de uma identidade que teria a forma da repetição e do mesmo" (FOUCAULT, 1971/2008, p. 29).

Outro princípio é o de autoria. Não se trata de algo em torno do indivíduo que fala, mas de um princípio de agrupamento do discurso como aquilo que dá unidade a ele por um recorte. Não é possível dizer qualquer coisa, de qualquer forma. De tudo o que é possível ser dito, o que fará ou não fará parte do que direi? Ou seja, ao dizer algo, necessariamente deixamos de dizer outras coisas. "Pelo jogo de uma identidade que teria a forma da individualidade e do eu" (FOUCAULT, 1971/2008, p. 29).

Ainda segundo Foucault, o princípio da disciplina delimita campos de verdade onde o discurso deve se inscrever. Esse campo projeta regras para a construção de 
discursos em determinada área de conhecimento e sujeitos a "um domínio de objetos, um conjunto de métodos, um corpo de proposições consideradas verdadeiras, um jogo de regras e de definições, de técnicas e de instrumentos" (FOUCAULT, 1971/2008, p. 32).

Os processos externos, conforme sugerem, funcionam no exterior do discurso como imposições sociais à produção de discursos que põem em jogo o desejo e o poder e que funcionam como sistemas de exclusão.

Um desses sistemas de exclusão é nomeado por Foucault como "interdição". Ele define o que pode ser dito e o que é interditado em cada circunstância, seja por tabu do objeto, por imposição do ritual da circunstância ou pelo direito privilegiado de quem fala. Ou seja, a depender do "assunto" sobre o qual se fala, de quem fala e das convenções da circunstância em que se fala, certos discursos são permitidos e outros são interditados. Toda posição do sujeito no discurso necessariamente abre certas possibilidades e interdita outras.

Outro sistema de exclusão é o da separação e rejeição a partir da oposição entre razão e loucura. O discurso do louco não circula como o dos outros porque é tido como nulo; como discurso que não tem verdade nem importância, ou ainda, como discurso que é dotado de poderes especiais, como "o de dizer uma verdade escondida, de prever o futuro, de enxergar com toda ingenuidade aquilo que a sabedoria dos outros não pode perceber" (FOUCAULT, 1971/2008, p. 11).

Finalmente, ainda segundo Foucault (Idem), a vontade de verdade constitui um terceiro sistema de exclusão. Com suportes institucionais, há algo como um jogo de poder de coerção que institui regiões do discurso que determinam o "verdadeiro" ou o "discurso verdadeiro". Dizemos "com suporte institucional" porque as instituições (políticas, religiosas, econômicas, científicas, etc.) exercem pressão sobre a produção discursiva e se posicionam como entidades que legitimam o verdadeiro. Não se trada de discutir "a verdade" (como algo universal ou como lógica interna no interior de um dado discurso), mas sim a arbitrariedade do verdadeiro. A vontade de verdade se organiza em torno de contingências históricas, sustentada por todo um sistema de instituições.

A partir de todo o exposto, é preciso reconhecer que há uma ordem que limita e recorta o discurso, conjurando suas dimensões de acontecimento, de acaso, de desejo e de poder. Ao mesmo tempo, não existe um grande discurso ilimitado que é 
asilado por procedimentos de controle. Os discursos são práticas descontínuas que se repetem, ignoram, excluem e entrelaçam. Nesse sentido, ir do discurso ao seu núcleo interior não é suficiente para compreendê-lo. É preciso partir do próprio discurso para as condições externas de possibilidade, considerando que essas condições de produção do discurso estão inevitavelmente ligadas a um contexto sócio-histórico-cultural específico.

O contexto sócio-histórico-cultural constitui um jogo de coerções para a produção e circulação de discursos. Em tal jogo é possível apreender regularidades em termos de correlações, posições e funcionamentos do discurso. Se tomarmos essas regularidades como "regras" do jogo, elas nos permitem falar em "formação discursiva". Dito de outra forma,

Num caso em que se puder descrever, entre certo número de enunciados,
semelhante sistema de dispersão, e no caso em que entre os objetos, os tipos
de enunciação, os conceitos, as escolhas temáticas, se puder definir uma
regularidade (uma ordem, correlações, posições e funcionamentos,
transformações), diremos, por convenção, que se trata de uma formação
discursiva. (FOUCAULT, 1969/2009, p. 43).

A partir de uma lógica similar, é possível falar em "formação ideológica". Sobre as formações ideológicas, Brandão cita Haroche (1971) para explicar que:

\begin{abstract}
falar-se-á de formação ideológica para caracterizar um elemento (...) susceptível de intervir como uma força confrontada com outras forças na conjuntura ideológica característica de uma formação social em um momento dado; cada formação ideológica constitui assim um conjunto complexo de atitudes e de representações que não são nem "individuais" nem "universais", mas se relacionam mais ou menos diretamente a posições de classe em conflito umas em relação às outras. (BRANDÃO, 2004, p. 47)
\end{abstract}

Neste trabalho, não pretendemos uma diferenciação de formação discursiva e formação ideológica. Muito menos pretendemos ecoar a ideia de que as formações discursivas estão no interior de formações ideológicas. Falamos de uma perspectiva que toma uma pressuposta na outra, não no sentido de serem a mesma coisa, mas no sentido de se implicarem mutuamente. Compreendendo que a palavra é o signo ideológico por excelência (BAKHTIN, 1929/1973), que o discurso é a palavra em movimento (ORLANDI, 1999/2009), e que as atitudes e representações interessam à análise discursiva justamente à medida que significam, nossa perspectiva é a de que a ideologia é constituinte do discurso tanto quanto qualquer prática social só é ideológica porque reclama sentido, o que significa que formações discursivas e 
formações ideológicas se governam mutuamente. Toda produção textual é também produção ideológica, assim como toda produção ideológica reclama sentido.

Dessa forma, quando usamos o termo "formação discursiva", não fazemos referência exclusivamente às contribuições foucaultianas, mas também dialogamos com as contribuições de Bakhtin para o entendimento do signo linguístico como "a" instância ideológica.

A análise conduzida nesta tese se volta para o texto considerado em sua opacidade, ou seja, o texto como algo que não pode ser atravessado rumo aos sentidos corretos ou em favor de uma verdadeira compreensão deles. Não há sentidos por detrás do texto, senão efeitos produzidos pelo discurso e sua materialidade. Assume-se que a análise é interpretativa e que ela deve levar em conta o modo de funcionamento linguístico textual dos discursos e o exercício da língua em um determinado contexto histórico de produção. A Análise de Discurso seria então como um nó, no qual língua, história e sujeito se fazem intrincados (MALDIDIER, 2003). Pouco a pouco e cada vez mais, desde Michel Pêcheux ${ }^{12}$, os estudos discursivos procuram "compreender a língua não só como uma estrutura, mas, sobretudo, como um acontecimento" (ORLANDI, 1999/2009, p. 19).

Dito de modo sobremaneira simples, o discurso é entendido aqui como a prática social de produção de textos, tomando o texto como objeto empírico que impõe certa unidade de sentido, e como sendo a construção sobre a qual se debruça o pesquisador. Isso implica que o discurso é acontecimento social, não ato individual. "O discurso propriamente não é individual. Ele é a manifestação atestada de uma sobredeterminação de toda fala individual (MAZIÈRE, 2005, p. 13)”. O discurso é, portanto, histórico, ideológico e intimamente ligado a uma concepção dialógica da linguagem.

\section{Discurso como sistema aberto}

A afirmação de Deleuze, "a meu ver a linguística não tem nada de essencial" (DELEUZE, 1992/2010, p. 40), será nosso ponto de partida para refletir sobre o

\footnotetext{
12 Atraído pelas questões linguísticas, o filósofo francês é apontado como pioneiro na vertente francesa da Análise do Discurso.
} 
discurso como sistema aberto. Ao fazer essa afirmação e resumir os movimentos de transformação da linguística (de fonológica para sintática e semântica, e então para pragmática), Deleuze retoma a crítica que faz às "constantes abstratas da linguagem" no volume 2 de Mil Platôs. Nesse volume, o filósofo critica aqueles que considerou serem os postulados "essenciais" da linguística, quais sejam (DELEUZE \& GUATTARI, 1995/2011):

(1) A linguagem seria informativa e comunicativa

(2) Haveria uma máquina abstrata da língua, que não recorreria a qualquer [nenhum] fator "extrínseco"

(3) Haveria constantes ou universais da língua que permitiriam defini-la como um sistema homogêneo

(4) Só se poderia estudar cientificamente a língua sob as condições de uma língua maior ou padrão

Para nosso objetivo aqui, vamos nos ater à crítica dos dois primeiros postulados. Ao criticar o primeiro, Deleuze e Guattari apresentam o conceito de "palavras de ordem", entendidas como

\begin{abstract}
a relação de qualquer palavra ou de qualquer enunciado com pressupostos implícitos, ou seja, com atos de fala que se realizam no enunciado, e que podem se realizar apenas nele. As palavras de ordem não remetem, então, somente aos comandos, mas a todos os atos que estão ligados aos enunciados por uma "obrigação social". Não existe enunciado que não apresente esse vínculo, direta ou indiretamente. (...) A linguagem só pode ser definida pelo conjunto das palavras de ordem, pressupostos implícitos ou atos de fala que percorrem uma língua em um dado momento. (DELEUZE \& GUATTARI, 1995/2011, p. 17)
\end{abstract}

Com isso, Deleuze e Guattari refutam a ideia de que a função da língua seja comunicar e informar, e afirmam que sua função é política; é funcionar como agenciamentos coletivos. Sem tal condição, "a linguagem permaneceria como pura virtualidade $^{13 "}$ (DELEUZE \& GUATTARI, 1995/2011, p. 26). São as circunstâncias, os acontecimentos e os atos que ganham importância nos estudos linguísticos e permitem os encontros e causas comuns entre diferentes áreas do conhecimento (DELEUZE, 1992/2010, p. 41).

Essa visão se coaduna com nossa perspectiva discursiva, principalmente por sua interdisciplinaridade e sua condição de linguagem em movimento, de prática de

\footnotetext{
${ }^{13}$ Grifo nosso.
} 
linguagem sócio-histórica; e nossa noção de sujeito, principalmente ao questionar sua unidade e centralidade.

Quanto ao segundo postulado, Deleuze critica a marginalidade do fator "extrínseco" em relação à máquina abstrata da língua. O uso das aspas em "extrínseco" é exatamente para criticar a forma como um estágio intermediário de abstração (ou seja, não suficientemente abstrato) preenche a expressão, confere aos conteúdos o mero estatuto de referência e confina a pragmática a um exterior não linguístico:

\begin{abstract}
Esse sistema [a forma de expressão como sistema linguístico] pode ser concebido como estrutura fonológica significante, ou como estrutura sintática profunda. Teria, de todo modo, a virtude de engendrar a semântica, e de preencher assim a expressão, ao passo que os conteúdos seriam entregues ao arbitrário de uma simples referência, e a pragmática, à exterioridade dos fatores não linguísticos (...), constituindo essa máquina como um conjunto sincrônico de constantes. (DELEUZE \& GUATTARI, 1995/2011, p. 34)
\end{abstract}

Deleuze insiste que os fatores não linguísticos constituem, na verdade, uma pragmática interna e inseparável da linguística. O filósofo não questiona a existência de uma máquina abstrata. Ao contrário, afirma que ela não é abstrata o suficiente e que é preciso impulsionar sua abstração para outro nível para destituir sua linearidade, conforme é tradicionalmente concebida, substituindo as pseudoconstantes da língua pelas variáveis de expressão, que são interiores à própria enunciação, e se definindo como as linhas de encontro de agenciamentos ${ }^{14}$. "A máquina abstrata enquanto relacionada ao diagrama do agenciamento nunca é linguagem pura, exceto por erro de abstração" (DELEUZE \& GUATTARI, 1995/2011, p. 35).

Uma das implicações dessa perspectiva deleuziana, a de que "o conteúdo não é um significado nem a expressão é um significante, mas ambos são as variáveis do agenciamento" (DELEUZE \& GUATTARI, 1995/2011, p. 35), se coaduna com nossa perspectiva discursiva, principalmente ao concebermos o discurso como prática social ideológica e ao compreender que o discurso está sujeito há uma ordem.

Há ainda uma segunda implicação, a qual levamos em conta para constituição de nosso dispositivo de análise discursiva. A crítica da máquina abstrata da linguística tradicional por ela estar ligada a um modelo arborescente e à ordem linear dos

\footnotetext{
${ }^{14}$ Para Deleuze, o agenciamento tem dois eixos. O eixo horizontal é formado pelo encontro de corpos que reagem uns aos outros, produzindo estados de coisas, e pelo jogo de mútuas intervenções de acontecimentos, produzindo transformações incorpóreas que se atribuem aos corpos. No eixo vertical, o agenciamento tem lados de reterritorialização e picos de desterritorialização (linhas de fuga).
} 
elementos linguísticos, atribuindo ao conteúdo e à expressão o estatuto de variáveis, estabelecendo o discurso como sistema rizomático, no qual o sujeito, tanto quanto o sentido, é da ordem do acontecimento.

Analisemos os elementos dessa implicação. Primeiramente o rizomático. Dizer que o discurso é rizomático é afirmar que ele é constitutivamente heterogêneo, de tecido descontínuo e sem pontas, com uma lógica de conexão que escapa a qualquer modelo gerativo ou estrutural linear. Para Deleuze,

"Diferentemente das árvores ou de suas raízes, o rizoma conecta um ponto qualquer com outro ponto qualquer, e cada um de seus traços não remete necessariamente a traços de mesma natureza, ele põe em jogo regimes de signos muito diferentes, inclusive estados de não-signos. O rizoma não se deixa reduzir nem ao Uno nem ao múltiplo. (...) Ele não é feito de unidades, mas de dimensões, ou antes, de direções movediças. Não tem começo nem fim, mas sempre um meio, pelo qual ele cresce e transborda". (DELEUZE \& GUATTARI, 1995, p. 43)

Esse conceito pode ser articulado com nossa perspectiva discursiva, já que abordamos o discurso também por suas regularidades, descontinuidades e suas dimensões de acontecimento e do acaso (FOUCAULT, 1971/2008).

Dizer que o sujeito é da ordem do acontecimento significa que ele não é selecionável, nem dado a priori e se constitui como um problema que se resolve em um aqui e agora. Essa concepção pode ser trabalhada na esteira do princípio segundo o qual o sujeito se constitui no e pelo interdiscurso.

Além desses traços de articulação e coadunação, dessa perspectiva deleuziana construímos um potencial de análise do nosso corpus. Argumentamos que o discurso da mídia é entre-discursos, traços rizomáticos em uma dimensão que não conecta um ponto qualquer com outro ponto qualquer sem fazer operar linhas de fuga $^{15}$. Esse discurso constitui um sistema de dispersão que mobiliza, reitera, cria, silencia, sedimenta e retoma sentidos de outros discursos.

Em grande medida, abordamos esses traços pelo viés da heterogeneidade constitutiva do discurso e da interdiscursividade ${ }^{16}$. Conforme afirma Carmagnani,

\footnotetext{
${ }^{15}$ Linha de fuga é o traço rizomático que desterritorializa e implica uma reterritorialização e que, em nossa reflexão teórica, corresponde ao eixo vertical da uma máquina abstrata da língua. (DELEUZE \& GUATTARI, 1995)

16 Interdiscurso é compreendido como o conjunto estruturado das formações discursivas em que se constituem os objetos e as relações que o sujeito assume, de forma que cada formação discursiva dissimula, "na transparência do sentido que aí se forma, (...) o fato de que "isto fala" sempre antes, alhures ou independentemente" (PÊCHEUX, 1975/1993, p. 147).
} 
(...) é a relação interdiscursiva que estrutura a identidade dos vários discursos, isto é, não há um discurso puro, essencialmente político, religioso, publicitário, ou científico (...). Essa divisão [de diferentes discursos] (...) não deveria sugerir a possibilidade de estabelecimento de limites rígidos. (CARMAGNANI, 1996, p. 90)

A análise nessa esteira nos permite compreender o modo de funcionamento do discurso da mídia levando em conta sua relação com outras formações discursivas. Porém, há algo de específico na relação interdiscursiva que constitui o discurso da mídia publicitária, e podemos abordar tal especificidade a partir do conceito de diferencial ${ }^{17}$ deleuziano. Assim conseguimos compreender a interdiscursividade não apenas como abstração que estrutura, determina ou se manifesta, a partir da qual o discurso "faz sentido", mas como abstração diferençada. Abordamos a interdiscursividade não exatamente como constituinte da enunciação em relação de determinação (mesmo que não determinística), mas como uma individuação que produz diferenciação. Ao invés de tomar o interdiscurso e a enunciação como gênese do abstrato ao possível e existente, compreendemos que o interdiscurso seja um campo de diferençação que resolve suas disparidades latentes e problemáticas, e a enunciação como diferenciação ${ }^{18}$, ou seja, como diferenças atuais pelas quais as diferenças virtuais tomam a forma de acontecimentos diferençados. Tomamos assim o interdiscurso como uma abstração que não é apenas heterogênea e descontínua, e que não constitui um passado propriamente, mas que é uma operação de síntese do tempo ${ }^{19}$ que constitui uma latência discursiva no aqui e agora, e que fica sujeita às relações que o enunciado pressupõe e estabelece no ato mesmo de ser enunciado.

Evidentemente, não se deve ver aí nenhuma forma de subversão ou revisão do conceito de interdiscurso. Ao contrário, essa perspectiva deleuziana apenas contribui para que levemos a cabo o pressuposto de que a historicidade do discurso não significa uma temporalidade linear e segmentar. Essa perspectiva é fundamental nesta tese, principalmente na análise da formação discursiva da mídia publicitária,

\footnotetext{
17 Diferencial. Deleuze subverte a relação solução-problema, no sentido de que, para ele, "a Matemática não compreende apenas soluções de problemas; ela compreende a expressão dos problemas" (DELEUZE, 1988/2006, p. 256). A subversão consiste em uma inversão: "em vez de procurar, como que ao acaso, se uma equação é resolúvel em geral, é preciso determinar condições de problemas que especifiquem progressivamente campos de resolubilidade, de tal modo que ' 0 enunciado contenha o germe da solução"' (DELEUZE, 1988/2006, p. 257).

18 Distinção feita conforme o glossário da edição brasileira de "Diferença e Repetição" de Deleuze: "différentiation" equilave a "diferençação", e "différenciation" a "diferenciação".

19 Usamos o termo conforme Deleuze (1988/2006), ao descrever as três sínteses do tempo.
} 
porque permite reconhecer as insuficiências da abordagem arqueológica das regras de formação descritas por Foucault, e propor alternativas de reflexão ao analisar a formação do conceito de interação nesse discurso. A relação interdiscursiva do discurso da mídia publicitária é elevada à potência e, com esse olhar, podemos abordar as relações entre formações discursivas e analisar as regras de formação do discurso da mídia publicitária, buscando entrever as condições dos nós coercivos do funcionamento desse discurso e do interdiscurso.

\section{Conclusões}

Nesta tese, em grande medida, os procedimentos metodológicos e a perspectiva teórica discursiva se confundem, por implicação da própria teoria. A discussão dos conceitos de sujeito e de discurso se lança sobre uma reflexão do discurso como sistema aberto, conforme descrevemos; isso foi determinante sobre os recortes que compuseram o corpus que, ao longo da pesquisa, foi feito, desfeito e refeito algumas vezes. A constituição do corpus, em si, é já resultado de reflexão teórica e análise discursiva. Além disso, as contribuições de Deleuze e Guattari (1992/2010; 1995/2011) são retomadas também em outras reflexões teóricas e momentos de análise do corpus constituído. 


\section{Capítulo 2}

\section{CONTEXTO SÓCIO-HISTÓRICO E SEUS NÓS DE COERÇÃO}

O objetivo deste capítulo é refletir sobre o contexto sócio-histórico do discurso da mídia publicitária sobre a sala de aula de inglês em escolas de cursos livres e suas representações de interação. Discutiremos as ideias pedagógicas predominantes em nosso tempo (SAVIANI, 2007/2010), fazendo relações com (1) os fatores envolvidos na constituição do discurso verdadeiro (FOUCAULT, 1971/2008) e com (2) aquilo que, em uma sociedade do espetáculo (DEBORD, 1997/2013), é estabelecido ou desejado para ser consumido.

\section{Neoescolanovismo, neoprodutivismo e neotecnicismo}

Atualmente, é amplamente apregoada a ideia de que o aluno deve estar envolvido emocionalmente para aprender e o ato de aprender deve ser divertido, prazeroso e significativo. Não apenas no corpus desta tese, podemos notar manifestações dessa ideia no discurso midiático relacionada ao ensino e 
aprendizagem. Quantas vezes vimos anúncios de escolas que dizem algo como "aqui você aprende brincando", "aqui você aprende sem sofrimento", ou "você nem percebe e já aprende", ou ainda "aqui você aprende de um jeito fácil"? Nesses mesmos anúncios, contrasta-se a imagem do ensino dito tradicional, onde aprender seria chato e penoso, com a imagem de alunos felizes e motivados estudando na escola anunciada.

Consideremos a sala de aula nos meados da década de 1970. Apesar de outras correntes (concepção analítica e visão critico-reprodutivista) coexistirem e competirem, nessa época a pedagogia tecnicista foi dominante (SAVIANI, 2007/2010). A concepção da pedagogia tecnicista é baseada no pressuposto da neutralidade científica e exalta os princípios da racionalidade, eficiência e produtividade. Pretendiase a objetivação do trabalho pedagógico com uma lógica fabril nos moldes fordistataylorista. De acordo com essa visão, é preciso normatizar as ações dos indivíduos envolvidos no processo de modo a garantir os resultados, de maneira análoga à modernização dos meios de produção que elimina a subjetividade do trabalhador, o que garantiria a uniformidade e o padrão de qualidade do produto. Ou seja, há um foco no processo que envolve os indivíduos e não no processo de cada indivíduo. De acordo com Saviani (2007/2010), na pedagogia tecnicista o elemento principal é

\begin{abstract}
a organização racional dos meios, ocupando o professor e o aluno posição secundária, relegados que são à condição de executores de um processo cuja concepção, planejamento, coordenação e controle ficam a cargo de especialistas supostamente habilitados, neutros, objetivos, imparciais. A organização do processo converte-se na garantia da eficiência, compensando e corrigindo as deficiências do professor e maximizando os efeitos de sua intervenção. (SAVIANI, 2007/2010, p. 382)
\end{abstract}

É interessante reparar que nada nessa descrição parece contemplar questões afetivas. O aluno tinha um papel a cumprir no processo tal qual um trabalhador em uma linha de produção. Se ele fizesse o que o processo determinava, resultados satisfatórios seriam obtidos. A mesma lógica também se aplicava ao professor, que passou de co-criador do processo ${ }^{20}$ a mero executor.

Nesse cenário, a aula não precisava ser "legal"; o professor não precisava motivar; conhecimento e informação se confundiam; os assuntos tratados eram

\footnotetext{
${ }^{20}$ Saviani contrasta a pedagogia tecnicista com a 'tradicional', na qual o processor tinha a responsabilidade da iniciativa, no sentido de ser, ao mesmo tempo, o sujeito do processo, elemento decisivo e decisório (SAVIANI, 2007/2010, p. 382). Para Saviani, a pedagogia 'tradicional' foi predominante até a década de 20 e competiu tal predominância com a pedagogia da chamada Escola Nova na década de 30 .
} 
supostamente iguais para todos e não existia a preocupação generalizada em trazer ou tornar os tópicos "significativos" para os alunos. A sala de aula era lugar de trabalho "sério", em um processo linear, padrão e sem desvios.

O tecnicismo inicia uma fase de declínio a partir da crise mundial que provoca alguns deslocamentos na lógica capitalista na década de 1970, levando a uma reorganização dos modelos de produção. O modelo fordista-taylorista, que previa a produção em larga escala de produtos estandardizados para consumo em massa, acaba fragilizado em um mundo com processo de globalização mais acelerado e em uma realidade mais líquida, volátil e descentrada, principalmente a partir do desenvolvimento da internet e das tecnologias da comunicação. O trabalhador, por exemplo, que outrora tinha estabilidade no emprego, passa a ter que disputar continuamente sua posição. O que "devia ser feito" era fixo. A partir dos anos 90, o mundo passa a ser percebido como fragmentado, descentrado e fluído, nos termos de Hall (2006).

Esse é um cenário com todas as condições para a emergência do modelo toyotista (neoprodutivista). Ele se contrasta com a lógica fordista-taylorista em vários sentidos:

- Ao invés de uma base tecnológica pesada e fixa, base tecnológica leve e móvel, que prevê flexibilidade.

- Ao invés de massificação, produção de artigos diversificados que atendam nichos específicos.

- O foco na demanda coletiva muda para a demanda individual.

- Graças à implementação de sistemas como o just in time, têm fim os grandes estoques.

- Trabalhadores especializados no que fazem e de posições estáveis dão lugar a trabalhadores polivalentes que "vistam a camisa" da empresa e mantenham-se constantemente atualizados.

Em sua síntese sobre as ideias pedagógicas no Brasil, Saviani (2007/2010) descreve eventos históricos e modos de organização dos sistemas econômicos e correntes pedagógicas mais ou menos hegemônicas e contra-hegemônicas em determinados períodos da nossa história. De todo o percurso feito por Saviani, 
interessa aqui justamente esse recorte a partir da década de 90, quando 0 desenvolvimento da internet e das tecnologias da comunicação parecem ter intensificado os traços da conjuntura que possibilita e condiciona os discursos em análise nesta tese.

Conforme discutimos, em resposta ao modelo de produção fordista em declínio, ganha proeminência um modelo - o toyotismo - segundo o qual é preciso produzir (a) somente o necessário (flexibilização da produção), reduzindo ou eliminando estoques, (b) com a máxima qualidade e (c) privilegiando a diversificação sobre a padronização.

Sobre a produção apenas daquilo que é "necessário", o objetivo é eliminar gargalos na produção e custos no estoque de excedentes. Ou seja, é preciso flexibilizar a produção para produzir apenas o necessário em um dado momento (just in time), identificando a demanda imediata (ou até mesmo produzindo apenas após a venda) para reduzir os estoques ao mínimo. Para que isso funcione, há investimento na autonomia dos trabalhadores em seus postos de trabalho e no trabalho em equipe como forma de agilizar a tomada de decisão, diminuir gargalos e eliminar o tempo ocioso.

Com relação à máxima qualidade, trata-se de uma orientação ao consumidor. Com ações orientadas por prioridades e por controle e investigação de processos, cada trabalhador ganha a responsabilidade sobre a satisfação completa do consumidor no sentido de que a qualidade de seu trabalho interfere na qualidade do produto na próxima etapa do processo. Além disso, a questão da autonomia também é central. Permitir que haja uma pessoa responsável por cada uma das etapas específicas do processo e um superior que toma as decisões dificulta o trabalho de controle de qualidade porque remete a uma supervisão sobre o processo ou, ainda, sobre cada etapa do processo. No toyotismo, todos e cada um dos trabalhadores são responsáveis pela qualidade do produto, em todas as etapas da produção e têm autonomia para agir quando identificam um erro ou algo a ser melhorado. Nesse sentido, o trabalhador deve ser mais qualificado, proativo, motivado, participativo e polivalente, flexível ou versátil.

Quanto à ênfase na diversificação em detrimento da padronização, há uma relação direta com a "qualidade total". A máxima atribuída a Henry Ford, "o carro é disponível em qualquer cor, contanto que seja preto", já não pode ser aplicada. Ao 
contrário, é preciso identificar as verdadeiras necessidades e desejos dos consumidores para vender mais e melhor. Dessa identificação surge a demanda por uma diversidade de características e não algo padrão, para que o consumidor possa escolher.

No conjunto desses três aspectos, just in time, qualidade total e diversificação, também ficam implicadas as ideias de individualismo, eficiência, eficácia, produtividade, captura da subjetividade ("vestir a camisa da empresa"), autonomia, descentralização, globalização e outras que constituem o discurso neoliberal.

Nossa reflexão sobre as representações de "interação" na sala de aula, ou sobre a sala de aula em sentido mais geral, leva em conta esses aspectos que, a princípio, são mais especificamente relacionadas às práticas sociais do trabalho produtivo na sociedade capitalista neoliberal. No entanto, esses aspectos também constituem as práticas pedagógicas e as representações sobre a sala de aula. Em grande medida, as três correntes hegemônicas de ideias pedagógicas no Brasil neoescolanovismo, neoprodutivismo e neotecnicismo - são responsivas às coerções neoliberais.

No neoescolanovismo, em nome de uma formação que deve ser desenvolvida ao longo da vida para responder aos desafios de uma realidade social em rápida e constante transformação, o mais importante não é ensinar, nem mesmo aprender. $O$ mais importante é "aprender a aprender" (SAVIANI, 2007/2010). Na sala de aula escolanovista, o professor não deve necessariamente ensinar, mas ajudar o aluno em seu próprio processo de aprendizagem. Nesse ponto, já é possível apontar os valores da individualização, da flexibilização e adaptação ("seu próprio aprendizado"), além da atuação do professor voltada ao aluno, assim como a do trabalhador é voltada ao consumidor. Se de acordo com outras correntes seria preciso que o aluno se esforçasse para aprender, aqui é preciso que ele tenha vontade, ou seja, que seja engajado em práticas de sala de aula para aprender coisas de seu interesse. Nessa sala de aula, a disciplina rigorosa perde espaço para a espontaneidade. É preciso que a atmosfera da sala de aula seja estimulante e engajadora. Em meados da década de 1990, o relatório Jacques Delors ${ }^{21}$ trazia orientações gerais para a educação mundial no século XXI e, entre elas, defendia que a escola deveria transmitir o gosto e o prazer de aprender, além de promover a curiosidade intelectual. Nesse sentido, o

21 Publicado pela UNESCO em 1996. 
escolanovismo valoriza os processos de convivência, os relacionamentos, a afetividade, a motivação do aluno para aprender e a necessidade de atualização constante. Esses traços, principalmente este último, estão também relacionados ao princípio neoliberal da extrema competição pelo emprego e a adaptação às demandas do mercado.

O neoconstrutivismo tem muita afinidade com o neoescolanovismo em relação ao aprender a aprender, já que defende uma "pedagogia das competências" (SAVIANI, 2007/2010), a qual pretende desenvolver nos indivíduos comportamentos flexíveis, competências em um sentido que se aproxima da ideia de mecanismos adaptativos do comportamento humano ao seu meio, como maneira de formar indivíduos capazes de se adaptar às condições que a realidade lhes impuser. Nesse sentido, a "sobrevivência" do aluno no mercado dependeria de sua iniciativa e aptidão individuais.

O neotecnicismo, segundo Saviani (2007/2010), acomoda essas características do neoescolanovismo e do neoconstrutivismo e torna-se uma corrente predominante em nosso tempo porque melhor responde ao modelo de produção toyotista. Ou seja, o neotecnicismo é fortemente influenciado por ideias neoliberais, que têm na captura da subjetividade dos indivíduos um de seus principais pilares. Silva (1994/2012) explica que

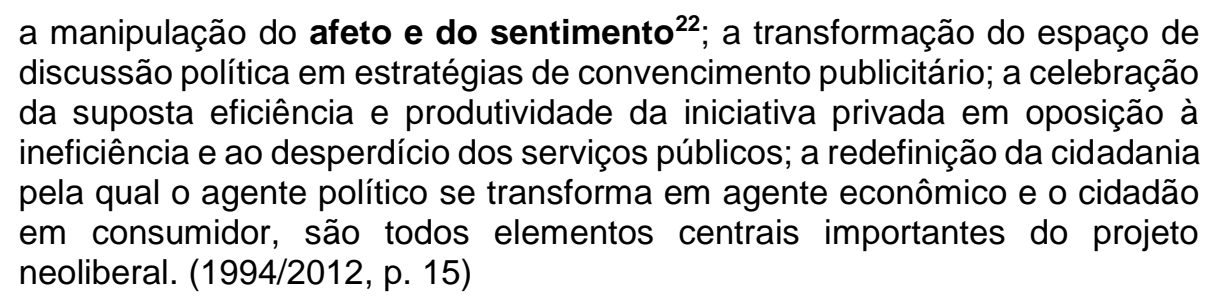

No neoprodutivismo, a captura da subjetividade do trabalhador se manifesta em expressões como "vestir a camisa" da empresa; o mercado exige um indivíduo que se envolva com a empresa em um nível afetivo. O discurso de maior penetração não exatamente afirma que se deve fazer aquilo em que se é bom, aquilo em que se tem talento; tem mais força a afirmação de que é preciso fazer o que se "gosta".

A sala de aula, como lugar em que as pessoas são obrigadas a estar, não é mais atrativa. A lógica neoliberal atribui à sala de aula a obrigação de ter essa

\footnotetext{
22 Grifo nosso.
} 
qualidade. Nessa lógica, é preciso querer e gostar de estar em sala de aula. Os princípios neoliberais nutrem uma cultura de entretenimento e apelo à afetividade em várias instâncias do nosso modo de vida, inclusive na sala de aula.

A mídia também tem um papel nessa conjuntura, no sentido de que "o entretenimento é o principal produto oferecido pela cultura da mídia, que espetaculariza o cotidiano de modo a seduzir suas audiências e levá-las a se identificarem com as representações sociais e ideológicas nela presentes" (CASTRO \& ROCHA, 2009, p. 50).

$\mathrm{Na}$ concepção da pedagogia neotecnicista, projeta-se a representação do professor motivador e toma como pressuposto que a motivação do aluno para os estudos é um fator de grande importância para o êxito escolar.

Evidentemente, os princípios neoliberais exercem influência não apenas sobre a sala de aula, mas também sobre vários outros pontos da complexa teia de relações do nosso modo de vida. Responsivos ao mesmo jogo de forças, muitos preferem ir a um supermercado que é "lugar de gente feliz"; matricular-se em uma escola de inglês onde "você nem percebe e, quando vê, já está falando"; frequentar uma escola onde "você gosta, você aprende"; participar de uma aula 'interativa', ou fazer um curso motivacional.

Uma aprendizagem que exija trabalho duro, insistência e seriedade, repleto de falhas e obstáculos a serem superados é indesejável para a sala de aula em um cenário em que o aluno precisa ter vontade para melhor aprender. Nossa sala de aula faz parte de uma teia de relações que tem grande influência de ideias neoliberais e uma lógica de mercado que insiste na espetacularização (DEBORD, 1997/2013) e nos traços de entretenimento, entre outras coisas.

Aquela sala de aula em que a "disciplina" era uma palavra-chave dá lugar a outra que tem "motivação" como uma das ideias centrais. A imagem estereotípica sobre aquela sala de aula remete a questões como o controle do comportamento e o aluno como aquele que "deve" estudar; deve prestar atenção. Nesta sala de aula, nos deparamos com forças conjuntivas que apontam para a flexibilidade do processo e tomam o aluno como aquele que deve ser motivado e envolvido para "querer" estudar e prestar atenção. Cada vez mais, inclusive pelo apelo midiático, "a procura de "soluções mágicas" do tipo [...] relações prazerosas e pedagogia do afeto [...] e 
fórmulas semelhantes vem ganhando a cabeça dos professores" (SAVIANI, 2007/2010, p. 449).

Nos anos 90, ainda em meio à predominância do tecnicismo, Luiz Carlos de Freitas se pergunta: "Conseguiremos escapar ao neotecnicismo?" Saviani (2007/2010) responde a essa pergunta dizendo que "não, não conseguimos" (p. 428).

Não podemos perder de vista que, apesar de apresentar diferenças substanciais, o neotecnicismo conserva os princípios centrais do tecnicismo, que são embebidos nos princípios neoliberais. Ou seja, a questão do engajamento afetivo, que concorre para que muitos idealizem a sala de aula como lugar de entretenimento, é acompanhada das ideias de "qualidade total", modernização da escola, adequação do ensino à competitividade do mercado internacional, incorporação das técnicas e linguagens das tecnologias da comunicação, universidades corporativas, abertura da universidade aos financiamentos empresariais, produtividade e pesquisas práticas e utilitárias e da pedagogia corporativa ${ }^{23}$.

Se por um lado, "a qualidade da escola [regular] é condição essencial de inclusão e democratização das oportunidades no Brasil” (BRASIL, 2006), por outro, a "pedagogia corporativa" se dissemina no Brasil com o beneplácito da própria política educacional (SAVIANI, 2007/2010). O fato de haver agências educacionais na iniciativa privada, inclusive em empresas de outros ramos de atuação que não propriamente o da educação, a linguagem da mídia encontra mais espaço e propriedade para permear de forma cada vez mais acentuada os discursos sobre a sala de aula.

Pode-se dizer que a sala de aula de hoje não rompe com a sala de aula de ontem. Em nossa sociedade, a lógica neoliberal exerce grande influência sobre nosso modo de vida e concorre para comoditizar, reificar, coisificar todos os seus aspectos, inclusive a sala de aula. A sala de aula, como produto veiculado na mídia é mais atraente se for, por exemplo, divertida e interativa.

Em contrapartida, esses "novos" traços idealizados para a sala de aula são apenas alguns elementos que deixam entrever o nosso momento histórico marcado pelo descentramento e desconstrução de ideias pedagógicas anteriores. Na época em que vivemos não há um núcleo ou um conjunto de elementos que possa resumir,

${ }^{23}$ Tem início um movimento no qual as empresas provadas tomam para si a corresponsabilidade pela formação da sua própria força de trabalho. 
definir ou representar as ideias sobre a sala de aula. Essa dificuldade parece nos forçar a definir nossa sala de aula de agora sempre em relação à "outra"; em relação a algo anterior. Talvez isso explique a recorrência com que os textos da mídia publicitária anunciam, como forma de defini-la, que a sala de aula de hoje se distancia da sala de aula tradicional.

Ao falar "sala de aula hoje", às vezes implícita, mas muitas vezes explicitamente, esses textos midiáticos expressam a ideia de uma sala de aula supostamente anterior: que não desejamos mais ou que já teria deixado de existir. Ao descrever a sala de aula de "hoje", os traços neoprodutivistas vêm à tona: dinâmica, interativa, produtiva, eficiente, divertida, acolhedora, educacional, etc. Essas representações são apresentadas naturalizadas, normalizadas, como se assim devessem ser de fato, contrastando apenas com o que é chamado de sala de aula tradicional. Ela, a sala de aula dita tradicional, acaba ganhando, nesses textos midiáticos publicitários, os adjetivos antagônicos e mais próximos dos pontos em que houve deslocamentos na corrente tecnicista: desinteressante, passiva, reprodutiva, controladora, conteudista. Ou seja, nossa sala de aula não é idealizada como motivadora e divertida simplesmente por uma espécie de "evolução natural"' das ideias pedagógicas. Essa idealização é parte de uma conjuntura mais ampla, na qual a educação, institucionalmente e pragmaticamente, é influenciada por modelos empresariais de gestão ("qualidade total") e formações ideológicas neoliberais. A sala de aula é alvo do movimento de comoditização neoliberal e tais traços fazem dela uma mercadoria de maior valor.

\section{Sala de aula espetacular e sua espetacularização}

Por me ostentar assim, tão orgulhoso de ser não eu, mas artigo industrial, peço que meu nome retifiquem. Já não me convém o título de homem. Meu nome novo é coisa. Eu sou a coisa, coisamente. 
Dizer que a sala de aula é um espetáculo talvez seja menos preciso do que dizer que a sala de aula é um espaço de espetacularização no qual o aluno é consumidor e produto. O aluno não é apenas o consumidor-espectador das representações espetaculares da sala de aula, mas também é o próprio produto que esse espaço oferece ao mercado neoliberal.

Refletir sobre a "sociedade do espetáculo" (DEBORD, 1997/2013), focalizando o papel da mídia na produção e circulação de sentidos em uma sociedade como a nossa, suscita a crítica à visão de que o espetáculo é a expressão máxima do processo de alienação em que "tudo o que era vivido diretamente tornou-se uma representação24” (DEBORD, 1997/2013, p. 13). Se o espetáculo serve ao mercado como movimento autônomo do não vivo, e "é ao mesmo tempo resultado e o projeto do modo de produção existente" (DEBORD, 1997/2013, p. 14), não pode envolver simplesmente um processo de alienação. De fato, a redução da vida humana e social à simples aparência, que é mediada pela mídia, é parte do movimento de espetacularização que reifica tudo e todos para o consumo do mercado. Porém, ao mesmo tempo, parte do movimento de espetacularização se coaduna com a reconversão produtiva promovida pelo toyotismo e, em nome da "qualidade total", precisa produzir para si sujeitos engajados:

Aplica-se uma característica inerente ao modelo toytista que o diferencia do fordismo: capturar, para o capital, a subjetividade dos trabalhadores. Nessa dimensão, "qualidade total" significa conduzir os trabalhadores a vesrir a camisa da empresa. (SAVIANI, 2007/2010, p. 440)

Essa captura da subjetividade é mediada pela mídia na parte que lhe cabe na ordenação e organização do espaço social, sendo esse um dos aspectos que respondem ao fato de nossa atenção para a mídia ser mais que casual, talvez até necessária, e da mídia parecer ocupar um lugar essencial nas nossas vidas conjuntas, como seres sociais (COULDRY, 2003, p. 1). O poder dos recursos de comunicação permeia de forma cada vez mais acentuada os modos de construção de sentido nas sociedades atuais e a formação e negociação das subjetividades estão intimamente associadas a esse fenômeno. Além disso, os próprios meios de produção culturais

\footnotetext{
24 Deve-se entender "representação" como uma intermediação que distancia o sujeito de sua própria experiência no sentido de que não importa o "ser" dessa experiência e sim o que ela "parece ser", e não exatamente como compreendido nos estudos discursivos. A tradução para o inglês parece ser mais precisa, nesse sentido, porque usa a palavra "proxy", que significa procuração, ao traduzir "tout ce qui était directement vécu s'est éloigné dans une représentation" para "things that were once directly lived are now lived by proxy".
} 
são midiatizados e consumidos. Algo pode ser "produto" (um valor a ser consumido) e ao mesmo tempo ser veículo de midiatização de outros produtos e práticas de consumo. Por uma lógica similar, a sala de aula é ela própria um espetáculo e ao mesmo tempo um movimento de espetacularização porque seus alunos também são coisas, são mercadorias que disputam entre si um lugar no mercado.

Os valores neoliberais podem ser considerados dominantes em nossa sociedade e, não coincidentemente, são os mais associados à internet e cibercultura em geral. O individualismo, a qualidade total, a busca pelo "progresso", a flexibilidade, a adaptabilidade, o entretenimento e a multiplicidade são ideais neoliberais. Numa sociedade como a nossa, tais ideais são como qualidades transformadas em produtos (culturais), principalmente ao serem midiatizados. As qualidades associadas à ideia romantizada e esterilizada de interação estão em relação com ideais neoliberais e são os produtos com tais qualidades que o aluno-consumidor-espectador consome. $O$ aluno consome a sala de aula espetacular.

Ao mesmo tempo o aluno é produto para o mercado e, portanto, objeto de espetacularização por vontade própria ou senso de pertença em uma suposta ordem social. De acordo com Saviani,

\begin{abstract}
Manifestou-se a tendência a considerar aqueles que ensinam como prestadores de serviço, os que aprendem como clientes, e a educação como produto que pode ser produzido com qualidade variável. No entanto, sob a égide da qualidade total, o verdadeiro cliente das escolas é a empresa ou a sociedade, e os alunos são os produtos que os estabelecimentos de ensino fornecem a seus clientes. (SAVIANI, 2007/2010, p. 440)
\end{abstract}

Como coisa, como produto, o aluno também deve ter as qualidades que dele se espera para que possa ter maior valor no mercado, alavancado pela lógica da competição neoliberal. Na espetacularização difusa que opera em nossa sociedade, os diferentes produtos conflitam e limitam-se, competindo pelo espectador por meio da sedução mais do que pela violência, sendo que "cada mercadoria considerada separadamente é justificada em nome da grandeza da produção da totalidade dos objetos, cujo espetáculo é um catálogo apologético" (DEBORD, 1997/2013, p. 43). O anúncio de uma determinada escola de inglês não tem como espectador apenas o aluno. Ao anunciar seu curso, a instituição de ensino anuncia para o mercado os alunos que produz, conforme as qualidades que o mercado diz que o produto deve ter. O mercado consome o aluno espetacular. 
Atender a esse duplo movimento de espetacularização é uma condição para a entrada no discurso da mídia publicitária, que, por sua vez, longe de ser apenas uma intermediária do espetáculo, é ela própria um espaço de espetacularização. Se à primeira vista é sobretudo o indivíduo que a mídia publicitária pretende seduzir, em última instância é o mercado a quem ela deve seduzir para operar.

Ao abordar a sala de aula como "espetacularização" e não apenas como espetáculo, tornamos possível apreender o encontro de corpos e a irrupção e intervenção de acontecimentos no estabelecimento da conjuntura que analisamos adiante, e que o estado das coisas e os acontecimentos se reportam à uma lógica que os reconvertem em nós de coerções de transformações. Assim evitamos a armadilha de se poder abordar a sala de aula apenas como um espetáculo veiculado e que procura seduzir o indivíduo, e abrimos a possibilidade de analisar as representações da sala de aula como veículações que não apenas são responsivas ao mercado, mas que também querem seduzí-lo. Além disso, abordamos a questão do "espetáculo" sem permitir que se desenhe um cenário determinístico (ênfase nas constantes) e deixando entrever as variáveis da espetacularização como condições e produtos de discursos.

\section{O discurso verdadeiro no contexto de ensino livre de inglês}

Em "A ordem do discurso", Foucault (1971/2008) discorre sobre procedimentos internos e externos ao discurso para seu controle, rarefação e ordenação. Os procedimentos externos de sujeição do discurso são tomados na análise do corpus e, aqui, nos interessa tratar especificamente de um procedimento interno: a vontade de verdade.

De acordo com Foucault, a vontade de verdade é um sistema de exclusão que se apoia em suportes institucionais:

É ao mesmo tempo reforçada e reconduzida por todo um compacto conjunto de práticas como a pedagogia, é claro, como o sistema dos livros, da edição, das bibliotecas, como a sociedades de sábios outrora, os laboratórios hoje. (FOUCAULT, 1971/2008, p. 17)

Diante desta afirmação, poder-se-ia concluir, desavisadamente que a generalizada valorização da interação para a aprendizagem se apoia nas teorias 
construtivistas e socioconstrutivistas e que a mídia retoma e reforça esses discursos em sua qualidade de discurso institucional. Porém, conforme Foucault assinala, a vontade de verdade é mais profundamente reconduzida "pelo modo como o saber é aplicado em uma sociedade, como é valorizado, distribuído, repartido e de certo modo atribuído" (FOUCAULT, 1971/2008, p. 17), além de funcionar de forma a retomar os outros dois princípios de exclusão: a interdição (coerções sobre o que pode ou não ser dito) e a separação e rejeição (coerções sobre o status de quem fala).

Quando um dado anúncio diz, por exemplo, "aqui você aprende na prática", não é necessariamente o suporte institucional científico construtivista que serve de apoio; tampouco pode a mídia publicitária inscrever seu próprio discurso no verdadeiro, constituindo-se como uma instância que exerce essa coerção sobre outros discursos. A ideia de interação em "aqui você aprende na prática" pode não dizer respeito nem se apoiar no conceito de inteligência conceitual de Piaget (1970) e o papel da ação na construção do conhecimento, mas certamente é sustentado pelo conjunto de práticas sociais orientadas para a ação que leva ao êxito e não à "verdade". Ou seja, não se trata de uma intervenção que constrói conhecimento, mas de uma ação que leva ao sucesso. Em uma sociedade como a nossa, onde circulam enunciados como "quem sabe faz, quem não sabe ensina", conhecimento e sucesso não necessariamente coincidem. O desejo e o poder, que é justamente o que está em jogo na vontade de verdade (FOUCAULT, 1971/2008, p. 20), não deixam de se orientar pelo sucesso.

A inscrição do discurso da interação em sala de aula como experiência engajadora e eficaz é apoiada por suportes institucionais que almejam e conquistam finalidades práticas: o senso comum daquele ou daquilo que é bem-sucedido. A interação representada como experiência positiva encontra espaço para se inscrever no verdadeiro pela valorização de conexões sensório-motoras que são essencialmente individuais, distanciados, por exemplo, de esquemas representativos e reflexões. Se, conforme Foucault, a própria verdade esconde a vontade de verdade e "assume a tarefa de justificar a interdição e definir a loucura", aquele que fala é desqualificado por seu insucesso e aquilo que se fala é desqualificado por sua (às vezes aparente) desconexão com o fim prático. O "pensar" e o "refletir", mesmo sendo verbos de ação, são distanciados da ideia de "fazer", compreendida no sentido estrito da finalidade prática. Interagir é fazer algo com ou para outra pessoa ou coisa. 
Há uma verdadeira proliferação de livros do tipo "how-to" na área de ensino de inglês. Basta fazer uma busca rápida em livrarias e distribuidoras de livros nessa área para encontrarmos dezenas de títulos que oferecem "receitas" sobre como ministrar a aula, estratégias descritas para imediata aplicação, "ferramentas", e atividades descritas de forma que até mesmo os elementos que podem ou devem ser adaptados são apontados com orientação sobre como isso pode ou deve ser feito. Até mesmo os tradicionais livros de gramática adotaram títulos com essa conotação. $O$ livro "Practical English Usage”, de Michael Swan, é acompanhada da seguinte descrição no site Amazon²5:

This unique reference guide addresses problem points in the language as encountered by learners and their teachers. It gives information and advice that is practical, clear, reliable, and easy to find. Most of the book is about grammar, but it also covers selected points of vocabulary, idioms, style, pronunciation, and spelling.

Entre outros títulos, encontraremos expressões, como "TEFL Lesson Plans For Dummies", "The ESL Teacher's Survival Guide", "Ready-to-Use Strategies", "ESL Classroom Activities for Teens and Adults", e "How to teach englsih". Além disso, uma parcela considerável de trabalhos apresentados em conferências da área de ensino de inglês têm títulos e descrições com essas conotações.

A difundida "abordagem comunicativa" ou o "foco na comunicação" se traduz no verdadeiro como algo correspondente também a um fim prático e se distanciam do desejo pelo conhecimento sobre a língua. O saber sobre a língua é associado a abordagens ultrapassadas, como os métodos baseados em tradução ou a uma experiência morosa que pode não levar ao êxito. Nesse sentido, o foco na comunicação se traduz em foco no uso "real" (prático) da língua, o que remete ao conceito de língua como ferramenta e como código linguístico, ironicamente se distanciando do conceito de língua como prática social.

Evidentemente, esse domínio do verdadeiro não é homogêneo e outras relações (não-hegemônicas) são possíveis, porém as coerções da valorização do sucesso, do (fim) prático e do entretenimento (espetacularização da prática e do sucesso) são fortes o suficiente para serem exercidas sobre outros discursos, inclusive o científico, conforme é evidenciado também adiante, ao refletirmos sobre

${ }^{25}$ Acessado em 01/11/2016: https://www.amazon.com/Practical-English-Usage-MichaelSwan/dp/0194420981/ref=sr 1 1 ?ie=UTF8\&qid=1499533109\&sr=8-

1\&keywords=Practical+English+Usage. 
diferentes conceitos de interação e interatividade. Tal é a arbitrariedade, a violência e a institucionalização do verdadeiro e a operação da vontade de verdade na ordem dos discursos que são produzidos e circulam no contexto de ensino de inglês em escolas de cursos livres, retomando os princípios de interdição e rejeição do discurso, exercendo coerções sobre aquilo que pode e o que deve ser dito "interativo" nesse contexto.

\section{Conclusões}

Ao discutirmos as ideias pedagógicas predominantes em nosso tempo e traçar relações com a constituição do discurso verdadeiro e com a espetacularização da sala de aula, não procuramos estabelecer nenhum tipo de relação causal. Ao contrário, procuramos demonstrar a organicidade dessas relações e a impossibilidade de aprendê-las como fluxos ou eixos, senão como encontros que produzem estados e efeitos. É possível afirmar que, em grande medida, o corpus em análise desta tese é um recorte das marcas de alguns dos efeitos desses encontros. 


\section{Capítulo 3}

\section{O PROBLEMA DA INTERAÇÃO}

O objetivo deste capítulo é refletir sobre o conceito de interação na literatura que trata diretamente desse conceito na área de comunicação e de estudos da mídia, buscando relações com teorias de aprendizagem. No processo abordamos alguns dos efeitos de sentido das representações da interatividade no discurso da mídia publicitária que representa as aulas de inglês em escolas de cursos livres. Ao refletir sobre o conceito a partir de uma pesquisa bibliográfica, discutimos os elementos de tensão e conflito implícitos à interação e que são silenciados nos discursos hegemônicos.

Explorando esses meandros, nesta parte, primeiramente discutimos os pontos de tensão entre a literatura sobre interação e interatividade e as ideias construtivistas. Em seguida, abordamos alguns dos principais entendimentos sobre o conceito de interatividade e, então, criticamos esses entendimentos, explorando um pressuposto em comum e procurando deixar entrever contribuições para caminhos conceituais alternativos para a compreensão da interação, principalmente no processo de ensino e aprendizagem. 


\section{Desfiguração do construtivismo e do socioconstrutivismo}

Poder-se-ia dizer grosseiramente, porém de forma que fosse amplamente aceito como verdade, que os indivíduos aprendem pela interação. Ocorre que essa afirmação, por ser uma simplificação, pode se tornar tão imprecisa quanto enganosa. Para escapar de suas armadilhas, é preciso distinguir desenvolvimento, aprendizagem e interação em Piaget (1970) e Vygotsky (1978).

Desenvolvimento é a evolução, crescimento ou aperfeiçoamento de estruturas mentais; aprendizado é o processo de construção do conhecimento e comportamento; e interação é a ação (intencional ou não) do indivíduo sobre o meio e o que acontece em resposta, bem como a ação ou evento do meio e a resposta do indivíduo. Piaget e Vygotsky divergem na relação entre essas três instâncias. Em Piaget, o desenvolvimento é endógeno, ou seja, as estruturas mentais amadurecem e se desenvolvem como condição para a aprendizagem de forma que seja o estágio de desenvolvimento das estruturas mentais que determina aquilo que é ou não possível de ser aprendido, naquilo que descreveu como uma alternância entre processos de assimilação e acomodação. Em Vygotsky, o desenvolvimento é social, ou seja, as estruturas mentais amadurecem e se desenvolvem impulsionadas pela aprendizagem situada. Assim, é o processo de aprendizagem que estimula o desenvolvimento e amadurecimento das estruturas mentais.

(...) learning awakens a variety of internal developmental processes that are able to operate only when the child is interacting with people in his environment and in cooperation with his peers. (...) [L]learning is not development; however, properly organized learning results in mental development and sets in motion a variety of developmental processes that would be impossible apart from learning. (VYGOTSKY, 1978/1978, p. 90)

Tanto em Piaget quanto em Vygotsky ${ }^{26}$, o desenvolvimento não coincide com o aprendizado, assim como a interação não coincide com a aprendizagem nem com o desenvolvimento. A aprendizagem é um processo que acontece a partir da interação

\footnotetext{
${ }^{26}$ Há outras importantes diferenças entre as duas teorias. Por exemplo, em Vygotsky a aprendizagem acontece por mediação da linguagem e de pares mais desenvolvidos em situações de resolução de problemas; enquanto em Piaget (1970) a aprendizagem acontece em um processo de assimilação de novas informações e acomodação desse novo, envolvendo uma reconfiguração das schemata já existentes no indivíduo. No entanto, essa e outras diferenças não são relevantes aqui.
} 
no sentido de que tem a interação instância mediadora, tanto quanto as ferramentas e a linguagem, e não no sentido de ser pressuposto ou inerente à interação.

Dizer que os indivíduos aprendem pela interação pode ser enganoso quando desenvolvimento é tomado como aprendizagem, ao mesmo tempo em que a aprendizagem é tomada como equivalente ou consequência imediata e irremediável da interação que, por sua vez, é tomada nos termos neoprodutivistas. A interação não pode ser uma co-construção, por exemplo, porque a co-construção é parte do processo de aprender e não de interagir. Ao mesmo tempo, a compreensão da interação não deve ser restrita à esfera do indivíduo. Conforme argumentaremos na parte seguinte, a interação é um jogo de co-presença e atualização de efeitos, e dáse como prática social.

Ao atribuir à interação traços como o de co-construção, aproximamos o conceito de interação ao de aprendizagem. "Aprender a partir de interações" se torna "aprender na interação" no sentido de que o aprendizado passa a ser predominantemente o resultado inerente à ação intencional de fazer algo para obter um dado êxito. Nesse sentido, não seria preciso, por exemplo, "aprender a aprender" ou desenvolver estruturas cognitivas e metacognitivas de estratégias de aprendizado. Bastaria realizar uma ação com um fim específico (e prazeroso) para aprender algo ao ter êxito na tentativa de chegar a tal fim. Ou seja, a violência dessa vã paridade entre os conceitos de interação e aprendizagem tem como efeito a ideia de que a aprendizagem é a indefectível consequência de uma ação bem-sucedida.

Nessa esteira, aprender na interação também elide o caráter cognitivo que constitui o construtivismo, principalmente no processo adaptativo que supõe em algum grau o conhecimento do meio pelo sujeito, no sentido de que esse processo fica em alguma medida reduzido à inteligência sensório-motora ${ }^{27}$, coadunando-se com o ideal neoliberal. Para Saviani (2007/2010), a retórica neoconstrutivista privilegia justamente o êxito de um fim prático (e não à construção), e a experiência puramente vivida (sem reflexão) e essencialmente individual. O autor vai além e afirma que assim é possível

\footnotetext{
${ }^{27}$ Segundo Ramozzi-Chiarottino (1984: 58), na inteligência sensório-motora (que se distingue do que Piaget chamou de inteligência conceitual) "as conexões estabelecidas ligam apenas percepções e movimentos sucessivos sem uma representação de conjunto que domine os estados distintos do tempo, [...] ela encontra satisfação na conquista do fim prático perseguido, [...] [sendo que ela] é puramente vivida [...], trabalha sobre as realidades, os índices perceptivos e os sinais motores, e não sobre os signos, os símbolos e os esquemas representativos [...], [e] é essencialmente individual, por oposição aos enriquecimentos sociais adquiridos graças ao emprego dos signos".
} 
compreender "as afinidades do discurso neoconstrutivista com a disseminação da 'teoria do professor reflexivo', que valoriza os saberes docentes centrados na pragmática da experiência cotidiana (2007/2010, p. 436). Essa reflexão pode acabar reduzida à observação do atingimento ou não do objetivo, sendo que em caso positivo a prática deve ser repetida e, em caso negativo, deve ser substituída por outra mais eficiente. Na lógica neoliberal, tanto a reflexão quanto a interação são em alguma medida reduzidas à esfera da experiência sensorial.

Essas relações justificam que a pedagogia e a didática se preocupem em fazer com que o aluno queira interagir e que ele permaneça engajado nas interações pelo máximo de tempo. Justificam porque a qualidade da interação interessa apenas na medida em que deve ser engajadora e motivacional (ou até mesmo divertida e prazerosa), sem se considerar as características e condições sob as quais a interação proporciona melhores oportunidades para o aprendizado. A interação precisa ser interessante e motivadora o suficiente para manter os indivíduos ocupados enquanto aprendem. As características e condições da interação não constituem questões a serem analisadas quando interagir é compreendido como sinônimo de aprender.

\section{0 "novo" em formulações antigas}

Interatividade é um conceito que quase sempre está associado às novas mídias de comunicação. Conforme a internet e as tecnologias de comunicação se desenvolvem, o conceito de interatividade parece se tornar de grande utilidade para diversas áreas do conhecimento, principalmente àquelas mais próximas da Comunicação e dos Estudos da Linguagem. Esse conceito às vezes é usado com grande abrangência e, outras vezes, com relativa especificidade.

Interatividade, por exemplo, pode se referir genericamente à qualidade da mídia da comunicação, algo como uma medida do potencial da mídia em permitir que seu usuário exerça influência na comunicação e interação. Com um sentido muito parecido, interatividade também pode se referir à qualidade da comunicação e da interação em si. Ou ainda, pode referir-se às pessoas envolvidas em um evento comunicativo. 
Nesses sentidos, interatividade pode ser vista tanto como atividade, quanto como propriedade. No sentido de atividade, é considerada como um fazer de mão dupla ou um fazer comunicativo. No sentido de propriedade, não é exatamente tomada como a atividade em si, mas como aquilo que a qualifica ou que permite que ela aconteça, constituindo-se como um atributo que a (ou certos tipos de) interação $\operatorname{pode}(m)$ ou não ter.

Em conceituações mais abrangentes, interatividade é um termo largamente usado com um apelo que beira o intuitivo, pobremente definido no sentido de que se torna difícil explicar o que seja interativo sem recorrer a um raciocínio circular. Além disso, certas distinções se tornam bastante problemáticas, quase que se limitando a especificidades de gênero de discurso. Por exemplo, a interatividade pode ser genericamente suposta como um atributo natural de comunicações face a face, e também proposta para ser replicada em comunicações mediadas por tecnologias, como no caso das características idealizadas do hipertexto, dos videogames e dos chats de voz.

Por outro lado, há abordagens que entendem a interatividade de forma bastante específica, tratando-a como uma propriedade particular da interação. Como se tudo que fosse interativo envolvesse interação, mas nem toda interação fosse interativa; ou ainda, como se nem toda interação fosse igualmente interativa. É quase como se a interatividade fosse uma extensão (RAFAELI, 1988:111); como se ela pudesse ser quantificada por sua quantidade ou por sua intensidade (SILVA, 1998: 29).

Dessa forma, alternando-se ou combinando-se a sua compreensão como atividade ou como propriedade, o conceito de interatividade é frequentemente definido como uma taxonomia, como um estado absoluto, ou como um continuum.

As definições taxonômicas geralmente tomam o conceito de interatividade em seu sentido mais amplo e criam uma tipologia de acontecimentos/ações (tomando interatividade como atividade) e coisas (sendo que interatividade seria o conjunto de atributos dessas coisas) que são interativos de diferentes maneiras.

As definições de interatividade a estabelecem como um estado absoluto quando determinam as qualificações (constituindo critérios de interatividade) às quais a comunicação, a ação ou a tecnologia precisam atender para serem interativas. 
Finalmente, em suas definições como continuum também são determinados os critérios de interatividade, mas, diferentemente das definições em estado absoluto, esses critérios constituem polos ou dimensões que representam não apenas diferentes tipos, mas também diferentes graus de interatividade.

O jogo entre os eixos da interatividade como atividade e propriedade, e como taxonomia, estado absoluto, ou continuum continua sendo muito frutífero na produção de definições. Porém, justamente pelo fato dessas definições em última análise se remeterem a essas instâncias ou eixos, elas cometem a mesma falha fundamental: pressupõem uma certa relação causal dentro de um sistema fechado formado por elementos interligados linearmente. Apesar de várias dessas definições trazerem expressões, como co-participação, co-criação, mútua influência, e outros que poderiam apontar para a ideia de um sistema aberto, elas acabam construindo conceitos de interatividade que são ainda presos à uma lógica causal e linear semelhante a modelos tradicionais de comunicação.

Algumas pesquisas trabalham com a noção de que a interatividade é qualificada por dimensões. Heeter (1989) concebe seis dimensões, quais sejam, (1) Complexidade da escolha disponível; (2) Empenho ou aplicação do usuário; (3) Responsividade; (4) Monitoramento da informação; (5) Possibilidade/facilidade de adicionar informação; (6) Facilitação da comunicação interpessoal.

(1) Essa dimensão usa "complexidade" em um sentido muito específico ou até mesmo corrompido, já que funciona como sinônimo de número de opções de informação ou de ações. Quanto maior o número de opções selecionáveis, maior seria a interatividade.

This dimension of interactivity, also referred to as "selectivity", concerns the extent to which the users are provided with a choice of available information. (HEETER, 1989, p. 222).

(2) Essa dimensão pressupõe a dicotomia ativo-passivo e estabelece que há mais interatividade quanto maior for o empenho ou a aplicação ("amount of effort') e participação do indivíduo. Por exemplo, assistir TV seria menos interativo que jogar video-game.

(3) Essa dimensão mais claramente localiza ou restringe a interatividade ao objeto, já que um dado objeto seria mais interativo a medida em que mais ou melhor respondesse (ou possibilitassse a resposta) às ações do sujeito. 
(4) Essa dimensão mede a interatividade conforme a possibilidade de um usuário poder mais ou menos precisamente quantificar e diferenciar as atividades que ocorrem entre pessoas (mediadas por uma tecnologia) ou entre pessoas e uma dada tecnologia.

(5) Essa dimensão também mede a interatividade em uma dada tecnologia, desta vez à medida em que seja mais ou menos fácil para um usuário adicionar informação que seja acessível para o maior número de pessoas possível.

(6) Essa dimensão diz respeito à medida em que uma dada tecnologia pode facilitar ou viabilizar a comunicação interpessoal.

As seis "dimensões" de Heeter são na verdade "traços", "características" ou "atributos" que pretendem abarcar o princípio de que, para que haja interação, é preciso que haja ações realizadas em via dupla, engajamento dos agentes e tangibilidade da informação com "mais opções de conteúdo" (HEETER,1989, p. 225). Ao falar das implicações das "novas tecnologias", Heeter discute como as tecnologias midiáticas proporcionam uma experiência mais interativa e propõe uma descrição de interação, mas suas seis dimensões não rompem fundamentalmente com o modelo tradicional que ela própria se propõe a revisitar e que representa desta forma:

Figura 2: modelo "tradicional” de comunicação

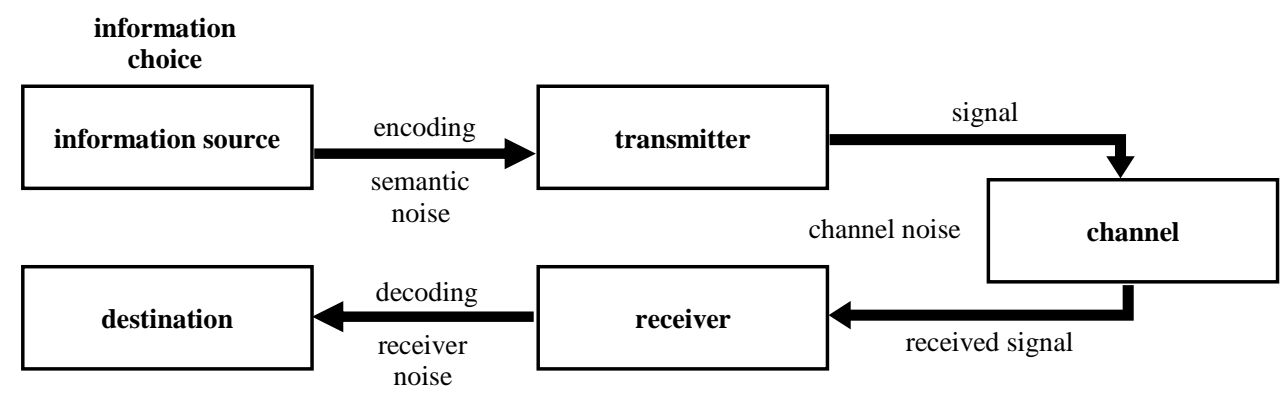

(SHANNON and WEAVER apud. HEETER, 1989, p. 218)

Heeter complexifica os elementos sem questionar o modelo. As dimensões propostas podem ser reduzidas a um fluxo bidirecional de ações, sendo as potencialidades do meio e o engajamento do indivíduo determinantes para o grau de interatividade. A ação em si não constitui uma dimensão nem é qualificada, o que implica sua compreensão como algo neutro (não estando sujeita a gradação ou qualificação) ou intrinsicamente positiva. A ideia de um canal continua presente como 
uma tecnologia que intermedeia as ações dos indivíduos e por onde passam informações. Esse canal possibilita mais ou menos interação conforme oferece mais ou menos escolhas para o usuário (source) ou conforme suas propriedades possibilitem ou facilitem o monitoramento e a adição de informação, e a comunicação pessoal, a qual poderia ser representada em um sistema com setas de duas direções que alternam as posições de source e destination. As terminologias e descrições desenvolvidas e dos "novos" elementos que são postos em jogo no modelo de Heeter são baseados em uma lógica causal linear, na qual as coisas acontecem em cadeia, em sequência e/ou em mão dupla.

As condições de produção da pesquisa de Heeter se situavam em um tempo anterior ao desenvolvimento da internet como plataforma colaborativa (com surgimento de wikis, folksonomia, redes sociais e blogs, por exemplo). Isso significa que os traços da responsividade e da atuação ativa do receptor podem ser considerados avanços com relação ao conceito de interação. No entanto, os modelos que abordam a interatividade a partir desse desenvolvimento da internet também não superaram a lógica causal linear. Esse modelo de Heeter constitui um conjunto de propriedades que podem ser satisfeitos em diferentes graus (continuum) e ser classificado (modelo taxonômico) de acordo com tais diferenças. Outros modelos seguem compreendendo a interação ou interatividade ora como atividade, ora como propriedade, a partir de uma taxonomia, de uma descrição de estado absoluto, ou de um continuum.

McMillan \& Downes (2000) propõem uma definição de interatividade baseada em outras seis dimensões. São elas: (1) direção da comunicação; (2) flexibilidade do sincronismo; (3) senso de lugar; (4) nível de controle; (5) responsividade; e (6) percepção do propósito da comunicação. Esse modelo também se constitui como um conjunto de traços que podem ser mais ou menos satisfeitos e, assim, serem usados para dispor os "objetos" interativos para formar uma taxonomia. Em relação à proposta de Heeter, os autores avançam em dois pontos: flexibilidade do sincronismo e senso de lugar. Os autores criam a dimensão da flexibilidade do sincronismo para se referir a como a sincronicidade deve estar a serviço das necessidades e expectativas de quem se comunica. Já o senso de lugar é a dimensão que se refere ao espaço virtual criado pelo ciberespaço, para o qual os indivíduos são "transportados" ao se comunicarem (MCMILLAN \& DOWNES, 2000, p. 169). Tratam-se de dois avanços 
importantes porque abrem portas para contrastarmos e articularmos a ideia de responsividade com sincronicidade, e para problematizarmos a constituição do referido "espaço virtual".

Com relação à flexibilidade do sincronismo, seriam bastante produtivas questões como: Uma resposta automatizada imediata pode ser percebida como interativa? Quais são os efeitos que ela pode ter? Uma resposta humana assíncrona pode ser percebida como interativa? Uma resposta automatizada pode se passar por humana? Ou ainda, uma resposta humana pode ser percebida como automatizada? Os autores não respondem essas perguntas porque não chegaram a elas. No modelo de Mcmillan e Downes, a tecnologia é o canal da interação ou algo com o que se pode interagir, e não, por exemplo, algo que possa nos abordar e provocar, convidando-nos a responder e reagir. Diante do dado da sincronicidade poder ser percebida como mais ou menos importante na percepção da resposta (responsividade) em diferentes situações, os pesquisadores concluem que a sincronicidade é importante por sua flexibilidade em relação às demandas da situação e às qualidades dos recursos de comunicação, negligenciando em parte a complexidade que pode haver nos contratos de comunicação com relação à urgência de resposta e outras qualidades dos sentidos que podem ou não ser produzidos por um maior ou menor imediatismo da resposta. A sincronicidade não deveria ser um traço para determinação de mais ou menos interação, de maior ou menor interatividade; mas sim um elemento de análise de efeitos de sentido. No entanto, para Mcmillan e Downes o fator chave com relação a sincronicidade é o grau de controle dos indivíduos sobre o tempo de resposta a depender da natureza da interação (MCMILLAN \& DOWNES, 2000, p. 168). Por exemplo, a sincronicidade seria menos importante no caso de uma pergunta enviada por e-mail (nesse caso a seria possível estabelecer uma relação interpessoal sem sincronicidade) e seria mais importante no caso de um debate em um chat.

Essa conclusão a que os pesquisadores chegam já está contida na pergunta da entrevista dos sujeitos de pesquisa a partir da qual os autores desenvolveram o artigo que reporta a pesquisa:

\footnotetext{
How importante do you think it is for interactive communication to occur in 'real-time'? In other words, is it necessary for responses - in order to be deemed 'interactive responses' - to be immediate? (MCMILLAN \& DOWNES, 2000, p. 176)
} 
A pergunta aborda apenas o quanto a responsividade pode requerer algum grau de sincronicidade para ser interativa, negligenciando qualquer outra natureza de relação entre responsividade e sincronicidade e de produção de sentidos.

Quanto ao senso de lugar, os autores não se questionam, por exemplo, onde e como é constituído esse lugar. Presume-se que o lugar existe "lá" (onde quer que seja) e que é para lá que os indivíduos vão. Os autores chegam a ideia de senso de lugar pela declaração de sujeitos de pesquisa que descrevem a percepção de estarem em um lugar virtual com seus pares. Pela lógica linear causal que governa seu modelo, os autores concluem que um determinado espaço eletrônico pode se constituir como tal lugar (se tiver determinadas propriedades) para aonde os indivíduos podem figurativamente se transportar. Essa dimensão de senso de lugar é subdesenvolvida na medida em que o "espaço virtual" que constituiria o lugar para onde são transportados os indivíduos é interpretado como "espaço eletrônico", construído pelo tear de diversos recursos e interações mediadas:

Some of the factors that may help to create a sense of place include greater use of multiple types of media and greater opportunity for interchanges among the participants. (...) [T] he more interactive that a computer mediated communication environment becomes, the more likely that the individual will feel that he/she has been transported to a virtual place. (MCMILLAN \& DOWNES, 2000, p. 14)

O subdesenvolvimento desse elemento fica evidente no raciocínio circular exposto na citação: quanto mais interativo, mais o indivíduo se sentirá transportado; quanto mais o indivíduo se sentir transportado, mais interativo o ambiente pode ser considerado. Afinal, o senso de espaço é uma dimensão da interatividade, ou é resultado dela? Os autores descrevem os fatores da criação do senso do lugar, mas tais fatores são ao mesmo tempo as características de interação descritas nas demais dimensões. Os autores não explicam como ou por que o senso de lugar seria uma dimensão da interatividade e simplesmente afirmam que a interatividade é maior quando o ambiente cria o senso de lugar (MCMILLAN \& DOWNES, 2000, p. 173). É preciso uma compreensão mais profunda sobre o que é exatamente esse espaço virtual $^{28}$ para de fato avançar com relação ao conceito de interação.

\footnotetext{
${ }^{28}$ Em nossa pesquisa de mestrado (CARÁ Jr., 2011), sustentamos que os sujeitos não são transportados e que não estão em um lugar eletrônico, mas que são constituídos em um nãolugar. Defendemos que a interação não desloca os indivíduos de um lugar para o outro para encurtar distâncias, mas produz efeitos de presença dos indivíduos um em relação ao outro em um espaço virtual, crianço a percepção de lugar.
} 
Evidentemente, a responsividade, a sincronicidade e o ambiente ou espaço virtual são aspectos abordados por muitos outros pesquisadores. Desde o início dos anos 90, muitas definições de interação ou de interatividade enfatizaram justamente esses aspectos, porém também permeados por uma lógica causal linear. Para Miles (1992, p. 150), “a comunicação interativa envolve responsividade da mensagem para o interlocutor"29 em uma lógica de simples ação e reação. Steuer (1992, p. 84) afirma que "interatividade é a medida da possibilidade dos usuários modificarem a forma e o conteúdo de um ambiente mediado em tempo real"30, no sentido de que o próprio ambiente deve ser responsivo em tempo real às ações dos indivíduos. Para Haeckel (1998), a troca é a essência da interatividade, sendo que essa "troca" compreendida em seu sentido literal, ou seja, a interatividade consistiria no envio e recebimento de informação ou na ação e reação entre indivíduos. Segundo Ha e James (1998), "interatividade é definida em função do quanto os interlocutores podem responder e contribuir com as necessidades comunicativas uns dos outros" ${ }^{31}$ (HA \& JAMES, 1998, p. 461). Pavlik (1998) afirma que interatividade é basicamente uma comunicação multidirecional.

Em todos esses desenvolvimentos os traços da interatividade remetem a ideia de permuta e fluxo em um sistema fechado com polos que são ao mesmo tempo emissores e receptores, a partir dos quais as ações dos indivíduos têm efeitos governados pela lógica da ação e reação. Eles pressupõem que tal fluxo seja bi ou multidirecional de idas e voltas com participação dos interlocutores em tempo real. São visões que ora tomam interatividade como atividade (fluxo de ações) ora como propriedade (das próprias ações ou, principalmente, de tecnologias da comunicação) e, nos dois casos, estipulam condições que definem a interatividade em estado absoluto quando satisfeitas. Mesmo no caso de Steuer e Ha e James, onde é possível apreender a ideia de gradação, as diferentes medidas são mais usadas para distinguir (separar o que é do que não é interativo) do que para classificar (conferir diferentes graus entre o que é menos ou mais interativo).

\footnotetext{
29 Tradução nossa.

30 Idem.

31 Tradução nossa.
} 


\title{
Figura 3: modelo de interatividade
}

Interactivity in Designed Activities

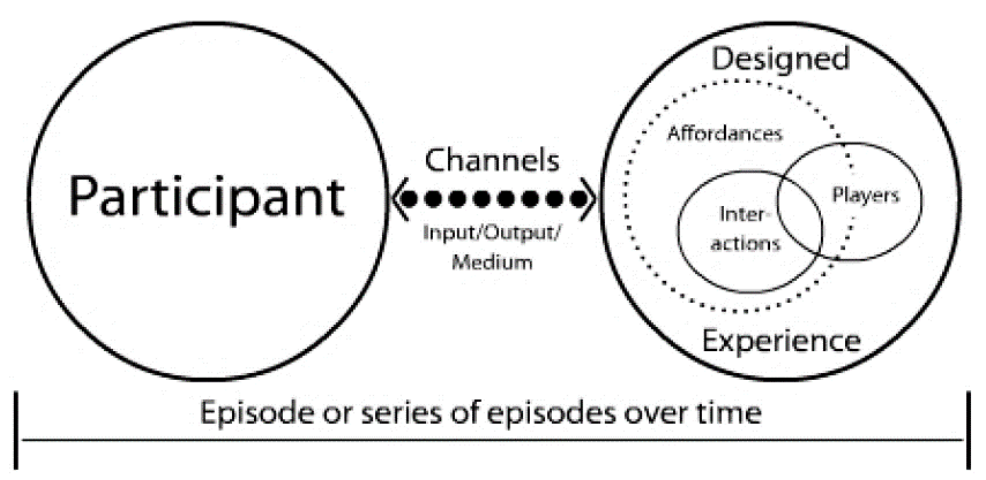

(HEETER, 2000: 9)

Pouco mais de uma década depois, novamente procurando rever ou substituir o modelo tradicional de comunicação, Heeter (2000) propõe um modelo para explicar a interatividade. O modelo proposto por Heeter não avança no sentido de ir além da lógica causal linear na ação e reação, mesmo levando em conta que interatividade está relacionada também com affordances dos objetos e práticas, sendo preciso abordar a experiência conforme ela pode ser percebida, não apenas entre interlocutores, mas também entre eles e o ambiente:

\begin{abstract}
Everything a human does to or with another human can be called an interaction. Human interactions that use media are mediated human interactions. Everything a human does to or with a computer is a humancomputer interaction. [But] I will limit what is considered an interaction on the experience side to experience actions the participant is capable of observing through one or more senses over whatever channels exist to connect the participant to the experience. (HEETER, 2000, p. 9)
\end{abstract}

Por outro lado, o modelo de Heeter apresença um significativo avanço, que é a afirmação de que devemos nos atentar mais para a qualidade da interação do que para a quantidade:

More interactivity is not necessarily good. A poorly designed interface is likely to require more separate interactions and take longer to achieve a sought affordance than a well-designed interface. (HEETER, 2000, p. 10)

No entanto, a lógica de canalização das ações em fluxo impõe limites ao desenvolvimento dessa ideia e nos leva a conclusão de que a experiência bem projetada deve ter certas características. Heeter afirma que a melhor experiência deve requerer o desenvolvimento de certas habilidades, ter fins práticos, dar feedback, deixar o indivíduo se sentir no controle, facilitar a concentração e o envolvimento, e ser mais proeminente que o mundano - "paramount reality". (HEETER, 2000, p. 11). Ao definir características para a experiência melhor projetada, proporcionando a 
interatividade de melhor qualidade, o modelo não deixa de definir a interatividade como um conjunto de características que constituem um continuum da melhor a mais pobre, e que não exclui uma taxonomia da interatividade conforme outras características de mediação de comunicação. A "qualidade" da interatividade é assim abordada como conjunto de características que determinam a maneira de ser boa ou má da interatividade, visando à sua superioridade ou excelência. A qualidade seria intrínseca do ambiente ou do próprio fazer.

A partir do final dos anos 90 e principalmente dos anos 2000, muitas definições passaram a enfatizar justamente essa questão da experiência ou da vivência que o indivíduo co-constrói via tecnologias (interativas) da comunicação. Jensen (1998, p. 201) defende que interatividade pode ser definida como "o potencial de uma dada mídia em permitir que o usuário exerça certa influência no conteúdo e/ou na forma da comunicação mediada"32. Sua definição classifica todos os aspectos da interação em quatro dimensões: transmissão (interatividade transmissora), consulta (interatividade consultiva), conversação (interatividade conversacional) e registro (interatividade registradora). Essas dimensões, como Jensen as chama, foram baseadas em dois aspectos centrais de toda a troca de informações: a questão do proprietário/fornecedor da informação e a do controlador de sua distribuição. Se a informação é produzida e concentrada por um "centro" que controla sua distribuição unidirecionalmente, trata-se de um padrão de interação de distribuição. Quando a informação é produzida e consumida pelos próprios usuários, trata-se de um padrão de conversação. No caso da informação ser produzida centralizada, mas ser consumida por acesso do consumidor (e não por envio unidirecional massificado), trata-se de um padrão de interação consultiva. Quando a informação é produzida descentralizada, mas processada e controlada de forma centralizada, o padrão é de registro. Ou seja, esse modelo de Jensen também se baseia em um fluxo de ida e volta entre duas pontas que alternam ou acumulam posições.

Lombard e Snyder-Dutch (2001) de certa maneira seguem na esteira de Jensen (1999) ao definirem interatividade como "uma característica de um meio no qual o usuário pode influenciar a forma e/ou o conteúdo da apresentação ou experiência mediados". Hoffman e Novak (1996, p. 29) defendem que a velocidade da interação seja uma construção que contribui para a fluidez da informação e das ações,

32 Idem. 
baseada em medidas como o "tempo de espera, o tempo de carregamento" e, em última instância, o grau no qual interagir com a Web pode ser lento e tedioso. Straubhaar e LaRose (1996:12) se utilizam do termo interativo para se "referir a situações nas quais feedback em tempo real é coletado dos destinatários de um canal de comunicação e é usado pela fonte para continuamente modificar a mensagem conforme ela é enviada ao destinatário"33. Interatividade aqui é vista como uma atividade (ou uma experiência) que têm características que a definem e a classificam em maior ou menor grau.

Nessas contribuições, principalmente no caso do trabalho de Hoffman e Novak, talvez seja um pouco mais marcada a noção do interativo como um valor desejável, já que sua ausência fica diretamente associada com o chato e tedioso. Quanto mais adentramos na sociedade do espetáculo ${ }^{34}$ e quanto mais submergimos em valores neoliberais, maior a valorização de traços associados ao entretenimento (diversão, dinamismo, agito, animação, etc.) e ao imediatismo (just in time, responsividade síncrona, interpelação do usuário pelo sistema, proatividade, etc.). A ideia do chato, monótono, lento, tedioso rapidamente se associa a ideia de ausência de interação ou de interatividade.

A importância dada a participação do consumidor no evento interativo ou no manuseio de algo interativo é ainda maior quando se trata de marketing. Day (1998) argumenta, sem grande oposição, que a parte mais valiosa do marketing interativo está em utilizar-se da informação recebida do próprio cliente, em vez da informação sobre o cliente. Em tempos em que os sujeitos e os discursos circulam transmidiaticamente ${ }^{35}$, ter informação sobre o consumidor tem pouca utilidade porque a questão que ainda se imporia é como ter acesso a esse consumidor, conhecendo as especificidades de seu desejo imediato de consumo, conforme impõe a lógica just in time. Ter um canal de mão dupla com o consumidor estabelece mais prontamente uma situação de consumo. Interagir, da perspectiva do marketing, é acessar o mercado; acessar o consumidor; ou, ainda, interagir é consumir. Mais uma vez,

\footnotetext{
33 Tradução nossa.

${ }^{34}$ Entendida conforme Debord (1997/2013).

35 Transmídia diz respeito a fluidez das narrativas ao deslizar pelas múltiplas plataformas de comunicação, sem convergência para um centro. Levando em conta que os meios não são neutros, as diferentes partes ou as "mesmas" narrativas não coincidem consigo mesmas nas diferentes plataformas midiáticas (Kinder, 1991; Ciancia, 2014).
} 
interatividade é tida como atividade ou experiência em uma lógica de fluxo bi ou multidirecional de ações.

Conforme dissemos, o ideal de interatividade tem como referência a comunicação presencial (face a face) e essa lógica que predomina ou permeia muitos dos conceitos (ou muito do conceito) de interatividade é fortemente influenciada por uma visão tradicional da comunicação. Carey (1989, p. 328), por exemplo, defende que as mídias interativas são "tecnologias que fornecem comunicações de pessoa a pessoa mediadas por canais de telecomunicações (ex. uma ligação telefônica) e interações de pessoa-máquina que simulam trocas interpessoais".

Ainda assim, mesmo partindo de pressupostos tradicionais e questionados, alguns pontos importantes foram suscitados já no final dos anos 90. Kiousis (1999) afirma que a interatividade está relacionada à capacidade que os usuários possuem de reconhecer a experiência como uma simulação de comunicação e, com isso, tornarem-se capazes de aumentar sua consciência com relação à "telepresença". Outra pesquisa (NEWHAGEN, CORDES, \& LEVY, 1996, p.165) conceitua a interatividade baseada no "senso psicológico que os remetentes de mensagens têm de sua própria interatividade e da de seus destinatários"36. Na interação é sempre pressuposta uma escolha do indivíduo e, sendo assim, a interatividade não é uma característica do meio, que é apenas como intermediário ou, no máximo, facilitador da interação, mas sim uma característica do indivíduo. Nesses trabalhos, com maior ou menor ênfase, a interatividade é psicologizada ou situada no âmbito da experiência do indivíduo. O indivíduo se percebe em um dado lugar, fazendo escolhas, agindo e vivenciando a interatividade via tecnologias. Aqui a interatividade é atributo das coisas e dos sujeitos, qualificando-os conforme satisfazem características que descrevem uma essência e conforme o nível de engajamento que efetiva um certo potencial interativo. Kiousis (1999) afirma que a interatividade deve ser considerada tanto como qualidade midiática quanto como variável psicológica e chega a uma definição da combinação de vários aspectos. Sua definição amarra a estrutura de tecnologia, o contexto da comunicação e percepção do usuário proporcionando medidas operacionais a cada um. Sua abordagem se concentra ainda mais na percepção e experiência do indivíduo.

\footnotetext{
36 Tradução nossa.
} 
Nessas definições, destacam-se as características que permitem o controle pelo usuário e que preveem recursos que facilitem a comunicação bidirecional e o controle, em uma lógica na qual o síncrono-assíncrono e o estático-dinâmico constituem continua de opostos; mas, principalmente, o envolvimento do usuário, a simulação de comunicação interpessoal, a percepção de comunicação de duas vias, a percepção de interação consigo e com os outros, a escolha do consumidor para interagir, a percepção de navegação e a capacidade de resposta são características em comum das definições.

A heterogeneidade das definições que apresentamos até aqui é apenas aparente. As diferenças não são resultado de teorias alternativas ou de diferentes pressupostos. As diferenças são predominantemente resultado de alternância de foco. As definições se alternam focalizando:

- Atributos ou características do objeto, dos medium, das tecnologias

- Atributos ou qualidades das ações empenhadas pelos indivíduos sobre outros ou sobre objetos, medium e tecnologias

- A atividade ou ação dos indivíduos sobre outros ou sobre objetos, medium e tecnologias

- A atividade ou ação dos objetos sobre os indivíduos

- A experiência e percepção do sujeito sobre as qualidades de suas ações, sobre o que acontece e sobre as qualidades das ações sobre si.

O foco nos atributos do objeto tende a levar a definições taxonômicas, já que os objetos são considerados como canais, meios ou recursos prontos e que contém características. O enfoque em atributos das ações tende a produzir definições de interatividade como um estado absoluto, porque as ações são dadas, selecionáveis e descritíveis por características presentes ou ausentes. A focalização das atividades em si mesmas e da experiência e percepção do indivíduo frequentemente leva a conceitos de interatividade como um continuum ou com uma taxonomia que também vai do menos ou mais interativo.

Diante da aparente falta de consenso sobre o conceito, alguns propõem uma distinção entre interação e interatividade. Wagner (1994) propõe essa distinção de acordo com o meio de comunicação. Para o autor, "a interação ocorre quando objetos e eventos influenciam uns aos outros mutuamente"37 (Wagner, 1994: 20), ao passo

${ }^{37}$ Idem. 
que a interatividade está ligada ao estabelecimento de conexões síncronas de ponto a ponto por meio de tecnologias da comunicação.

Por sua vez, Silva (2000) entende que interação é um termo amplo demais para ser definido de forma a acolher apropriadamente as especificidades ou singularidades do que o autor define como interatividade, compreendida como algo que é imbuído "de complexidade, multiplicidade, não-linearidade, bidirecionalidade, potencialidade, permutabilidade (combinatória), imprevisibilidade, etc., permitindo ao usuário-interlocutor-fruidor a liberdade de participação, de intervenção, de criação" (Idem: 100). Apesar da lista de substantivos que nomeiam as qualidades da interatividade que o autor defende, ao apresentar um exemplo que evidenciasse tais qualidades, tal exemplo acaba apresentando a complexidade menos complexa; a multiplicidade menos múltipla; a não-linearidade mais linear; a bidirecionalidade mais unidirecional; a potencialidade menos potente; a permutabilidade mais limitada; a imprevisibilidade mais previsível; e, mais fundamentalmente, a participação e intervenção menos criativos. Seu exemplo de algo interativo é muito menos interativo do que o autor defende.

um anúncio diz "o músico Philip Glass está gravando um CD interativo." Por que incluir o adjetivo "interativo" ao CD? É certamente por estar este imbuído de disposições para maiores interações ${ }^{38}$. "Ele vai permitir ao usuário escolher para onde a música vai caminhar, acompanhada por imagens". (SILVA, 2000, p. 100)

O "CD interativo" é um álbum com uma peça que tem eventos paralelos que se movimentam dentro de uma linha de tempo, sendo que a pessoa ouvindo pode alternar-se entre esses eventos paralelos.

Tori (2010) também diferencia interação de interatividade, mas não precisamente para estabelecer propriedades distintas a um dos termos. A interatividade é tomada como "capacidade de um sistema de comunicação ou equipamento de possibilitar interação" (TORI, 2010, p. 84), sendo esta compreendida de forma genérica como atividade compartilhada, influência recíproca ou trabalho em conjunto (Idem). Nesse sentido, poder-se-ia falar que existe interação entre pessoas e interatividade entre pessoas e coisas, ou ainda, que existe interatividade promovida por coisas que medeiam a interação entre pessoas.

38 Grifo nosso. 
Também seria possível dizer que interatividade é uma qualidade da interação entre pessoas e entre pessoas e coisas; qualidade composta por características ou dimensões que dependem de fatores midiáticos (meio de materialização da linguagem, seja verbal ou não), inclusive com relação à estrutura tecnológica do meio usado (velocidade, alcance, sincronismo e complexidade sensorial) e de fatores semióticos (processos de produção e negociação de sentido).

Nossa discussão da literatura sobre interação e interatividade mostra evidências de que estamos diante de paráfrases ainda fundamentalmente ligadas ao modelo de comunicação tradicional e sua lógica causal linear. Tal lógica torna-se ainda mais evidente ao nos concentrarmos nos pontos de consenso:

- Comunicação de duas vias, com intercâmbio entre os papeis de emissor e destinatário

- Qualificação da interação como "ativa" ou "passiva"

- Articulação entre sincronicidade e responsividade

- Senso de lugar

- Controle sobre o ambiente e as ações e seus resultados.

- Possibilidade de manipulação do conteúdo, da forma e da dinâmica de um dado ambiente.

A representação abaixo resume os principais pontos de consenso:

Figura 4: modelo de interatividade

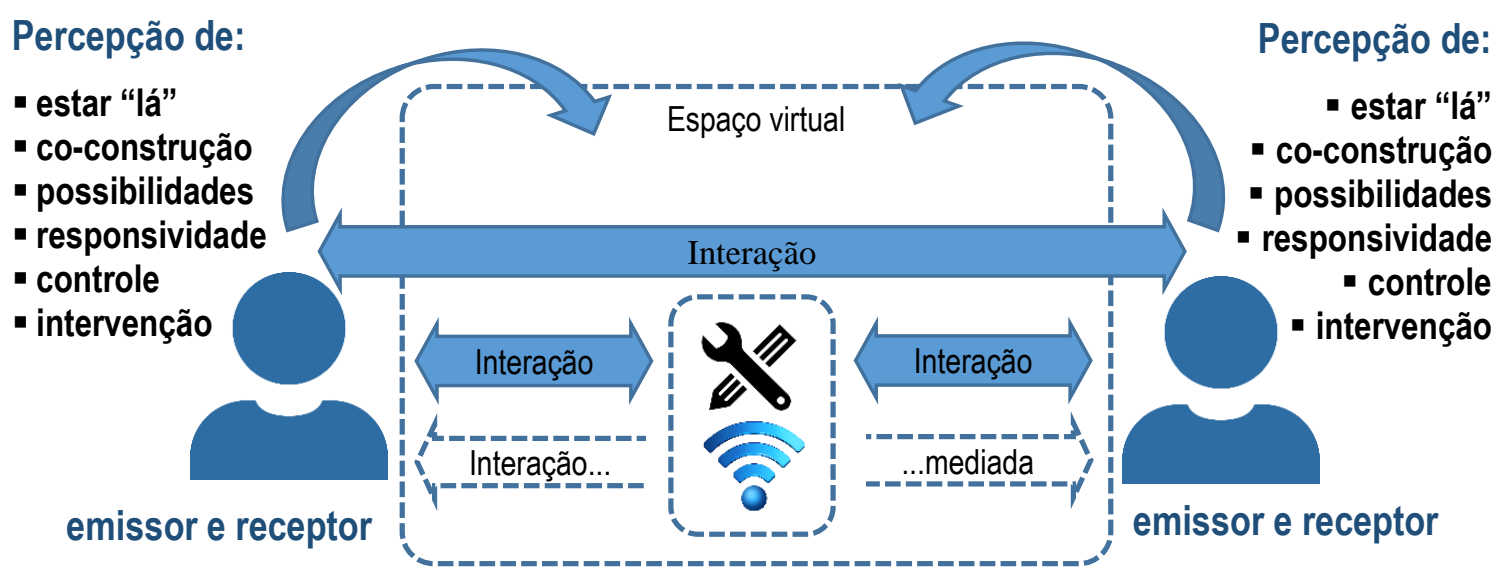

Embora essa representação possa parecer radicalmente diferente e mais complexa do que as últimas por acomodar mais elementos, ela não é senão uma elaboração que incorpora termos carregados de valores mercadológicos e que melhor embalam a interatividade para ser vendida. Ela é flexível, engajadora, dinâmica; ela 
empodera o indivíduo; proporciona escolhas; dispõe possibilidades; envolve o indivíduo em uma experiência ou vivência; ela simula verossimilmente e entretém. A interatividade é muito do que o indivíduo pode desejar em uma sociedade neoliberal. Ainda assim, suas definições não conseguem superar um modelo formado por ações canalizadas que circulam em um sistema fechado de lógica causal linear, afetando e sendo afetadas pelos elementos desse sistema.

Conforme dissemos anteriormente, é amplamente difundida a ideia de que as novas tecnologias da comunicação são interativas e que esse traço, por si só, faz da sala de aula presencial ou eletrônica um lugar melhor. A desgastada ideia de interação é tratada como algo fundamental para o processo educativo e constituem-se discursos segundo os quais a sala de aula, a escola e qualquer ambiente educacional é tanto melhor quanto mais se tiver interatividade. Evidentemente, essas são idealizações, apresentando a interatividade embebida em qualidades positivas.

$\mathrm{Na}$ verdade, sequer dizemos que há interatividade com alguém ou entre pessoas. Com esse sentido, a ideia de interatividade é usada muito mais frequentemente em sua forma adjetiva: interativo(a). Essa idealização pode criar aparentes paradoxos, como a que se materializa na questão que muitos se fazem: afinal, as novas tecnologias nos deixam mais próximos pelas facilidades de conexão ou, pelo mesmo motivo, nos deixam mais distantes? Dizemos "aparente" paradoxo porque, evidentemente, não se trata de estar mais ou menos próximo, mais ou menos conectado; mas sim de novas formas de se estar conectado e de uma reorganização das esferas pública e privada do nosso modo de vida. Trata-se, ainda, de novos modos de se estar/fazer presente, e este é o ponto sobre o qual nos debruçaremos adiante.

Esse discurso que idealiza a interatividade se articula com outros que colocam a razão como lugar do marasmo, da chatice, do desinteresse; e a emoção como algo a ser tocado, aproveitado, alcançado e sentido para que possamos ser envolvidos, entretidos e motivados. Motivação é, de fato, uma das palavras de(a) ordem. A interatividade não está associada a situações como uma conversa "séria" mas a coisas que "ganham a atenção" e mobilizam o indivíduo para (querer) fazer algo; para se engajar em uma ação.

Esse tipo de discurso, supomos, deixa à sobra as descontinuidades e conflitos constitutivos do que é condição para que haja interação; apaga a violência que o 
próprio discurso comete ao promover conexões que criam efeito de isolamento e segmentação. Conforme discutimos, os conceitos de interação e interatividade que debatemos:

a) não conseguem romper com modelos comunicacionais que já deveriam ter sido superados, e

b) negligenciam aquilo que deveria ser constituinte do conceito e não apenas algo dado: a presença.

Por que o conceito de interatividade ainda não conseguiu romper com paradigmas comunicacionais superados? Os primeiros teóricos da informação consideravam que a comunicação era basicamente um processo de transmissão de mensagens. Nesse processo, segundo essa perspectiva, é imprescindível que haja "uma fonte e emissor como pontos de partida da mensagem, um código responsável pela organização e consequente potencial compreensivo e compartilhável da mensagem, um canal por onde a fonte possa transitar, e um receptor que a mensagem visa a atingir e a influenciar" (Santaella, 2004, p. 158).

Quando esse modelo foi criticado, a resposta a ele não rompeu paradigmaticamente com o que é de mais fundamental nele: transmissão de mensagens. As críticas focalizavam o fato de a transmissão de mensagens acontecer "como em um fluxo linear, de mão única” (Santaella, 2004, p. 158). A partir das críticas, outros modelos e conceitos surgiram (modelo pragmático, conceito de negociação, modelo funcional, etc.) e foram responsáveis por avanços no sentido de "evitar a superioridade do emissor e valorizar a dinamicidade do processo" (Santaella, 2004, p. 158), mas nenhum deles parece romper com a ideia de troca de mensagens. Admitese que as mensagens não são fechadas; que os interlocutores exercem influência um sobre o outro na produção das mensagens; que o significado não é interpretado apenas a partir da mensagem verbal; admite-se, enfim, que essa troca de mensagens (e a mensagem em si) é complexa. Mas parece não haver modelo de comunicação em que não há "mensagem transmitida". É como se o primeiro modelo de comunicação tivesse sido "adaptado" para poder continuar "o mesmo".

Esse é justamente o ponto em que as conceituações sobre a interatividade parecem também continuar submetido: a mesma lógica de transmissão é aplicada a interatividade. Ou seja, grosso modo, trata-se da interatividade como transmissão de ações por canais materiais. 
O próprio percurso de desenvolvimento do conceito é semelhante. Em um primeiro momento, podemos conceber um processo de transmissão de ações. Nele, haveria uma fonte e um emissor como pontos de partida da ação, uma materialidade responsável pela sua objetivação e consequente potencial sensitivo da ação, um meio onde a ação acontece, e um ponto de recepção o qual a ação visa a atingir e o qual deve reagir a ela. Nesse primeiro momento, falaríamos de interação.

Esse modelo foi criticado por argumentos similares às críticas ao modelo tradicional de comunicação: a ação era estanque, fechada, previsível e acontecia em um único sentido, sem levar em conta toda a complexidade do evento interativo. A partir dessas críticas, surgem modelos que passam a diferenciar interação e interatividade. São modelos que propõem avanços de tipos muito parecidos com aqueles que descrevemos sobre o modelo de comunicação: participação e intervenção dos envolvidos; bidirecionalidade das ações; e influência multidirecional entre os participantes.

Nesta tese apresentamos uma alternativa para o conceito de interação, articulando o conceito de zona de desenvolvimento proximal (ZPD), conforme Vygostsky (1978), o conceito de efeito de presença, conforme trabalhos anteriores de nossa autoria (CARÁ JR., 2014), e o conceito de rizoma deleuziano (DELEUZE, 1992/2010).

\section{Proposições para compreender a interatividade}

Apesar de não haver senso comum entre os teóricos da interação e da interatividade, eles compartilham dois pressupostos. Um deles, conforme já discutimos, é a ideia de transmissão ou fluxo de ações em um sistema fechado. Com relação ao segundo pressuposto, todos os trabalhos que mencionamos anteriormente entendem que há algo na interatividade que é dado, que existe antes de ela acontecer. Esse algo é a presença. Segundo os diferentes conceitos de interatividade que descrevemos, a presença de quem interage pode ou não ser explicitada, mas é de qualquer forma pressuposta como algo anterior a interação. Não está exatamente aí o problema, senão no fato da presença ser tomada como substância e não como acontecimento. 
Com isso não remetemos exatamente às teorias da semiótica que compreendem a presença como efeito de um "objeto de saber para um sujeito cognitivo" (Fontanille \& Zilberberg, 2001, p. 124). Dessa perspectiva trazemos a ideia de que um dado objeto ou sujeito se faz presente quando a partir de sua materialidade um sujeito interpreta efeitos de sentido que o situa no tempo e no espaço em relação ao "estar lá" desse objeto ou sujeito. Também não remetemos exatamente à semiótica das experiências sensíveis que trata a presença como uma dimensão sensível do sentido ou um sentido que se dá por "contágio" (Landowski, 2002) em uma espécie de encontro direto e imediato entre instâncias enunciativas em ato, ou seja, aqui e agora. Dessa perspectiva, trazemos a ideia de que presença é algo como uma copresença entre coisas ou sujeitos.

Articulando e indo além dessas perspectivas por um viés deleuziano (DELEUZE, 1996), concebemos a presença como um campo problemático produzido por forças virtualizantes, de forma que ela não necessariamente tenha qualidades materiais (seja como soma ou como physis) ou, em outras palavras, que não tem corpo de superfície tangível (Cará Jr., 2011). Estar presente e estar ausente não são disposições que se excluem mutuamente e, em última instância, sequer são disposições. São nós de relações entre materialidades e acontecimentos produzindo efeitos que constituem a latência de presenças que interagem para se atualizar e produzir seus efeitos.

Ao falarmos em presença, não devemos encará-la como "uma coisa", uma substância, nem mesmo como uma qualidade de uma substância. A presença é algo que está, não é dada e não pode ser apreendida senão por seus efeitos. Daí falarmos em efeitos de presença (CARÁ JR., 2014). Os efeitos de presença não estão contidos nos corpos, nos sujeitos, nas situações ou em qualquer outra coisa, nem acontecem em algum sentido e direção. Eles são produzidos na relação mesma entre sujeitos e objetos que se dispõem rizomaticamente.

É possível que uma dada entidade seja percebida mais ou menos presente tanto por aspectos quantitativos quanto qualitativos da presença. A percepção do aspecto qualitativo impõe uma dimensão subjetiva à quantidade, ou seja, os efeitos de presença são percebidos mais ou menos intensamente também em função do(s) tipo(s) de efeitos. 
Levando em conta que os efeitos de presença são acontecimentos, quantificar a presença consistiria em contabilizar tais efeitos em um dado tempo e espaço, de maneira que um sujeito poderia ser considerado como mais presente a medida em que ele acontece mais vezes em um dado tempo e espaço. Em uma sala de aula, quando o professor explica um conceito ou propõe uma atividade enquanto estão trocando mensagens nos seus celulares, eles não estão presentes na aula; estão presentes no espaço mesmo que é criado pela interação e onde os efeitos de presença acontecem. É o ato mesmo de falar, por exemplo, que produz os efeitos de presença do sujeito em um dado lugar e situado no tempo. Uma conversa não é simplesmente um potencial ou uma possibilidade dada pela presença presumida dos sujeitos, já que a própria interação produz efeitos de presença. Toda interação produz, com maior ou menor intensidade, um espaço virtual que delimita e é delimitado pelos efeitos de presença, mas é a interação envolvendo os meios eletrônicos que desfazem o efeito de coincidência entre a materialidade de um indivíduo e a presença de um sujeito.

Essa reflexão nos leva à questão dos aspectos qualitativos da presença e sua latência conflituosa e produtiva. Em trabalhos anteriores, defendemos que a indicação da intensidade dos efeitos de presença é complexa e envolve três referenciais: tangibilidade (por suas características materiais), responsividade (por suas características relacionais), e sincronicidade (por sua relação com o agora em um dado espaço virtual). Os três referenciais não são essências; são fatores contingentes de uma relação do um com sua alteridade. A percepção de si (sua materialidade e suas relações em um aqui e agora) é a percepção do outro.

Esses três referenciais assumem papéis de eixos e podem tomar a forma de gráfico em até três dimensões. Compreendemos que os efeitos de presença mais intensos são tridimensionais, nos termos dos três eixos mencionados ${ }^{39}$.

\footnotetext{
39 Poderíamos expressar esses efeitos de presença pela equação $z^{2}=x^{2}+y^{2}$, sendo que a intensidade da presença seria proporcional ao tamanho da esfera. Mas, como dissemos, a pura e simples quantificação da presença seria um reducionismo, já que estaríamos negligenciando ou descartando o caráter qualitativo dos efeitos de presença.
} 
Figura 5: modelo das dimensões de efeitos de presença
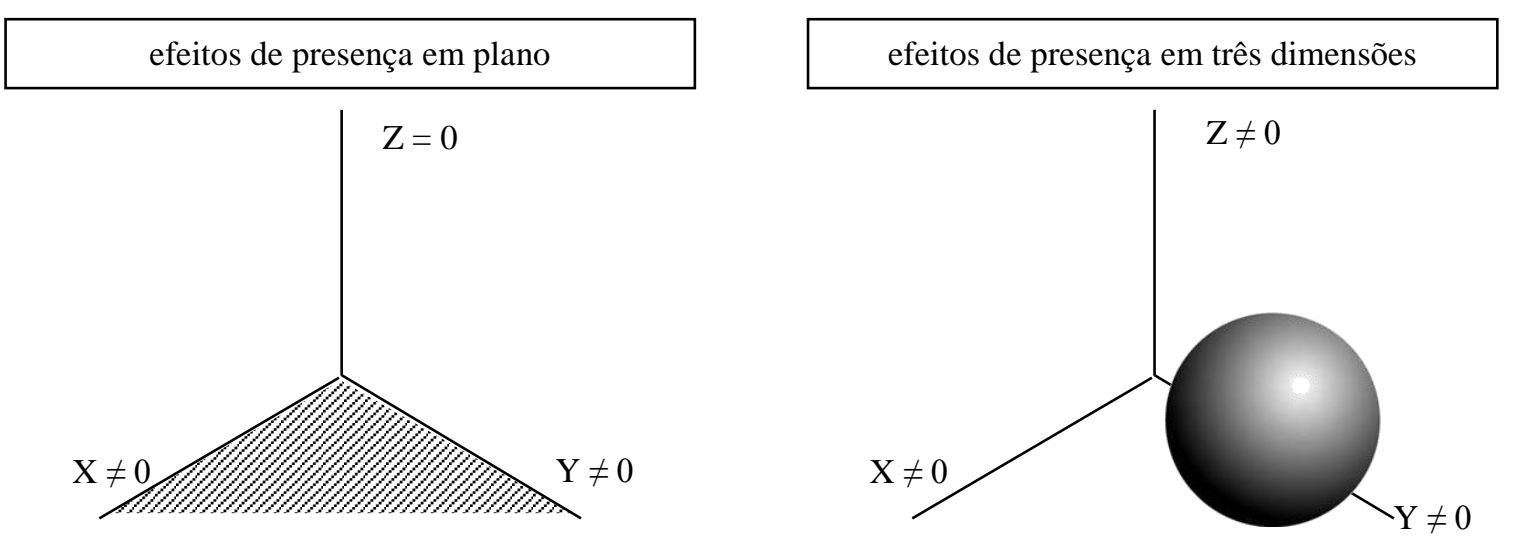

(Cará Jr., 2014, p. 39)

Os efeitos em três dimensões nos capturam e nos desterritorializam. Esses efeitos não nos transportam; eles nos constituem em um lugar percebido como aqui, mas que é lá: é uma teia rizomática de relações e efeitos dos acontecimentos. Não surpreendentemente e sem qualquer estranhamento, nós nos vemos presentes em um não-lugar que é lá e aqui (Cará Jr., 2011), sempre em relação a outra presença. Essa instância do conceito de efeito de presença oferece uma alternativa que nos tira da argumentação circular de Mcmillan \& Downes (Mcmillan \& Downes, 2000:169) com relação ao senso de lugar e o espaço virtual, mas que é continua sendo insuficiente para abordar a latência produtiva da interação. Para tanto, é preciso que nos aprofundemos no argumento de que os efeitos de presença são acontecimentos.

Ora, se a presença como efeito não é anterior; se ela não precede a interação; se a presença, enfim, não pode ser tomada como condição da interatividade, a interação é a relação intrínseca entre virtualidades que constituem suas presenças relativas uma à outra em um processo de atualização. A interação não coincide com a ação em si. Ela é a potência constituída na relação entre ações (eventos, acontecimentos) que pode se atualizar, ou seja, produzir um evento ou acontecimento que é por implicação singular e constituído em um aqui e agora, e que estará em relação com outros eventos ou acontecimentos. Os acontecimentos produzem e são eles próprios efeitos, dotados de materialidades em disposições rizomáticas no tempo e no espaço.

Para que duas presenças interajam, elas devem estar; e ao mesmo tempo é justamente ao interagirem que são produzidos efeitos de presença. A presença é uma virtualidade e a interação é, ao mesmo tempo, constituinte dessa virtualidade e o 
processo de suas atualizações. A presença do um só é em relação à sua alteridade em um processo de mútua constituição (primeira instância de interação), e seus efeitos de presença (sua atualizações) são produzidos pelas relações entre suas ações (segunda instância de interação). Se a presença virtual é relacional e não uma essência e, portanto, sua unidade não é senão uma interpretação de seus efeitos, então toda ação não pode ser essencialmente individual. Por uma lógica similar a que nos leva a afirmar que o sujeito não é origem do seu dizer e é falado em seu discurso que é historicamente constituído, as ações em relação (interação) são sócio-culturais.

Essa articulação teórica, além de se coadunar com nossos conceitos de discurso e sujeito, também oferecem respostas para perguntas relacionadas ao papel da interação na aprendizagem, como as que Reusser (2001, p. 2058) se propõe a responder:

\begin{abstract}
How can individuals who personally construct their knowledge independently of each other come to the same or similar cognitive structures? How can we share a knowledge of our culture if people are conceived of as being solo learners, and socially isolated Robinson Crusoe figures? One striking answer, which at the same time challenges traditional (Western) epistemological constructivism, stems from symbolic interactionist (Mead, 1934) and sociocultural theory (Vygotsky, 1962). It claims that learning is fundamentally a social activity.
\end{abstract}

Se a interação é, em segunda instância, o conjunto de relações entre ações e entre os efeitos e latências das ações (que sempre remetem a um plano problemático), e se quisermos nos ocupar da questão da latência produtiva da interação para a aprendizagem, devemos abordar a questão da qualidade da interação em termos de acontecimentos em encontro a operações e estruturas cognitivas e afetivas, e à aprendizagem compreendida como processo fundamentalmente social.

Para tanto, devemos primeiramente revisitar a zona de desenvolvimento proximal, conforme Vygotsky (1978, p. 83-84):

\footnotetext{
an essential feature of learning is that it creates the zone of proximal development; that is, learning awakens a variety of internal developmental processes that are able to operate only when the child is interacting with people in his environment and in cooperation with his peers. (...) properly organized learning results in mental development and sets in motion a variety of developmental processes that would be impossible apart from learning. Thus, learning is a necessary and universal aspect of the process of developing culturally organized, specifically human, psychological functions. To summarize, the most essential feature of our hypothesis is the notion that developmental processes do not coincide with learning processes. Rather, the developmental process lags behind the learning process; this sequence then results in zones of proximal development.
} 
Ao contrário de significativa parcela das representações imagéticas do conceito de ZPD, não podemos compreender a zona de desenvolvimento atual como uma esfera e a desenvolvimento proximal como uma faixa que marca a porção em expansão da esfera. Essa representação pressupõe uma unidade autônoma da individualidade em relação ao meio. Diferente da obra de Bakhtin, seu contemporâneo, as valiosas contribuições de Vygotsky em "Mind in Society" (1978) sugerem que o plano social e o plano psicológico são separados, e que a atuação do indivíduo sobre o meio (que o antecede em termos ontogênicos) é mediada. Na obra de Bahktin, especialmente em "Marxism and the philosophy of Language" (1929/1973), não há separação entre os planos psicológico e social porque eles são considerados mutuamente constitutivos. O signo linguístico, que para Vygotsky é um elemento mediador da relação entre sujeito e mundo, para Bakhtin é constituinte do sujeito e do mundo. Os conceitos de dialogismo e alteridade em Bakhtin sustentam que não há separação entre esses planos. Além disso, tal representação da ZPD abre espaço para a concepção do conhecimento como homogêneo e de sua construção como um processo cumulativo, e para a ideia de que o amadurecimento de estruturas cognitivas seja uma progressão de expansão unidirecional, sempre para "fora".

O conhecimento é melhor representado como um rizoma, sendo que as áreas mais densas podem dar a impressão de formar um círculo e as áreas mais esparsas podem parecer ser sempre marginais às áreas mais densas, mas há importantes distinções:

Figura 6: modelo de zonas de desenvolvimento

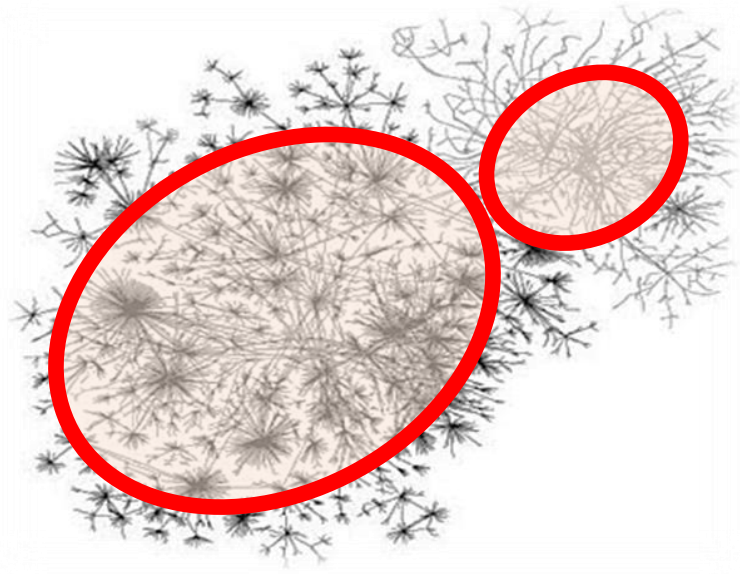


- Não há áreas prontas. Mesmo o que é tido como zona de desenvolvimento atual continua sujeita a transformações e amadurecimento.

- Não há uma zona de desenvolvimento atual e uma de desenvolvimento proximal, mas sim diversas delas.

- As zonas tidas como de desenvolvimento proximal não são fundamentalmente diferentes daquelas tidas como de desenvolvimento atual. Elas apenas são menos maduras e têm menos pontos de articulação.

O indivíduo, ao agir sobre o meio, constitui uma subjetividade e atualiza sua presença em uma rede de relações entre ações (interações), sendo que os efeitos de presença são percebidos justamente nos encontros com as ações e suas materialidades. Esses encontros constituem pontos de tensão, uma latência, um plano problemático a partir do qual a presença produz seus efeitos e o aprendizagem pode acontecer. As operações cognitivas e afetivas que uma determinada tarefa ou situação-problema demandam e as ações dos envolvidos se encontram e constituem potencial de aprendizagem, despertando processos de amadurecimento de estruturas.

Ao atualizar sua presença nessas relações, o sujeito interpreta affordances dos objetos e os sentidos nas ações e práticas sociais em que se encontra implicado. As ações e efeitos, postos em relação, podem acordar uma maior quantidade e variedade de processos em operações cognitivas e afetivas numerosas e variadas em diferentes modalidades de sentido (modes of meaning).

Se a interação não tem qualidades positivas ou negativas porque é uma latência formada por encontros, tensões e relações, as atividades e práticas nas quais os sujeitos atualizam sua presença devem promover pontos de contato para esses encontros, tensões e relações também como uma rede ou rizoma. Ou seja, podemos avaliar uma atividade que se propõe a promover interação como uma unidade em si e como um complexo.

Podemos avaliar a ação ou evento da atividade por sua repercussão ou ressonância, que diz respeito ao papel das ações individuais e coletivas dos envolvidos nas práticas e eventos para um "todo provisório", um resultado ou uma etapa. É o movimento contrário da alienação, ou seja, trata-se de abordar a 
possibilidade do sujeito se reconhecer nos efeitos e nos produtos daquilo que faz, no sentido de que reconhece o eco de suas ações em seus efeitos, em eventos decorrentes, ou em seus produtos; diz respeito à percepção que temos do grau de importância que a nossa intervenção tem para o "resultado" ou a sequência das coisas, contribuindo para a interpretação do propósito da atuação sobre o meio.

Também podemos avaliar a ação ou evento da atividade por seu caráter socioafetivo, ou seja, pela maneira como os sujeitos se relacionam entre si e com os objetos, e pela intensidade com que se implicam na atividade, capturados e mobilizados por identificações. Nenhuma atividade guarda em si a qualidade de ser motivadora, interessante ou prazerosa, não sendo possível saber antecipadamente como e se haverá identificações. Por outro lado, é possível avaliar traços e objetos que podem ser agentes de identificações, incluindo a variedade de materialidades de substâncias e de acontecimentos a partir das quais construímos sentido (já que o significante é elemento fundamental na identificação), as formas de estar no mundo e na situação imediata, o lugar e as posições-sujeito, e de traços do outro que tal atividade pode fazer emergir. Não se trata, portanto, de procurar na atividade elementos intrinsicamente divertidos, prazerosos ou motivadores.

Finalmente, podemos avaliar uma atividade pela forma como ela interpela 0 sujeito, implicando-o em operações cognitivas e metacognitivas, como em situaçõesproblema, que colocam em relação objetos (instrumentos e coisas), sujeitos e acontecimentos (ações e eventos, como o discurso). Nós, por exemplo, avaliamos, comparamos, verificamos, ilustramos, relacionamos, analisamos, criticamos e definimos as coisas e os eventos, manipulando objetos e acontecimentos, na linguagem e em diferentes modalidades de sentido.

No entanto, essas descrições são simplificações: abordar a atividade como uma unidade é uma descomplexificação. A atividade é melhor compreendida como um complexo, como uma rede formada pelos elementos que descrevemos e não por unidades de ações que contém essas características e que podem ser encadeadas. Não é possível avaliar as atividades nas quais o sujeito está implicado simplesmente listando e quantificando as ações: escrever, ouvir, discutir, completar, formar, marcar, etc. As operações cognitivas não podem ser abstraídas da situação imediata, da constituição do sujeito, e dos objetos. Se quisermos avaliar a qualidade da interação, devemos procurar compreender as relações entre as ações, sujeitos e linguagem, 
sendo que "qualidade" não deve dizer respeito "ao quanto é melhor ou pior", mas aos elementos qualitativos que produzem diferentes efeitos e que são mais um menos produtivos em determinadas relações entre as ações, sujeitos e linguagem em um dado contexto.

\section{Qualidades da interação em planos de aula}

Quais são as possibilidades práticas de lidar com todas as questões teóricas que discutimos sobre a interação? Talvez seja preciso um referencial teórico-prático para a elaboração e prática de aulas interativas, dentro do que consideramos que seja mais produtivo para a aprendizagem de uma língua e coadunado com objetivos educacionais, mas tal referencial não pode ter a pretensão de esgotar, limitar ou definir os traços da interação. Conforme vimos, atribuir traços ou características que descrevam o que pode ser mais ou menos interativo nos coloca em uma posição de perspectiva essencialista e sujeita a idealizações mercadológicas mais do que didático-educationais. O objetivo desse referencial teórico-prático deve ser a de levar em conta que a interação tem uma instância de constituição dos sujeitos e a reverberação de seus efeitos de presença, uma socioafetiva, e uma (meta)cognitiva. Nós vivenciamos o mundo irremediavelmente imersos em relações, na linguagem, sócio-historicamente situados, construindo sentidos (making meanings) com todos os nossos mecanismos de percepção (senses); e essas relações são ao mesmo tempo harmônicas, conflituosas e descontínuas.

Esse referencial teórico-prático também não pode servir de receita para elaboração e condução de aulas. A aprendizagem é um processo complexo e não nos permite manter a ilusão de que ela possa ser planejada ou prevista dessa forma. $O$ propósito do referencial teórico-prático deve ser o de funcionar como conjunto de princípios para elaboração de aulas interativas no sentido de se constituir como ponto de partida para reflexões e tomadas de decisão com relação a práticas de sala de aula orientadas para a tentativa de se promover interações produtivas para a aprendizagem e ideais educacionais.

Caminhando nesse sentido, desenvolvemos uma proposta de um referencial teórico-prático que procura contribuir para o preparo ou analise de aulas e que pode ser criticado e desenvolvido em futuros trabalhos. Esse referencial se baseia nas três 
instâncias da interação, quais sejam, a constituição dos sujeitos e a reverberação de seus efeitos de presença; a socioafetiva, e a (meta)cognitiva. Atravessando essas três instâncias, consideramos que a quantidade e a variedade da interação não coincidem com a quantidade e a variedade das ações requeridas nas tarefas, mas sim com a complexidade das relações entre as três instâncias que descrevemos. Além disso, levamos em conta que a interação não é diretamente apreensível e que podemos apenas observar seus efeitos e elementos de sua latência. Finalmente, é preciso ter em mente que o referencial não procura evidenciar maior e menor, ou melhor e pior interação, mas sim evidenciar os elementos em jogo.

A partir do exposto, inicialmente poder-se-ia conceber o referencial em três esferas ou instâncias: quantidade, variedade e qualidade da interação. A esfera da quantidade trataria do quanto o aluno é implicado em ações e da quantidade de ações que ele realiza. Qualquer ação que o aluno realize na aula se enquadraria nesse referencial - escrever, ouvir, discutir, completar, formar, marcar, etc. A segunda esfera, a da variedade, como o próprio nome anuncia, trataria dos tipos diferentes de ação na aula; se os tipos de ação que o aluno realiza são variados ou não. O último, o da qualidade, atravessaria e retomaria os outros dois referenciais, constituindo-se por quatro elementos: a relevância, o socioafetivo, o sensorial e o (meta)cognitivo.

Essa ideação, no entanto, tem pelo menos três pontos de fragilidade teórica. O primeiro deles diz respeito à instância da quantidade. Quando consideramos, por exemplo, uma conversa por chat de texto, a quantidade de eventos (talvez o número de mensagens de texto enviadas) está associada ao potencial da interação porque claramente tem um papel fundamental na constituição de efeitos de presença. A percepção de efeitos de presença mais intensos está relacionada ao maior número de mensagens em um dado intervalo de tempo, porque, nesse exemplo, o texto enviado coincide com a materialidade da presença nesse espaço virtual que se constitui justamente pela conexão entre aqueles no chat. Por outro lado, o mesmo não se aplica no caso de uma atividade de leitura. Por ter menos ações, seria a leitura de um livro menos interativo do que uma conversa via chat? Não necessariamente. A leitura também pode nos constituir lá onde tudo está e acontece, junto com personagens e presenciando os eventos. A concepção de uma esfera da quantidade está claramente equivocada já que o número de ações só importa na medida em que é essencial na percepção de sua própria e da presença do outro. Dessa forma, são 
os efeitos de presença (e as relações de poder-saber implicadas) que constituem uma instância da interação.

O segundo ponto de fragilidade teórica diz respeito à suposta instância da variedade, que seria um dos vieses que justificaria e sustentaria o dinamismo como característica da melhor ou maior interatividade. Se nos perguntarmos "variedade do quê?", e nossa resposta for "ações", somos remetidos a um problema similar ao que acabamos de discutir. Seria uma aula de ginástica aeróbica, com uma diversidade de exercícios, necessariamente dotada de melhor ou maior interação do que uma sessão de contação de histórias, cuja variedade de ações se resume a narrar, gesticular e verbalizar onomatopeias? A variedade de ações não contempla, por exemplo, a complexidade do processo de identificação ou contra-identificação com os personagens, da inferência de sentidos a partir dos gestos, hesitações e entonações, ou da imaginação das situações e as sensações que elas suscitam. A variedade não importa como quantidade de diferentes ações e sim como complexidade de relações que podem se estabelecer entre o sujeito, sua alteridade, as diversas modalidades de sentido e operações (meta)cognitivas.

O terceiro ponto é a questão da qualidade, particularmente em seu aspecto sensorial. Por coerção do discurso neoliberal, talvez sejamos levados a argumentar que não vivemos o mundo apenas com os olhos, ou apenas com os ouvidos, ou qualquer outro sentido isoladamente e que vivemos o mundo, ou melhor, nós sentimos o mundo com tudo o que temos e que somos, sem controle total sobre nossas opiniões, nossos sentimentos e gostos, nem sobre grande parte do que aprendemos e lembramos. É um argumento sedutor porque, ainda que possivelmente de forma fragmentada, contempla (a) teorias ambientalistas do desenvolvimento e as associações diretas na formação do comportamento, (b) a fase sensório-motor de desenvolvimento, e (c) o fato de sermos atravessados pelo inconsciente. O argumento também ajudaria a sustentar, por exemplo, que experiências de imersão em ambiente virtual são mais interativas. No entanto, a experiência sensorial não acontece à parte ou fora da linguagem. A experiência sensorial não é apenas aquilo que atravessa nossos cristalinos e impressiona nossas retinas; que estimula os corpúsculos e as terminações nervosas da nossa pele, as papilas da nossa língua, ou os cílios da nossa mucosa nasal; ou aquilo que faz nossa membrana timpânica vibrar. Nós atribuímos sentidos a essas sensações e são os esses sentidos que colocam nossa experiência 
sensorial em relação a construção e projeção de quem somos, o que fazemos e o que acontece conosco. Assim, são as modalidades de sentido (imagens, textos, símbolos, texturas, disposições espaciais, sons, etc.), e não exatamente nosso sistema sensorial, que constitui um elemento do que poderia ser chamado de instância de qualidade.

Por termos argumentado contra a quantidade e a variedade, e por condição teórica, não pode haver uma instância de qualidade de interação, porque nada escaparia a ela. Conforme exposto anteriormente, propomos assim outras três instâncias da interação, quais sejam:

- a reverberação dos efeitos de presença na atualização do sujeito

- socioafetiva e identitária

- (meta)cognitiva

Para melhor se coadunar com objetivos educacionais, elevamos essas instâncias a um patamar crítico e, pelo referencial ser um ponto de partida para reflexão e tomada de decisão, optamos por desenvolvê-lo com perguntas. 


\section{Figura 7: referencial teórico-prático da interação em sala de aula}

\section{- Em quais modalidades de sentido o aluno se expressa e interpreta sentidos?}

- De que maneiras a intervenção dos alunos contribui para um produto ou evento? Os "fazeres" coincidem com seus objetivos ou há algo a ser solucionado, conquistado ou produzido por esse fazer?

- De que forma as intervenções dos alunos se relacionam umas com as outras? A atividade é individual, colaborativa ou competitiva? Os fazeres se completam, se articulam ou competem entre si?

- Quais são as relações de poder-saber que se estabelecem entre os alunos e entre eles e o professor? Há espaço entre os alunos para tomada de decisão e negociação?

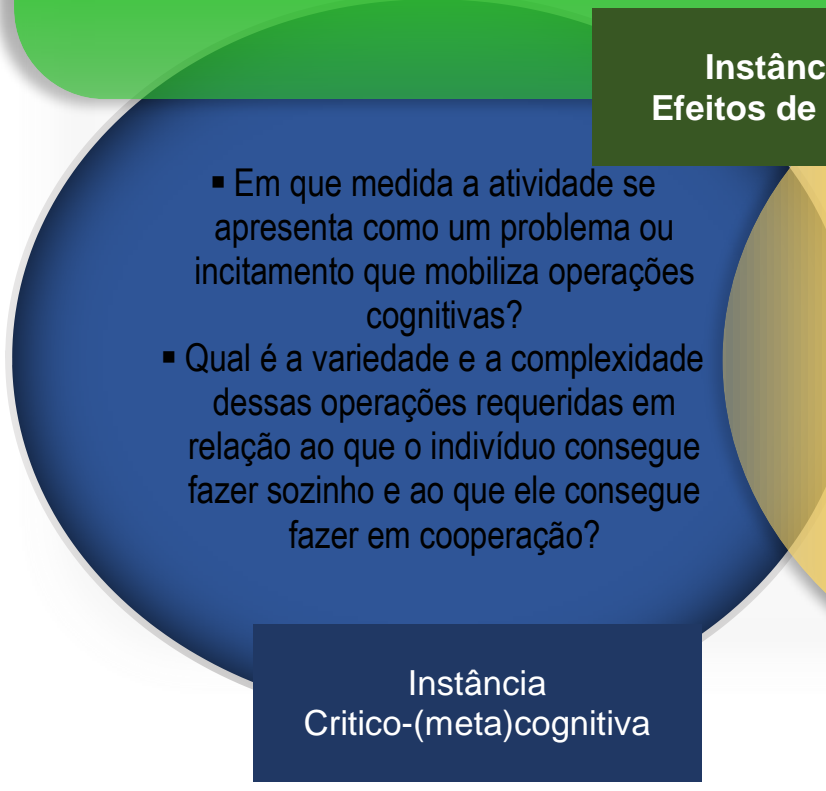

\section{Instancia dos \\ feitos de Presença}

Também é possível descrever um referencial mais genérico que possa servir como um primeiro momento de análise da interação, menos específico, e com foco nas relações e seus efeitos mais amplos:

\section{Figura 8: referencial teórico-prático simplificado da interação em sala de aula}

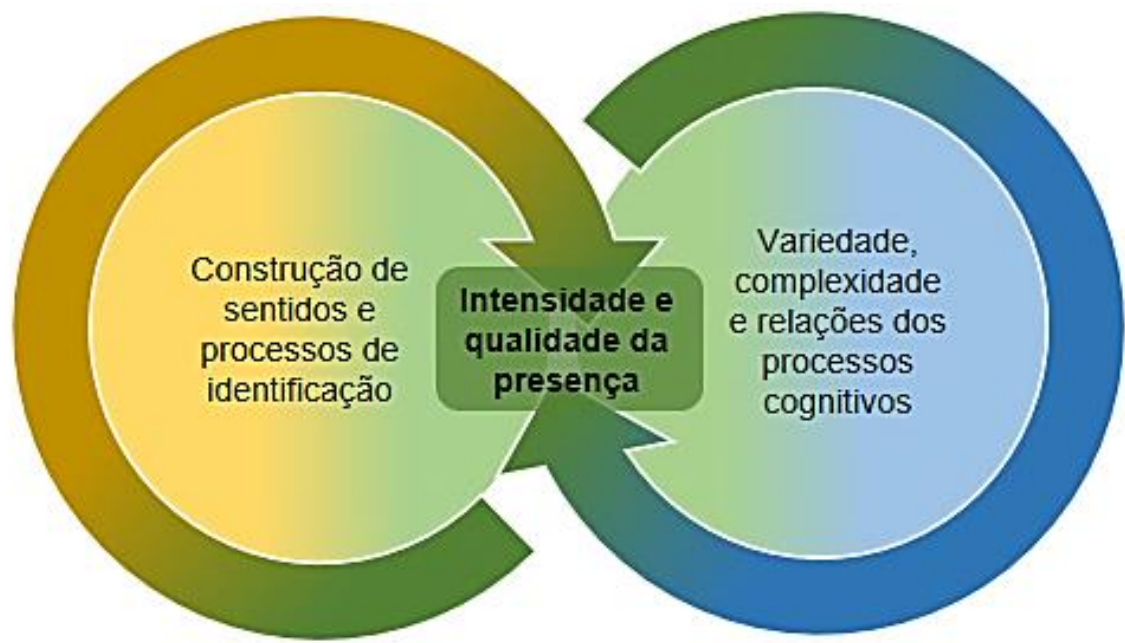


A partir do exposto e dessas representações do referencial teórico prático, algumas observações devem ser feitas:

- Levando à cabo o conceito de interação que defendemos, é possível concluir que não há aprendizagem passiva. Se a interação é pressuposta na constituição da presença, no estar no mundo e constituição do sujeito, a aprendizagem pode ser mais ou menos explícita, mais ou menos crítica, e mais ou menos reprodutora. Passivo não descreve precisamente nenhuma forma de aprendizagem porque pressupõe que o sujeito possa se constituir como um receptáculo inerte. A interação já é uma relação, de forma que falar em interação ativa é um pleonasmo. Combater a aprendizagem passiva é lutar contra o nada, ou mais exatamente, é ceder às inflexões neoliberais para que sigamos engajados às atividades que se convenciona chamar de ativas (que talvez sejam aquelas que também chamaríamos de lúdicas, dinâmicas e críticas). O processo de automatização de uma determinada função comunicativa via repetição condicionada, por exemplo, pode ser menos crítico e mais reprodutor, mas certamente não é passivo.

- As coisas, os objetos com os quais interagimos também não são passivos na interação. Seus affordances não são potenciais, são virtualidades; eles portanto são acontecimentos que entram em relação com as ações sob o objeto. As coisas não exatamente pensam, reagem e solucionam problemas, por exemplo, mas nosso engajamento com as ferramentas, tecnologias, e o ambiente é um engajamento com uma alteridade que pensa, reage e soluciona problemas.

- A chamada presença "física" não é menos virtual que aquela no meio eletrônico.

- Interatividade não é uma qualidade, uma condição, nem qualquer outra coisa contida na ação. A interação é algo entre ações e cujo efeito, portanto, não necessariamente coincide com os efeitos das ações.

- Se as ações não são apenas aquilo que se vê, se elas reinvidicam sentido, e se o conhecimento é construído na linguagem, que tem papel fundamental no processo de resolução de problemas (VYGOTSKY: 1978), a interação é a relação entre o sujeito, sua alteridade, as diversas modalidades de sentido (imagens, textos, símbolos, texturas, disposições espaciais, sons, etc.), e as operações (meta)cognitivas.

Vejamos um exemplo de uso do framework, com um plano de aula: 


\section{CLASS PLAN "TYPES OF BREAKFAST" (seven-year-old students)}

\begin{tabular}{|c|c|c|c|}
\hline \multicolumn{2}{|l|}{ DESCRIPTION } & \multirow{2}{*}{ MATERIAL } & \multirow{2}{*}{ TIME/GROUPINC } \\
\hline TEACHER & STUDENTS & & \\
\hline $\begin{array}{l}\text { Display a picture of some children having breakfast. Ask students questions } \\
\text { about the picture, e.g., "Is it morning, afternoon or night?", "Are they having } \\
\text { breakfast, lunch or dinner?". }\end{array}$ & $\begin{array}{l}\text { Students answer the teacher's questions. They are to say } \\
\text { "morning" and "breakfast". }\end{array}$ & $\begin{array}{l}\text { Picture of children having } \\
\text { breakfast }\end{array}$ & 1'-Open group \\
\hline $\begin{array}{l}\text { Review the vocabular related to breakfast, showing pictures and miming. After, } \\
\text { give students the pictures and ask them to group the different types of food } \\
\text { according to what they think they have in common, so they can find out which } \\
\text { type(s) of food they like the most. Help them asking leading questions if } \\
\text { necessary. Show them some categories of food (grain, vegetables, dairy, fruit, } \\
\text { etc.) and ask them to compare with their own. Ask the groups to try to guess } \\
\text { each other's categories of food. }\end{array}$ & $\begin{array}{l}\text { Individually, students look at each picture and pay } \\
\text { attention to the miming to say the corresponding word. } \\
\text { As a group, students negotiate to sort out the flash cards } \\
\text { and form groups of food. They try to guess each other's } \\
\text { categories and, lastly, they compare their categories with } \\
\text { the ones showed by the teacher. }\end{array}$ & $\begin{array}{l}\text { Flashcards: Coffee, Cereal, } \\
\text { Bread, Cheese, Tea, Milk, } \\
\text { Orange Juice, Fruit, Toast, } \\
\text { Egg, Butter, Cookies, Jam }\end{array}$ & $12^{\prime}$ - Whole class \\
\hline $\begin{array}{l}\text { GAME: DO YOU LIKE TEA? Stick the food flashcards on each student's } \\
\text { forehead in a way that they can't see which picture they have on them. Ask } \\
\text { them to find out who they are asking "do you like...?". Model the activity. }\end{array}$ & $\begin{array}{l}\text { Students walk around the room asking each other "Do } \\
\text { you like ...?", using the vocabulary related to breakfast. } \\
\text { They should answer "Yes, I do" when the word matches } \\
\text { the picture, and "No, I don't" when it doesn't. }\end{array}$ & Food flashcards & 10' - Cocktail \\
\hline $\begin{array}{l}\text { ACTIVITY: MAKING MY OWN BREAKFAST. Give each student a set of cards } \\
\text { with breakfast items. Include "coffee with milk", "tea with milk", and "bacon". } \\
\text { Explain the task. Model the activity. }\end{array}$ & $\begin{array}{l}\text { Students choose the items they like having for breakfast } \\
\text { and glue them on the picture of a table. }\end{array}$ & $\begin{array}{l}\text { Individual sets of food } \\
\text { pictures, pictures of table, } \\
\text { glue }\end{array}$ & 10' - Individual work \\
\hline $\begin{array}{l}\text { ACTIVITY: MAKING BREAKFAST FOR THE CLASS. The teacher explains } \\
\text { and models the activity. }\end{array}$ & $\begin{array}{l}\text { Students discuss and negotiate which items they are } \\
\text { going to put on the class' breakfast table. They have to } \\
\text { agree on a maximum of } 6 \text { items. }\end{array}$ & $\begin{array}{l}\text { A table, plastic objects } \\
\text { (cheese, bread, milk, fruit, } \\
\text { etc.) }\end{array}$ & $10^{\prime}$ - Group work \\
\hline $\begin{array}{l}\text { Show Ss some flags and check if they recognize them. Then, show some } \\
\text { pictures of breakfast and assign the task. Encourage students to compare their } \\
\text { breakfast to the ones presented in the pictures. Ask them if they would try } \\
\text { these different types of breakfast. }\end{array}$ & $\begin{array}{l}\text { Students analyze the pictures and decide where people } \\
\text { have each breakfast. Students might compare the } \\
\text { differences. }\end{array}$ & $\begin{array}{l}\text { Pictures of breakfasts of } \\
\text { different countries, different } \\
\text { flags }\end{array}$ & 5 ' - Whole class \\
\hline
\end{tabular}




\section{De quais formas a aula requer a presença dos alunos?}

Os alunos precisam responder à pergunta do professor sobre a imagem; agrupar e associar os vocabulários referente aos grupos alimentares; participar do jogo, perguntando e respondendo sobre os flashcards; decidir sobre o que gostam/não gostam para montar suas mesas de café da manhã; discutir e negociar uns com os outros sobre quais itens incluir no café da manhã da turma; e, por fim, reconhecer as bandeiras e associar quais tipos de café da manhã são tradicionais de qual país, comparando seus próprios gostos com os de outros lugares/culturas. A aula requer que os alunos frequentemente atuem uns sobre os outros e manipulem os objetos, reconhecendo as pessoas e as coisas, negociando percepções e opiniões, e tomando decisões individual e coletivamente. As atividades são constantes, sequenciadas, e envolvem uma variedade de modalidades de linguagem e de operações cognitivas, o que pode ser particularmente desafiador para crianças de 7 anos.

\section{Em que medida as intervenções dos alunos contribuem para um produto ou evento e como elas se relacionam umas com as outras?}

As atividades frequentemente preveem que a intervenção dos alunos produza a percepção de algo construído por eles, seja uma decisão ou algo tangível, sendo que esse algo passa a ser o ponto de partida para outra atividade. Por exemplo, na atividade em que os alunos associam palavras e grupos de palavras de forma a encontrar o que cada item tem em comum com o outro, sendo que eles podem fazer associações, contrastar, agrupar e hierarquizar sentidos, as ações não têm um fim em si, já que a proposta é que os alunos possam usar o processo de agrupar como oportunidade para tentativas de generalização sobre seus gostos em relação aos alimentos. Isso também pode ser particularmente desafiador para crianças de 7 anos. No jogo Do you like tea?, é através das respostas que os colegas dão que os alunos são capazes de adivinhar qual flashcard está com eles. Sem essa intervenção, o objetivo do jogo não é alcançado. Ou seja, fazer perguntas não tem um fim em si, mas servem ao propósito de ajuda-los na solução do jogo. Na atividade em que os alunos criam suas próprias mesas de café da manhã, os alunos precisam decidir o que gostam e o que não gostam dentre os itens que receberam. Para tanto, há um processo de decisão individual, o que torna o produto final da atividade variável de acordo com os gostos particulares dos alunos e dentro de um certo limite de opções. 
$\mathrm{Na}$ atividade em que os alunos criam uma mesa de café da manhã para a turma, a intervenção dos alunos também contribui para o produto final, na medida em que eles têm de negociar e coletivamente encontrar uma solução que melhor acomode seus gostos individuais com as limitações impostas: há uma única mesa e um limite de itens para eles escolherem. A última atividade talvez tenha um menor potencial para percepção de que a intervenção dos alunos tem um fim que não coincida com a ação empreendida, no sentido de que cada café da manhã é de um país específico, ou seja, há apenas uma resposta possível e o objetivo é chegar a essa resposta. Na maior parte das atividades os alunos são convidados a se articularem, e em muitas delas são convidados a negociarem e tomarem decisões coletivamente, o que significa que há diversos momentos previstos em que o conflito é explorado por seu potencial produtivo.

\section{Quais são as relações de poder-saber (power-knowledge) que se estabelecem entre os alunos e entre eles e o professor?}

Essa sequência de atividades não posiciona o professor como fonte exclusiva do saber, mas mantém uma ordem hierárquica na qual ele é aquele que determina o que deve ser feito. Os alunos não têm muito espaço para decidirem o que fazer. Ao mesmo tempo, as atividades preveem oportunidades para que os alunos negociem e tomem decisões entre si com pouca intervenção por parte do professor. Há espaço para que os alunos argumentem, se imponham, resistam, disputem, consintam, aprovem, reprovem, briguem, etc. Esse espaço não é algo paralelo ou secundário, já que em diversos momentos está no centro do que é necessário para a resolução das atividades. A atividade de montar o café da manhã da classe, mais claramente, promove uma situação de resolução de conflito, uma vez que os alunos precisam negociar quais itens incluir e quais deixar de lado. Como os gostos e preferências podem ser variados, precisam ajustar suas expectativas, impor-se ou ceder à vontade do outro, criar critérios ou um sistema (por exemplo, votação), e lidar com a possibilidade de haver alunos que se sintam menos representados no consenso coletivo. Isso pode ser particularmente desafiador para crianças de 7 anos, e contribuir para seu desenvolvimento operatório e percepção menos egocêntrica. 


\section{Em que medida a atividade promove a desnaturalização e desneutralização do} mundo?

As atividades em que os alunos precisam negociar suas preferências e a última atividade, na qual são apresentados cafés da manhã de diferentes países, podem levar os alunos a percepção de que os alimentos não são intrinsicamente gostosos ou ruins, a partir da reflexão sobre o fato de que as pessoas podem gostar e comer coisas diferentes no café da manhã. Ao serem expostos a culturas onde as pessoas comem feijão, salsicha e chá com leite, por exemplo, são levados a olharem para o mundo como novos olhos, a perceberem que nem tudo é igual à realidade deles e que devem respeitar as diferenças de opiniões e costumes.

Em que medida a atividade se apresenta como um problema ou incitamento que requer operações cognitivas e qual é a variedade e complexidades dessas operações em relação ao que o indivíduo consegue fazer sozinho e ao que ele consegue fazer em cooperação?

Quase todas as atividades se apresentam como situações-problema que requerem diversas e variadas operações para sua solução: reconhecer, identificar, compreender, inferir, fazer associações, contrastar, organizar, agrupar, avaliar, relacionar, etc. A maior parte dessas operações são típicas do período operatório concreto do desenvolvimento infantil, de acordo com Piaget (RAMOZZICHIAROTTINO, 1984; e PIAGET, 1970), e que podem ser ainda pouco amadurecidas em crianças de 7 anos. Devido à importância da linguagem e da fala na cognição de resolução de problemas, de acordo com Vygotsky (1978), é possível sustentar que o fato dessas situações requererem a discussão, a negociação e a articulação das crianças torna as situações-problema menos desafiadoras.

\section{Em quais modalidades de sentido a atividade convida 0 aluno a interpretar,} negociar, refletir e atuar?

Os alunos precisam interpretar imagens (ao associar imagens a itens lexicais e ao interepretar as imagens dos cafés da manhã típicos de alguns países) e palavras, ouvir as perguntas dos colegas para poder respondê-las (no jogo Do you like tea?), e negociar com os colegas observando as imagens dos itens de café da manhã. Além disso, as atividades exploram modalidades sensoriais, ao requerem que os alunos 
andem pela sala e colem os itens de café da manhã na mesa, por exemplo. Ou seja, interpretam e constroem sentidos nas modalidades verbal, auditiva, escrita, visual, táctil e espacial, frequentemente lidando com atividades multimodais.

\section{Em que medida a atividade procura promover a compreensão do sujeito sobre} - lugar e a(s) posição(ões) de onde fala e sobre como seu lugar e sua(s) posição(ões) o incluem e excluem de certas práticas sociais e impõem condições de interpretação e opinião?

Nas atividades em que os alunos precisam negociar suas preferências e na última atividade, na qual são apresentados cafés da manhã típicos de diferentes culturas, além dos alunos poderem perceber que os alimentos não são intrinsicamente gostosos ou ruins, podem levar os alunos a perceber que parte do que significa sem quem eles são também tem relação com o que eles gostam e não gostam de comer. Eles podem pensar, por exemplo, que talvez gostassem de feijão doce no café da manhã, se fossem ingleses, ou de salsicha se fossem alemães. Podem decidir, por exemplo, experimentar esses alimentos. Podem ainda achar que nunca vão gostar desses deles justamente porque são típicos de pessoas em culturas muito diferentes. Conforme dissemos anteriormente, ao serem expostos a culturas onde as pessoas comem feijão, salsicha e chá com leite, por exemplo, são levados a olharem para o mundo como novos olhos, a perceberem que nem tudo é igual à realidade deles e que devem respeitar as diferenças de opiniões e costumes. O professor pode contribuir para a promoção de tal reflexão ao fazer perguntas, como: Você já comeu feijão doce no café da manhã? Você conhece alguém que come? Do que você mais gosta no café da manhã? Você conhece alguém que também gosta? Você acha que alguém que gosta de feijão doce no café da manhã gostaria do que você gosta? Por quê? Você tomaria chá com leite? Conhece alguém que tomaria?

\section{Conclusões}

Ao pesquisar e fazer um estudo bibliográfico sobre o tema da interação e interatividade, apesar da complexidade da produção de conceitos, alguns caminhos reflexivos parecem ter mais destaque e apontar para nós teóricos em comum. Alguns trabalhos romantizam a interativid bade, tratando-a como algo que garante uma 
infinidade de possibilidades. Outros idealizam os dois termos (interação e interatividade), como se fossem necessariamente dois termos eufóricos: será que alguém ousaria dizer que uma aula interativa não é boa? Ao mesmo tempo, é como se interatividade fosse necessariamente algo positivo, independentemente do que aconteça. Outros ainda traçam implicações desses conceitos para a sala de aula, delineando os papéis dos agentes educativos, alunos, professores e instituições.

A interatividade não pode ser desvinculada das relações conflituosas constitutivas da presença. Mas os discursos sobre a conectividade que as novas tecnologias da cibercultura proporcionam contribuem para formações ideológicas nas quais a interação e, principalmente, a interatividade são idealizadas e exacerbadas com qualidades puramente positivas. Essa romantização é improdutiva e obscurece a prospecção de práticas alternativas. Defendemos que há uma esfera virtual da presença que de fato é anterior a interação, mas aquilo que frequentemente é nomeado "presença", os efeitos de presença, é efeito da interação. Ou seja, a presença é condição e, ao mesmo tempo, produto da interação, de forma que a qualidade da interatividade não possa ser dissociada da qualidade da percepção da presença.

Nossa perspectiva procura abordar essas "qualidades" da interação respondendo criticamente às armadilhas das qualificações mercadológicas neoliberais. Devemos evitar tratar o aprendizado e o conhecimento como frutos, mas sim como frutíferos, e reconhecer o potencial criativo e produtivo no conflito que é inerente à interação, compreendendo o conflito como encontro que produz estados de coisas e acontecimentos. É preciso, enfim, questionar o tratamento da interatividade como fluxo de ações (exclusivamente) positivas, cujo fruto seria o aprendizado. Esse tratamento faz com que a interatividade seja uma passividade; um reprodutivismo: toma a interação como realização ${ }^{40}$ da presença e do aprendizado, como algo da ordem das substâncias ou como acontecimento que não remonta a nenhuma instância problemática $^{41}$.

A interação ou qualquer coisa que possamos dizer que seja interativa, apesar da heterogeneidade das definições que apresentamos, é alvo de um processo de pasteurização. Conforme discutimos, tanto no discurso acadêmico como no senso

\footnotetext{
40 No sentido deleuziano.
}

41 No sentido deleuziano. 
comum, a interação é exaltada como algo que deve ser sempre harmonioso e prazeroso, escamoteando as características de conflito e tensão que são constitutivos da interação. Grande parte de seu potencial criativo está exatamente nos processos de resolução e negociação de conflitos e tensões.

A reflexão a partir do framework deixa entrever que não existe aula que não seja interativa, se tomarmos interação em seu sentido mais crítico. O trabalho com o framework não busca usar uma mensuração da interação para rotular a boa ou a pior aula ou ainda distinguir a aula produtiva e da improdutiva. Ele nos ajuda, porém, a compreender os elementos interativos que possam de fato entrar em jogo em uma dada sala de aula, já que os maiores potenciais e as limitações das sequências didáticas dependem disso. Em última instância, a reflexão sobre as instâncias da interação contribui para a construção de aulas interativas dentro do que consideramos que seja mais produtivo para a aprendizagem de uma língua e para objetivos educacionais. 


\section{Capítulo 4}

\section{REGRAS DE DISPERSÃO DO DISCURSO DA MídIA PUBLICITÁRIA}

O objetivo deste capítulo é refletir a respeito da formação do discurso da mídia publicitária sobre a interação em cursos de inglês, em uma perspectiva foucaultiana (FOUCAULT, 1969/2009), descrevendo as regularidades de sua dispersão nos quatro níveis (objetos, tipos enunciativos, conceitos e temas e teorias) e se concentrando no nível do conceito (de interação). Não pretendemos aplicar a metodologia arqueológica foucaultiana, como também não faremos uma desconstrução ou crítica dessa metodologia por suas limitações estruturalistas. Alternativamente, procuramos nos apropriar dessa teoria arqueológica, sem perder de vista o conjunto e a lógica de pensamento foucaultiano, e colocá-la em relação com o pensamento deleuziano. Dessa forma, as limitações estruturalistas da visão arqueológica não se tornarão pontos de implosão conceitual, mas sim pontos de crise que elevam a teoria a outro nível. Segundo Deleuze, o conjunto do pensamento foucaultiano é "aquilo que o força a passar de um nível ao outro" (1992/2010, p. 110) e "a lógica de um pensamento é o 
conjunto das crises que ele atravessa, assemelha-se mais a uma cadeia vulcânica do que a um sistema tranquilo e próximo do equilíbrio" (Idem).

Aqui, a arqueologia não necessariamente precisa dar lugar à genealogia, pois aquela traz em si uma latência genealógica. Quando Foucault argumenta que não são os elementos, mas sim a relação entre eles que se faz constante, não significa que ela deva ser vista como uma sobredeterminação de um sistema de rarefação e dispersão. Essa relação é ela própria sujeita aos dispositivos e exercícios de poder ${ }^{42}$ que se constituem e estabelecem em um dado momento histórico. Em um jogo de relações entre coisas (saber) e entre ações (poder) (DELEUZE, 1986/2005), a arqueologia anuncia a genealogia ao apresentar-lhe seu problema.

Nesse sentido, seria pouco produtivo para nossos objetivos fazer uma arqueologia do discurso da mídia publicitária ou procurar explicitar as insuficiências do método arqueológico para então propor uma perspectiva que viesse a suprir tais insuficiências. Partimos da teoria arqueológica foucaultiana e de uma leitura deleuziana da obra de Foucault para fazer uma reflexão teórica sobre a noção de formação discursiva e suas leis de dispersão, não apenas discutindo as regularidades do discurso da mídia publicitária sobre a interação em cursos de inglês em escolas livres, mas também procurando as linhas de fuga dessas regularidades que nos permitam apreender mais profundamente o funcionamento do discurso da mídia publicitária.

De saída, quando dizemos "o discurso da mídia" é preciso ter claro que "a mídia" não oferece nem constitui nenhum elemento ou princípio de unidade de discurso em uma perspectiva foucaultiana. Para o autor (1969/2009), os discursos devem ser analisados como dispersão porque não têm princípios de unidade e, nessa análise, é possível apreender regularidades que funcionam como lei de dispersão, ou seja, que estabeleçam sistemas de dispersão entre os elementos do discurso. Tratase de formular regras capazes de reger a formação dos discursos, às quais Foucault chama de "regras de formação" (1969), e que, portanto, explicam como os discursos se produzem e se distribuem.

\footnotetext{
42 Preferimos exercício de poder ao invés de relações de poder, nesse caso, por uma questão de paralelismo, levando em conta que "a força nunca existe no singular, pertence a sua essência estar em relação com outras forças, de tal modo que qualquer força é já relação, ou seja, poder." (DELEUZE, 1986/2005, p. 97).
} 
Para explicar como e por que podemos falar, por exemplo, "do discurso clínico, do discurso econômico, do discurso da história natural, do discurso psiquiátrico" (FOUCAULT, 1969/2009, p. 122), o autor formula quatro hipóteses. A primeira é que "os enunciados, diferentes em sua forma, dispersos no tempo, formam um conjunto quando se referem a um único e mesmo objeto" (p. 36). A segunda é que a forma e o tipo de encadeamento, ou seja, as modalidades enunciativas podem definir ou caracterizar um grupo de relações entre enunciados. A terceira hipótese é que grupos de enunciados poderiam se estabelecer na medida em que lhes forem determinados um sistema dos conceitos permanentes e coerentes. A quarta hipótese de Foucault é que o agrupamento dos enunciados poderia ser feito ao "descrever seu encadeamento e explicar as formas unitárias sob as quais eles se apresentam: a identidade e a persistência dos temas" (p. 40).

Foucault formula, analisa e rejeita as quatro hipóteses, como eixos isolados e argumenta que as regras de dispersão só podem ser aprendidas na relação entre esses eixos. Nessa esteira, trataremos de cada um dos quatro elementos da formação do discurso da mídia publicitária, mas também das relações entre esses elementos.

\section{A formação dos objetos}

O autor questiona a unidade do discurso em um "domínio de objetos cheio, fechado, contínuo e geograficamente bem recortado" (FOUCAULT, 1969/2009, p. 42). O autor conclui que os objetos são lacunares, descontínuos, múltiplos e que não são inteiros, tampouco podem ser dados a priori. Nesse sentido, o que faz a unidade de um discurso não é o objeto ao qual ele se refere. É o objeto que se forma pelo que se disse a seu respeito.

Para Foucault (1969/2009, p. 49), é o "conjunto de relações estabelecidas entre instâncias de emergência, de delimitação e de especificação" que define o objeto de uma formação discursiva. É importante destacar o termo "relações" usado por Foucault. Essas relações não são internas, nem externas ao discurso. Elas não são meras ligações entre palavras, frases, proposições em uma espécie de arquitetura discursiva; tampouco são forças ou circunstâncias externas que se imporiam ao discurso, determinando sobre o que se pode falar. Essas relações estão no limite do 
discurso, condicionando feixes de relações discursivas que permitem falar deste ou daquele objeto (FOUCAULT, 1969/2009, p. 51).

É sob essa perspectiva que analisamos a formação do(s) objeto(s) do discurso da mídia publicitária sobre interação em cursos de inglês, demarcando as superfícies de sua emergência, descrevendo suas instâncias de delimitação e explicitando suas grades de especificação ao mesmo tempo em que tecemos relações entre esses três aspectos.

O discurso da mídia publicitária pode ter como superfícies de emergência ou seja, os campos de diferenciação que permitem que um objeto seja nomeável e descritível - o indivíduo, o capital, a identidade, a autonomia, a liberdade, o prazer, o bem material, o bem simbólico, o valor, o global, o desejo, o trabalho, a prestação de serviço, o consumo, e a propriedade privada. Como se relacionam, por exemplo, as práticas de ser dono de algo, de consumir alguma coisa, de desejar a liberdade e 0 prazer e de querer ser único? Qual é o funcionamento da prática de ser possível ter posse de uma ideia ou conhecimento, e da institucionalização da identidade? Não se pergunta quais indivíduos querem consumir, mas sim quais indivíduos podem consumir, e o que, por que, como, e quando eles querem consumir. É no feixe de relações dessas superfícies que o discurso da mídia publicitária nomeia e descreve seu objeto: a mercadoria.

As instâncias de delimitação sobre esse objeto são as emissoras de TV, a publicidade, o marketing, os publicitários, os órgãos de regulamentação da comunicação, o código de defesa do consumidor, a indústria, o comércio, os prestadores de serviço, as instituições sem fins lucrativos, o governo, e o consumidor. O conjunto dessas instâncias é constituído por instituições que regulamentam práticas de venda e consumo, por corpo de profissionais especialistas legitimados e por áreas de saber. Esse conjunto distingue, nomeia, designa e estabelece aquilo que circula para ser vendido e consumido.

Já o mercado, como eixo de demandas e complexo de características, se constitui como grade de especificação, já que funciona como organismo que distingue e associa os diferentes tipos de mercadoria como objetos do discurso publicitário. As separações, definições, oposições, derivações, classificações e agrupamentos dos diferentes tipos de mercadoria não são aleatórios. 
São essas as relações (entre instituições, comportamentos, práticas, etc.) que permitem a formação do objeto da mídia publicitária. Ela não fala senão da mercadoria. Entre os tipos de mercadoria, está o curso de inglês. Ou ainda, a fluência em inglês. Toma-se aprendizagem por aprendizado, já pronto para o consumo.

Não se deve ver aí algum tipo de maquinação, trama, manipulação, conluio ou conspiração de um indivíduo, uma coletividade, uma instituição ou conjunto de instituições que, tendo controle total sobre seu dizer, decide constituir a fluência em inglês como uma mercadoria e reproduzir esse discurso por meio de um mecanismo opressor do "novo" ou da subversão. O discurso da mídia publicitária é tão sujeito quanto qualquer outro à ordem do discurso. Conforme Foucault,

As condições para que apareça um objeto de discurso, as condições históricas para que dele se possa 'dizer alguma coisa' e para que dele várias pessoas possam dizer coisas diferentes, as condições para que ele se inscreva em um domínio de parentesco com outros objetos, para que possa estabelecer com eles relações de semelhança, de vizinhança, de afastamento, de transformação (...) são numerosas e importantes. Isso significa que não se pode falar de qualquer coisa, a qualquer tempo; não é fácil dizer alguma coisa nova (...). (1969/2009, p. 50).

O objeto não é dado e anterior ao discurso. Ele se constitui nas práticas mesmas de se falar dele. O discurso publicitário fala sobre a fluência em inglês submetido a um eixo de relações que exercem um jogo de coerção. Segundo Deleuze, "o enunciado não remete para nenhum cogito ou sujeito transcendental que o tornaria possível, nem para um eu que o pronunciaria pela primeira vez (...). É certo que há "lugares" de sujeito para cada enunciado" (1986/2005, p. 15) e que "indivíduos diferentes podem neles entrar" (idem).

Ao mesmo tempo, também não se deve ver aí uma instância determinística, como se essa fosse a única forma possível desse objeto. Conforme Foucault, não são constantes os objetos, nem o domínio que os formam e tampouco a sua caracterização. A relação entre as superfícies onde os objetos podem surgir, ser delimitados, e ser especificados, ao mesmo tempo em que exerce coerção, necessariamente constitui a potência de uma resposta criativa submetida a relações de poder. Essa questão não é tratada na "Arqueologia do Saber" e geralmente é atribuída à abordagem genealógica de Foucault, mas ela não mostra exatamente uma inconsistência da arqueologia. Essa questão é uma crise necessária para constituição de um problema que a genealogia procura responder. Deleuze defende que "'A 
arqueologia' detém-se aí [reconhecer as singularidades que o enunciado pressupõe], e não tem ainda de tratar desse problema que extravasa os limites do 'saber'" (1986/2005, p. 25), e explica que "são os livros seguintes que explorarão esse domínio" (Idem).

\section{A formação das modalidades enunciativas}

A formação das modalidades enunciativas envolve as descrições, narrações, demarcações, interpretações, as verificações e muitas outras formas de enunciados e Foucault (1969/2009, p. 56) propõe três questões para explorar as relações e disposições dessas formas.

A primeira questão diz respeito a quem fala. Ou melhor, diz respeito ao status de quem fala. O publicitário recebe qualidades da singularidade de sua linguagem e, ao mesmo tempo, legitima tal linguagem. A fala da mídia publicitária define o publicitário e não pode vir de qualquer um. O publicitário é definido por um status que o permite (que dá a ele o direito de) articular a fala que estrutura a eficácia do consumo, constituindo-se em uma trama de traços, diferenciações, associações e correlações com outros status. Ao mesmo tempo em que lhe dá esse direito, o conjunto de condições que o publicitário reconhece em si e que nele é reconhecido estabelece ou fixa os limites de sua prática. O publicitário deve falar como publicitário. O status do publicitário se constitui com o papel que se reconhece nele no funcionamento de uma sociedade e na sua regulamentação (institucionalização) como profissão, envolvendo os direitos e limites das práticas desse papel. O status de quem fala ganha em complexidade no caso do discurso da mídia publicitária porque a construção da unidade de quem fala também envolve a voz institucional de quem anuncia, que deve ser pronunciada com status de publicitário.

A segunda questão, na esteira da primeira, diz respeito ao espaço institucional de onde se fala. Devemos então nos perguntar de onde o publicitário obtém seu discurso, ou ainda onde está a "origem" legítima e o acontecimento da fala do publicitário. Pela mesma lógica segundo a qual, na formação dos objetos, estes não são exatamente inerentes às coisas (não se trata de uma relação ou condição referencial), o lugar de onde se fala não remete a um sujeito cognoscente nem a uma individualidade psicológica (FOUCAULT, 1969/2009, p. 70). Trata-se de modos de 
uma "não-pessoa" ou um espaço correlativo de enunciados e seus suportes materiais com seus sujeitos, constituindo-se lugares variáveis intrínsecos ao ato mesmo de enunciar (DELEUZE, 1986/2005). Em nossa sociedade, esses locais não seriam apenas o outdoor, o comercial televisivo, o banner, o anúncio em revista ou jornal, e o comercial narrado no rádio são, mas também os hotsites, os sites, as páginas em redes sociais, o próprio navegador da internet. Assim como "uma carta vulgar remete para um signatário" (DELEUZE, 1986/2005, p. 18) ou "um contrato remete a um fiador" (idem), um anúncio em um site, um post patrocinado ou um hotsite promocional também constituem o lugar daquele que fala com o consumidor.

A terceira questão traduz-se nas diferentes posições que o sujeito que se constitui nesse lugar pode ocupar. Conforme Foucault (FOUCAULT, 1969/2009, p. 58), "as posições do sujeito se definem igualmente pela situação que lhe é possível ocupar em relação aos diversos domínios ou grupos de objetos". Esse sujeito transmite uma informação ou retrata um fato ou uma realidade; é um sujeito que busca refletir o estado emocional ou a opinião do seu interlocutor; ele busca convencer a agir, interpela seu interlocutor; é um sujeito que arquiteta sua fala de maneira que a forma de dizer seja o próprio dizer.

Essas diferentes posições não são e nunca foram estanques nem fixas, mas o estágio atual das tecnologias da comunicação e as práticas transmidiáticas dão ainda mais liquidez para as diferentes situações que podem ser ocupadas pelo sujeito do discurso da mídia publicitária. No deslizar das narrativas, sob o jogo de coerções das particularidades de cada suporte midiático e suas práticas sociais, o feixe de relações entre o status, o lugar e as posições do sujeito da mídia publicitária se reconfigura. As modalidades de anunciação que esse discurso utiliza ou às quais dá lugar não são dadas nem pressupostas; o próprio funcionamento do discurso que mobiliza os elementos de status, de lugares e posições de sujeito instaurando feixes de relações entre eles.

Não se deve, portanto, projetar o sujeito da mídia publicitária como um ardiloso, capcioso e sagaz articulador das palavras que não fazem senão obedecer ao seu comando e cumprir seu objetivo, a saber, manipular, seduzir e levar ao consumo. Insistimos, o discurso "não é a manifestação, majestosamente desenvolvida, de um sujeito que pensa, que conhece, e que o diz" (FOUCAULT, 1969/2009, p. 61). 
Por outro lado, a palavra é uma instância de poder. A interpelação e a injunção, por exemplo, ao nomear e ao comandar, são embates de potências, implicam ações sobre ações; são exercício de poder. A interpelação e a injunção sempre impõem uma relação, já que o interpelado significa sua presença, mesmo não se reconhecendo como alvo do apelo que o identifica; e que a recusa em executar um comando é em si também uma resposta à injunção. Isso significa que o outdoor, a TV, o banner, o anúncio, os sites, as redes sociais e o próprio navegador da internet constituem também dispositivos de poder.

Nesse ponto, o funcionamento das modalidades enunciativas através das mídias encontra uma articulação particularmente curiosa com o conceito da interatividade. Por exemplo, a imposição, supõe-se pelo efeito da memória dos discursos totalitários e repressores, pode ser frequentemente associada à interdição ou à proibição da ação. Mas, no caso do discurso da mídia publicitária, quanto maior a interatividade, maior é a submissão às imposições desse discurso. Trata-se de um mecanismo artificioso e de um efeito perverso. O discurso da mídia publicitária interpela, injunge, interdita, impõe, seduz e propõe em nome da interatividade e com dispositivos tais que sua eficiência é definida pelo engajamento do sujeito que se percebe mais livre, com mais opções, mais autônomo, enfim, mais interativo.

\section{A formação dos conceitos}

A formação dos conceitos não deve ser vista como uma edificação dedutiva (FOUCAULT, 1969/2009, p. 62); não pode ser reduzida a relações axiomáticas ou determinações “contextuais” (DELEUZE, 1986/2005, p. 16). Para uma análise de formação discursiva, o conceito não importa como uma implicação ou derivação de outro conceito, sendo produzido dedutivamente; tampouco como abstração de acontecimentos observáveis ou apreensíveis; mas sim

sua dispersão anônima através de textos, livros e obras; dispersão que caracteriza um tipo de discurso e que define, entre os conceitos, formas de dedução, de derivação, de coerência, e também de incompatibilidade, de entrecruzamento, de substituição, de exclusão, de alteração recíproca, de deslocamento, etc. (FOUCAULT, 1969/2009, p. 66).

Isso significa que a formação dos conceitos não é arremetida ao puro e neutro acaso, mas que compreende uma organização e movimentos lacunares e 
descontínuos do campo de enunciados. Com relação a essa organização e esses movimentos, o discurso da mídia publicitária nos propõe um problema: esse discurso não define domínios de validade, de normatividade e de atualidade, mas se apropria de domínios definidos em outras formações para dispor conceitos em relação com seu objeto, suas modalidades enunciativas e suas estratégias. Ou seja, se em outras formações trata-se de uma diagonal móvel que atravessa um espaço rarefeito de enunciados dispersos e heterogêneos, aqui trata-se de uma linha que se desterritorializa no ponto mesmo de relação com os objetos, as modalidades enunciativas e as estratégias de sua formação discursiva. A formação dos conceitos, no discurso da mídia publicitária, define-se por uma linha de fuga no quadro de relações das regras de formação desse discurso.

As formas de sucessão enunciativas, as formas de coexistência e os procedimentos de intervenção (FOUCAULT, 1969/2009) constituem práticas de apropriação conceitual no discurso da mídia publicitária. Falemos primeiramente das formas de sucessão, que compreendem a disposição das séries enunciativas, os tipos de correlação e os esquemas retóricos. No discurso da mídia publicitária, as séries enunciativas são dispostas na forma de uma sugestão, uma proposta ou uma narrativa mítica, um ou uma sucessão de acontecimentos, sem recorrer a esquemas de generalização e inferência, por exemplo. Dizemos narrativa mítica porque se trata de um princípio de organização que representa uma sequência de acontecimentos que se ligam por uma lógica causal e intemporal (um agora constante, não-histórico) e por uma rede de intensões. Qualquer que seja o caso, sugestão, proposta ou narrativa mítica, a disposição dos enunciados não é articulada para demonstrar, descrever ou deixar inferir um conceito, mas para convocá-lo de outra dimensão, desterritorializando-o de um determinado espaço discursivo e o atualizando em sua rede de relações. O discurso da mídia publicitária demonstra e descreve seu objeto, enquanto o conceito é atualizado como aquilo que o qualifica ou o sustenta. Nos textos publicitários analisados, a sala de aula de inglês é descrita, apresentada, demonstrada e sugerida ou proposta para o consumo. Interação é um conceito pressuposto dessa sugestão ou proposta porque a sala de aula onde se aprende é presumidamente interativa. A atualização do conceito no discurso da mídia publicitária o resignifica, pelas outras relações que se estabelecem, como "valor" do objeto. 
O tipo de correlação entre os enunciados é de sucessão de complementaridades ou de oposições. Diferente de correlações de hipóteseverificação ou lei geral-aplicação particular, por exemplo, a correlação de complementaridade se esquiva de procedimentos de análise e reflexão. O conceito se apresenta com a naturalidade que a condição de lugar de memória da mídia lhe atribui $^{43}$ e o status de verdade que outros discursos institucionais the conferem. As correlações de oposição ou de asserção-crítica funcionam da mesma maneira nesse discurso. A asserção é como a descrição de ontem (indesejado e ultrapassado, mas reconhecível no agora) e a crítica é a verdade de hoje (desejada e presumida como a forma correta de ser e de estar das coisas e das pessoas). A asserção é o contraexemplo de uma crítica que, na verdade, é a reiteração do lugar-comum. Não há de fato crítica.

Além de funcionar como valor, os conceitos são elementos em uma grade de fundo que é condição para as modalidades argumentativas e propositivas no esquema retórico do discurso da mídia publicitária. Esse esquema parte de um ou de uma grade de conceitos, explorando-os como memória, verdade natural ou resultado de uma experiência presumida (também naturalizada e verdadeira), em direção a estruturas enunciativas que estabelecem uma relação de influência. Essa grade funciona como o fundo ou o piso que permite que a focalização do argumento de venda que interpela, avisa, sugere e propõe. Assim como um grito corta o silêncio, um holofote atravessa o céu escuro ou uma lancha desliza pelas águas de um mar calmo, o "matricule-se agora" salta da grade de conceitos que qualificam a sala de aula de inglês. Até mesmo quando o esquema retórico qualifica ou categoriza o curso de inglês a ser vendido, são os conceitos da grade de fundo que o constituem como estruturas qualificantes, distinguidoras e individualizantes, sempre pressupostas e tomadas por certo e verdadeiro. Tal esquema retórico tem papel também decisivo da atualização do conceito em um nó de relações a serviço da promoção do objeto da mídia publicitária.

Essas formas de sucessão enunciativas enfatizam as "formas de coexistência" dos conceitos (FOUCAULT, 1969/2009) que delineiam um "campo de presença”, um "campo de concomitância” e um "domínio de memória” (Idem). No caso

\footnotetext{
${ }^{43}$ A mídia recebe um investimento simbólico que lhe atribui o papel de lembrar os indivíduos das coisas como elas são ou sempre foram.
} 
do campo de presença ${ }^{44}$, ao contrário do que ocorre no discurso científico, onde as relações tipicamente instauradas são da ordem da verificação, da experimentação, da investigação ou do comentário, por exemplo, no discurso da mídia publicitária essas relações são da ordem da repetição e da aceitação justificada pela tradição e pela autoridade. $\mathrm{O}$ campo de concomitância ${ }^{45}$ é expandido e estabelece deformidades em seu espaço de forma a atrair os enunciados em seu alcance. $O$ domínio de memória ${ }^{46}$ é reduzido ao ponto de não se distinguir do campo de presença e ao ponto de ser completamente coberto pelo campo de concomitância.

As relações de formação dos conceitos criam um espaço de gravidade absoluta que atrai enunciados formados em outras regiões do discurso. Essa atração não retira o conceito de sua formação, ou seja, não o desconecta da teia de relações de sua produção, tampouco simplesmente o duplica e toma a réplica para si. Em outras formações, os enunciados já formulados em outras partes podem ser "retomados [...] a título de verdade admitida, de descrição exata, de raciocínio fundado ou pressuposto necessário, [...] [ou] criticados, discutidos e julgados, [e] rejeitados ou excluídos" (FOUCAULT, 1969/2009, p. 63). Mas esse movimento acontece em um primeiro plano em outras formações. No discurso da mídia publicitária, a formação do conceito acontece no plano de fundo, no plano daquilo que deve ser dado, sabido e aceito generalizadamente.

Aqui, as formas de coexistência dos enunciados estabelecem com os enunciados e conceitos de outras formações mais um eixo de relação. Esse eixo é necessariamente e simultaneamente virtualizante e atualizante, porque os enunciados não são simplesmente arrastados pelo campo de presença até o espaço da mídia publicitária, mas passam por um devir produzido em um processo de desterritorialização-territorialização. Esses devires também se relacionam com os demais conceitos do campo de presença, constituindo-se, eles próprios, como um conceito ao qual outras formações devem responder. Em outras formações, os enunciados são retomados como alteridades em relação às quais algo se constitui.

\footnotetext{
${ }^{44}$ Constitui-se por "todos os enunciados já formulados em alguma outra parte e que são retomados em um discurso" (FOUCAULT, 1969/2009, p. 63) para serem reiterados, criticados ou excluídos. 45 É definido por enunciados que se referem a domínios de objetos inteiramente diferentes e que pertencem a tipos de discurso totalmente diversos, mas que atuam entre os enunciados estudados" (FOUCAULT, 1969/2009, p. 64).

46 "Trata-se dos enunciados [...] em relação aos quais se estabelecem laços de filiação, gênese, transformação, continuidade e descontinuidade histórica" (FOUCAULT, 1969/2009, p. 64).
} 
No discurso da mídia publicitária, eles são tomados e atualizados em relação a eles mesmos, porém em outra rede de relações, que lhe impõem outras condições de sentido.

Essa configuração das formas de coexistência dos enunciados tem o campo de concomitância expandido e o domínio de memória achatado. O campo de concomitância da mídia publicitária é extenso e tem um horizonte que nos faz questionar quais seriam os enunciados que não estariam ao alcance da mídia publicitária. Este campo também cresce na mesma medida em que fortalece sua relação com a formação dos objetos, já que, em uma sociedade espetacular e neoliberal como a nossa, na qual tudo é potencialmente um produto anunciável para o consumo, mesmo os enunciados de tipos de discurso diversos e que se referem a domínios de objetos distintos estão sujeitos à apropriação do discurso da mídia publicitária.

Já o campo de memória é achatado ao ponto de pouco ou nada se distinguir do campo de presença. Os laços de transformação e de continuidade-descontinuidade histórica não se estabelecem porque os enunciados tratam sempre do agora, mesmo ao falar do passado. Em um dos vídeos analisados, a sala de aula de "antes", tinha um tipo de interação sério, sóbrio e repetitivo. Mas essa ideia de interação não é de fato uma memória, mas um concomitante. É a interação da sala de aula atual de outras escolas, que não a anunciante.

\section{A formação das estratégias}

A formação das estratégias é o eixo que, em relação com os objetos, conceitos e modalidades de um discurso, permite que apreendamos certa coerência com relação à temas ou teorias (que diferem apenas com relação ao nível formal). A distinção dos níveis formais do tema à teoria não nos importa (como também, em última análise, não importaram a Foucault) porque não tratamos aqui de um discurso científico (que era o objeto de análise da "Arqueologia do Saber"). O jogo entre pontos de difração (que são pontos de incompatibilidade, de equivalência ou de ligação), instâncias de decisão e práticas não discursivas na formação das estratégias do 
discurso da mídia publicitária mostram austeramente o poder da repetição ${ }^{47}$ dos enunciados em uma curiosa articulação de suas restritas condições reais.

Nas práticas discursivas que constituem a mídia como lugar de memória, os pontos de incompatibilidade, de equivalência e de ligação produzem o efeito de uma forma ideal que se mostra sempre aqui e agora, mas não como acontecimento recente que denuncia sua ancoragem em um tempo e lugar determinados (que seria, convenientemente, aqui e agora), que é submetido ao envelhecimento irremediável que a nossa relação com o agora impõe e que poderia, enfim, ser lembrado de longe.

Os pontos de ligação (FOUCAULT, 1969/2009) recortam, separam, associam e correlacionam objetos, conceitos e tipos de enunciação, ao mesmo tempo equivalentes e incompatíveis, constituindo unidades capazes de atravessar outros discursos, não sem estarem sujeitas a reprodução, manipulação, transformação, utilização, combinação e decomposição nos diversos outros espaços que podem ocupar.

Nesse discurso, quando o aluno fala ('é falado' pelo discurso), essa posiçãosujeito ocupa um lugar que necessariamente interdita os enunciados contrahegemônicos e herméticos. O dizível na mídia publicitária é o lugar-comum, o óbvio e o difundido. Dizer o mesmo, dizer aquilo que a audiência "quer ouvir" é antes uma condicional para a entrada nesse discurso que um condicionante que se impõe a outros discursos. É antes a submissão da coerência de objetos, conceitos e modalidades enunciativas ao funcionamento de uma instância simbólica que institui o mesmo em nome da memória. A coerência dos "temas" é definida por um princípio de autoria, por espaços de associação, correlação e diferenciação, mas também pelo funcionamento das instâncias simbólicas e funcionais que instituem a mídia como lugar de memória. A mídia publicitária não produz homogeneidades, sem antes alimentar-se delas. Está aí sua potência e sua limitação: ter que dizer de novo pela primeira vez.

O discurso da mídia não requer, não anseia pelo verdadeiro como o discurso científico, por exemplo. Ele nasce no seu seio. Em nossa sociedade, não se pode dizer que o inglês não seja necessário, que a aula não seja interativa, e que a

47 "O enunciado tem em si o poder de ser repetido" (DELEUZE, 1986/2005, p. 23), ou, nas palavras de Foucault, "enquanto uma enunciação pode ser recomeçada ou reevocada, enquanto uma forma (linguística ou lógica) pode ser reatualizada, o enunciado tem a particularidade de poder ser repetido: mas sempre em condições estritas" (1969/2009, p. 118). 
aplicação prática do inglês não seja essencial. Os dispositivos da globalização popularizaram a ideia de que o inglês é imprescindível; a espetacularização das práticas sociais está associada à busca desenfreada e generalizada pelo prazer e pelo entretenimento; e a lógica neoprodutivista nos impõe princípios instrumentalistas e de constante urgência, transformando o inglês em bem simbólico, em commodity, e em ferramenta e técnica. É preciso "ter" o inglês; reconhecer seu valor global; aprender rápido e divertidamente; aplicá-lo na prática, no dia a dia.

Essas instâncias coercivas não demandam relações mais ou menos harmoniosas de conceitos. Ao contrário. Elas traçam uma diagonal entre e através discursos, incorporando "harmoniosamente" contradições e tensões. A sala de aula é centrada nos alunos e tecnológica, e tem o professor como provedor do saber e quadro de giz; as atividades são como video-games e são de completar lacunas; o inglês é praticado em atividades do dia a dia, e não precisa ser o dia a dia do aluno; a aula de hoje é mais interativa que a tradicional, e a reprodução verbal se destaca como prática didática. Usamos "e", e não a conjunção adversativa "mas", para enfatizar que essas oposições convivem em um mesmo espaço associativo, sem risco de incorrer em inconsistência ou contradição, e sem comprometer a unidade coerente do discurso.

Os efeitos da coerência ("temas" e "teorias") do discurso da mídia publicitária devem convidar a audiência alvo a ocupar as posições-sujeito por desejo e processos de identificação. A audiência se reconhece como aluno nas representações e deseja, por exemplo, aprender rapidamente e sem dificuldades. A coerência ou as coerências que se formam no discurso da mídia publicitária devem ser familiares, indiscutíveis e, portanto, criar o que já existe e dizer pela primeira vez aquilo que já é frequentemente repetido e tido como verdadeiro.

\section{Conclusões}

Há algo de particular no discurso da mídia publicitária, além da heterogeneidade discursiva e do interdiscurso. A teia de relações com relação à formação dos objetos, à formação das modalidades enunciativas, e à formação das estratégias é comparável a diversos outros discursos, inclusive os discursos científicos. Já a instância da formação dos conceitos torna o discurso da mídia 
publicitária comparável apenas à institucionalização do senso comum. No interior desses discursos não há definição de domínios de validade, de normatividade e de atualidade, porque eles se apropriam de domínios definidos em outras formações para dispor conceitos em relação com seu objeto, suas modalidades enunciativas e suas estratégias. Mas não se trata de uma mera apropriação ou reprodução do conceito. 0 conceito não é retirado de sua formação, ou seja, não é desconectado da teia de relações de sua produção, tampouco simplesmente é duplicado para ter a réplica tomada pelo discurso da mídia publicitária. Os enunciados não são simplesmente arrastados pelo campo de presença até o espaço da mídia publicitária, mas passam por um devir produzido em um processo de desterritorialização-territorialização. Esses devires também se relacionam com os demais conceitos do campo de presença, constituindo-se, eles próprios, como um conceito ao qual outras formações devem responder. Em outras formações, os enunciados são retomados como alteridades em relação às quais algo se constitui. No discurso da mídia publicitária, eles são tomados e atualizados em relação a eles mesmos, porém em outra rede de relações, que lhe impõem outras condições de sentido.

O discurso da mídia publicitária não fala senão da mercadoria, mas sempre parece falar do conceito, que é aquilo que deve qualificar a mercadoria. Ou seja, diferente do que acontece nos discursos científicos, por exemplo, os enunciados não procurar propriamente constituir ou sustentar um conceito, mas procuram associá-lo à mercadoria. Todo o mecanismo coercivo ou sedutor do discurso da mídia publicitária depende dessa associação. Por isso, no discurso da mídia publicitária, a formação do conceito acontece no plano de fundo, no plano daquilo que deve ser dado, sabido e aceito generalizadamente e o campo de memória é achatado ao ponto de pouco ou nada se distinguir do campo de presença.

Sustentamos que os laços de transformação e de continuidadedescontinuidade histórica não se estabelecem porque os enunciados tratam sempre do agora, mesmo ao falar do passado. Conforme discutimos, em um dos vídeos que compõem nosso corpus, a sala de aula de "antes", mostra um tipo de interação sério, sóbrio e repetitivo, sem constituí-lo como uma memória, mas como um concomitante. É a interação da sala de aula atual de outras escolas, que não a anunciante. 


\title{
Capítulo 5
}

\section{A INFLUENNCIA DO E SOBRE O DISCURSO DA MÍDIA PUBLICITÁRIA COMO TENSÃO CONSTITUTIVA}

\begin{abstract}
Woody Allen made it acceptable for beautiful woman to sleep with nerdy, bespectacled goofballs; all we need to do is fabricate the illusion of intellectual humor, and we somehow have a chance. The irony is that many of the women most susceptible to this scam haven't even seen any of Woody's movies.
\end{abstract}

\section{Charles John "Chuck" Klosterman}

O objetivo deste capítulo é refletir sobre o modo de funcionamento do discurso da mídia publicitária. Analisamos representações de "interação", abordando a pressuposta influência desse discurso (FAIRCLOUGH, 1995/2010; CHARAUDEAU, 2006) e sua concepção como "lugar de memória" (NORA, 1993), e compreendendo que há uma tensão constitutiva no discurso da mídia publicitária pelo jogo de influência do e sobre o discurso da mídia publicitária.

Em uma perspectiva discursiva, é possível argumentar que a mídia publicitária tem lugar privilegiado na constituição da memória discursiva e exerce influência sobre 
o senso comum ${ }^{48}$ ao simplificar e se apropriar de discursos científicos ${ }^{49}$ e veiculá-los com mecanismos tais, de forma que seu discurso se revista de efeitos de verdade e se imponham como tal. Em grande parte, esse argumento pressupõe uma articulação de mecanismos do poder e a ideia de que a mídia constitui um lugar de memória ${ }^{50}$. Analisando peças publicitárias de escolas de inglês focalizando os efeitos de sentido de interação, de fato, encontramos evidência de que o discurso da mídia publicitária tem um modo de organização que estabelece uma relação de influência. Ao mesmo tempo encontramos evidência de que as interpelações, injunções, sugestões e propostas desse discurso funcionam reflexivamente. Essas modalidades alocutivas no discurso publicitário são eficazes na mesma medida em que se constituem como resposta sujeita às interpelações, injunções, sugestões e propostas que se impõem a esse mesmo discurso.

É nesse sentido que abordamos a influência do discurso da mídia publicitária e a questão do investimento simbólico na constituição da mídia como lugar de memória, questionando as ideias de que esse discurso seja uma espécie de "cadeia" de discursos. Argumentamos a partir da análise que os textos publicitários se definem pelo campo problemático criado pela tensão entre os discursos institucionais e os discursos do senso comum e que a influência do discurso da mídia existe apenas na mesma medida em que ele se submete à influência de outros discursos que são tomados como verdadeiros, justamente ao exercer seu lugar de memória.

\footnotetext{
${ }^{48}$ Senso comum compreendido como conjunto de formações discursiva que não têm status de cientificidade e se legitimam como discurso verdadeiro como representação do discurso heterogêneo de uma dada coletividade.

49 Discurso científico aqui tratado como formações discursivas que têm status de discurso verdadeiro legitimado pela cientificidade que se atribui e que é atribuída a ela.

50 Falamos em lugar de memória, conforme Pierre Nora. Para o autor, lugares de memória são lugares simbólicos, materiais e funcionais onde ancoramos nossa memória:

"Mesmo um lugar de aparência puramente material, como um depósito de arquivos, só é lugar de memória se a imaginação o investe de aura simbólica. Mesmo um lugar puramente funcional, como um manual de aula, um testamento, uma associação de antigos combatentes, só entra na categoria se for objeto de um ritual. Mesmo um minuto de silêncio, que parece o extremo de uma significação simbólica, é, ao mesmo tempo, um corte material de uma unidade temporal e serve, periodicamente, a um lembrete concentrado de lembrar. Os três aspectos coexistem sempre (...). É material por seu conteúdo demográfico; funcional por hipótese, pois garante ao mesmo tempo a cristalização da lembrança e sua transmissão; mas simbólica por definição visto que caracteriza por um acontecimento ou uma experiência vivida por pequeno número uma maioria que deles não participou". (NORA, 1993, pp. 21-22)
} 


\section{O discurso da mídia publicitária em análise}

A literatura acadêmica frequentemente aborda o discurso da mídia em função da diversidade dos gêneros textuais veiculados ou de traços que seriam peculiares desse discurso (FAIRCLOUGH, 1995/2010; VAN LEEUWEN, 1993; CHARAUDEAU, 2006; Thompson, 1998), sendo que cada gênero midiático também teria suas peculiaridades.

Ao buscarem generalizações para o que seria distintivo em relação ao discurso da mídia, mesmo admitindo ser uma tarefa difícil, van Leeuwen, Charaudeau, Fairclough e Thompson apontam que:

- O discurso da mídia exerce certa influência sobre sua "audiência".

- Os textos veiculados na mídia são prontos e reproduzíveis.

- No discurso da mídia há uma disjunção temporal e espacial entre as instâncias de produção e de consumo de textos.

Falemos de cada um desses tópicos, apontando brevemente para aspectos problemáticos.

\subsection{Influência do discurso da mídia}

Parece ser um consenso na literatura acadêmica que a mídia exerce influência sobre a sociedade. Charaudeau afirma que "as mídias não transmitem o que ocorre na realidade social, elas impõem o que constroem do espaço público" (CHARAUDEAU, 2006: 19). Ao dizer que as mídias constroem algo do espaço público, o autordefende que não temos acesso direto a realidade, de forma que esta seja necessariamente uma representação da nossa experiência no espaço público:

\footnotetext{
Por trás do discurso midiático, não há um espaço social mascarado, deformado ou parcelado por esse discurso. O espaço social é uma realidade empírica, compósita, não homogênea, que depende, para sua significação, do olhar lançado sobre ele pelos diferentes atores sociais, através dos discursos que produzem para tentar torná-lo inteligível. (CHARAUDEAU, 2006, p. 131)
}

Por outro lado, ao dizer que "elas impõem o que constroem", Charaudeau pressupõe que a representação veiculada pela mídia é necessariamente uma imposição. Usamos a palavra "pressupõe" porque, de fato, o autor não explicita os argumentos que levam à sua conclusão. 
Aparentemente, há um consenso de que a mídia seja nossa principal fonte de informação e, como tal, constitui uma instância dominante da produção de sentidos (CANCLINI, 1997). Com um argumento similar, Fairclough (1995/2010), ao defender a ideia de que o discurso da mídia é uma espécie de cadeia (chains) de eventos comunicativos, implica que o elo anterior da corrente põe o seguinte em movimento ou faz com que ele aconteça. O autor argumenta, citando o exemplo do documentário, que os eventos comunicativos subsequentes bem como as fontes de produção são parte dessa cadeia.

The chain can be extended to include the source communicative events which are transformed into the documentary on the one hand, and subsequent communicative events in which the documentary itself is a transformed source (FAIRCLOUGH, 1995/2010, p. 37).

Em Foucault, a mídia é uma complexa rede de mecanismos de exercício de poder ou "uma materialidade que obedece aos mecanismos da economia e do poder em forma de imprensa, edição, depois de cinema e televisão" (FOUCAULT, 1979/2008, p. 125), de forma que tais mecanismos teriam relação direta com a formação da opinião. Foucault (Idem) afirma que a mídia seria comandada por interesses econômico-políticos e que estariam aí os componentes materiais e econômicos da opinião.

No entanto, tratar da influência do discurso da mídia apenas como uma relação vertical e de sentido único é, no máximo, algo parcial. Já em 1976, o diretor cineasta Sidney Lumet, em "Network" (1976), destaca a influência ou o poder determinante da audiência sobre a linha editorial televisiva. No filme, a premissa mais importante da linha editorial é a de que se a mensagem não entreter, não será ouvida.

Em sua obra, Foucault afirma que o poder não pode ser localizado no Estado, nem em uma instituição, assim como não há pessoas que têm poder e outras que não o têm. Sequer há um objeto chamado poder, uma unidade, essência, entidade ou coisa que possa se definir como poder por características universais (FOUCAULT, 1979/2008). Segundo o autor, o poder é exercício, é prática social constituída historicamente. Em sua leitura da obra de Foucault, Deleuze afirma que "a força nunca existe no singular, pertence à sua essência estar em relação com outras forças, de tal modo que qualquer força é já relação, ou seja, poder” (DELEUZE, 1986/2005, p. 97).

\footnotetext{
${ }^{51}$ No Brasil, traduzido como "Rede de Intrigas".
} 
Essa reflexão sobre o poder poderia nos deixar satisfeitos com a ideia de que a mídia não detém o poder, mas sua agência, por meio de sua complexa rede de mecanismos, tem efeitos tais sobre outras práticas e mobiliza o poder de forma tal que seria possível que ela, a mídia, fizesse valer seus interesses, impondo-os com possibilidades de resistência reduzidas. Essa ideia, por si só, já implica que o discurso da mídia seja heterogêneo, não apenas em relação aos gêneros textuais veiculados, mas também (talvez principalmente) por se constituir nesses e a partir desses mecanismos de exercício de poder.

Por outro lado, se questionarmos a constituição dos mecanismos a serviço da mídia levando a cabo o princípio de que qualquer força seja já relação, podemos argumentar que o jogo de forças que torna tais mecanismos tão poderosos sobre a audiência se alimenta principalmente pelo poder da palavra dessa mesma audiência. O discurso da mídia "deseja" ser senso comum e se constitui em relação a uma projeção abstrata desse senso comum. Isso significa que o discurso da mídia se constitui na e pela sua representação do senso comum e que sua influência existe apenas na mesma medida em que ele se submete à influência de outros discursos que são tomados como verdadeiros no imaginário de sua audiência.

Portanto, há uma relação de mútua influência entre a mídia e sua audiência. Não é possível afirmar, a priori, que a veiculação na mídia exerça maior influência sobre a audiência do que esta exerce na produção e veiculação daquilo que é veiculado.

\subsection{Produção e veiculação de textos}

Também não é incomum o argumento de que os textos veiculados na mídia são prontos e reproduzíveis, de forma que a reprodução seria a recontextualização (recontextualisation) de eventos comunicativos (VAN LEEUWEN, 1993). Segundo Fairclough (2010), o que é veiculado na mídia são produções coletivas e institucionais de textos finais (FAIRCLOUGH, 1995/2010, p. 48). Os eventos comunicativos na mídia seriam como "monólogos", nos quais a audiência não poderia contribuir ou participar diretamente (p. 40).

Nesse sentido, ao afirmar que os textos são finalizados, prontos e fechados, os autores o fazem no sentido de que estariam fechados para a audiência. As 
reproduções dos textos e suas recontextualizações seriam eventos comunicativos subsequentes e que não têm ligação direta com a produção do texto.

Afinal, o que seria exatamente uma participação direta? Qual seria, exatamente, a diferença entre a audiência participar direta ou indiretamente do evento comunicativo? Para Fairclough (2010), o traço distintivo é o feedback simultâneo.

Whereas doctor and patient alternate in speaker and listener roles in a medical consultation, media audiences only listen (or view or read). (FAIRCLOUGH, 1995/2010, p. 40)

Aparentemente, para Fairclough, a alternância de papéis no feedback simultâneo está ligada ao "ouvir" e "falar" em seu sentido mais literal e de materialidade mais marcada. Nas situações de comunicação entre duas pessoas em um diálogo em que há troca de turnos, o feedback simultâneo tem marcas linguísticas mais visíveis e efeitos de responsividade mais sensíveis. Em alguma medida, deveríamos então supor que certos eventos comunicativos têm feedback simultâneo e outros não, desde que levemos em conta que o feedback pode ser verbal ou não, ou ainda, pode ser o silêncio e a "passividade". Ou seja, em uma situação de comunicação, não responder (verbalmente ou de qualquer outra forma) também é feedback. O silêncio funciona como um nó de coerções sobre quem enuncia tanto quanto qualquer outro tipo de feedback.

As mídias digitais têm aberto diversos espaços para diálogo com a audiência e isso é antes exemplar do que exceção. Mesmo no caso das mídias que envolvem transmissão em massa, questionamos o argumento de que o discurso da mídia seja como um monólogo no sentido de falar com as audiências sem que elas possam fazer algo mais que simplesmente ouvir. $O$ argumento de que "as audiências apenas ouvem" ganha coerência apenas se aceitarmos a premissa de que o evento comunicativo midiático é a veiculação do texto. Aceitar tal premissa significa negligenciar que (a) o texto veiculado não pode ser tomado pelo ato de enunciar e que (b) comunicação não é circulação de mensagens, mas sim co-construção de sentidos.

Se tomarmos o texto veiculado como a materialidade de uma unidade de sentido produzida a partir da enunciação, teremos o evento comunicativo como algo que inclui a produção do texto e deixamos de entender que a veiculação seja um evento comunicativo subsequente da produção. Dessa forma, o discurso da mídia não seria seguido do discurso das audiências ou do senso comum, como também não 
simplesmente englobaria essas duas instâncias. O texto veiculado é o atual ${ }^{52}$; é o fruto do campo problemático que constitui o discurso da mídia.

Além disso, passamos a compreender que os produtores do texto midiático não trabalham monologicamente, porque (1) pesquisam o que diz a audiência e (2) ocupam uma posição que dialoga com uma alteridade na posição de audiência.

Dessa posição-audiência, os produtores midiáticos têm constante feedback, seja por meio de pesquisas ou do próprio trabalho coletivo de produção de textos. $A$ cada leitura crítica e produção de uma (nova) versão do texto, o feedback é dado por alguém que fala em nome do sujeito audiência que é presumido. Conforme Sidey Lumet $^{53}$ diria sarcasticamente, para que a audiência ouça, é preciso ouvi-la.

\subsection{Disjunção temporal e espacial}

Este talvez seja o ponto a partir do qual possamos desenhar uma confluência das questões críticas e apontar alternativas. Conforme expomos anteriormente, o discurso da mídia é frequentemente abordado como um fluxo ou uma cadeia de eventos comunicativos. Isso porque um dos principais traços distintivos desse discurso seria certa disjunção temporal e espacial entre a produção e o consumo de um dado texto. Ou seja, seria, na verdade, uma distância espaço-temporal entre os interlocutores na enunciação.

Communicative events differ in their time-space parameters. (...) The fundamental point is that the time and place of production of mass communication text is different from the time and place of consumption, when an audience views or hears or reads it. (FAIRCLOUGH, 1995/2010, p. 36)

O primeiro ponto problemático desse argumento é que ele lida com duas perspectivas sem levar a cabo todas as implicações de cada uma. Se compreendermos "consumo" associado a bens e serviços em sentido material mais estreito, afirmar uma disjunção espaço-temporal seria um pleonasmo. Assim entendido, o consumo seria uma atividade que consiste na apropriação e uso de bens e serviços, o que aconteceria necessariamente após a produção, distribuição e comercialização. Se tomarmos "bens" como coisas que podem também ser "produtos culturais", ou seja, produtos de valor simbólico, a atividade de "consumo" não poderia

52 Conforme Deleuze (1996; 1988/2006; 1995).

${ }^{53}$ Cineasta estadunidense que viveu entre 1924 e 2011. 
mais ser vista como algo que necessariamente segue a produção e circulação. A própria produção do texto midiático poderia ser vista como uma prática de consumo de bens simbólicos. Nesse caso, o argumento de que há uma disjunção espaçotemporal entre as instâncias de produção e consumo não se sustentaria. Tal argumento ganharia força apenas no caso de tomarmos o texto produzido (a materialidade) pelo próprio valor simbólico, ou seja, se tomássemos a marca linguística pelo sentido.

No entanto, a premissa de que os eventos comunicativos diferem em seus parâmetros de tempo e espaço parece ser perfeitamente válida. Quando escrevemos uma carta e a enviamos para alguém, nós nos inscrevemos em um contrato de comunicação assíncrona. Os interlocutores estão separados geograficamente e há um tempo separando a produção da primeira carta, sua leitura e, se for o caso, a produção e leitura de sua carta-resposta.

Argumentamos, no entanto, que é um reducionismo equiparar, mesmo que apenas nesses termos, a comunicação massificada midiática com situações de comunicação assíncrona. A partir dessa perspectiva que nos parece uma simplificação, a produção e a recepção do texto midiático são consideradas diferentes elos em uma cadeia de eventos comunicativos (ou seja, diferentes eventos comunicativos), mas que são considerados eventos de uma prática discursiva comum (FAIRCLOUGH, 2010). Nesse sentido, a questão da recepção dos textos midiáticos é levada em conta, porém de forma limitada. A recepção dos textos é abordada como um aspecto de propriedades gerais de certas práticas discursivas, cujas marcas se materializam no texto.

Proprieties of sociocultural practice shape texts, but by way of shaping the nature of the discourse practice, i.e. the ways in which texts are produced and consumed, which is realized in features of texts. (FAIRCLOUGH, 1995/2010, p. 60)

Essa problemática teórica tem um impacto direto na operação de análise. $A$ análise do discurso da mídia poderia se restringir à análise do texto veiculado, presumindo efeitos de sentido que só poderiam ser verificados com extensa pesquisa etnográfica voltada para a recepção de tal texto.

Além disso, ao tratar do discurso da mídia como uma cadeia de eventos comunicativos, o texto veiculado acaba recebendo, pragmática e teoricamente, o 
status de objeto de estudo desse discurso; sendo que todo e qualquer efeito de sentido associado às audiências seriam objeto de outro estudo.

Talvez esse posicionamento teórico tenha contribuído para o surgimento de abordagens, como a etnografia das audiências (MATTELART \& MATTELART, 1999), a enunciação da recepção publicitária (TRINDADE, 2008) e a análise da recepção (ECOSTEGUY \& JACKS, 2005).

Independentemente de sua produtividade em certo sentido, essas abordagens têm limitações para compreender o discurso da mídia porque têm em comum a mesma premissa problemática: a de que existe, de fato, uma disjunção temporal entre a produção e o consumo de textos quando se trata de veiculação midiática massificada.

Não podemos perder de vista que a enunciação envolve uma relação intersubjetiva de mútua constituição, ou seja, trata-se de uma co-enunciação. $O$ próprio ato de enunciar constitui as posições de enunciador e de enunciatário. (CHARAUDEAU \& MAINGUENEAU, 2004/2008, p. 194). Essa lógica também se aplica ao par locutor-ouvinte, já que "quando fala, o locutor é seu próprio ouvinte e o ouvinte é um locutor virtual" (CHARAUDEAU \& MAINGUENEAU, 2004/2008, p. 155).

Nessa esteira, o "consumo" do texto não é posterior à sua veiculação, mas acontece desde o momento mesmo de construção do texto que se pretende veiculado. Diferentemente de um bem material, o bem simbólico (e mesmo as representações do ou a partir do bem material) não pode ser consumido apenas "depois" de produzido, porque isso implicaria admitir que:

- As práticas sociais não necessariamente reclamam sentido;

- O sentido é um salto da não existência para a existência; e que

- O sentido pode atingir o status de "pronto", finalizado.

Um determinado texto veiculado na mídia não encerra em si os sentidos nem constitui o próprio bem simbólico, se não sua materialidade; o sentido não é dado, é sempre adiado, conforme Derrida (2000/2008, p. 60):

A tal "própria coisa" é desde sempre um representamen subtraído à simplicidade da evidência intuitiva. O representamen funciona somente suscitando um interpretante que torna-se ele mesmo signo e assim ao infinito. A identidade a si do significado se esquiva e se desloca incessantemente. $O$ próprio do representamen é ser si e um outro, de se produzir como uma estrutura de remessa, de se distrair de si. O próprio do representamen é não ser próprio, isto é, absolutamente próximo de si. 
Além disso, não podemos admitir que o texto veiculado na mídia seja feito de materialidades que, quando recepcionado, fará sentido e será consumido pela audiência. O que está em jogo não são ouvintes ou indivíduos, mas sim os efeitos de suas posições para a constituição da enunciação e do enunciado. $\mathrm{Na}$ nossa perspectiva discursiva, a realidade se constitui na linguagem, no sentido de que nossa relação com o mundo é mediada por signos e representações.

\subsection{Tensão constitutiva}

Conforme discutimos, parece ser relativamente comum a ideia de que há uma espécie de fluxo de produção de sentidos, o qual teria a mídia como ponto de partida e o "público" como alvo, de forma que os efeitos de sentido midiatizados afetassem e influenciassem as práticas e os discursos. Dito de outra forma e sob o risco de simplificação, seria como se a mídia tivesse um papel de influência presumida sobre sua audiência, a qual deveria ser analisada, confirmada, verificada.

Essa visão parece ser compartilhada por pesquisadores (CANCLINI, 1995; ECOSTEGUY \& JACKS, 2005; Barbosa \& Trindade, 2003) que focalizam teorias de recepção de textos midiáticos. Com tal foco, pretendem abarcar o que consideram ser especificidades da enunciação publicitária, entendida como:

[...] atividade da comunicação cultural, de natureza 'linguageira' (manifestase no cotidiano), hibridizada [...] exercida por aqueles que possuem competências para constituí-la nos diferentes níveis da emissão [...] mas também por aqueles sujeitos da enunciação nos diferentes níveis do processo de recepção, nos momentos/espaços que esses sujeitos da enunciação na recepção interagem com os enunciados, que os estimulam à aceitação de valores e que, por seu intermédio levam às mercadorias/bens materiais e simbólicos. (BARBOSA \& TRINDADE, 2003, p. 10)

Nessa perspectiva, perpetua-se a compreensão da dinâmica de produção e circulação de sentidos midiatizados que negligencia um elemento importante de sua complexidade e deixa de problematizar o que é entendido como fluxo da produção e da recepção publicitária. O fluxo da produção, no nosso caso, seria constituído pelos anúncios e comerciais sobre a educação veiculados nos vários suportes midiáticos que permeiam o cotidiano dos indivíduos, mas principalmente os suportes impressos e os em mídia digital. Tais mensagens resultariam de um processo que envolve anunciantes, agências e meios de comunicação, constituindo um evento de produção discursiva. Já o fluxo da recepção seria "a observação de como estas mensagens são 
incorporadas pelos indivíduos em seus contextos de recepção" (PIEDRAS, 2006, p. 68). Ou seja, poderíamos nos perguntar de que forma a audiência desses anúncios consome os valores simbólicos veiculados, incorporando-os em seu contexto de recepção e atuação.

Por tudo o que argumentamos até aqui, nossa perspectiva questiona, disputa, problematiza a existência desses dois fluxos e compreende que não se trata exatamente de uma influência do discurso midiático sobre outro discurso ou outras práticas sociais. Trata-se de complexas práticas de valores simbólicos (portanto, ideológicos) que constituem discursos que não têm uma relação de determinação, mas de coerção e mútua influência.

No plano das unidades materiais do discurso midiático, não questionamos o argumento segundo o qual os textos da mídia operam como "commodities" culturais:

[Media texts] are part of the business of entertaining people, are designed to keep people politically and socially informed, are cultural artefacts in their own right, informed by particular aesthetics (FAIRCLOUGH, 1995/2010, pp. 4748).

Também não questionamos, conforme defende Fairclough, que os textos da mídia tenham um papel ideológico no controle e na reprodução de práticas sociais (1995). Ao mesmo tempo, argumentamos que as práticas sociais têm papel ideológico no controle e na (re)produção de textos da mídia. Quais textos podem ou não circular nos veículos de comunicação? Quais discursos podem ser ditos e quais estão interditados? Quais são as forças que interditam? Pensar o discurso da mídia publicitária como um fluxo o posicionaria como uma espécie de articulador do poder, mas essas perguntas apontam que o discurso da mídia publicitária está ele próprio sujeito a uma rede de relações de poder.

Além disso, na tentativa de recortar um discurso midiático, devemos ter em mente que não se trata meramente de separar textos de determinados veículos de comunicação. Em uma percepção superficial, um texto veiculado na televisão é "claramente" midiático. Um texto veiculado em um site de notícias, também. Mas as "claras" distinções logo se recobrem de incertezas quando nos perguntamos, por exemplo, se um texto publicado em um site de rede social pode ser considerado midiático. Que condições poderiam contribuir para que tal texto pudesse ou não ser considerado midiático? Diante dessa pergunta, poder-se-ia afirmar que "depende de quem fala”. É precisamente nesse ponto que não podemos nos deixar levar por uma 
relação superficial entre texto, "meio" (medium) e aquele que fala para definir referências de recorte sobre o que é texto midiático.

Poderíamos então considerar que o texto midiático é aquele produzido ou veiculado por instituições que detêm direito, poder ou concessão para atuar na área de comunicação de massa. Mas essa consideração também é frágil. Os chamados youtubers ${ }^{54}$ põem em cheque a associação direta do texto midiático com esses tipos de instituições. Os textos de youtubers também operam como commodities culturais e têm efeitos como aqueles que atribuímos ao discurso da mídia. Poderíamos nos questionar se os youtubers não poderiam, assim, ser considerados instituições em seu próprio direito. Nesse caso, poderíamos também nos perguntar sobre o que é que legitima um youtuber, ou ainda, deveríamos nos questionar sobre como o youtuber é institucionalizado.

Os textos midiáticos e, em última instância, o discurso midiático não se definem pelo meio de comunicação nem pela posição de sujeito de quem fala. Eles se definem pelo campo problemático criado pela tensão entre os discursos institucionais e os discursos do senso comum.

Qual seria ou quais seriam os traços distintivos do discurso da mídia? Este tem a particularidade de ser um discurso "entre" (in between) discursos, adiado, latente e constituído por um complexo de coerções para (re)produção de discursos.

Quando vemos um comercial de uma dada escola de idiomas, por exemplo, trata-se de um discurso institucional no sentido de que os efeitos de sentido se constroem em nome da instituição (de seu ethos) e é ela que assume (implícita ou explicitamente) a posição daquele que fala. Quando atestamos a alta frequência de certos dizeres no "dia a dia" e os reconhecemos em veiculações da mídia, independentemente de nossa pressa em atribuir uma relação unilateral de influência da "mídia", o fato é que podemos estar diante de dizeres do senso comum, ou seja, podemos estar diante do discurso em que se constitui uma posição de sujeito que poderia ser representada por significantes como "as pessoas" ou "as massas". Quando vemos um dado canal de televisão se posicionar publicamente via comunicação massificada, estamos diante do discurso institucional da organização que responde pelo canal de televisão. As instituições dos diferentes canais podem se

54 São personalidades no site Youtube que têm grandes audiências em seus canais e cujos vídeos circulam amplamente na internet. 
posicionar de formas diversas, assim como as instituições que anunciam nos canais, da mesma forma que o senso comum não constitui um discurso uniforme, sem descontinuidades e contradições.

O discurso do professor; o discurso médico; o discurso científico; o discurso do senso comum; o discurso legal ou qualquer outro discurso nomeado dessa forma implica grande parte de recorrências em torno de certa posição de enunciação ou de sujeito do discurso: "o professor", "o médico", "o cientista”, “o povo”, "o jurista”. No caso do discurso da mídia, qual seria a posição de enunciação ou qual seria o sujeito do discurso? Quem é, afinal, aquele que fala?

O discurso da mídia se constitui como um campo problemático ${ }^{55}$, no qual a ordem do discurso opera e as regras de formação mantêm seus efeitos, mas também no qual a interdiscursividade parece ser elevada à potência. Há uma ordem que limita e recorta esse discurso, como qualquer outro, conjurando suas dimensões de acontecimento, de acaso, de desejo e de poder. No entanto, quando nos perguntamos sobre "aquele que fala" no caso do discurso da mídia, por exemplo, somos levados a uma posição de sujeito que se constitui em um discurso institucional e, ao mesmo tempo, em uma posição-sujeito problemática que fala em nome da mídia e em nome de quem a mídia fala. Se quisermos como referência a esfera da enunciação, o enunciador que apreendemos em um texto na mídia é uma instituição (inclusive o senso comum institucionalizado) e, ao mesmo tempo, um eu virtualizado pelo problema do encontro de discursos que constitui o discurso midiático.

Nesse sentido, diferente dos outros discursos, para apreender "quem pronuncia" o discurso da mídia, não somos remetidos à apreensão de uma posição de sujeito, mas sim a de um campo problemático de coerções para as posições-sujeito nesse discurso. Assim, as regularidades do discurso da mídia não se resumem às regularidades que podem ser apreendidas na análise de textos veiculados na mídia e tampouco podem simplesmente ser somadas às regularidades do discurso das audiências ou do senso comum. As regularidades do discurso da mídia estão sujeitas à tensão desses entre-discursos.

No caso do discurso da mídia, não é possível falar de uma posição-sujeito que seria "a mídia" tampouco de regras de formação que possam delimitar enunciados por

\footnotetext{
55 Usamos o termo "problemático" conforme Deleuze (2000), fazendo referência ao modo como os
} acontecimentos se dão por meio dos encontros. 
suas regularidades entre os objetos, os tipos de enunciação, os conceitos e as escolhas temáticas (FOUCAULT, 1969/2009) da mesma forma que acontece com outras formações discursivas. De fato, as regras de formação do discurso da mídia são elevadas à potência e constituem um jogo de forças que agem como um nó de coerções para constituição de posições-sujeito e formações discursivas. A mídia não diz, não pronuncia; mas torna possível que alguém diga; que alguém pronuncie, limitando e recortando seu discurso. Voltaremos a essa questão ao refletirmos sobre as regras de dispersão do discurso da mídia publicitária.

O discurso da mídia tem um papel decisivo na constituição de memórias na nossa sociedade (CARMAGNANI, 2014; GRIGOLETTO, 2011; NORA, 1993) e também aí entrevemos esse campo problemático. Conforme Grigoletto (Idem) afirma a partir das contribuições de Nora (Idem), a mídia se constitui como um lugar de memória. Para o autor (NORA, 1993), lugares de memória são lugares simbólicos, materiais e funcionais onde ancoramos nossa memória e, para a autora (GRIGOLETTO, 2011, p. 304), a mídia "parece atender aos três requisitos". Dos três requisitos, o investimento simbólico é justamente aquele que deixa entrever o campo problemático. Se "o discurso midiático se apropria de diversos meios para homogeneizar sentidos, estabelecer verdade(s), manter e/ou criar um consenso necessário para atestar a sintonia de interesses e a união de pessoas ou instituições em torno de uma comunidade" (CARMAGNANI, 2014), mas essa condição também é atribuída justamente pelo investimento simbólico que ela recebe dessa mesma comunidade. A mídia influencia, cria, estabelece e sedimenta na mesma medida em que se submete aos investimentos e ao jogo de coerções que constroem o seu lugar.

\section{Análise de textos publicitários}

Nesta parte, primeiramente fazemos a análise de peças publicitárias, uma a uma, e então explicitamos recorrências. Na análise, buscamos apreender a constituição dos sujeitos no discurso: as posições que eles ocupam; as relações de poder estabelecidas; e representações de interação e interatividade.

O primeiro vídeo publicitário em análise (vídeo A) é parte de uma campanha que tem outros dois vídeos e, nos três casos, as mensagens inicial e final são, respectivamente: 
"Se você gosta de [tema da peça publicitária], você aprende inglês."

"Parabéns, você acabou de aprender três palavras novas, se divertindo. No [nome da marca] é assim: você gosta, você aprende."

\section{Figura 9: Vídeo A - Screenshot $1^{56}$}

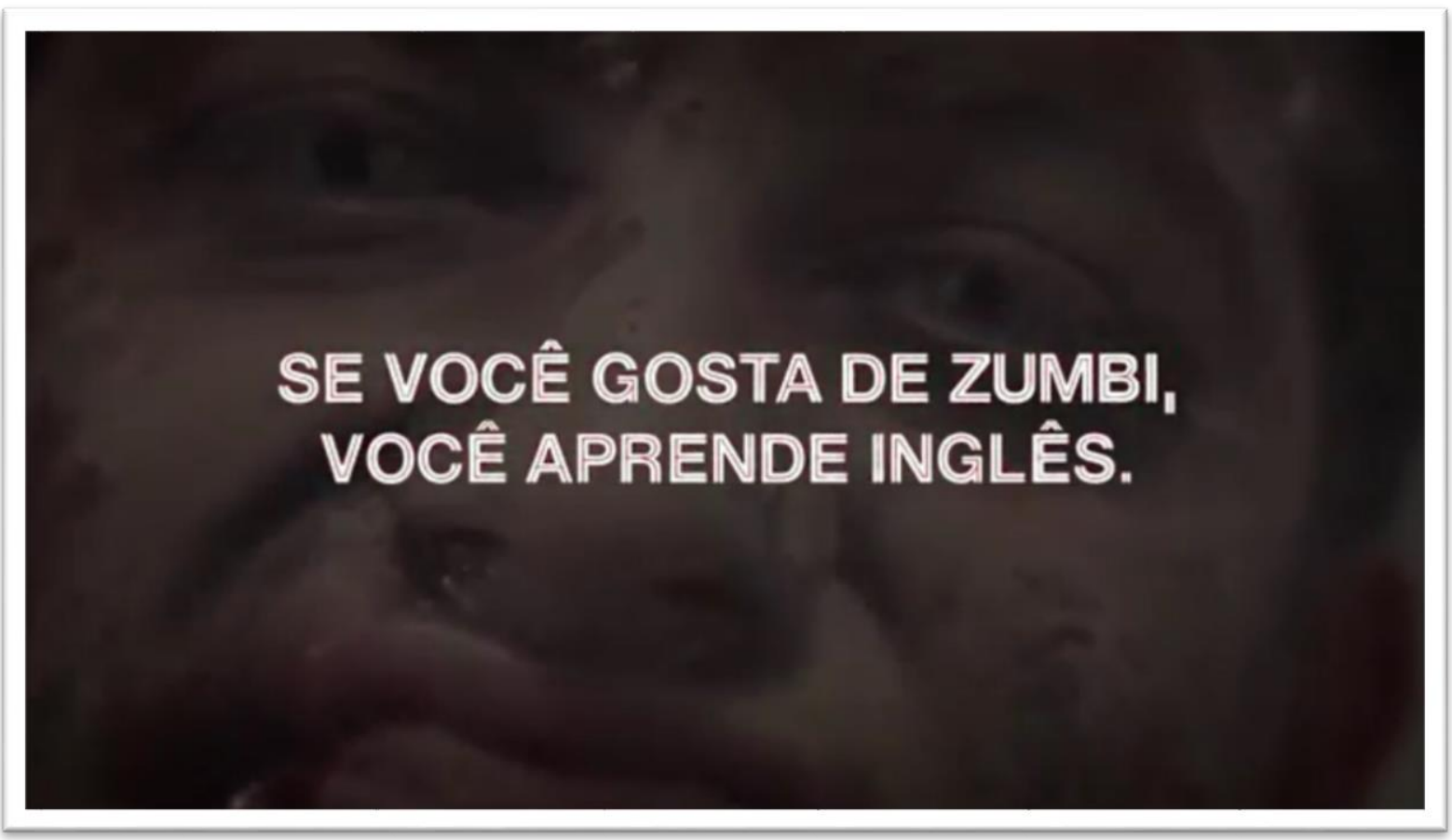

Entre a abertura e o fechamento, o mesmo desenvolvimento: uma sequência de três perguntas com uma lacuna a ser preenchida, sendo que a audiência clica em uma entre três opções dadas para completar a lacuna e, assim, dar continuidade no vídeo.

No vídeo em análise, a construção enunciativa constitui sujeitos na posição de professor e de aluno. O professor interpela (ao se dirigir ao outro como "você"), estabelece ações a realizar e impõe essas ações ao aluno (atribui atividades de completar lacunas). O professor atribui a si certo estatuto de poder; uma posição de ascensão sobre o aluno. Constrói-se uma representação da relação professor-aluno que é fundamentalmente vertical.

Em "se você gosta de zumbi, você aprende inglês", "você" tem um duplo efeito: você genérico, para o argumento de como se aprende inglês; e você que interpela o sujeito-aluno.

${ }^{56}$ Anexo 1. 
Figura 10: Vídeo A - Screenshot 2

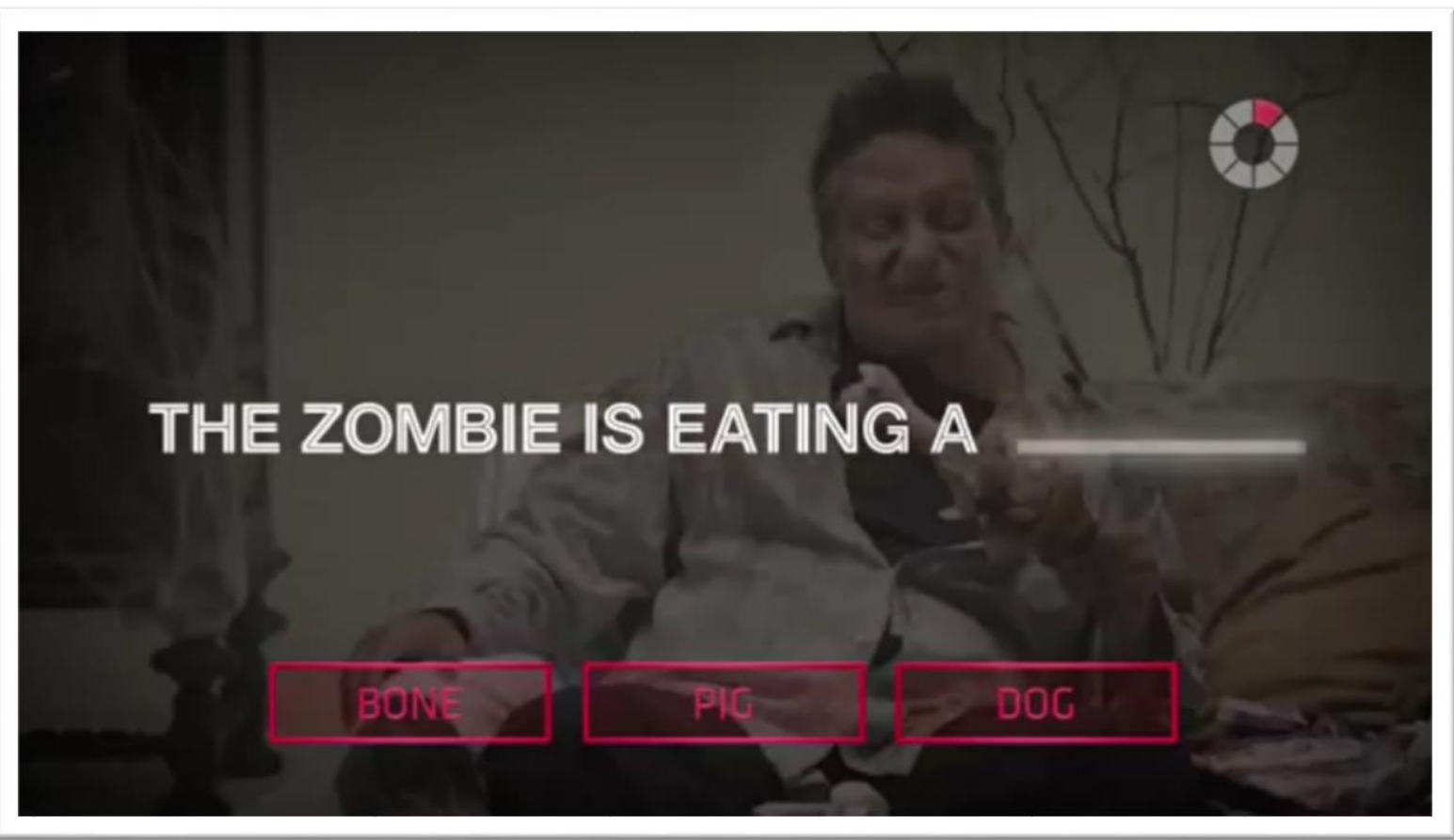

Com o primeiro efeito, o enunciador também atribui a si um estatuto de saber. Com o enunciado "se você gosta de zumbi, você aprende inglês", o enunciador estabelece uma relação de poder-saber na qual ele sabe e o outro não: ele sabe inglês, o outro não; ele sabe como se aprende inglês, o outro não.

Figura 11: Vídeo A - Screenshot 3

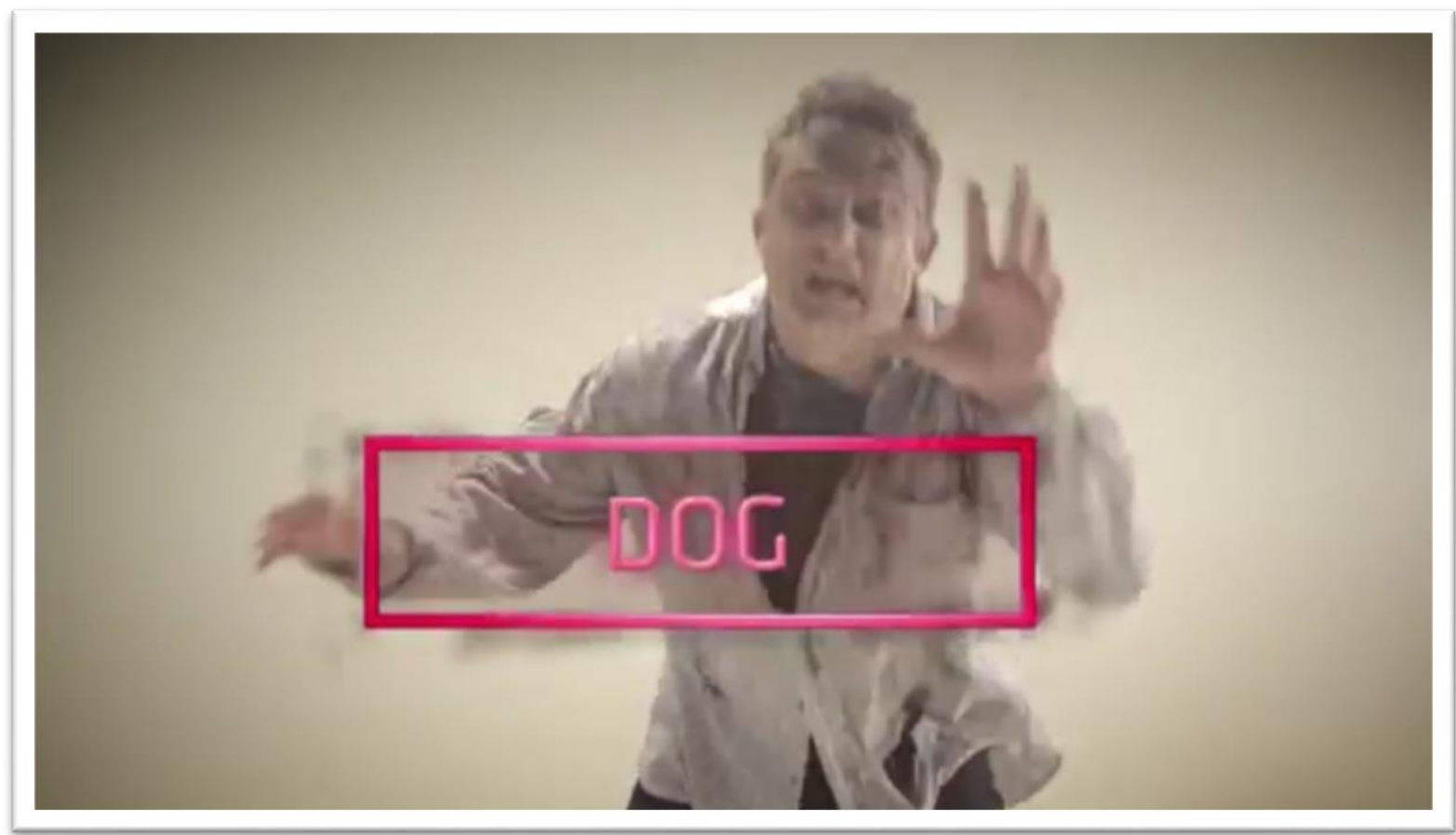


Com o segundo efeito, quase que obrigado a significar sua presença no sentido de se perceber como alvo de identificação, o sujeito-aluno se constitui na posição de quem reage e responde. A entonação enfática de "aprende" em "você aprende inglês" reforça essa posição e, ao mesmo tempo, atribui ao sujeito-aluno a competência para executar as atividades que seguirão e, em última instância, atribui a competência para aprender inglês.

No vídeo $A$, os sujeitos são inscritos em uma formação ideológica que pressupõe a sala de aula de lógica hierárquica vertical, atribuindo ao professor à posição central, aquela que detém o conhecimento e que exerce autoridade. Ideologia que, por implicação, pressupõe a possibilidade de posse de conhecimento; de conhecimento localizado e centralizado.

A presença de "gosta" em "se você gosta de zumbi, você aprende inglês" e em "você gosta, você aprende" remete a pelo menos duas regiões do interdiscurso: aos discursos sobre o interesse do aluno em aprender; e àqueles sobre os fatores afetivos da aprendizagem.

\section{Figura 12: Vídeo A - Screenshot 4}

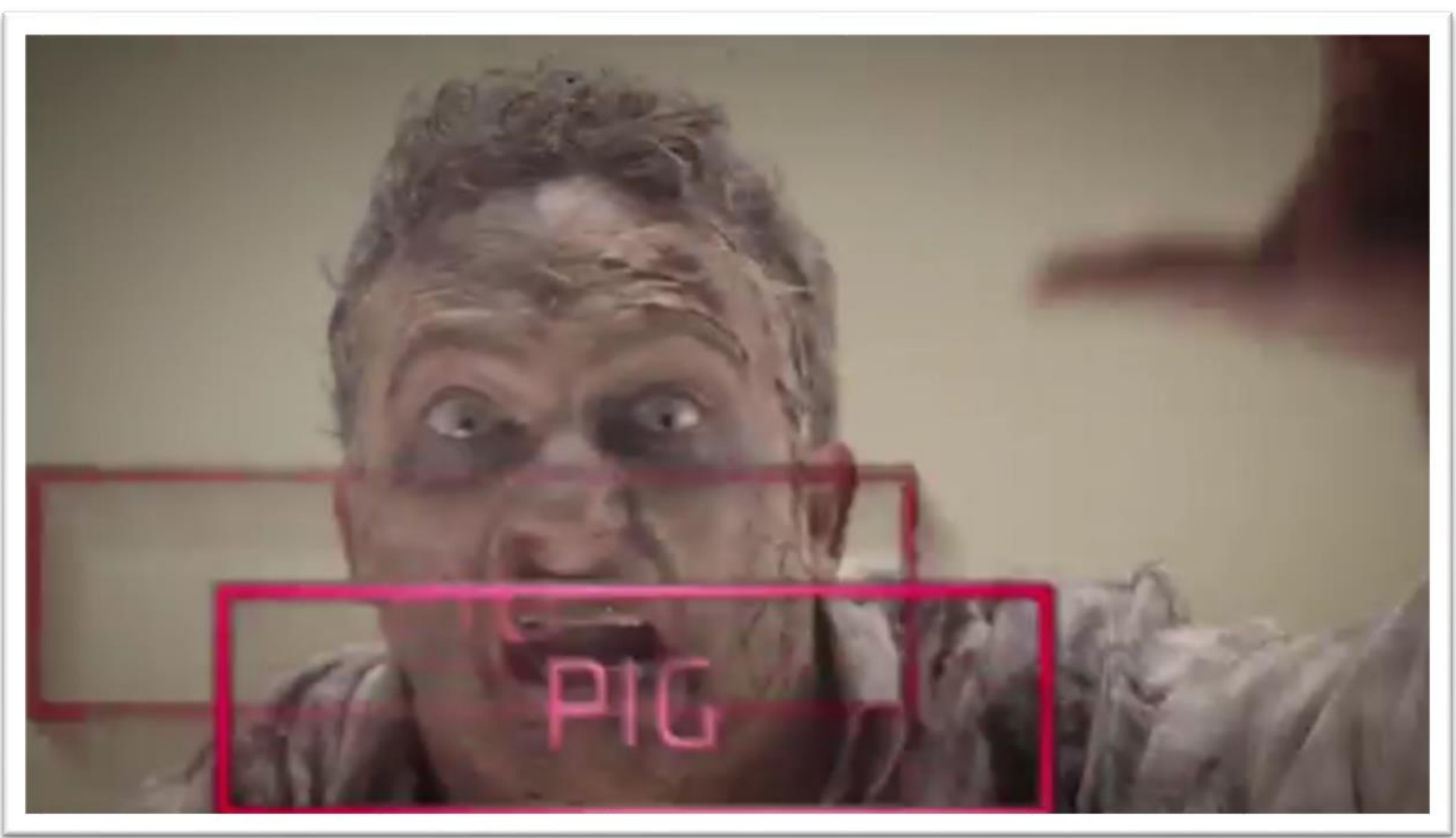

Por um lado, nos discursos filiados a ideologia do conhecimento localizado e transmitido e a paradigmas educacionais produtivistas, a responsabilidade de ensinar é do professor e a de aprender, do aluno. À parte de fatores relacionados com 
deficiência, déficit de inteligência ou qualquer outro tipo de inaptidão, nessa região do interdiscurso, pressupõe-se que o aluno deva ter pleno interesse pela aula e pelo conteúdo, não apenas como forma de viabilizar o aprendizado, mas também porque é sua obrigação.

Por outro lado, nos discursos filiados a ideologia da espetacularização da vida cultural e da vida social, e a paradigmas educacionais neoprodutivistas, os fatores afetivos são indispensáveis à aprendizagem e cabe ao professor motivar e entreter o aluno como forma de favorecer tais fatores. Em "no [nome da marca] é assim: você gosta, você aprende", o enunciador garante que a sala de aula nessa instituição fará o aluno gostar e, consequentemente, aprender. Algo como "nessa instituição, você gosta", onde "gosta" tem o efeito de "se diverte" já que se articula com "você acabou de aprender três palavras novas, se divertindo".

\section{Figura 13: Vídeo A - Screenshot 5}

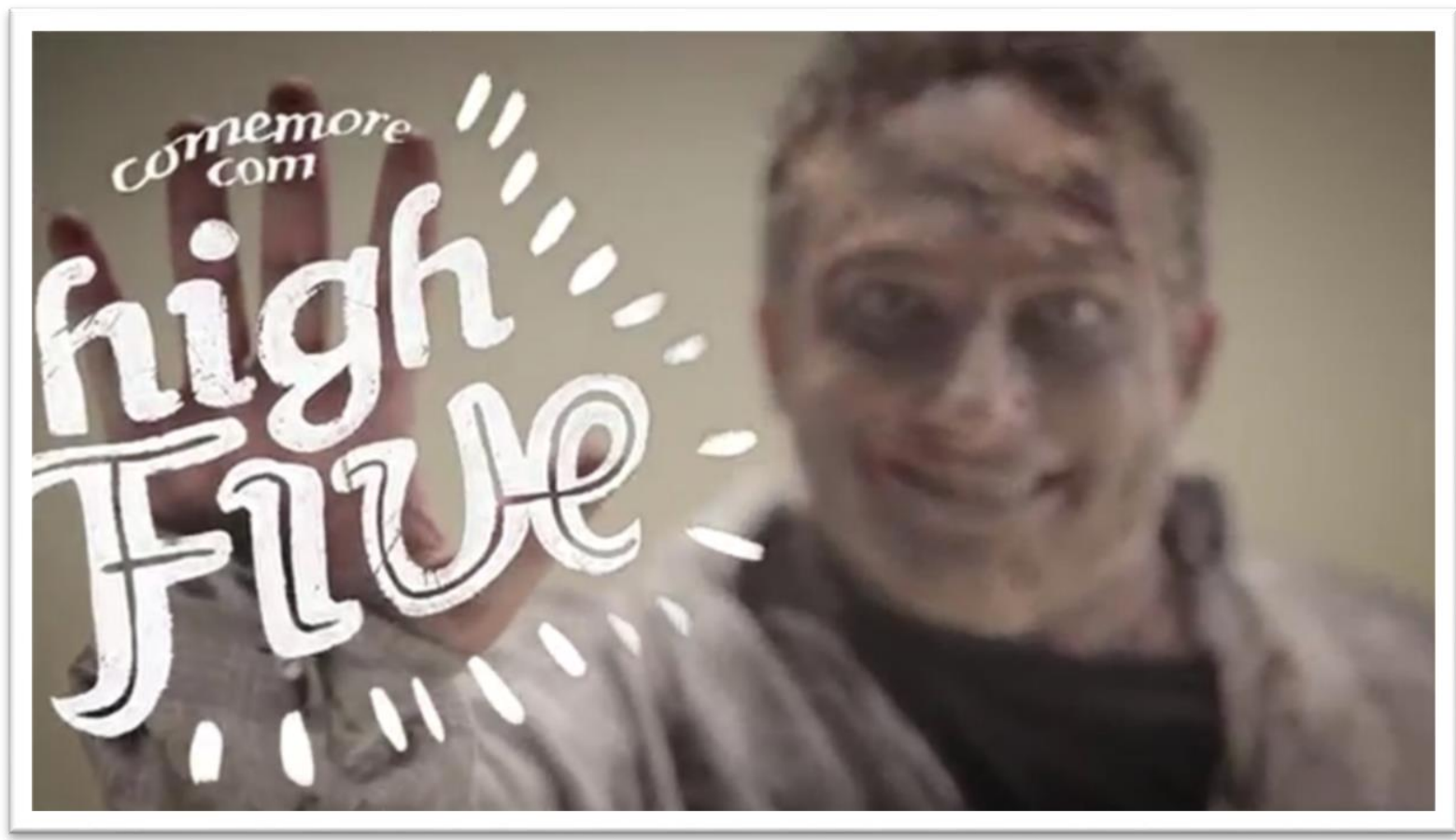

Nesse sentido, na materialidade do texto, a partir da organização do discurso em torno das modalidades alocutivas que interpelam a audiência como (possível) aluno e que pretendem convencer essa audiência a um fazer, não há evidência de que haja influência no sentido de o sujeito-professor tentar convencer de que a diversão é definitivamente o meio através do qual o aprendizado é assegurado. O que ocorre é que, partindo do pressuposto de que a diversão é definitivamente o meio 
através do qual o aprendizado é assegurado, o sujeito-professor tenta convencer a audiência de que em sua instituição o aluno certamente se diverte. Ou seja, nesse caso, o discurso da mídia publicitária não está propriamente construindo, instituindo ou impondo uma representação sobre o modo como se aprende inglês a se inscrever ou se sedimentar como memória. Nesse caso, a mídia apresenta um texto sedutor que "reestabelece" um pré-construído sobre como se aprende inglês, atualizando-o e reiterando-o.

\section{Figura 14: Vídeo A - Screenshot 6}

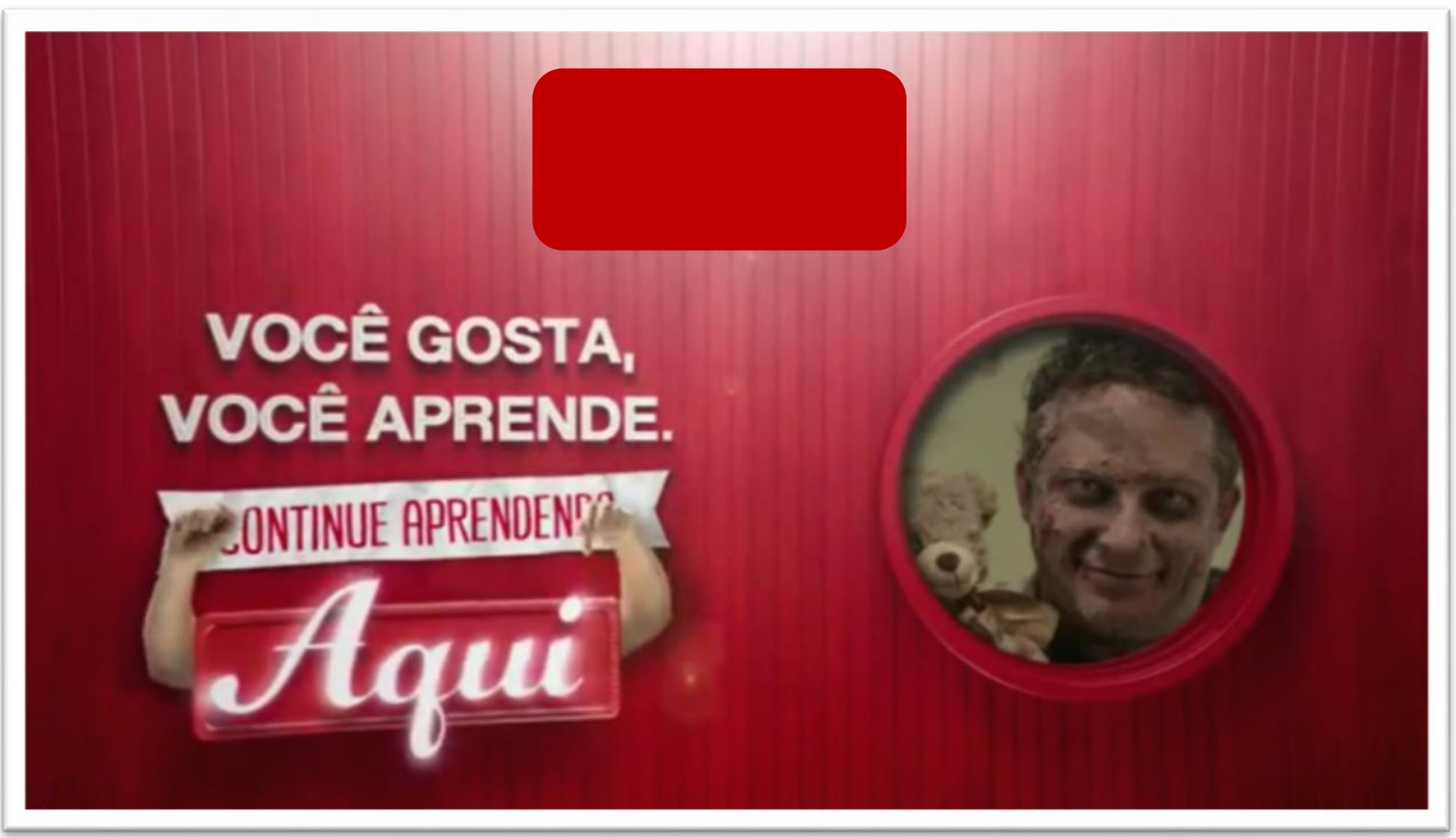

Após a proposição sobre como se aprende inglês (nessa instituição), o sujeitoprofessor estabelece ações a realizar e impõe essas ações ao outro ao atribuir atividades de completar lacunas. Nessa relação professor-aluno, é possível sustentar que as atividades têm principalmente duas funções: provar a proposição sobre como se aprende inglês; e convidar o aluno a interagir. No entanto, argumentamos que a primeira função não é provar que se aprende inglês ao se divertir, mas sim provar que nessa instituição o aluno se diverte para aprender. 
As atividades correspondem às seguintes perguntas:

\begin{tabular}{|l|l|}
\hline THE ZOMBIE IS EATING A _ & BONE, PIG, DOG \\
\hline THE ZOMBIE IS HOLDING A & TEDDY BEAR, BALL, JOYSTICK \\
\hline THE ZOMBIE IS FEELING & SCARED, HAPPY, SAD \\
\hline
\end{tabular}

Cada uma das perguntas tem três alternativas, entre as quais uma é correta. O conjunto das perguntas constitui uma atividade que pretende levar o sujeito-aluno a uma experiência positiva com palavras em inglês. O modo como a atividade é apresentada configura um fluxo fechado de ações.

O sujeito-professor faz perguntas e cabe ao sujeito-aluno responder corretamente. A resposta certa é celebrada com um cumprimento jovial e informal no estilo high five. A resposta errada é sancionada e acarreta a repetição da pergunta, até que a resposta seja correta. O erro não tem outro feedback que não a sansão, mas o fato dele acarretar a repetição da pergunta e de haver apenas duas alternativas erradas deixa poucas chances para o aluno, por fim, não acertar. Ao acertar, o aluno preenche a lacuna e infere o sentido da palavra associada ao objeto mostrado no vídeo.

Esse é o traço que permite o argumento de que o sujeito-professor prova a proposição sobre como se aprende inglês e parabeniza o sujeito-aluno por ter conseguido "aprender três palavras novas, se divertindo". A peça publicitária implica sua audiência em um fluxo linear de ações que funciona como simulação ou amostra do tipo de experiência que a audiência terá após sua matrícula na instituição, provando que, se é verdade que aprendemos nos divertindo, nessa instituição a audiência certamente vai aprender.

Figura 15: Fluxo de Ações

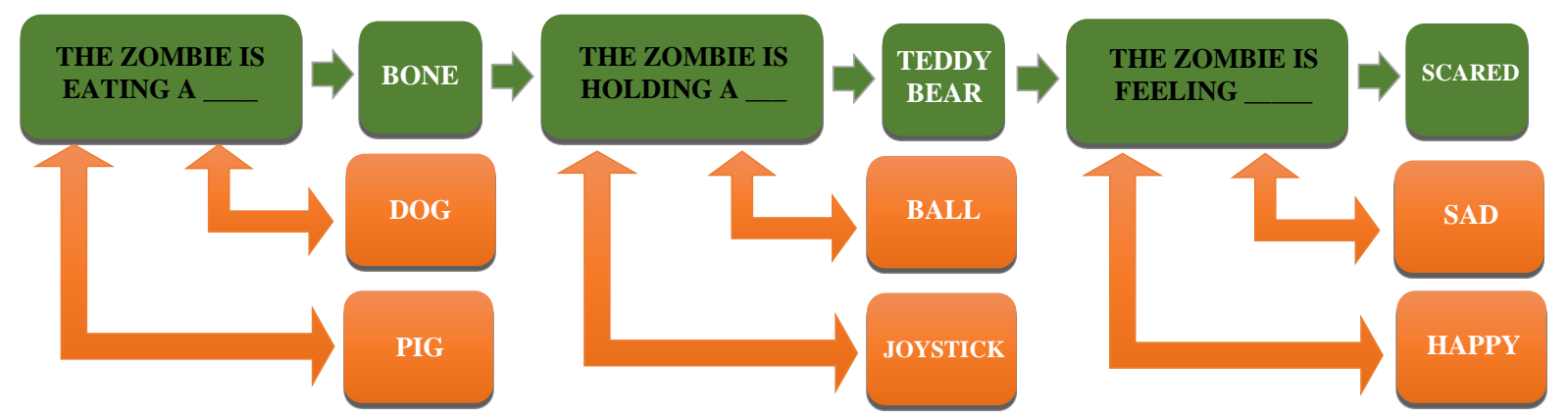


A construção do fluxo de ações se concentra em garantir que a audiência conheça as três palavras em inglês, pressupondo que gostem de zumbis e que prefiram se divertir a estudar. Nesse fluxo, a ação que é esperada do sujeito-aluno se aproxima do caráter de atividades de completar lacunas, que são mais frequentemente associadas a teorias de aprendizagem comportamentalistas. Ou seja, trata-se de um fluxo linear, reproduzível e reprodutivista de interação. Um acontecimento sucede o outro em uma ordem pré-determinada e com efeitos previsíveis.

Quando dizemos pré-determinada, não significa conceber que a única alternativa não linear seria uma sequência de fato aberta, a qual seria resultado de uma programação que previsse criação de possibilidades a depender das ações e das escolhas de quem interage. Na verdade, nós nos referimos aqui aos efeitos da interação e não diretamente às suas determinações de programação. É possível que determinada programação linear possibilite que a interação não tenha efeitos de uma ordem pré-determinada de eventos ou ações. Cada vez que o sujeito-aluno "erra" a alternativa que completa a frase, ele recebe a mesma mensagem de sanção e o vídeo é retomado do mesmo ponto da pergunta para que ele tente novamente. Esse efeito de ida e volta linear poderia não existir. Como são apenas três alternativas, é razoável pressupor que o sujeito-aluno poderia errar até duas vezes cada uma das três perguntas, totalizando seis erros e três acertos possíveis. Se fossem criadas seis sanções diferentes e específicas para cada tipo de erro e três celebrações diferentes, também especificadas em função daquilo que foi acertado, o efeito seria de um enunciador que de fato responde ao que acontece na tela e não o de um fluxo mecanizado de ações e reações. Ou seja, mesmo se tratando de um sistema fechado de opções, essa alternativa criaria efeitos de interação mais complexos.

Essa articulação até certo ponto contraditória entre as marcas verbais e o fluxo de ações que constituem esse texto publicitário, por um lado, "restabelece", atualiza e reitera o pré-construído da associação direta entre entretenimento, interação e aprendizagem na sala de aula de inglês, principalmente em escolas livres. Esse préconstruído se sedimenta embebido na cultura do espetáculo e entretenimento (DEBORD, 1997/2013). O enunciado "você gosta, você aprende" é a materialidade marcada do discurso do entretenimento. Não se trata de aprender e interagir; nem de aprender, mas interagir. Trata-se de aprender ao interagir, sendo que "interagir" fica 
diretamente associada à ideia de entretenimento. Sem o devido cuidado, e isso frequentemente ocorre, esses efeitos de sentido poderiam ser aproximados do discurso científico construtivista e socioconstrutivista. No entanto, conforme dissemos, a ideia de interação aqui se articula com o "gostar", com o sentimento de achar "legal", "bacana", "maneiro". Não é qualquer atividade que se configura como uma interação. Para isso, é preciso que a atividade seja prazerosa; é preciso gostar do que se está fazendo. Nesse contexto, fazer com prazer ("gostar") é aprender.

\section{Figura 16: Vídeo B - Screenshot $1{ }^{57}$}

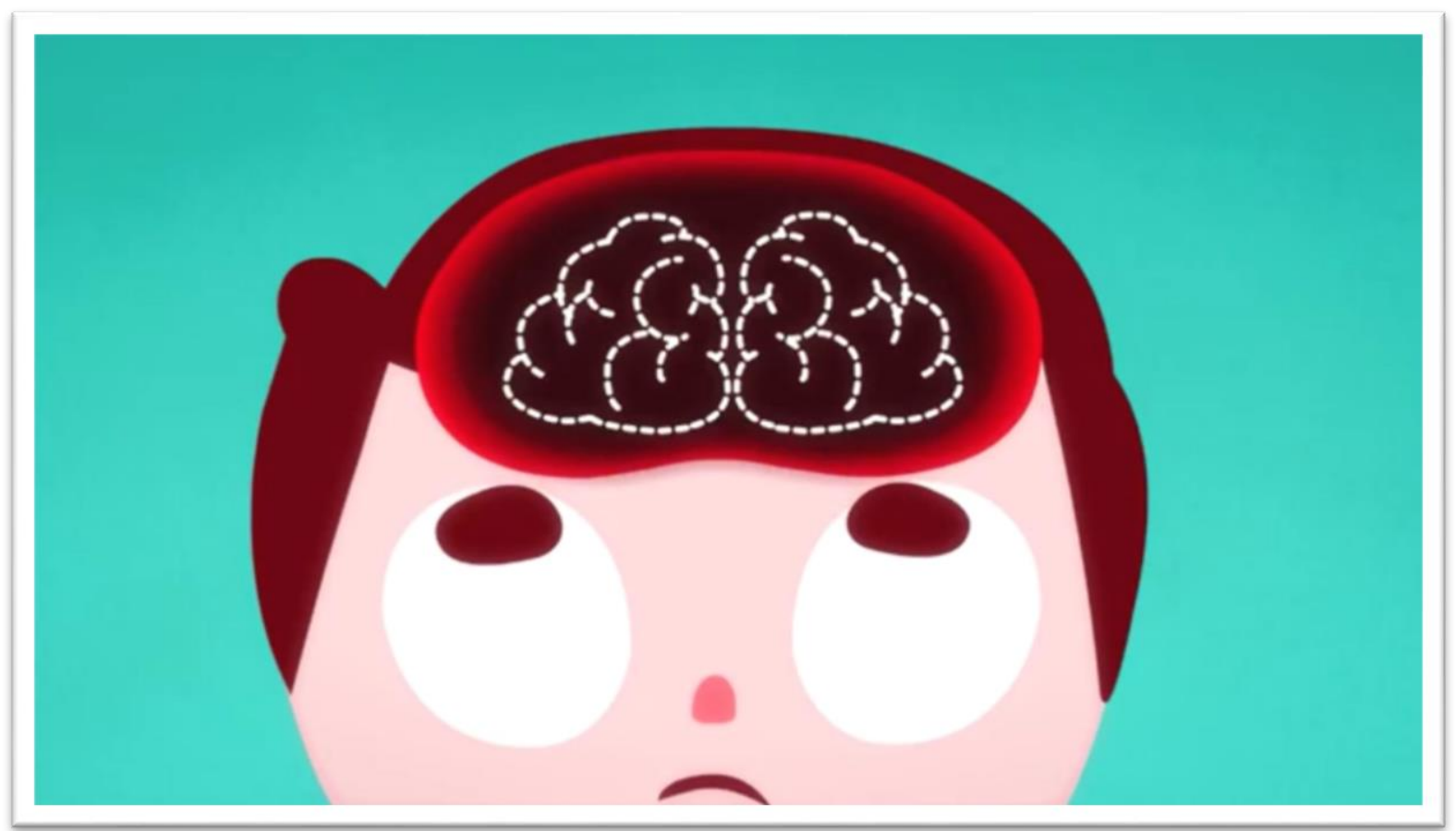

Por outro lado, o fluxo de ações da audiência também deixa entrever a coexistência conflituosa de um modelo de interação que é associado à ideia de marasmo, chatice, seriedade e apatia, e que também é tido como atividade prazerosa. O modelo de atividades de completar lacunas com suas raízes comportamentalistas e práticas lineares, reproduzíveis e reprodutivistas, tão marcado como interação chata e apática é justamente o modelo revisto como interação divertida e prazerosa. Esse discurso publicitário não apresenta evidência de proposta de novo ou novos modelos de interação, que seriam mais atraentes e divertidos. Ele retoma um modelo de interação já estabelecido, pressupondo uma ideia de aprendizagem como atividade divertida e tentando convencer a audiência que nessa instituição se aprende inglês.

${ }^{57}$ Anexo 2. 
O convite bem-sucedido para o aluno interagir tem como resultado o "aprendizado" de 3 palavras em inglês.

Em outra campanha publicitária, de outra marca da mesma área, há diferenças e semelhanças significativas. As diferenças estão nas posições de sujeito no discurso e no tipo de relação entre os co-enunciadores e seus papéis em relação ao texto. As semelhanças estão na representação do professor, do aluno e da interação.

O vídeo é produzido de forma que o aproxima do gênero documentário. Ele traz recortes da sala de aula e daqueles que a habitam: professor e aluno. Ao fundo, sem ser nomeado ou identificado, um narrador-especialista. A sequência do vídeo gira em torno da explicação do especialista sobre como se aprende inglês em "outros lugares" e na instituição que o especialista representa. À parte da abertura e até pouco antes do último quinto de duração do vídeo, o especialista não revela explicitamente sua filiação à instituição. Quando finalmente afirma "nosso método..." e aconselha sua audiência com "venha...", é possível ver mais explicitamente sua posição de especialista em nome da instituição, mas sua argumentação já está consolidada ao ponto dessa revelação não poder mais abalar sua credibilidade.

\section{Figura 17: Vídeo B - Screenshot 2}

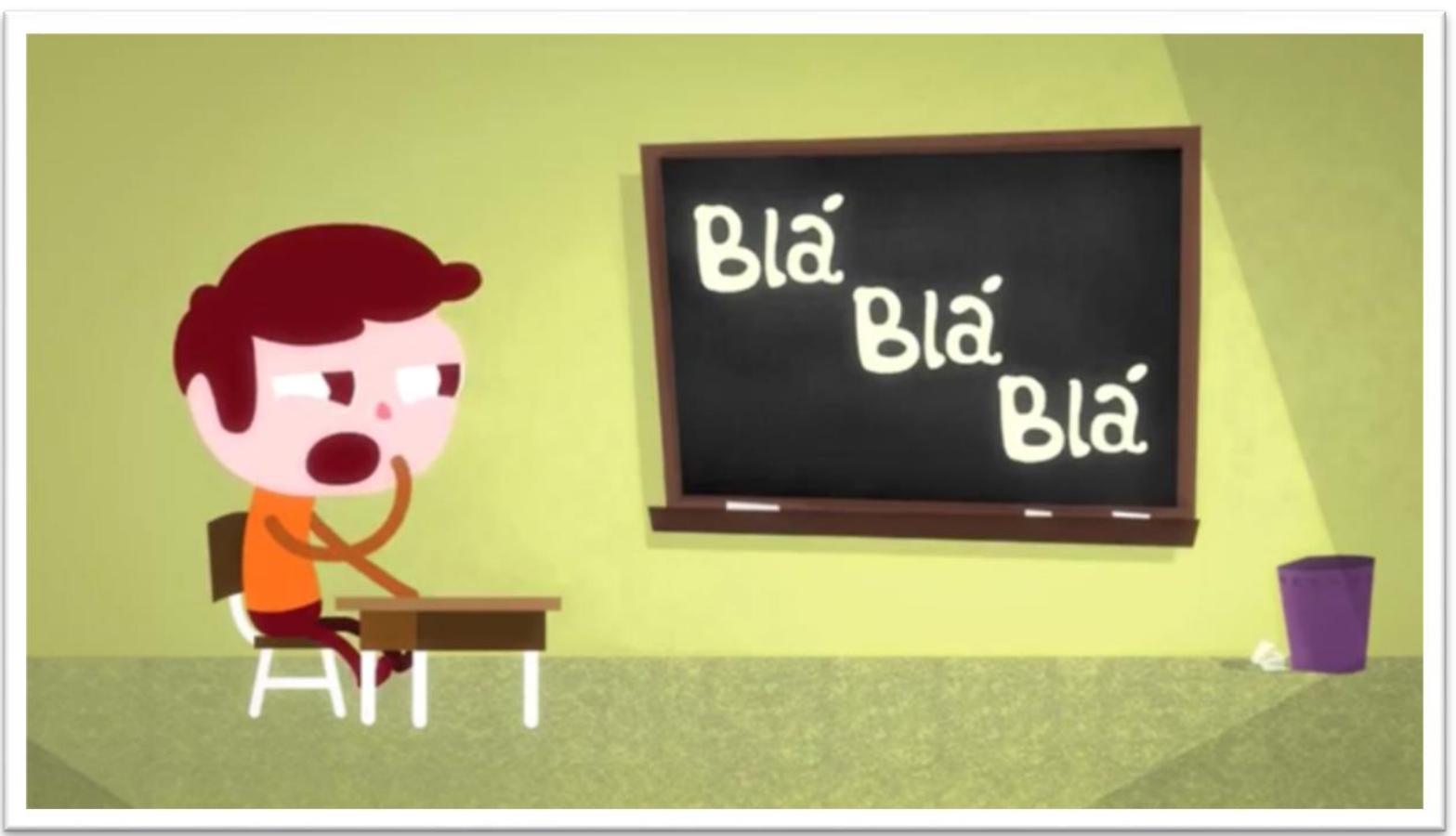


Já nos primeiros segundos do vídeo, o enunciador-especialista assume a posição daquele que fala a verdade, em nome da ciência. Deixa claro que se trata de uma argumentação que não pretende convencer sua audiência a querer, mas sim a dever estudar na instituição. O enunciador abre o vídeo desta forma:

"Este garoto quer aprender inglês e nunca mais esquecer. Mas para isso não vamos convencê-lo a vir para o [instituição]. Não. Vamos convencer o seu cérebro."

Ao dizer "não vamos convencê-lo (...), vamos convencer o seu cérebro", o enunciador opõe emoção e razão, querer pela motivação e dever pela lógica, e privilegia a razão. Desde ponto em diante, o enunciador apaga seu ponto de vista construindo uma fala sem terceira pessoa do plural, usando números e outros elementos verbais que pretendem se aproximar do discurso científico. Os elementos visuais também corroboram essa construção. As ações do vídeo funcionam como ilustração para os argumentos do enunciador-especialista, mas, mais fundamentalmente, a partir delas o especialista explica aquilo que o espectador vê, mas não entende.

\section{Figura 18: Vídeo B - Screenshot 3}

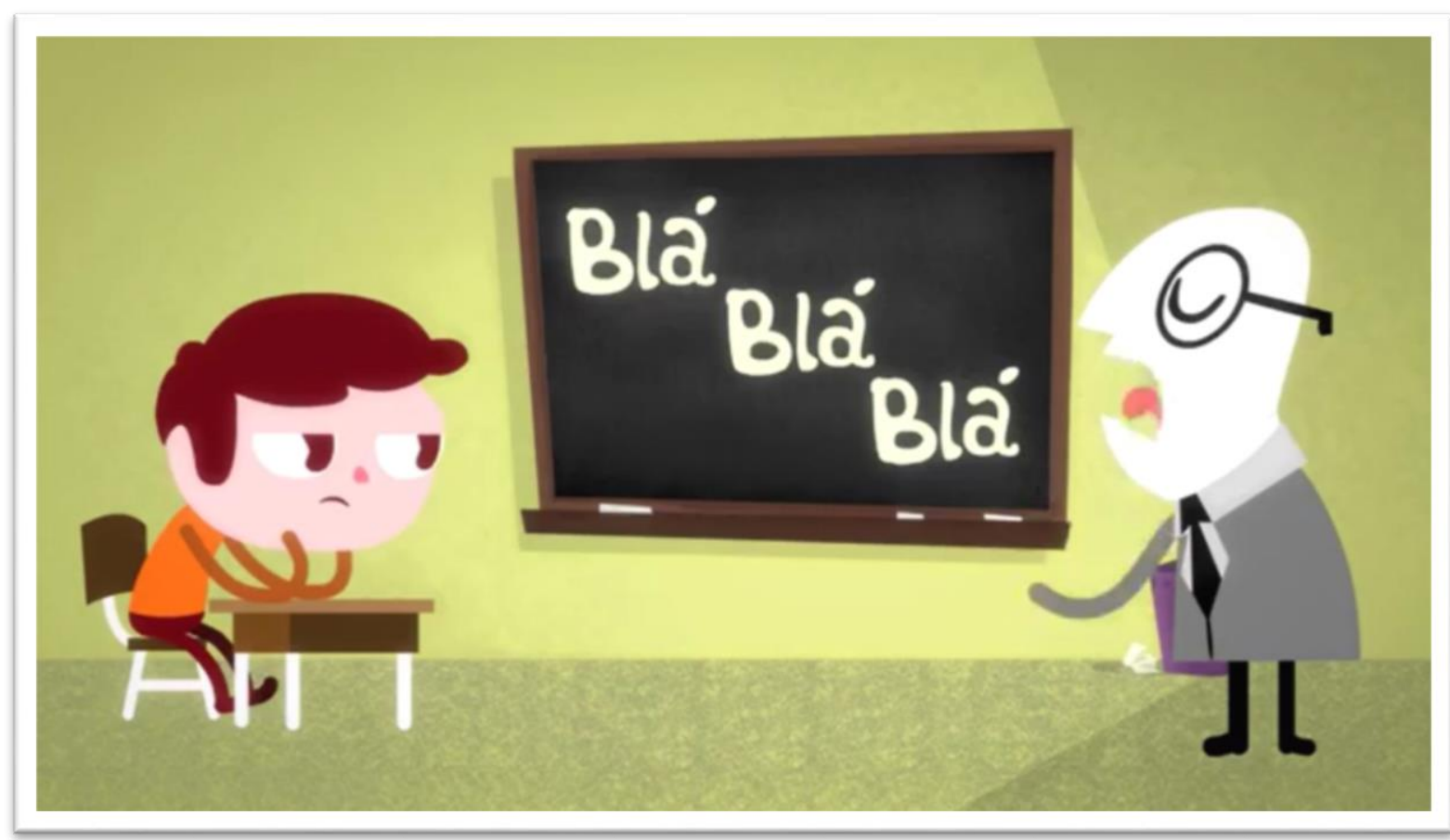

Além disso, o menino "inteiro" do início do vídeo passa a ser representado apenas pelo seu cérebro. Nessa espécie de metonímia, levando o espectador a tomar o cérebro pela pessoa, constrói-se uma figura de retórica na qual o especialista, o 
tempo todo, lembra o espectador de que seus argumentos são puramente racionais e devem ser lidos como um encadeamento de afirmações científicas e estabelecimento de relações e comparações lógicas. Dessa forma, o enunciador apaga a lógica da opinião, na qual um "fato" é pressuposto e tomado como ponto de partida para que ele explicite um universo de crenças que pode explicar o "fato", sendo que tal universo de crenças estaria sujeito à avaliação do outro. Ao aproximar seu universo de crenças do discurso científico, o enunciador-especialista submete o co-enunciador a posição de quem testemunha fatos e não de quem avalia opiniões.

\section{Figura 19: Vídeo B - Screenshot 4}

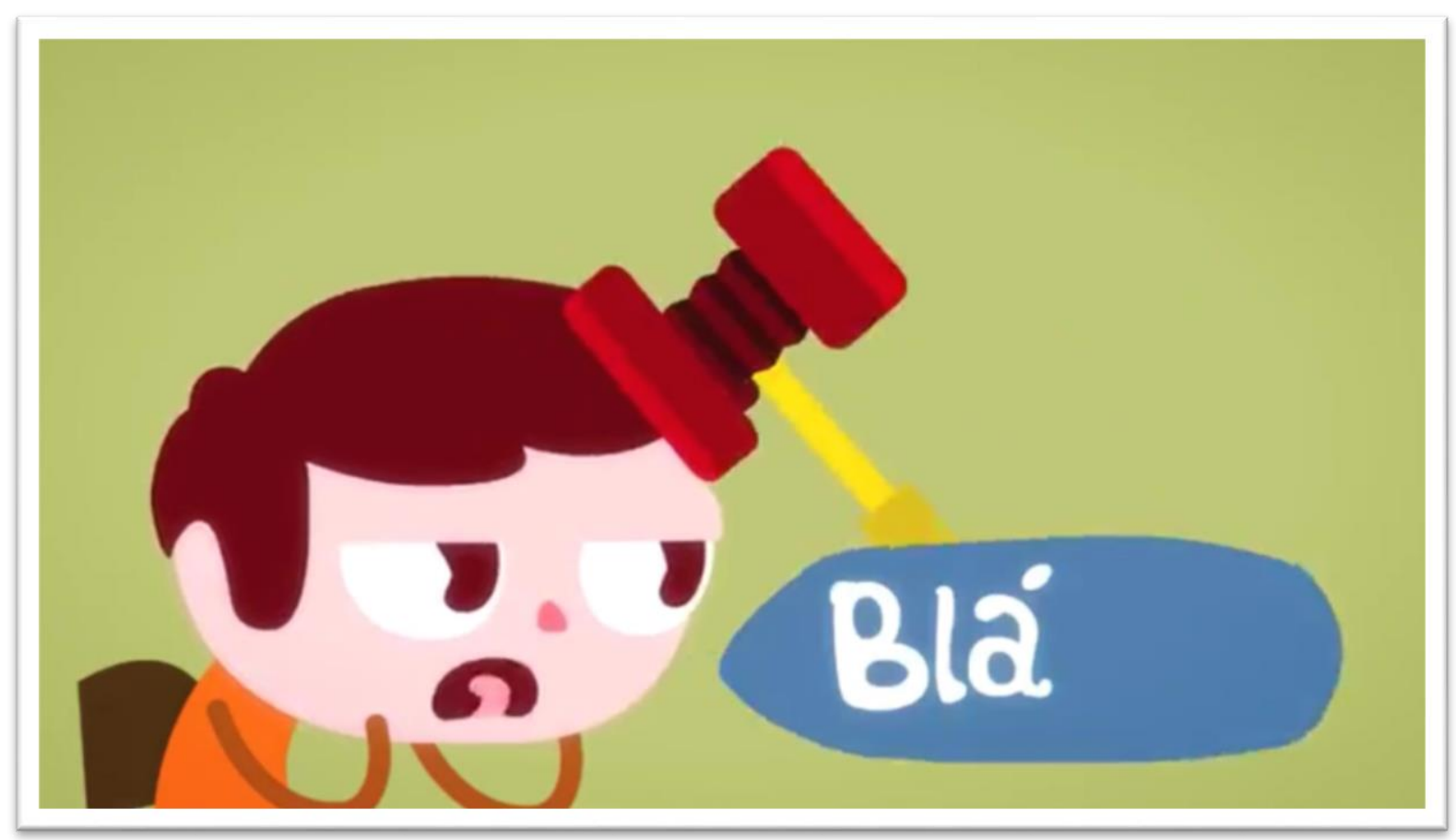

A posição de sujeito que fala em nome da instituição e da ciência está em relação com outra posição: a do sujeito que é tido como alguém que não sabe e deve observar para aprender. Os sujeitos se constituem um em relação ao outro; uma relação de posições de poder-saber desequilibradas. O sujeito que fala como um especialista narrador de documentário se relaciona com um sujeito que, diante do problema de como "aprender inglês e nunca mais esquecer", assiste, observa, testemunha a explicação científica que, em última instância, pretende convencer o cérebro (tomado pela pessoa) a ir para a instituição.

Em "use seu cérebro e venha para o [instituição]", o imperativo poderia levar a crer que o enunciador pretende impor a ação de ir à escola da instituição para 
espectador, atribuindo a si um estatuto de poder ou de autoridade para tal. De fato, o enunciador estabelece uma ação a realizar. No entanto, na forma como o discurso se constrói, o enunciador faz uma sugestão ou dá um 'conselho' ao espectador. O enunciador, ao atribui a si mesmo a qualidade de quem 'sabe' remediar a situação problema ("menino quer aprender inglês e nunca mais esquecer"), propõe que o espectador siga sua razão ("use seu cérebro") e faça aquilo que lhe é sugerido.

\section{Figura 20: Vídeo B - Screenshot 5}

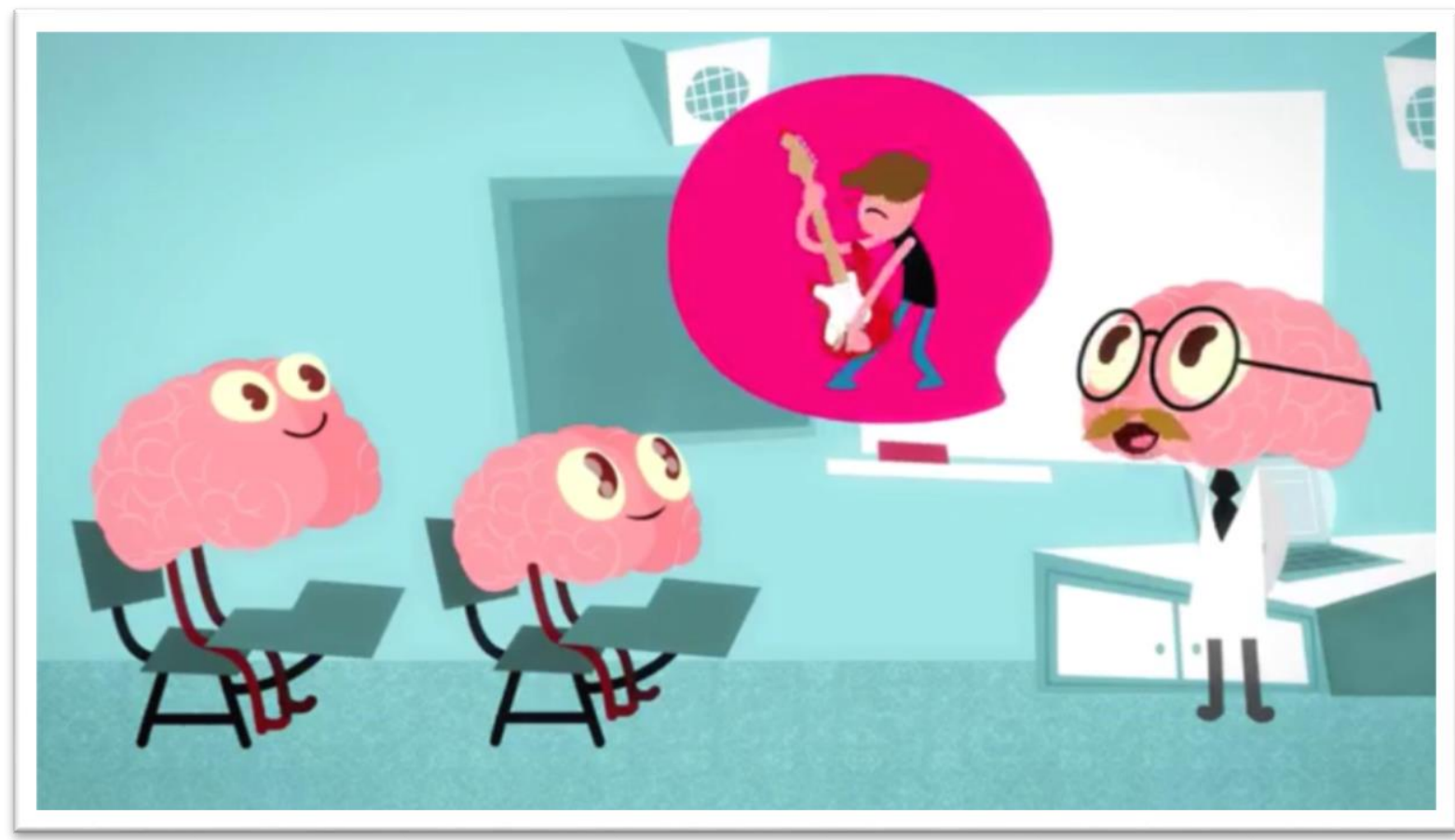

Nesse sentido também são construídas representações do aluno e do professor. O professor é aquele que sobriamente fornece "o" modelo que deve se aproximar da idealização de um falante nativo: "o cérebro vivencia situações e diálogos que acontecem no dia a dia do americano". Ele controla a direção e o ritmo da aula. É o responsável pelo aprendizado ao se posicionar como principal fonte de input na língua-alvo e oferecer estímulos verbo-visuais que são naturalmente "processados" e "internalizados tanto na memória de curto prazo quanto na de longo prazo". A resposta do aluno aparece como uma consequência das ações do professor ao apresentar modelos de linguagem. O aluno, assim, é representado como alguém que deve reproduzir os modelos de linguagem idealizados. Ele é tido como um organismo que pode ser dirigido por técnicas baseadas em estímulos sensoriais 
verbais ou não verbais, até que o idioma seja incorporado: "o novo idioma é absorvido".

O enunciador mostra uma forma ineficiente de aprender o idioma e a compara com a forma da instituição que representa. Na construção da representação das duas salas de aula, há mais semelhanças que diferenças.

\section{Figura 21: Vídeo B - Screenshot 6}

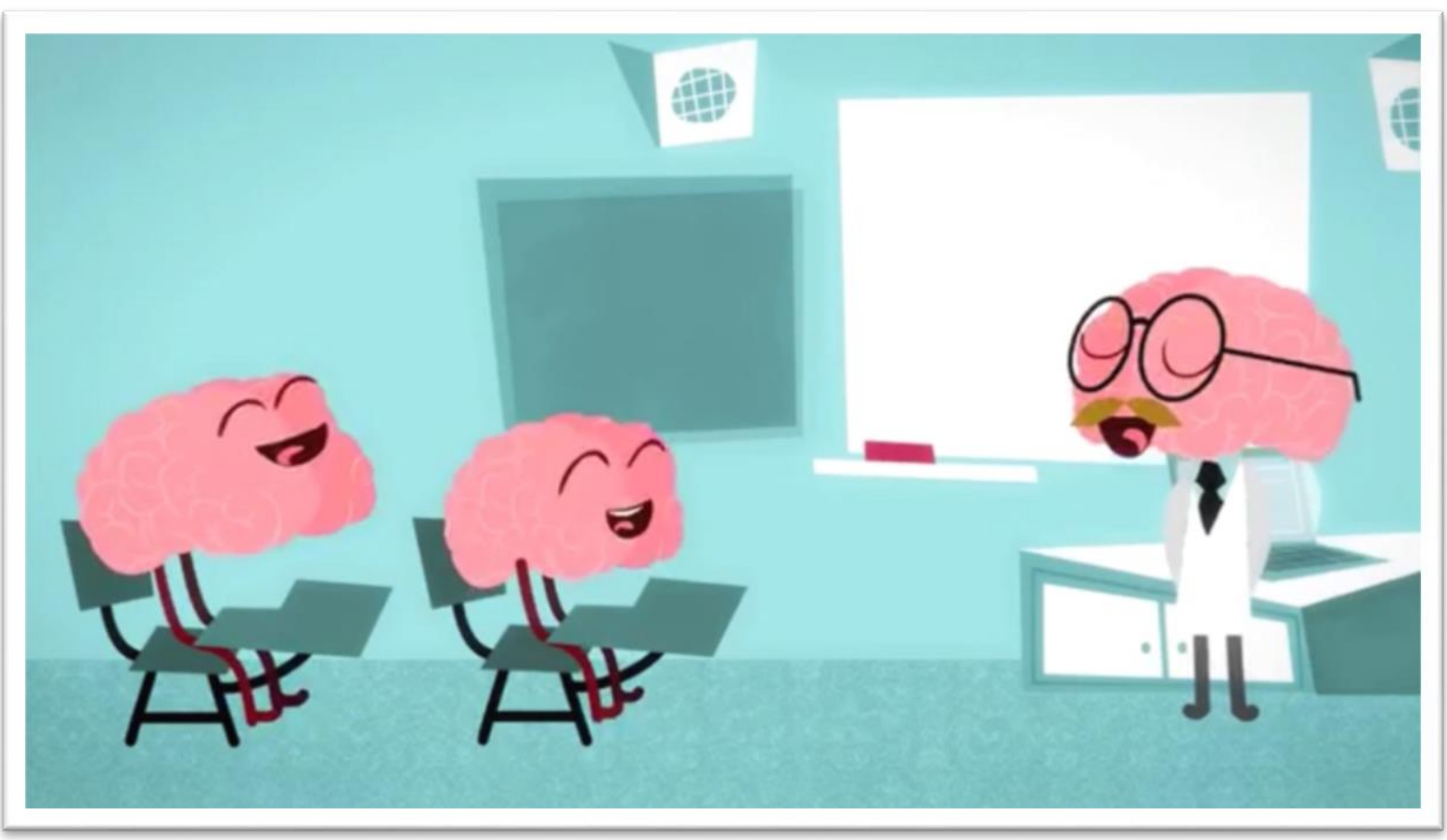

Nas duas representações, a sala de aula tem o professor no centro do processo, sendo ele aquele que oferece modelos a serem incorporados por estímulos. Além disso, nos dois casos o professor parece estar explicando algo, mas não parecem estar falando com os alunos. Parecem estar falando para os alunos. A postura corporal do professor e os olhos cerrados, nos dois casos, representa um professor centrado em si, convicto de suas ações. Além disso, espera-se o uso da língua com a precisão idealizada do nativo e ela é conseguida por estimulação e não por explicação. Pressupõe-se aprendizagem implícita e não explícita. Ou seja, pressupõe-se que a "aquisição de conhecimento que acontece independente das tentativas conscientes para aprender na ausência de conhecimento explícito sobre o que se adquiriu" (REBER, 1993). Essa representação se consolida tanto pelo discurso não-verbal (as imagens conforme a descrevemos) quanto verbal, principalmente 
quando o enunciador-especialista afirma que "o novo idioma é absorvido de forma gradual e intuitiva".

\section{Figura 22: Vídeo B - Screenshot 7}

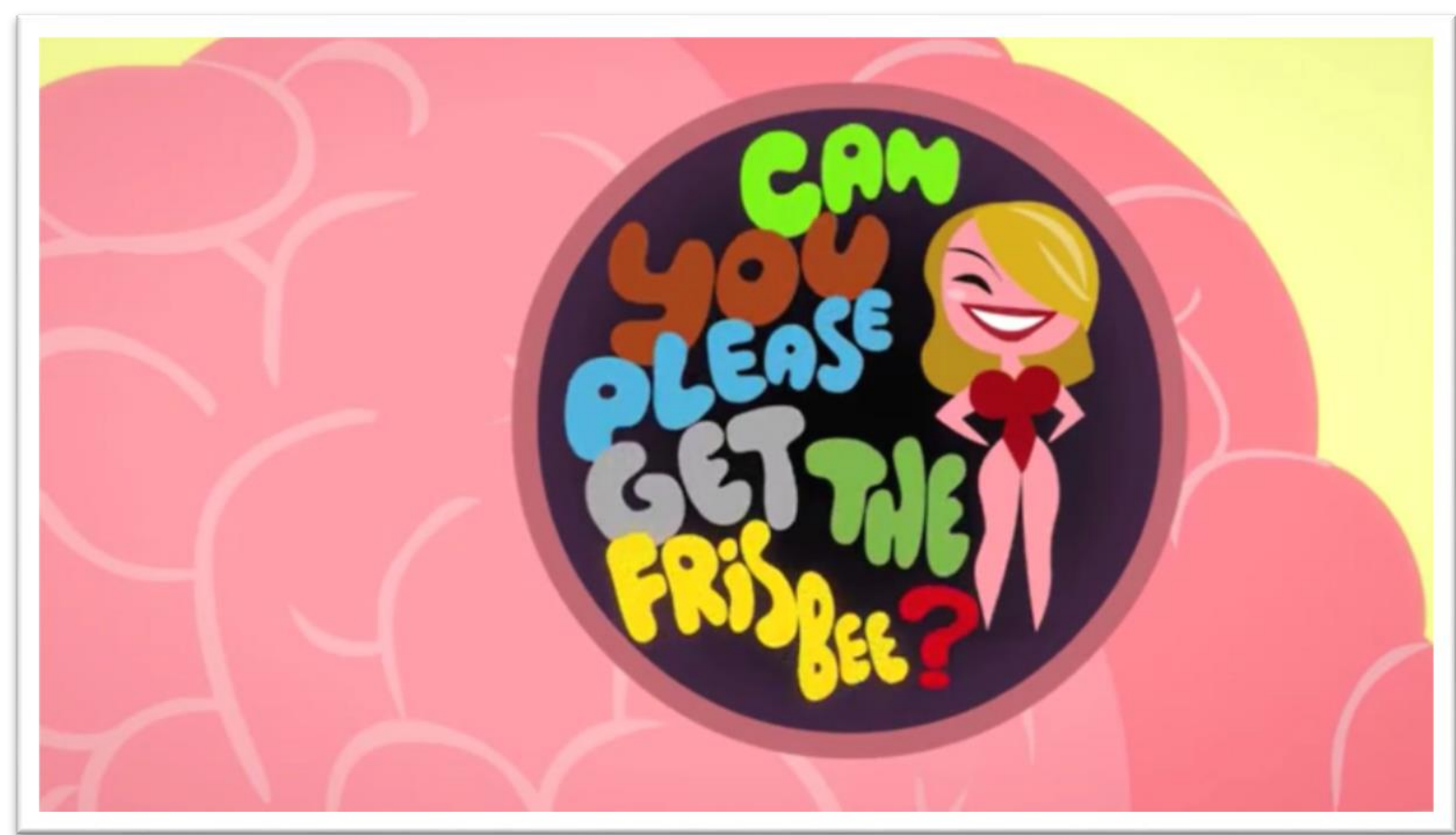

Com relação às diferenças, podem ser resumidas em duas: ambiente e recursos; e participantes da interação. Dois ambientes contrastam, sendo que um representa o tradicional e outro, o atual. Este é tido como o ambiente da instituição e o primeiro, como o ambiente do outro, de outra instituição, das outras instituições. A sala de aula tradicional é monótona, chata, desestimulante. As cores que a compõem são em tom amarelado e cinza; o quadro usado pelo professor tem conteúdo escrito a giz e tem aparência de algo antigo; a postura corporal do aluno indica tédio e a do professor uma convicta sobriedade e formalidade; e, finalmente, o aluno aparece sozinho em sala.

A sala de aula da instituição é o avesso desses traços. É divertida, alegre, feliz e com recursos tecnológicos mais avançados. As cores são mais alegres, com predominância de tons de azul que contrastam mais claramente com o amarelo do cenário anterior; há dois alunos, o que rompe com a representação de solidão; há elementos de modernidade, como o quadro branco com marcador, as caixas de som e o computador; o professor veste branco e não cinza; todos sorriem e riem. 
A representação da interação, assim, é apenas sutilmente diferente nas duas salas de aula. Na sala de aula tradicional, o aluno usa um dos sentidos de cada vez, "somente os olhos" ou "somente os ouvidos". Além disso, o aluno interage apenas com o professor. Na sala de aula da instituição, o aluno usa a visão e a audição ao mesmo tempo: "os olhos veem as imagens, os ouvidos escutam os diálogos". Além disso, há elementos de tecnologia em ambiente que é interessante e amigável, não apenas pelo clima descontraído, mas também por assuntos tidos como interessantes, como característica inata, e pelo fato de os alunos poderem ouvir e ver uns aos outros:

"a interação com o cérebro de outros alunos e professores faz parte do processo de aprendizado". (vídeo B)

Naquilo que é invariável, a interação é tida como um fluxo de ações ou uma relação de causalidade entre ações que constituem um sistema fechado. O professor estimula, o aluno responde. O professor expõe o aluno a padrões de uso da língua e o aluno processa isso como conjunto de informações que impressionam seus olhos e ouvidos e, então reproduz os padrões. Ainda mais detalhadamente, o professor estimula a visão, a audição e a percepção do aluno com certos padrões de uso da língua alvo, que por sua vez faz associações entre os elementos verbais e não verbais no evento comunicativo para viabilizar o armazenamento dos padrões na memória de curto e longo prazo e, finalmente, reproduz o padrão de uso da língua ao qual foi exposto. Não importa o quanto aumentemos o processo em grau de detalhamento ou complexidade da explicação, ele sempre poderá ser resumido em uma informação que viaja linearmente de uma instância a outra: sempre poderá ser resumida a "o professor estimula, o aluno responde". 


\section{Figura 23: Fluxo de interação do vídeo B}

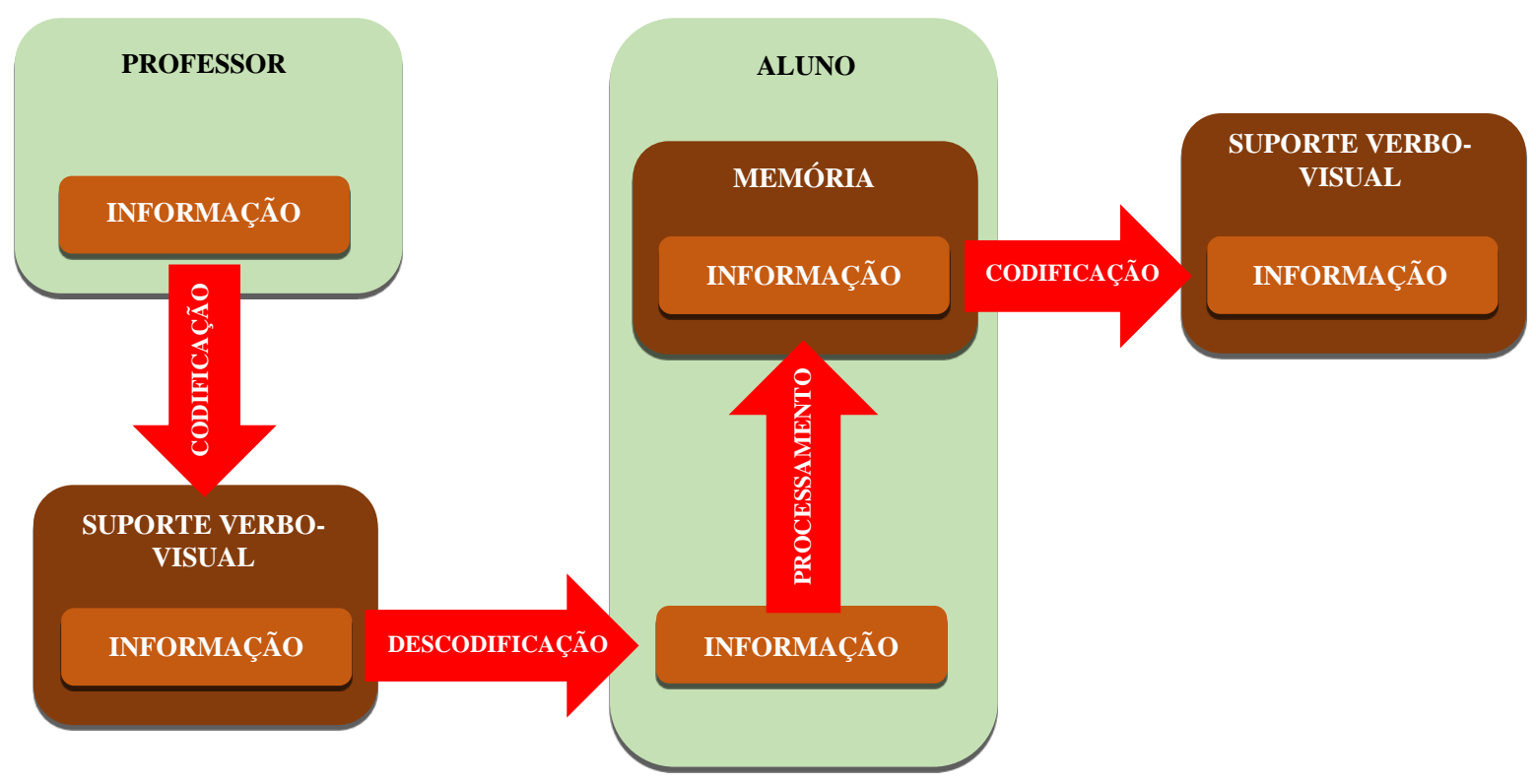

Naquilo que é distintivo entre a interação na sala de aula tradicional e na da instituição, há a oposição entre o marasmo, o tédio, apatia e a animação, alegria, atividade. Como dissemos, o ambiente é descontraído, alegre, divertido. Se na representação da sala de aula tradicional é admitido que o processo de aprendizagem possa ser chato e árduo, na sala de aula da instituição o processo é divertido e prazeroso. Em "a interação com o cérebro de outros alunos e professores faz parte do processo de aprendizado e ajuda você a absorver o idioma naturalmente", todos em aula riem e se divertem no exato momento em que o especialista diz "faz parte do processo de aprendizagem".

Assim como apontamos na análise do primeiro vídeo, aqui há um aspecto aparentemente contraditório. Os modelos de interação nas duas salas de aula retratadas no vídeo são estruturalmente iguais. O discurso sobre esse modelo de interação não é institucionalizado pela mídia. O texto midiático, nesse caso, retoma e reitera representações de uma ideia de interação conforme foi sedimentada por uma perspectiva comportamentalista, predominante durante muitos anos entre as abordagens e métodos de ensino de inglês.

Além disso, a supervalorização do entretenimento e da interação como atividade prazerosa também pode ser apreendida na análise desse segundo vídeo. Nos dois casos, não é a interação em si que faz ou pode fazer a injunção do discurso 
publicitário dos cursos mais atraente ou influente, mas sim as características da diversão e do entretenimento associadas a ela.

\section{Figura 24: Vídeo C - Screenshot 1}

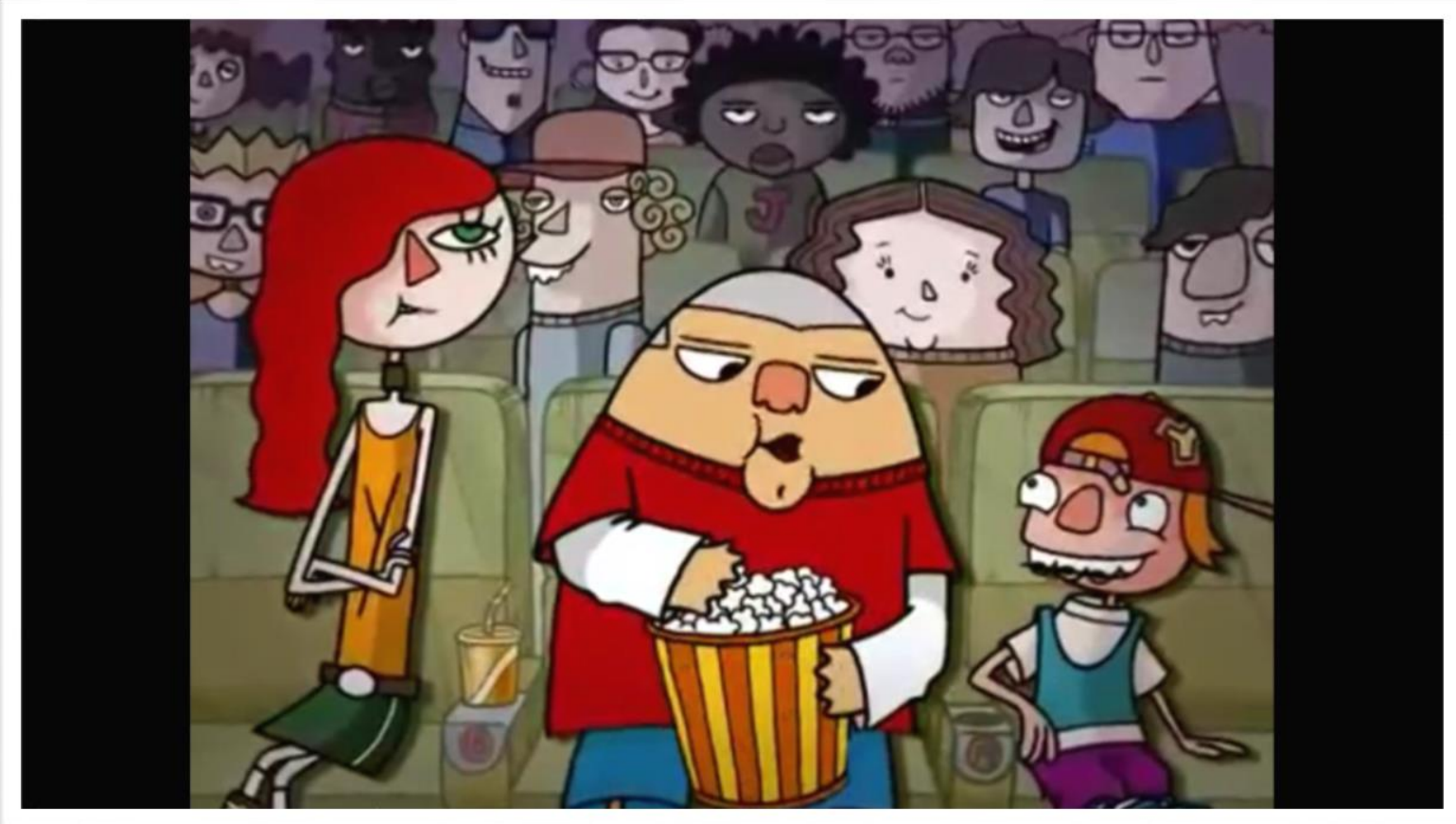

Figura 25: Vídeo C - Screenshot 2

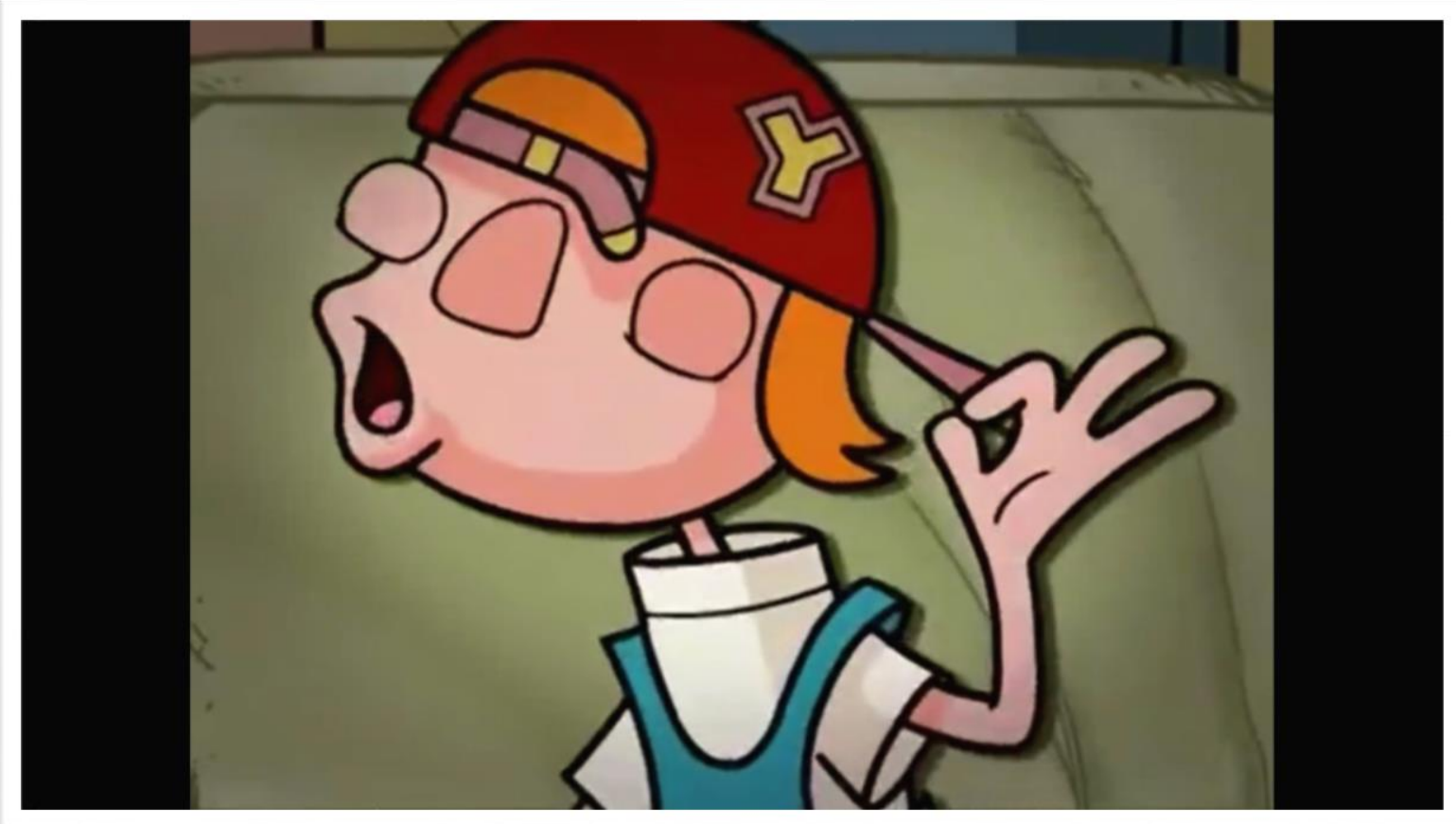


Nesse sentido, é possível afirmar que, de fato, parece haver uma regularidade enunciativa na mídia publicitária sobre a representação da interação no processo de ensino e aprendizagem de inglês, bem como sobre a idealização da interatividade como atividade de diversão e entretenimento. Por outro lado, não é possível afirmar categoricamente que essa regularidade esteja construindo ou constituindo uma memória discursiva com esses traços. Na verdade, argumentamos que essa recorrência seja uma reiteração de memórias discursivas, ressignificando-as principalmente ao articular seus traços aparentemente contraditórios.

Em uma terceira campanha publicitária, há dois momentos. Num primeiro momento, o enunciador é de difícil apreensão porque não há narrador ou voz que possa ser tomada como "aquele" que fala na ou através da peça publicitária. O sujeitoespectador é constituído na posição daquele que fica diante de um espetáculo.

\section{Figura 26: Vídeo C - Screenshot 3}

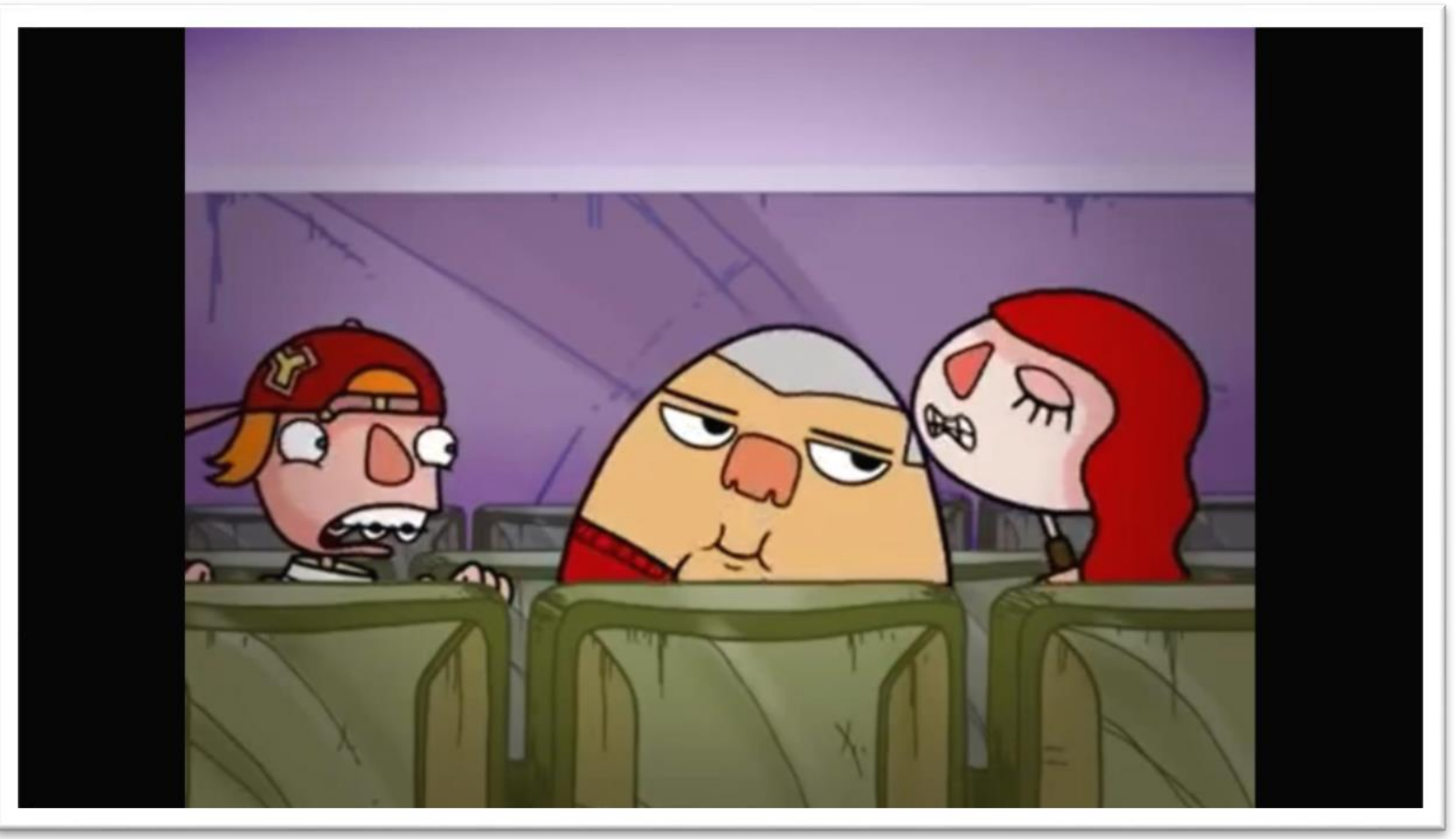

Desde o início, todos os elementos indicam que se trata de algo mangado, divertido, achincalhado. O vídeo é uma animação de traços estereotipados e escrachados, sem pretensão de realismo. O efeito cômico se dá justamente pelo exagero desses traços. O diálogo se articula com os elementos visuais para constituir uma anedota: uma sequência curta com estrutura narrativa, na qual o diálogo entre as personagens se dá em uma situação mundana (na qual conseguimos nos colocar), 
e que termina em uma fala (punch line) que pretende causar risos com um deslocamento de sentido e final surpreendente. O objetivo, enfim, é entreter o interlocutor.

Ao mesmo tempo, também desde o início, tal narrativa gira em torno da personagem que ensina para as outras como se diz o nome de dois objetos daquele cenário e uma ação (implícita) em inglês: stadium, loveseats e kiss. O ensinar do personagem é explícito e intencional:

- Aí Pudim, você sabe como se chama essa sala em inglês?

- Como?

- Stadium!

Em seguida, a personagem ensina outra palavra:

- E essa cadeira aqui, e essa cadeira aqui... Sabe como chama? Loveseats!

\section{Figura 27: Vídeo C - Screenshot 4}

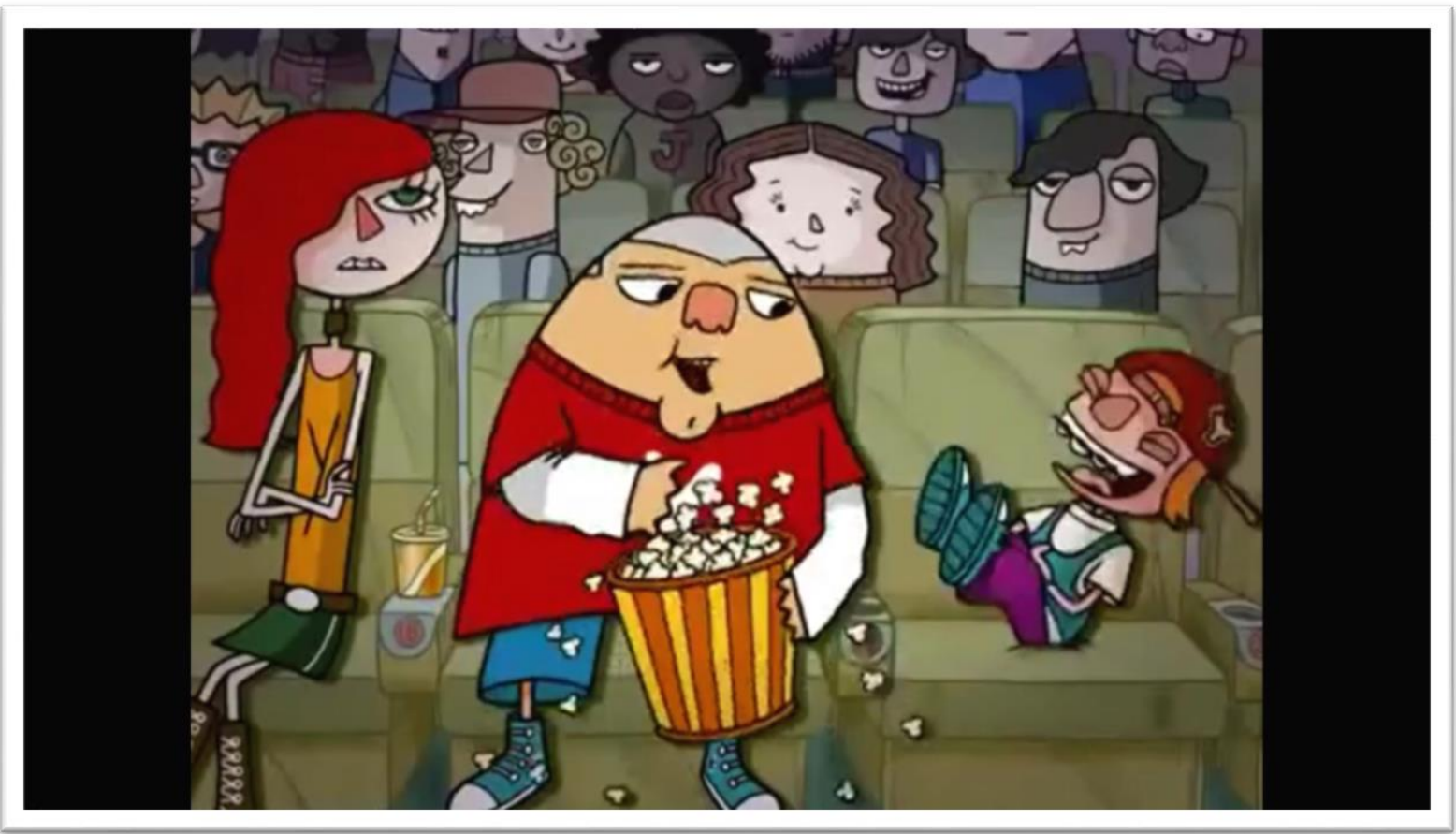

A intenção de ensinar também é marcada pela postura da personagem e pelo tom de voz. A postura da personagem não é a de quem simplesmente conta o que é, mas de quem modela a linguagem e se posiciona como referência. O gesto indica sua preocupação em ser o mais preciso possível ao modelar a linguagem e o ritmo de sua fala expressa um pedido de "atenção", associada a certo tom, como "observe e aprenda". 
O enunciador, evidentemente, não corresponde a uma das personagens, tampouco a seu conjunto. O enunciador corresponde à posição daquele que conta a anedota através das personagens.

\section{Figura 28: Vídeo C - Screenshot 5}

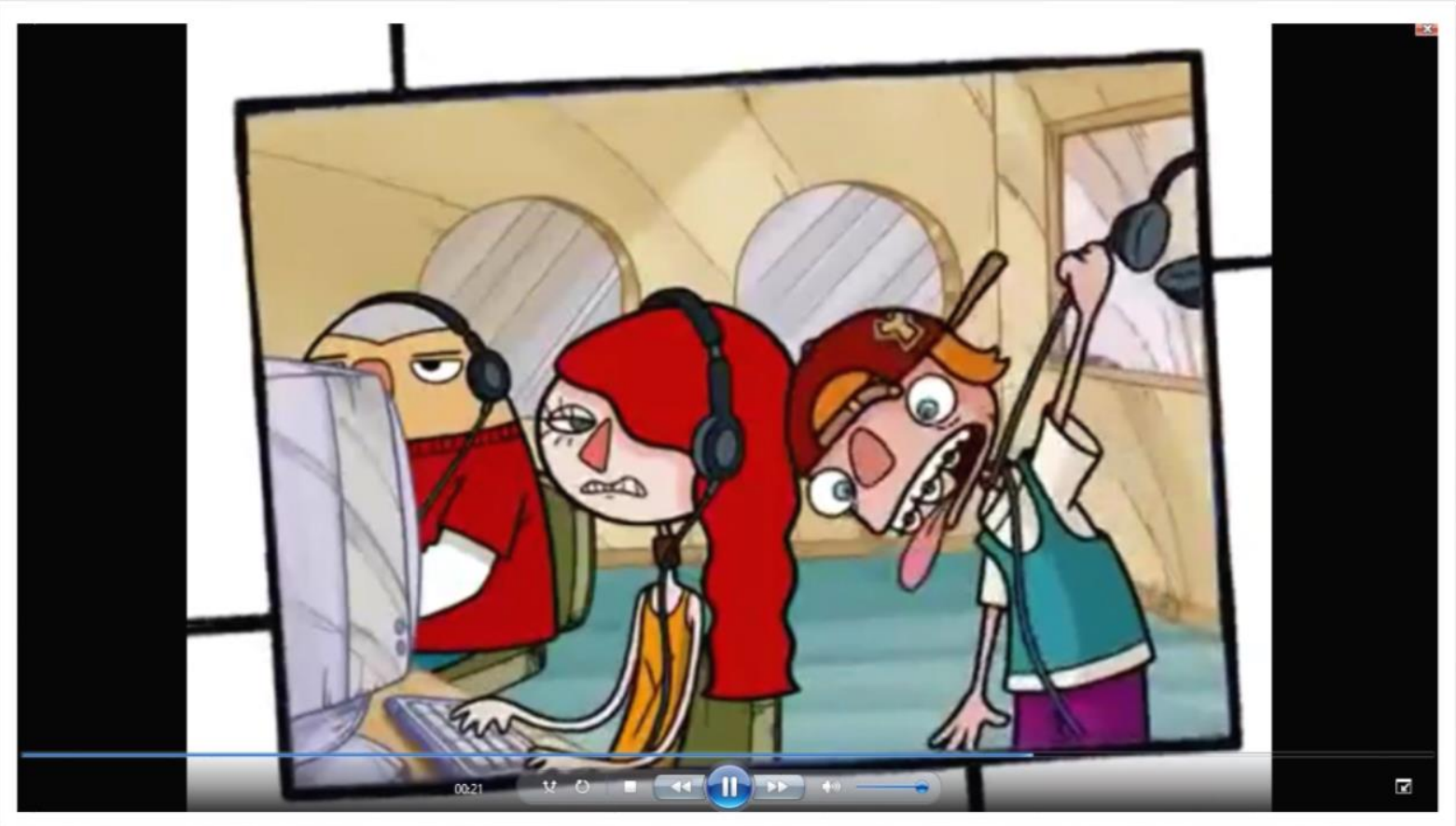

Talvez seja um salto de interpretação muito grande dizer que tal posição constitua um sujeito-professor, mas não podemos deixar de apontar para as evidências. O sujeito-espectador está diante de uma peça publicitária, mas a estrutura da narrativa o leva a se posicionar como alguém que poderá aprender três palavras em inglês. As marcas linguísticas, o tom e a postura das personagens não se dirigem apenas umas às outras, mas também (e principalmente) ao espectador. É para ele que a anedota é contada. Além disso, logo após a anedota, ou seja, logo após o espectador ter aprendido três palavras em inglês, o narrador se dirige a ele clarificando que se trata de um jeito de ensinar inglês.

Não se trata de um jeito qualquer de ensinar inglês, mas de "um jeito fácil". Não apenas fácil, mas um jeito de ensinar em que o aluno aprende brincando e se divertindo: "Aqui ele aprende brincando, cantando e na internet". Implicitamente, mais uma vez, estamos diante de uma representação do processo de aprendizagem como algo indolor, bem-humorado, divertido e que encontra nesses traços sua "essência". 
A sala de aula não é aquela que ensina e diverte, mas aquela que ensina por meio da diversão.

\section{Figura 29: Vídeo C - Screenshot 6}

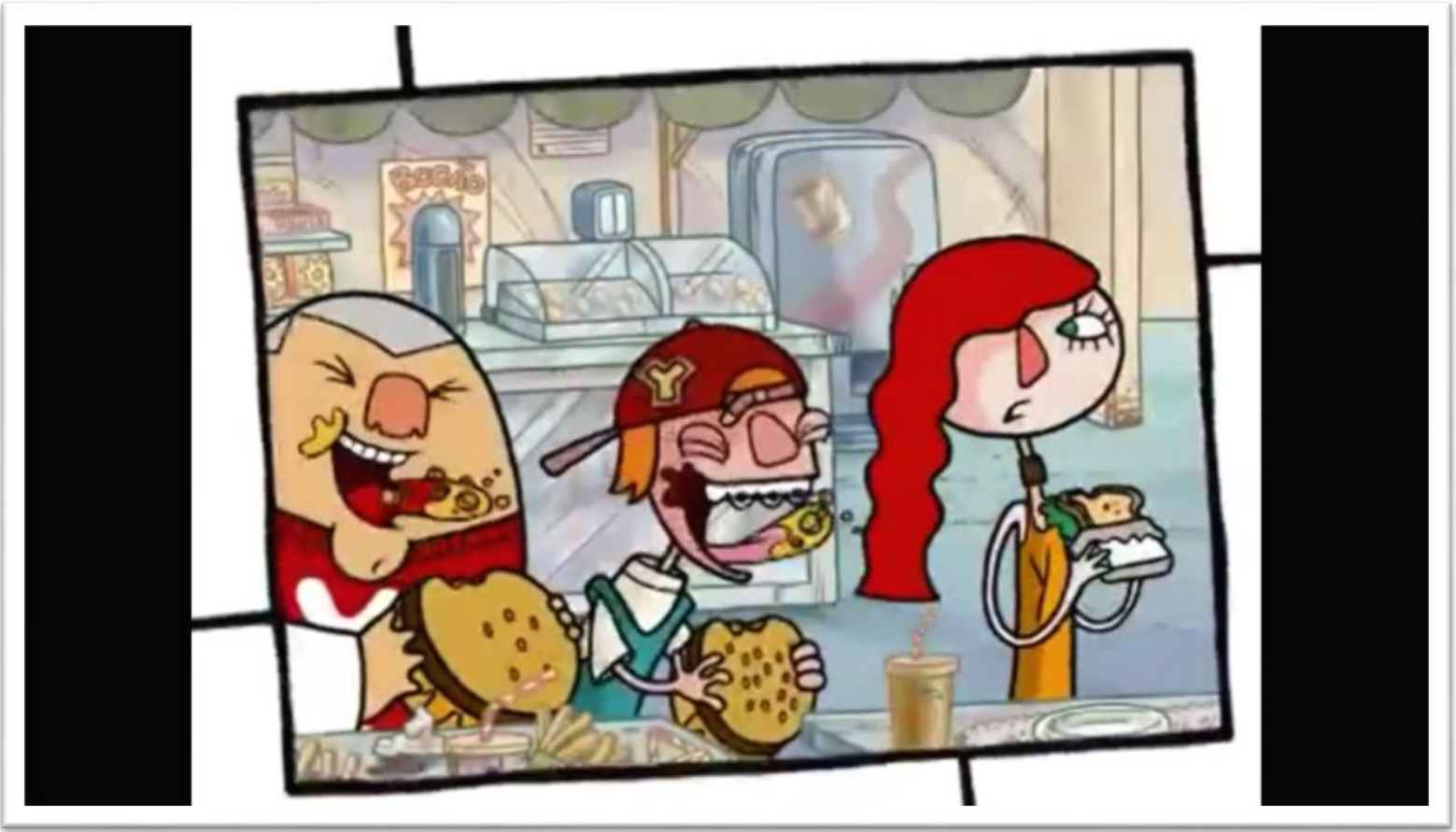

Quando termina a anedota e surge a voz de um narrador, o texto mais explicitamente estabelece uma relação de influência em relação ao seu interlocutor, marcada na voz do narrador em "quer um jeito fácil de ensinar inglês para seu filho?" e nos sinais que as personagens seguram ao final do vídeo com a mensagem "venha já".

Apesar do imperativo que estabelece uma ação a realizar, não é exato afirmar que se trata de uma injunção ou imposição para que o sujeito-espectador vá ao estabelecimento. Em "quer um jeito fácil de ensinar inglês para seu filho?", o texto realmente estabelece uma ação a realizar e supõe o desejo do espectador em ter tal ação realizada. Mas as marcas linguísticas apontam, incluindo a entonação, para um tom de proposta. $\mathrm{O}$ enunciador atribui a si a posição daquele que tem o poder para realizar (ensinar de jeito fácil e divertido) e atribui ao espectador a posição daquele que precisa decidir. $\mathrm{O}$ espectador recebe a proposta e se vê na posição daquele que deve decidir se aceita ou recusa a proposta. O efeito de sentido conduz à ideia de que se o espectador precisa de ajuda para que seu filho aprenda inglês de um jeito fácil e divertido, o enunciador pode ajudar definitivamente: "No [nome da marca], seu filho 
aprende inglês e espanhol de verdade". Assim, nesse vídeo também aprendemos na análise que a idealização da interação é reiterada e ressignificada.

Nesses três primeiros vídeos focalizamos o modo de funcionamento da mídia pela reiteração, mas a memória também é feita de esquecimentos e silêncios (GRIGOLETTO, 2011, p. 306). Nosvídeos, a ênfase em sentidos da discursividade de determinadas perspectivas do ensino e aprendizado de inglês e da discursividade espetacular do mercado (neoprodutivistas) sobre interação acabam silenciando sentidos de outras discursividades, principalmente de aspectos culturais e educacionais. Esse modo de funcionamento não é específico dos vídeos em análise. "A mídia [...] ocupa um lugar de grande destaque e de constituição de memórias na nossa sociedade, construindo realidades ou silenciando sentidos num dado momento histórico, a partir de suas condições de produção" (CARMAGNANI, 2014, p. 343). Nos vídeos em análise, as três instituições que anunciam seus cursos se filiam a diferentes perspectivas de metodologias de ensino de inglês, cada uma com suas específicas implicações em termos educacionais. Essas diferenças são homogeneizadas pelo silenciamento de seus enunciados e pela reiteração dos enunciados que analisamos.

Não encontramos evidência de modos de operação dos vídeos publicitários que propriamente engendrassem, construíssem ou impusessem memórias discursivas, mas a análise desses três primeiros vídeos permite afirmar que a mídia de fato se constitui como um lugar de memória, operando sobre a memória discursiva tanto pela reiteração quanto pelo esquecimento. A reiteração articula e ressignifica inclusive enunciados contraditórios, escamoteando os conflitos dessas contradições e apresentando os enunciados como memorizados e sedimentados. Ao mesmo tempo, silencia outros enunciados da discursividade das instituições que anunciam seus cursos nas peças publicitárias analisadas.

A campanha de 2016 de outra rede de escolas de idiomas é exemplar para analisarmos a articulação entre as características que são amplamente atribuídas à interação no discurso acadêmico e os valores neotecnicistas e neoliberais que permeiam as representações da sala de aula de língua inglesa. 


\section{Figura 30: Vídeo D - Screenshot 1}

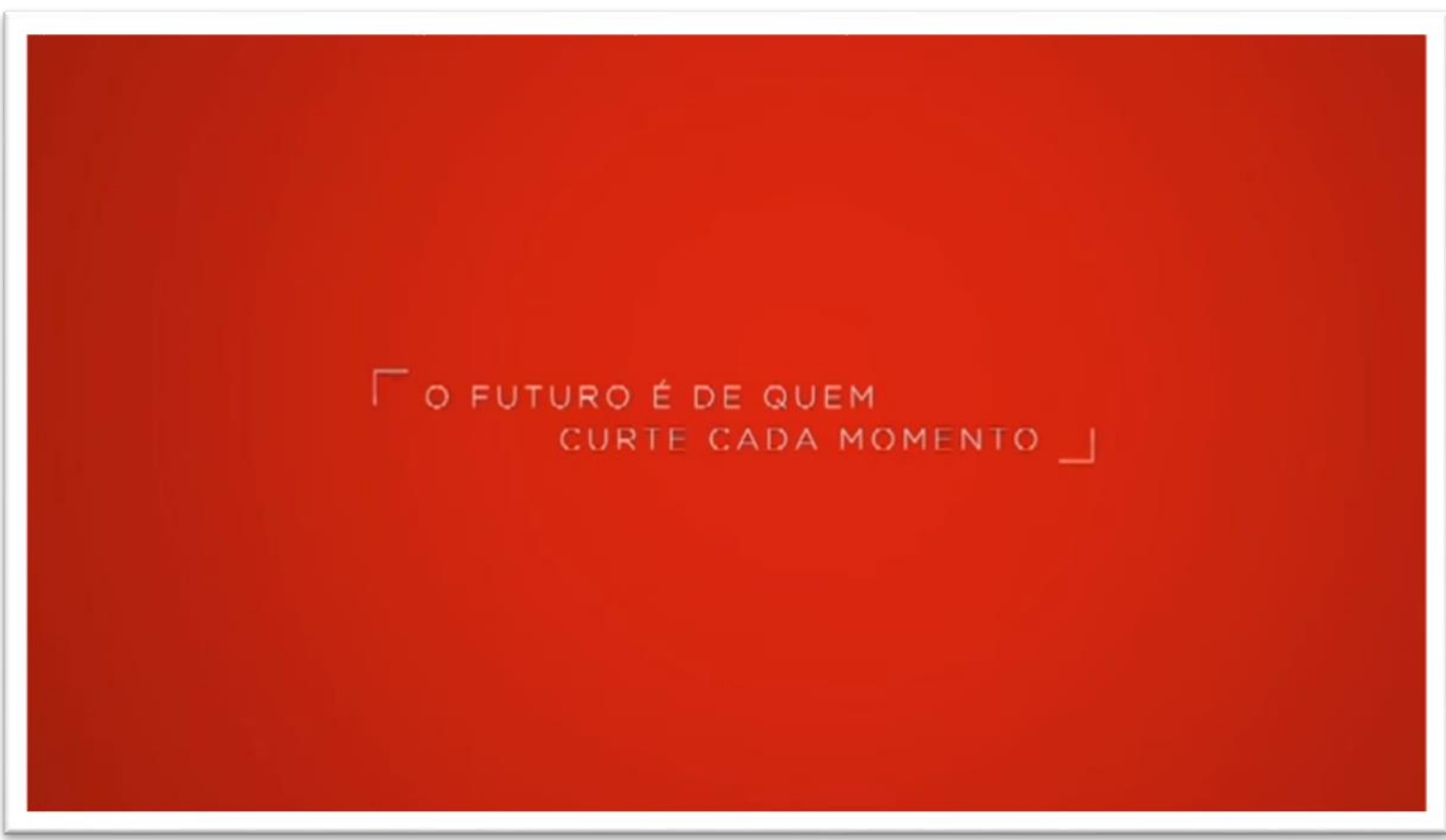

$\mathrm{Na}$ abertura do vídeo, o enunciado "o futuro é de quem curte cada momento" é destacado, e a ele seguem cenas de jovens se divertindo em diversas atividades, como canto, dança, interação com tecnologias de comunicação, e prática de esportes. Esse enunciado antecipa muito da jovialidade evocada durante 0 vídeo, principalmente pela expressão da tomada do futuro, pelo verbo "curtir", pela ênfase em "cada momento", e pela fonte e layout da abertura.

O "futuro" é coisificado no sentido de que é expresso como algo sobre o que é possível ter posse, em "o futuro é de quem (...)", e presume que haja sujeitos que queiram ser donos ou dominarem o futuro. Ao mesmo tempo, ao longo do vídeo não são representadas relações de dominação ou explícitos estados de posse. São representados jovens se divertindo e interagindo uns com os outros e com tecnologias. Isso nos permite interpretar que ter o domínio do futuro é querer e poder "curtir", com ênfase no querer. Essa ênfase também está presente em trechos da letra da música do vídeo nos enunciados "this is your life, this is your call", e "the world is yours to take". O chamado e o mundo a espera de ser tomado explicitam a necessidade do sujeito tomar a decisão de responder ao chamado, de fazer algo para tomar o mundo. Mas não é qualquer coisa que deve ser feita. É preciso curtir. É preciso interagir e se divertir. 
O "curtir" talvez nunca tenha sido tão popular antes do Facebook e outras redes de sociais e remete a uma jovialidade entre o adolescente e o adulto. Por um lado, em uma linguagem adolescente casual o "curtir" pode mais recorrentemente expressar "aproveitar" ou "desfrutar". "O futuro é de quem desfruta cada momento" talvez anunciasse um tom mais sóbrio, mais sério, ou mais "adulto". Por sua remissão às práticas discursivas amplamente reproduzidos a partir do Facebook, o "curtir" remete ao meio digital, especialmente às tecnologias da comunicação e, em última instância, à interação social. No Brasil e em muitos outros países, o Facebook não é tão popular entre os adolescentes, sendo que a massiva maioria de seus usuários são adultos $^{58}$. Também remetendo a esse universo de interação social e tecnologias de comunicação, o "curtir" não expressa apenas o sentido de tirar o máximo proveito de algo que se apresenta a nós, mas também, e talvez principalmente, a nossa tomada de decisão e nossa (re)ação ou interação com aquilo se apresenta a nós e com aquilo que buscamos.

Também contrastando o dito e o não dito, "curtir cada momento" silencia o "curtir a vida" e o "curtir todos os momentos". Em um momento histórico de neoliberal, no qual o individualismo é valorizado em uma lógica toyotista ("just in time philosophy") e "o todo" é uma homogênea soma de unidades, "curtir a vida" expressa mais uma atitude ou posicionamento e menos um fazer específico ou coletivo de ações. No neoliberalismo, o que é a vida senão um coletivo de momentos? E porque então não curtir "todos os momentos"? Enquanto o "todos os momentos" pode remeter ao todo da vida, o enunciado "o futuro é de quem curte cada momento" enfatiza a diferença e a unidade desses momentos.

A fonte e o layout dessa cena inicial do vídeo também expressam jovialidade porque se submetem ao que é amplamente tido como tendência em design de interfaces e iconografias digitais. A fonte simples, de traço estreito, e o fundo plano de uma só são características do estilo que é conhecido como flat design. Trata-se de uma tendência de design de interface que faz o mínimo uso de elementos estilísticos que criam efeito tridimensional (daí o nome flat) e que usa poucos e simples elementos

\footnotetext{
58 De acordo com o portal G1 da Rede Globo, "Redes como Instagram, Twitter e aplicativos de mensagens como WhatsApp estão entre os favoritos nas telas dos smartphones dos adolescentes": http://g1.globo.com/tecnologia/noticia/2013/11/jovens-brasileiros-trocam-facebook-por-aplicativos-demensagens.html.
} 
gráficos e tipográficos, e cores maciças. Essa abertura do vídeo tem um traço destoante dessa tendência dominante, que é a cor com gradiente. Este traço não é considerado predominante, mas é tido como uma tendência emergente, com diversos sites especializados celebrando "a volta do gradiente". A cor vermelha, por fim, ao mesmo tempo associa esses traços à marca, já que se trata de sua cor predominante, e anuncia o tom afetivo do vídeo, porque a cor também é associada às paixões.

\section{Figura 31: Vídeo D - Screenshot 2}

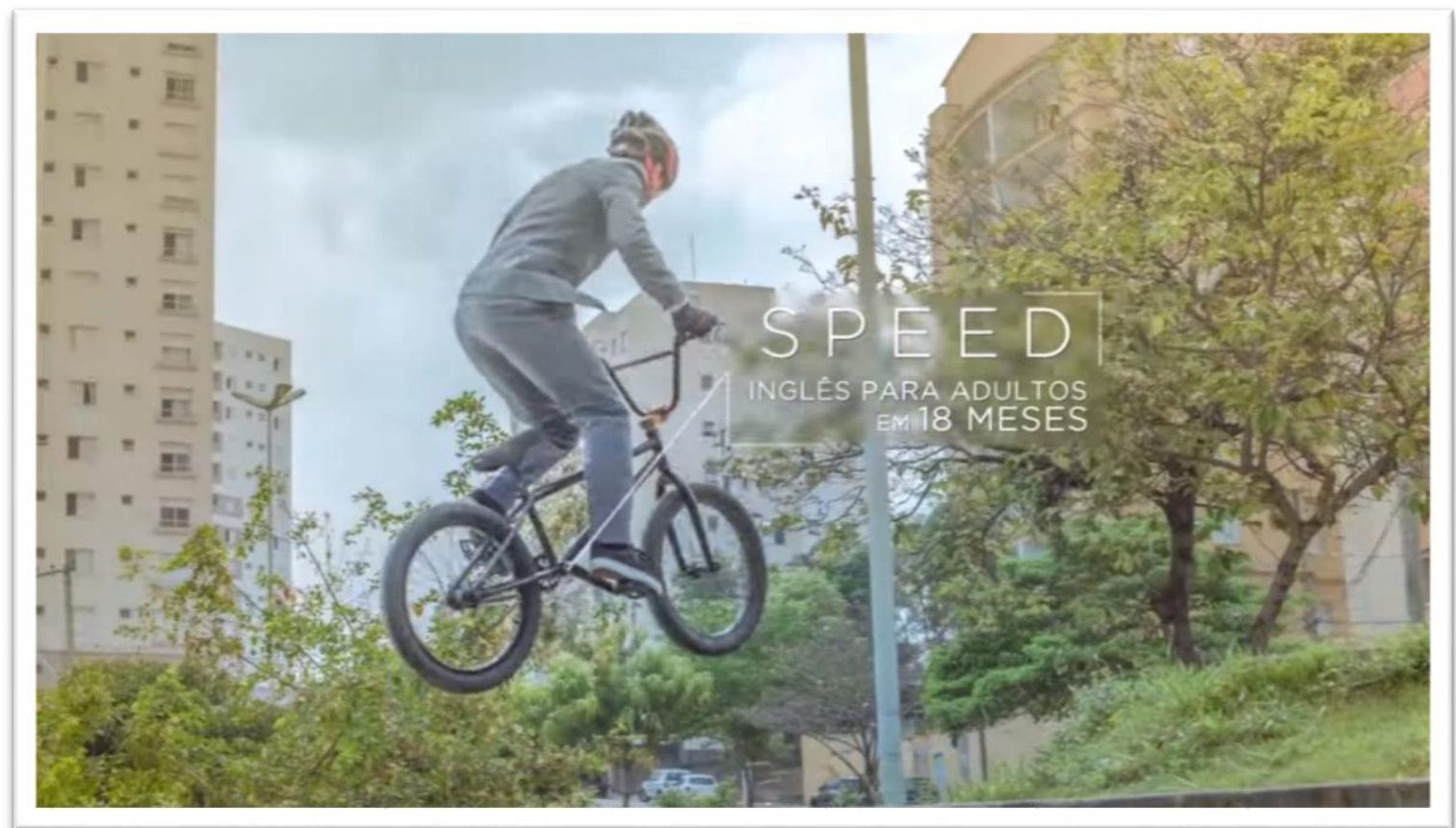

Esse vídeo publicitário atribui ou leva a jovialidade adolescente para o adulto. Em uma das cenas, um homem faz uma manobra radical (um salto com um giro no ar) montado em uma bicicleta, porém usando roupas bastante formais. Além das roupas formais, o texto verbal próximo ao centro da cena diz "speed, inglês para adultos em 18 meses". O imediatismo associado às gerações a partir da emergência da internet ganha primeiro plano e se explicita no texto pela velocidade imprimida na manobra, na palavra "speed" e na promessa de inglês em 18 meses. Esse imediatismo não é fundamentalmente diferente do que está implícito na noção de sincronicidade que descrevemos ao refletir sobre os conceitos de interação. Produtos que respondem imediatamente são mais interativos; são melhores. Se levarmos em conta os efeitos do apregoado discurso de que aprendemos pela interação, por um prisma imediatista 
e acrítico, aprender em 18 meses (mais rápido) é aprender interagindo mais em menos tempo. Ou seja, tratam-se de aulas mais eficientes.

As ideias pedagógicas norteadas pelo neoprodutivismo e que contribuem para o desenvolvimento da lógica da educação corporativa, de certa forma, descreditam o saber científico ao oferecer soluções encantadoras e ilusórias, inclusive pela ênfase nas relações e atividades prazerosas e pelo escamoteamento do esforço, do trabalho e da dificuldade. Em um nível, trata-se do anúncio de um serviço: aulas de inglês. Em outro nível, aqui predominante, trata-se do anúncio de um produto: o falante de inglês. Ou seja, o sujeito não consome propriamente um serviço, mas sim uma espécie de prótese identitária, nos termos de Dufour (2001, p. 05). Conforme argumenta Saviani (2010, p. 449), o utilitarismo e o imediatismo da cotidianidade prevalecem sobre o trabalho paciente e demorado de apropriação do patrimônio cultural da humanidade".

Figura 32: Vídeo D - Screenshot 3

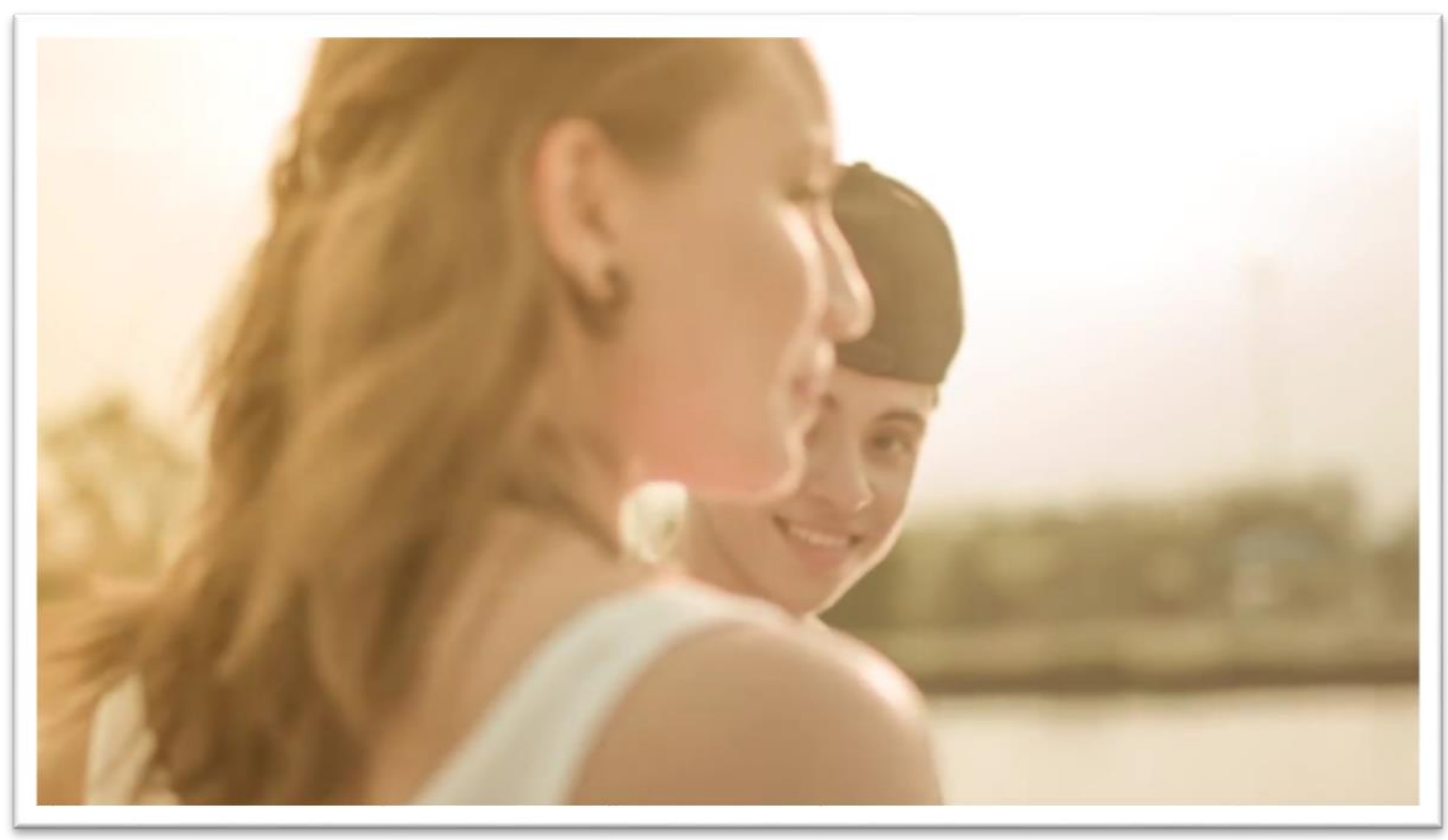

As cenas de jovens se divertindo em diversas atividades traduzem o "curtir cada momento", apoiando-se em uma memória discursiva que atravessa inclusive o discurso científico, que forma o conceito de interação em torno de certas características, como prazeroso, divertido, engajador, afetivo, dinâmico, flexível e promotor de opções e possibilidades. Os valores que o texto publicitário procura 
associar ao curso da instituição anunciante, em grande medida, coincidem com as características amplamente atribuídas da interação.

\section{Figura 33: Vídeo D - Screenshot 4}

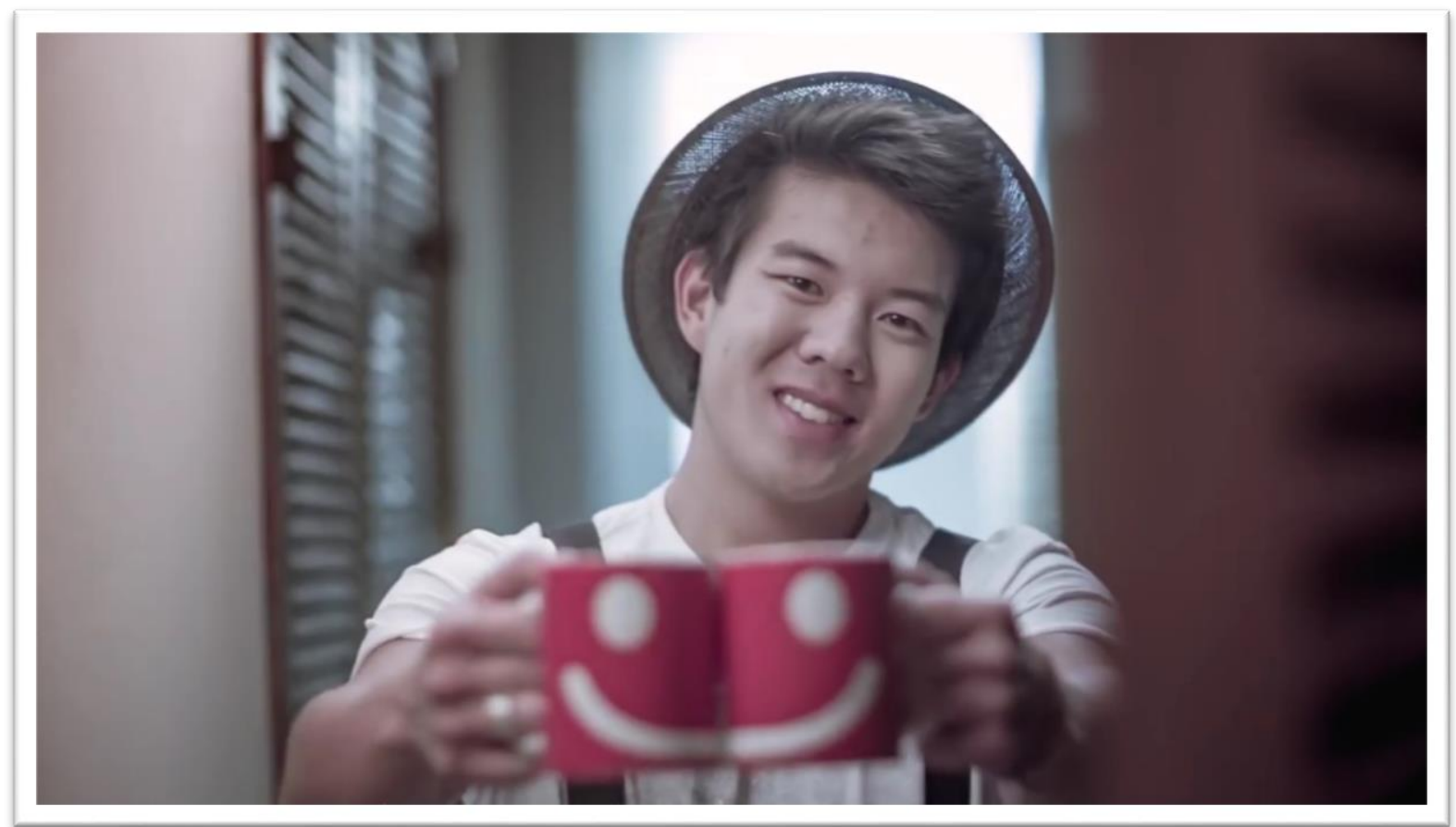

Figura 34: Vídeo D - Screenshot 5

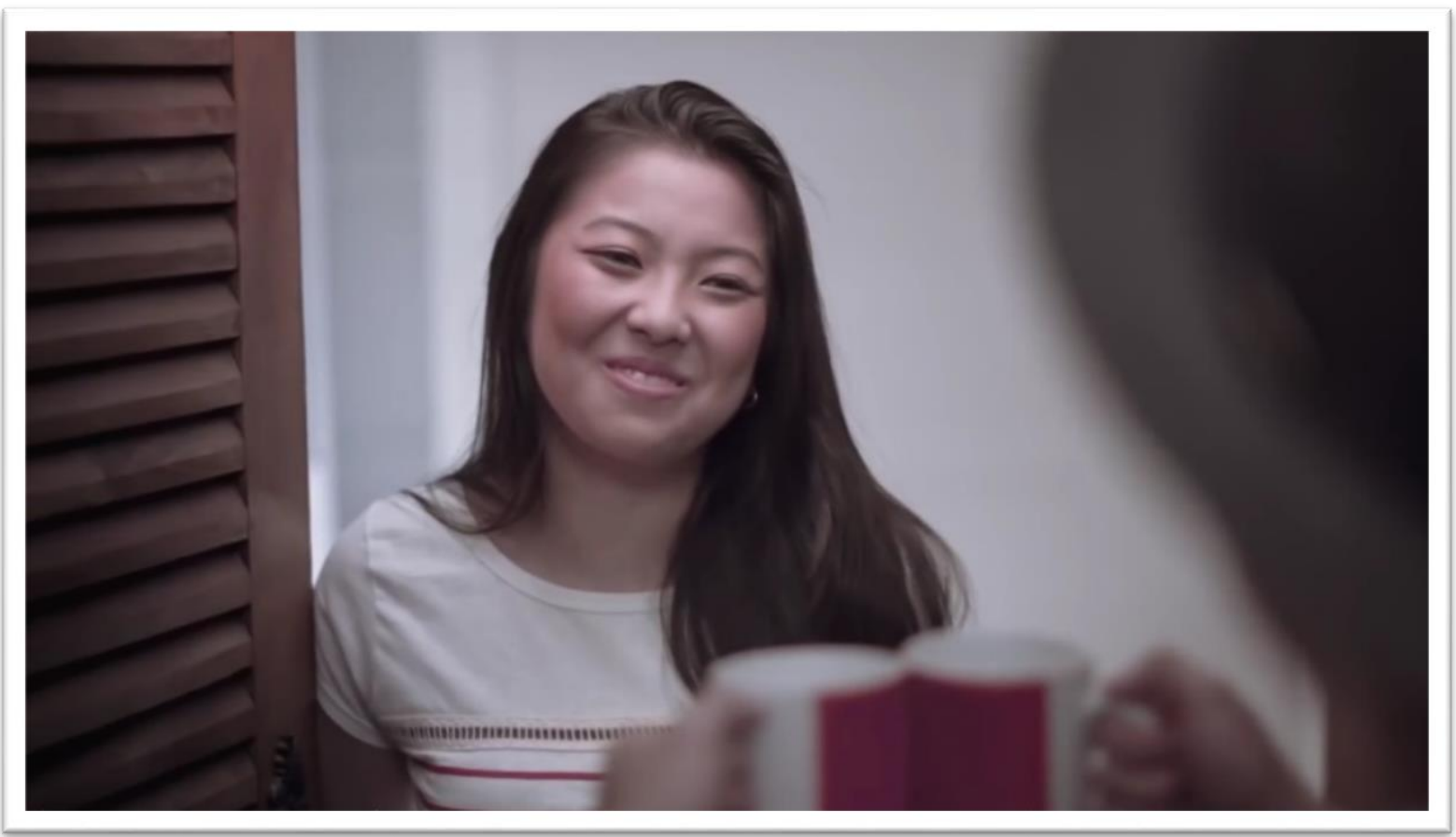


As diversas cenas de pessoas sorrindo, rindo e manifestando feições de alegria e felicidade contribuem para a expressão dos sentidos de prazer, diversão e engajamento, atravessados por elementos romântico-afetivos. Duas cenas, especificamente marcam esses elementos. Em uma delas, dois jovens andam de skate de mãos dadas por uma ponte deserta durante o pôr do sol. O primeiro ângulo de filmagem captura o pôr do sol recortando as silhuetas dos jovens, vistos de costas, passeando lentamente pela ponte de mãos dadas. Na mesma cena, há uma mudança de ângulo que então captura o rosto da jovem, suavemente desfocado, olhando para o horizonte com um semblante sereno e um sorriso apertado no rosto, e o rosto do jovem ao fundo, porém com o foco da câmera, admirando sua companhia com um sorriso mais aberto e expressão de alegria.

Em outra cena que marca os elementos romântico-afetivos, um jovem chega à porta de uma jovem com quem tem algum tipo de relação afetiva, provavelmente entre namorados, e oferece uma bebida servida em caneca a ela. Cada caneca tem os traços de um meio sorriso e um olho ilustrados e, para fazer a oferta, o jovem apresenta as canecas em justaposição, formando um sorriso em um rosto completo, com a ideia implicada de que uma caneca completa a outra e forma um todo coerente, assim como ele e ela. A jovem retribui com um sorriso e um semblante que expressa doçura e aprovação.

As cenas de jovens se divertindo em diversas atividades traduzem o "curtir cada momento", apoiando-se em uma memória discursiva que atravessa inclusive o discurso científico, que forma o conceito de interação em torno de certas características, como prazeroso, divertido, engajador, afetivo, dinâmico, flexível e promotor de opções e possibilidade.

Essa articulação das cenas coloca a ideia de engajamento no centro de um raciocínio circular. Envolver-se afetivamente é engajador, e engajar-se leva ao envolvimento afetivo; divertir-se é engajador, e engajar-se leva à diversão; sentir prazer é engajador, e engajar-se leva ao prazer; e assim por diante. Ao mesmo tempo, responde ao chamado da vida (a letra da música no vídeo diz "this is your life, this is your call') quem "curte cada momento". "Curtir" é o verbo do prazer sob essas condições discursivas, sendo o prazer a finalidade e a motivação de toda e qualquer atividade. Nesse sentido, "engajamento" e "prazer" coincidem e adicionam mais uma 
camada de circularidade na relação entre os elementos, o que, por sua vez, pode disfarçar a circularidade quando um dos elementos é omitido ou pode ser reduzido à máxima "prazer pelo prazer" ou "faço por prazer".

Figura 35: lógica circular entorno do engajamento pelo prazer

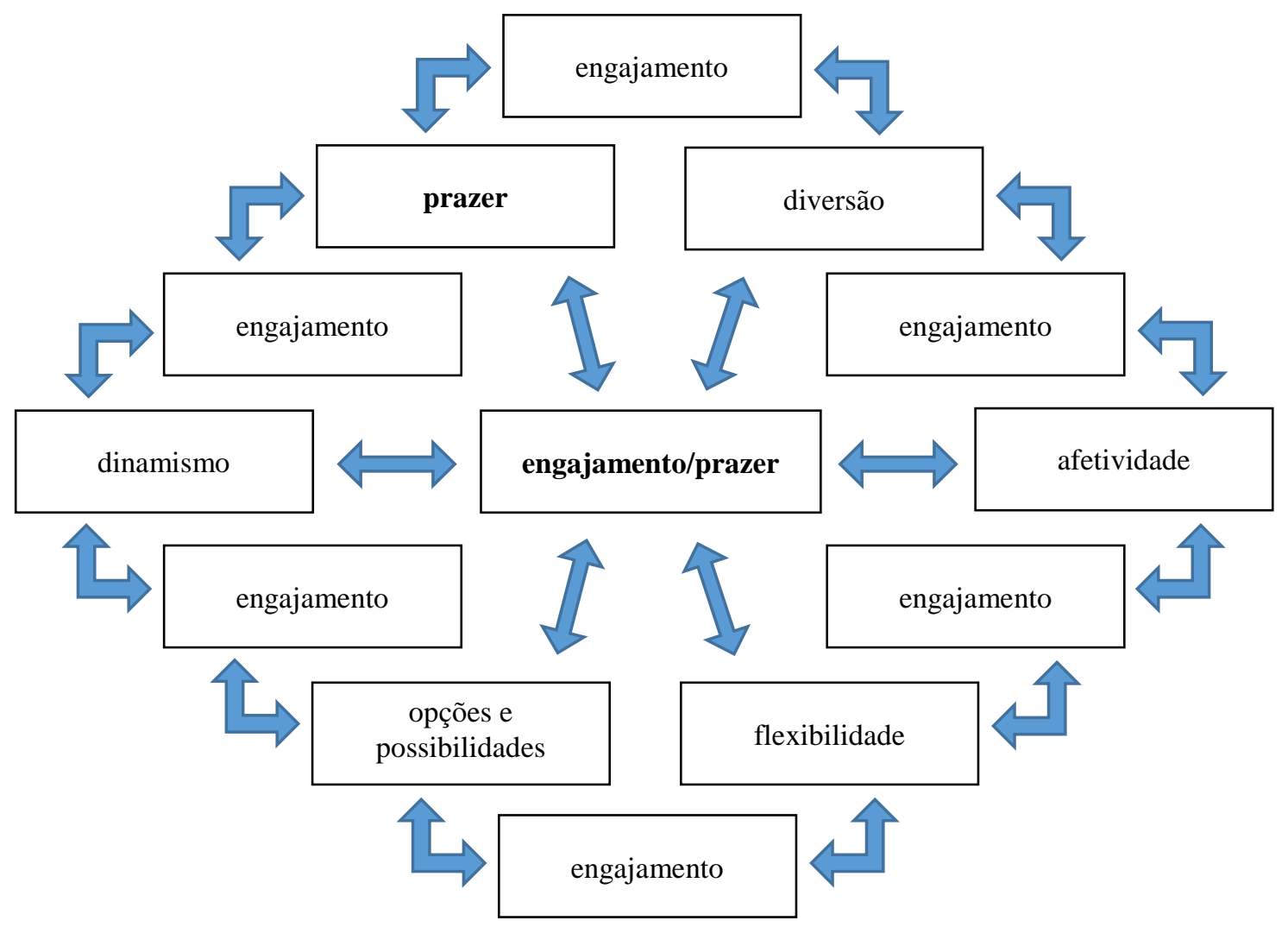

O indivíduo, buscando prazer (engajando-se ao chamado da vida), deseja falar inglês. Ele deseja falar inglês aproveitando cada momento (sentindo prazer a cada momento) com a finalidade de aproveitar cada momento por falar inglês (sentindo prazer a cada momento que o fato do indivíduo falar inglês pode proporcionar). O prazer é o que motiva o indivíduo a fazer qualquer coisa e, ao mesmo tempo, o indivíduo espera ter prazer em cada coisa que faz. Agora e sempre. Afinal, o que importa é "cada momento" e o prazer é o resultado imediato da ação. Nessa formação discursiva, a "obrigação", o "dever", "o "compromisso", a "seriedade", a "imposição" e a "espera" são renunciados ou até mesmo repudiados. São chatos; são antagônicos ao prazer. O indivíduo não deseja inglês para que o futuro seja dele; deseja o inglês por prazer. Além disso, o indivíduo não aprende pelo estudo ou pela dedicação, mas sim pelo prazer. Interagir é ter prazer. 
No vídeo, a interação também é associada à tecnologia digital mais enfaticamente em quatro cenas. Na primeira delas, uma jovem tira uma foto de si mesma (selfie) em diversas poses, usando seu telefone celular, sempre de forma alegre e descontraída, usando roupas despojadas, com uma paisagem ao fundo. $\mathrm{Na}$ segunda, um jovem também usa seu telefone celular, desta vez para navegar em uma rede social fictícia chamada Fiskagram, fazendo referência ao Instagram ${ }^{59}$, "curtindo" fotos de pessoas que também estão "curtindo" cada momento em Londres, na Inglaterra. Nessas duas cenas, a tecnologia tem o papel de mediadora de interações, aproximar as pessoas separadas geograficamente e prover os recursos para que os indivíduos expandam as possibilidades de se fazerem presentes nas redes sociais, mostrando o quanto estão felizes a cada momento registrado.

\section{Figura 36: Vídeo D - Screenshot 6}

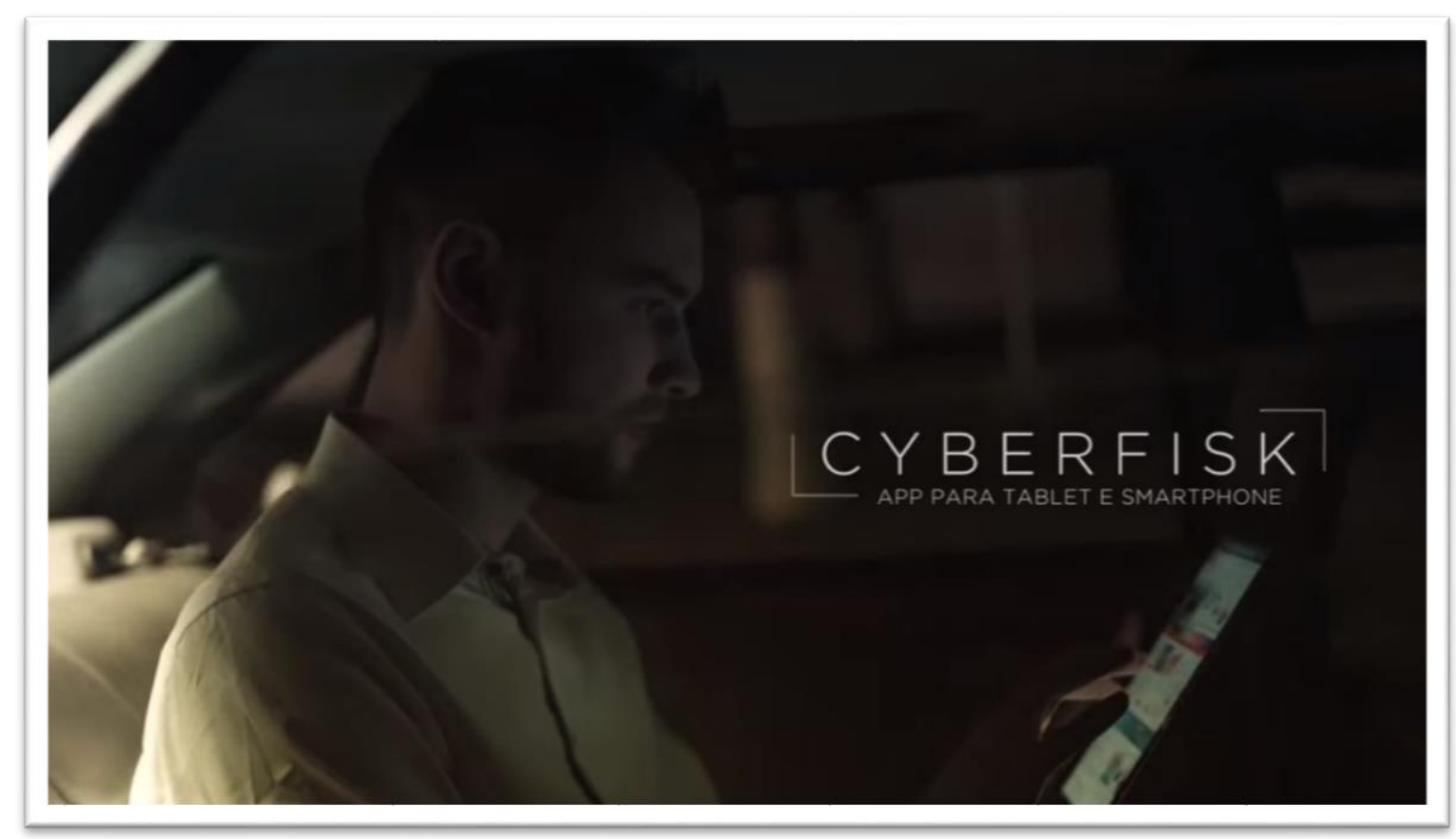

$\mathrm{Na}$ terceira dessas cenas, um jovem usa roupas formais e aparece entrando em um taxi com um tablet em suas mãos, na única cena em que a pessoa não aparece sorrindo, representando o indivíduo ocupado que está saindo ou se dirigindo a um compromisso à noite. No centro da tela surge um texto verbal como espécie de

\footnotetext{
59 Instagram é uma rede social online na qual seus usuários podem compartilhar fotos e vídeos entre si, e que permite também compartilhá-los em uma variedade de outras redes sociais, como Facebook, Twitter, Tumblr e Flickr.
} 
legenda que explica o que está nas mãos do jovem, dizendo "Cyberfisk, app para tablet e smartphone". A legenda não explica para que serve o aplicativo (se contém jogos ou atividades, por exemplo), o que produz pelo menos um entre dois efeitos. $O$ primeiro deles é a representação da mobilidade que a tecnologia pode oferecer e que presumida como bastante valiosa para o estereótipo da pessoa de negócios que tem uma agenda cheia de compromissos e que precisa ou deseja ter acesso à conteúdo e poder executar suas atividades em qualquer lugar, mesmo dentro de um taxi, e a qualquer momento, mesmo à noite, fora da escola e entre compromissos. O segundo é a representação da tecnologia como algo que tem um valor inerente e que, assim, agrega valor ao curso de inglês ao qual é associada. Uma aula de inglês que tem a presença de tecnologias, como aplicativos, aparece como sendo necessariamente melhor. Nessa construção metonímica, o aplicativo apresentado no vídeo é a consubstanciação da mobilidade, que é um dos valores centrais da globalização e do neoliberalismo, associada como qualidade do curso anunciado. Em uma sociedade neoliberal e globalizada, a mobilidade é uma das condições mais desejadas, porque dela decorre a proeminente hierarquia social na qual os padrões econômicos, sociais e políticos têm mecanismos de funcionamento mais poderosos e com maior eficácia do capital quando deixam a esfera local e passam a agir globalmente, com capital virtual e, portanto, com plena capacidade e liberdade de ajustamento. Sob essas condições de produção de sentido, ter mais mobilidade é ter mais poder e ser mais eficaz. Não importa para que serve o aplicativo; se é para estudar ou para oferecer entretenimento em inglês. O que importa é que, ao contar com essa tecnologia, o curso de inglês anunciado oferece mobilidade para seus consumidores.

A quarta cena em que a interação é associada à tecnologia, um jovem vestido com roupas formais caminha carregando um tablet, dirigindo-se à uma mesa à qual outras pessoas estão sentadas, também vestidas formalmente. Ele senta-se a mesa, sorridente, e manipula recursos futuristas de realidade aumentada ao mesmo tempo em que, no centro da tela, lê-se "'QR code" e "lousa interativa". Assim como no caso da cena anterior, a presença da tecnologia nesses termos procura atribuir valor ao curso e ao sujeito que o consome. A diferença é que nesta cena a tecnologia não consubstancia o valor da mobilidade, mas sim o valor avanço ou da evolução. 


\section{Figura 37: Vídeo D - Screenshot 7}

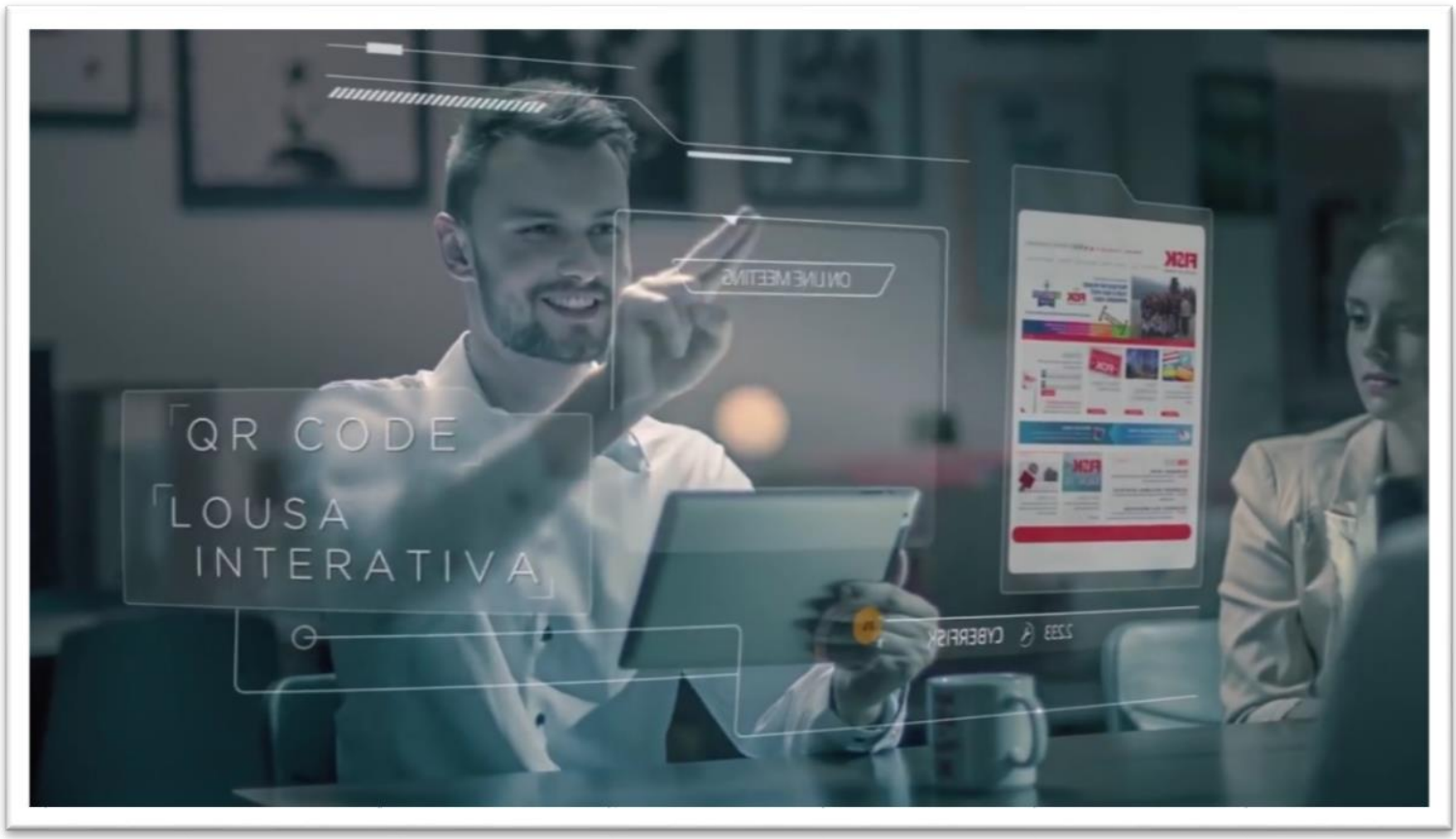

No modelo capitalista neoliberal, o ritmo de produção e consumo também se apoia em um discurso de obsolescência e evolução dos bens de consumo. Os produtos tecnológicos têm sua produção rapidamente descontinuadas e são substituídos por outros modelos com configurações adicionais ou características descritas como melhores de alguma forma. A oferta do novo produto necessariamente desqualifica o produto descontinuado e estabelece o "novo" como aquilo que há de melhor, de mais avançado.

A cena não procura explicar o que é um QR code, nem mostrar para que fim educacional ou instrucional ele é aplicado na aula de inglês, assim como não pretende demonstrar as utilidades didático-pedagógicas de uma lousa interativa e os possíveis benefícios para os alunos estudando o idioma em sala de aula. O QR code é uma tecnologia que tem mais de 15 anos e as chamadas lousas interativas são populares em escolas de idiomas e escolas regulares privadas há mais de 5 anos. Não são exemplos de "novas" tecnologias no sentido que o "novo" tem em uma sociedade líquida (BAUMAN, 1999). Mas essas tecnologias são apresentadas como tal ao serem associadas a recursos futuristas de realidade aumentada. Ao não explicar o que são essas tecnologias e associá-las a algo impressionantemente avançado tecnologicamente, o texto apresenta esses recursos como aquilo que há de melhor. 
Além disso, na lógica capitalista neoliberal, a tecnologia digital tem um papel fundamental para a eficácia e evolução de seus mecanismos, reforçando a ideia do "novo" como algo melhor. Segundo Saviani (2010, p. 429), esse modelo “apoia-se em tecnologia leve, de base microeletrônica flexível, e opera com trabalhadores polivalentes (...)". Nesse sentido, não é apenas a tecnologia que é nova. A presença dessas tecnologias na aula de inglês dessa instituição representa sua metodologia de forma igualmente avançada e promete a produção de um indivíduo mais capaz e competitivo. Em mais uma construção metonímica, o recurso tecnológico desenvolvido consubstancia uma forma de ensinar mais avançada, capaz de ensinar mais e melhor, formando indivíduos mais aptos a competir no mercado.

Além disso, outra particularidade relacionada à interação é especialmente marcada nessa quarta cena que envolve tecnologia. Diferente das primeiras duas, na quarta cena a tecnologia não exerce um papel de mediação entre indivíduos que interagem a distância ou presencialmente, mas ela própria é meio, objeto e fim da interação. O jovem se aproxima e senta à mesa sem cumprimentar as pessoas já à mesa, e também sem se dirigir a elas de nenhuma forma. Ele interage apenas com a tecnologia, enquanto os demais o observam. Conforme discutimos anteriormente, tanto no senso comum quanto no discurso científico, é amplamente apregoada a ideia de que determinadas tecnologias podem ser intrinsicamente interativas.

Ao refletir sobre diferentes conceitos de interação, evidenciamos que a condição interativa das tecnologias é dada, entre outros fatores, pelo número de opções proporcionadas para o indivíduo, pelo grau de controle que ele tem, e pela flexibilidade ou adaptabilidade, não só no sentido da tecnologia se adaptar a diferentes aplicações, mas principalmente no sentido dela se adaptar ao seu usuário. Trata-se de mais absoluta forma de individualismo: aquela em que o culto ao indivíduo o coloca, quase que paradoxalmente, em uma relação de alteridade consigo mesmo, criando, na constituição do sujeito, uma distância em relação aos outros e ao Outro que se reflete em uma distância de si em relação a si mesmo (DUFOUR: 2005).

A ideia de opções ilimitadas, de controle total e da flexibilidade (ou adaptabilidade) que leva à inflexão do sujeito para si mesmo também são marcadas na letra da música ao longo do vídeo em seu refrão: "what lies ahead you is an open road, (...) so take your chance, make your move and go, do it your way, because you're 
in controf". Em primeiro lugar, a metáfora da estrada aberta ("open road") constrói a imagem de um caminho sem obstáculos para o futuro, sendo que este não se constitui como um projeto de vida que deve ser galgado consistentemente passo a passo; no neoliberalismo, o futuro é como uma sequência de episódios, de "momentos", vividos um a um, sempre ao alcance do presente; sempre relacionada a decisão e a ação tomada "agora". De fato, "o futuro é de quem curte cada momento". A estrada aberta se apresenta como um conjunto de indeterminado número de momentos ou um potencial inesgotável de experiência que podem ser vividas ou "curtidas" a partir da decisão do sujeito, que precisa apenas aproveitar o que lhe é dado: "so take your chance, make your move and go".

Em segundo lugar, a questão da flexibilidade e do controle total são mais marcadas em "do it your way, because you're in control", com uma relação causal estabelecida pelo "because", sendo a flexibilidade expressa como derivada do controle. Conforme discutimos anteriormente, o grau máximo da flexibilidade no discurso neoliberal não é a multiplicidade de aplicações (capacidade de adaptação a diferentes situações e finalidades), mas sim ao potencial de adaptação ao indivíduo. Nesse sentido, a interação do indivíduo com o meio, ou até mesmo com outro indivíduo, resulta na adaptação do meio ao indivíduo, ou na adaptação do outro ao um. Em outras palavras, interagir é adaptar o meio e os outros a si. A relação causal entre controle e flexibilidade evidencia justamente essa inflexão do sujeito para si mesmo.

Por um lado, no espaço do não dito, "do it your way" contrasta com "do it my way", "do it their way", e "do it its way". Há assim um contraste entre a coerções que o sujeito exerce sobre si mesmo, as que os outros exercem sobre ele, e aquelas exercidas pelo Outro. Estar em controle isenta o sujeito de fazer algo sob as coerções (a) da autoridade do outro; (b) das convenções dos outros; (c) e de uma unidade coletiva. Estar em controle o coloca como senhor de si. O sujeito pode fazer o que quiser ("open road"), do jeito que quiser ("do it your way") porque é ele que está em controle ("because you're in coltrol"). O sujeito está em controle da vida; em controle de si mesmo. Conforme defende Dufour (2001: 4),

"no momento mesmo em que é atribuído a cada sujeito a tarefa de ser-si-mesmo, encontra-se a máxima dificuldade, senão a impossibilidade de sermos nós mesmos. (...) O sujeito pós- 
moderno não é apenas defasado, mas é dissociado. O sujeito pós-moderno encontra-se assim às voltas com a própria autofundação".

Ainda conforme Dufour (2001), diante de tudo que parece poder satisfazer as suas necessidades imediatas, o sujeito se torna presa fácil do mercado. Interagir é, enfim, estar em controle para fazer ou atuar do seu próprio jeito, constituindo a si mesmo a cada momento, sinalizando um "devir decadente do Outro no período pósmoderno" (DUFOUR, 2001: 5).

\section{Figura 38: Vídeo D - Screenshot 8}

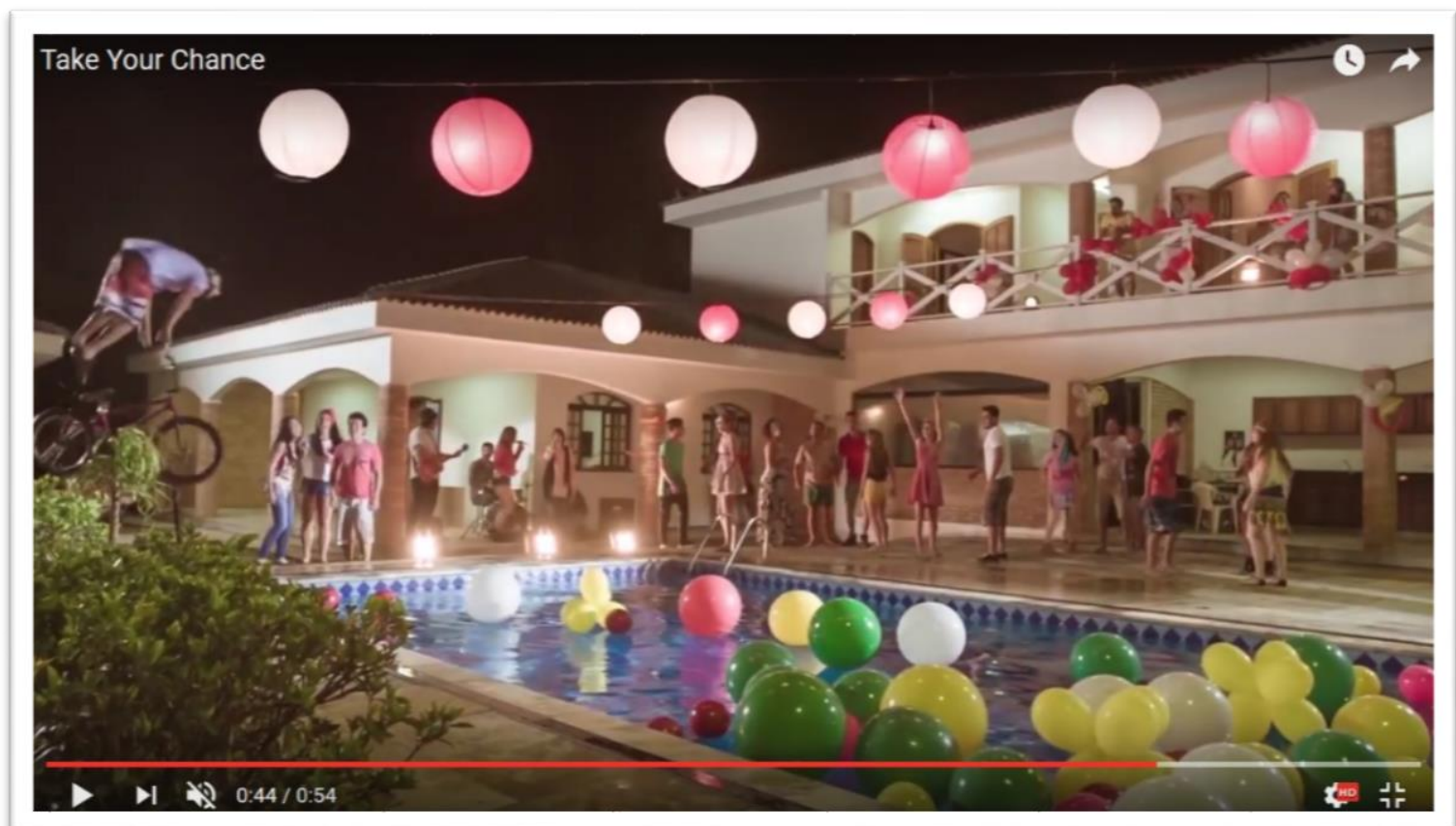

A cena final do vídeo publicitário, em alguma medida, concentra muitos dos elementos que exploramos em outras cenas. A cena mostra uma festa acontecendo à noite, na parte externa de um casarão, à beira de uma piscina. A cena é cortada por um homem que faz uma manobra radical em uma bicicleta, projetando-se no ar em direção à piscina. $O$ vídeo termina com o mergulho na água capturado por uma câmera filmando em " 1 a pessoa". Além da questão da jovialidade, da afetividade e da interação como entretenimento, essa cena expressa a continuidade ou perenidade do prazer e da felicidade. Ao longo do vídeo, entre as cenas mais longas, há algumas cenas rápidas de uma banda tocando a música que se ouve ao longo do vídeo. Há também uma cena em que um grupo de jovens dança em uma sala bastante grande. Na cena final, a banda aparece na festa, ainda tocando a música, e os jovens ainda 
estão dançando e aproveitando uma festa. A "curtição", ou seja, a interação prazerosa atravessa o dia e vai noite a dentro. Eis a síntese da chamada para que o consumidor "curta cada momento" o tempo todo. As características da interação, ou seja, a atividade prazerosa, divertida, engajadora, afetiva, dinâmica, flexível e promotora de opções e possibilidades coincidem com as representações da curtição de cada momento associada à marca que anuncia seu curso de inglês.

\section{Figura 39: Vídeo D - Screenshot 9}

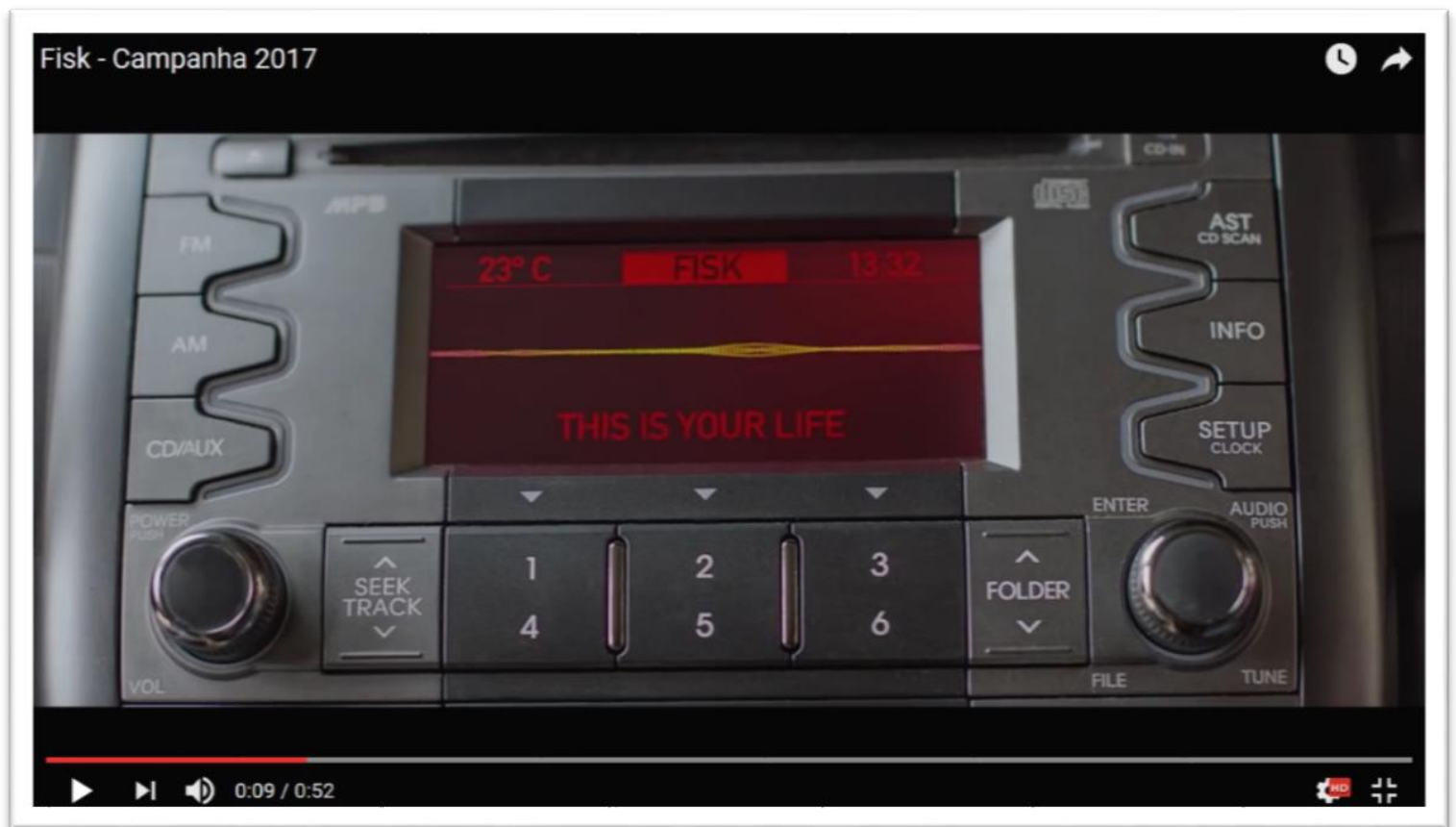

Na campanha do ano seguinte dessa instituição todos esses elementos estão presentes. O vídeo é muito parecido em sua superfície textual e também em sua organização discursiva, mas há uma diferença importante. Nele há um contraponto explícito aos elementos eufóricos (prazer, diversão, engajamento, etc.), que são a chatice, o marasmo, o desinteresse e a apatia. O vídeo mostra três cenas com essas notas. Na primeira, há um jovem sentado no sofá em um ambiente à meia luz, com o controle remoto em uma das mãos, trocando de canal em busca de algo que the desperte o interesse, e com um semblante de tédio. Na segunda, há três jovens deitadas em uma cama, cada uma com um celular nas mãos e parecendo estar navegando, todas com semblante de tédio. Na terceira cena, vê-se uma jovem dentro de um carro parado em um congestionamento que parece interminável, também com expressão de tédio. Seguem-se outras três cenas, como continuação das três 
situações descritas, nas quais as pessoas recebem um "chamado". Na primeira, a televisão sai do ar e exibe o texto "this is your life". A mesma mensagem aparece nas outras duas cenas, na tela do celular das jovens e no painel do rádio do carro, respectivamente. Nos três casos, as pessoas estão entediadas, quando recebem o chamado da vida ("This is your call, this is your life"). Desse ponto em diante o vídeo segue de maneira muito semelhante ao anterior que analisamos, inclusive com a mesma música tema.

Essa transição do enfadonho para o prazeroso também aparece nas campanhas de 2016 e 2017 de uma outra instituição, a mesma que analisamos com relação ao fluxo de ações, cujo vídeo apresentava a interação com um zumbi.

\section{Figura 40: Vídeo E - Screenshot 1}

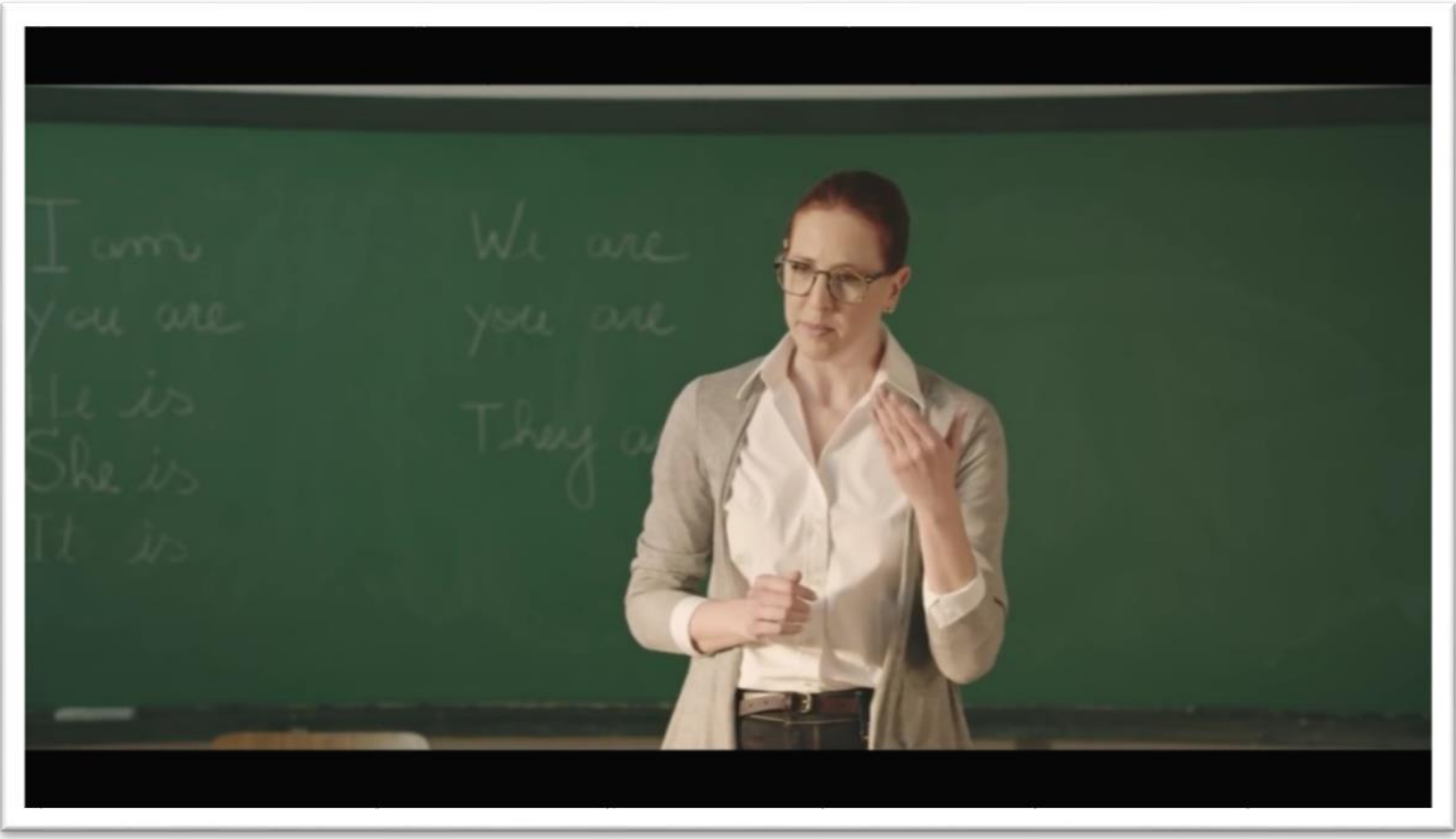

Na primeira cena desse vídeo, veiculado em 2017, há uma professora com alguns traços estereotípicos, como os óculos e a camisa branca, assim como o próprio fato de ser uma mulher e não um homem, ministrando uma aula de inglês. Desde o princípio há diversas marcas interdiscursivas que remetem a representações da escola regular. A primeira delas é a lousa (ou quadro negro, conforme é chamada mais tradicionalmente). Levando em conta que, há pelo menos 5 anos, o mercado de lousas interativas se consolidou tanto em escolas de idiomas quanto em escolas regulares privadas, os sentidos produzidos pela a imagem da lousa se apoiam sobre 
as representações da escola pública e todo o anacronismo tecnológico associado a ela. Na constituição dessa imagem, há também a conjugação do verbo to be escrita na lousa, produzindo sentidos que se apoiam no discurso do fracasso escolar. $\mathrm{Na}$ memória discursiva sob as condições de produção sobre as quais refletimos anteriormente, o verbo to be é como uma efígie de todos os dizeres sobre a ineficácia do ensino de inglês na escola regular, especialmente nas instituições públicas, remontando à ideia de fracasso escolar por um prisma de "processo-produto", no qual o aluno é ao mesmo tempo cliente e produto da instituição de ensino (SAVIANI, 2010), cujas causas são frequentemente atribuídas às condições dos alunos, mas principalmente às condições de trabalho nas escolas, ao material didáticopedagógico, ao sistema de ensino, e à desqualificação dos professores (CARMAGNANI, 2004).

Figura 41: Vídeo E - Screenshot 2

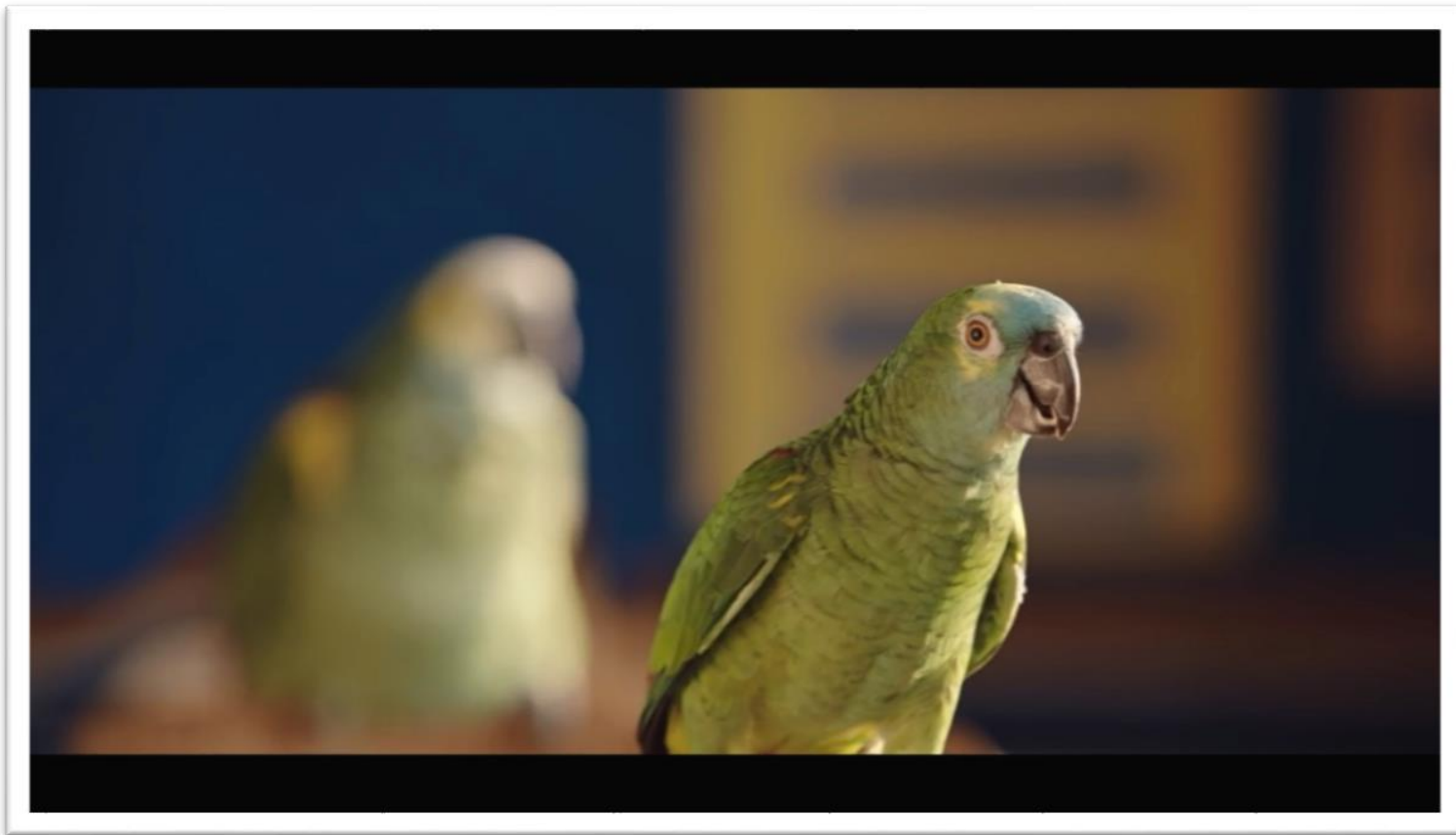

A primeira cena é uma caricatura da escola regular, inclusive mobilizando sentidos a partir de discursos sobre a ineficácia do ensino público. Como toda caricatura, trata-se de uma representação grotesca ou ridícula de sujeitos, situações e eventos em sala de aula, nesse caso com o objetivo de se prestar a escárnio e antítese da aula no curso anunciado. É preciso que seja uma caricatura, e que tal caricatura seja de sujeitos, situações e eventos em discursos sedimentados na 
memória discursiva de forma que, quando mobilizados, contribuam para a produção de um dizer "reconhecidamente" verdadeiro.

Ainda nessa esteira, e dando sequência à cena, a processa diz "repeat after me: I am". Os alunos repetem "I am", a professora prossegue com "you are", e os aluno repetem "you are". Nesse ponto a caricatura deixa de ser apenas grotesca e torna-se fundamentalmente jocosa, prestando-se ao ridículo, porque os alunos são representados como papagaios.

\section{Figura 42: Vídeo E - Screenshot 3}

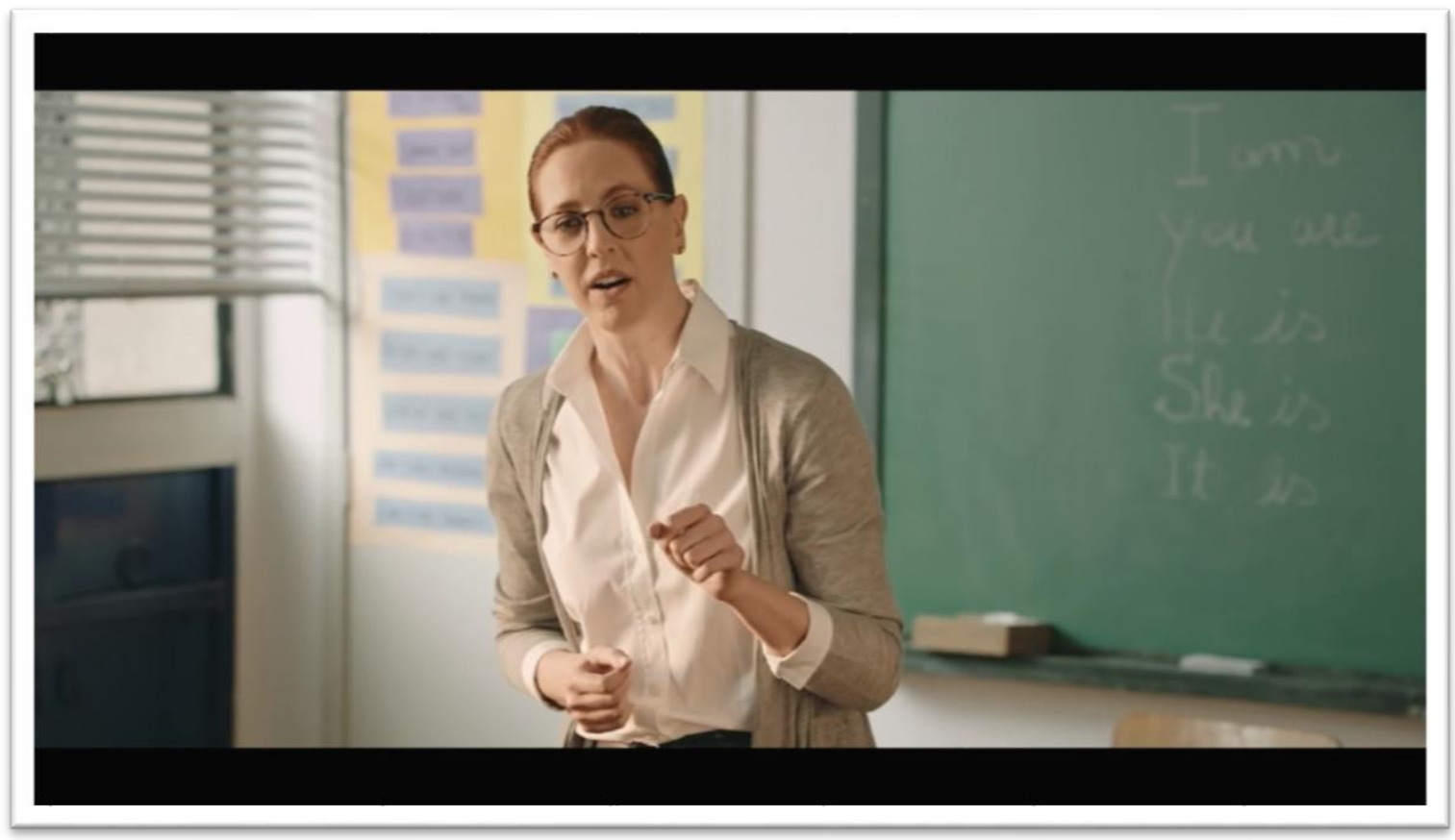

A representação dos alunos tem um efeito pejorativo sobre os alunos e a professora, mas sobretudo com relação às praticas da aula. A professora se mostra de fato empenhada em ensinar, inclusive esboçando um sorriso quando seus alunos conseguem repetir corretamente o que ela pede. Ela é alta, magra e de beleza estereotípica eurocêntrica, e vestida simples, porém elegantemente. Os óculos a "conferem" a inteligência e o domínio do conhecimento que se espera de um professor. Ou seja, essa a professora é como os professores são; é falada como os professores e não está aí o elemento chistoso. 
Os alunos como papagaios enfatizam a instrução "repeat after me". Essa instrução estabelece o padrão de interação que transforma alunos humanos em papagaios. Os alunos repetem como papagaios porque essa é a instrução, e é assim que eles devem interagir. Assim, apesar da figura do aluno ser aquela que é a mais calcada e escrachada, não é nela que se concentra o chiste, e sim na interação de padrão repetitivo, chato e monótono.

\section{Figura 43: Vídeo E - Screenshot 4}

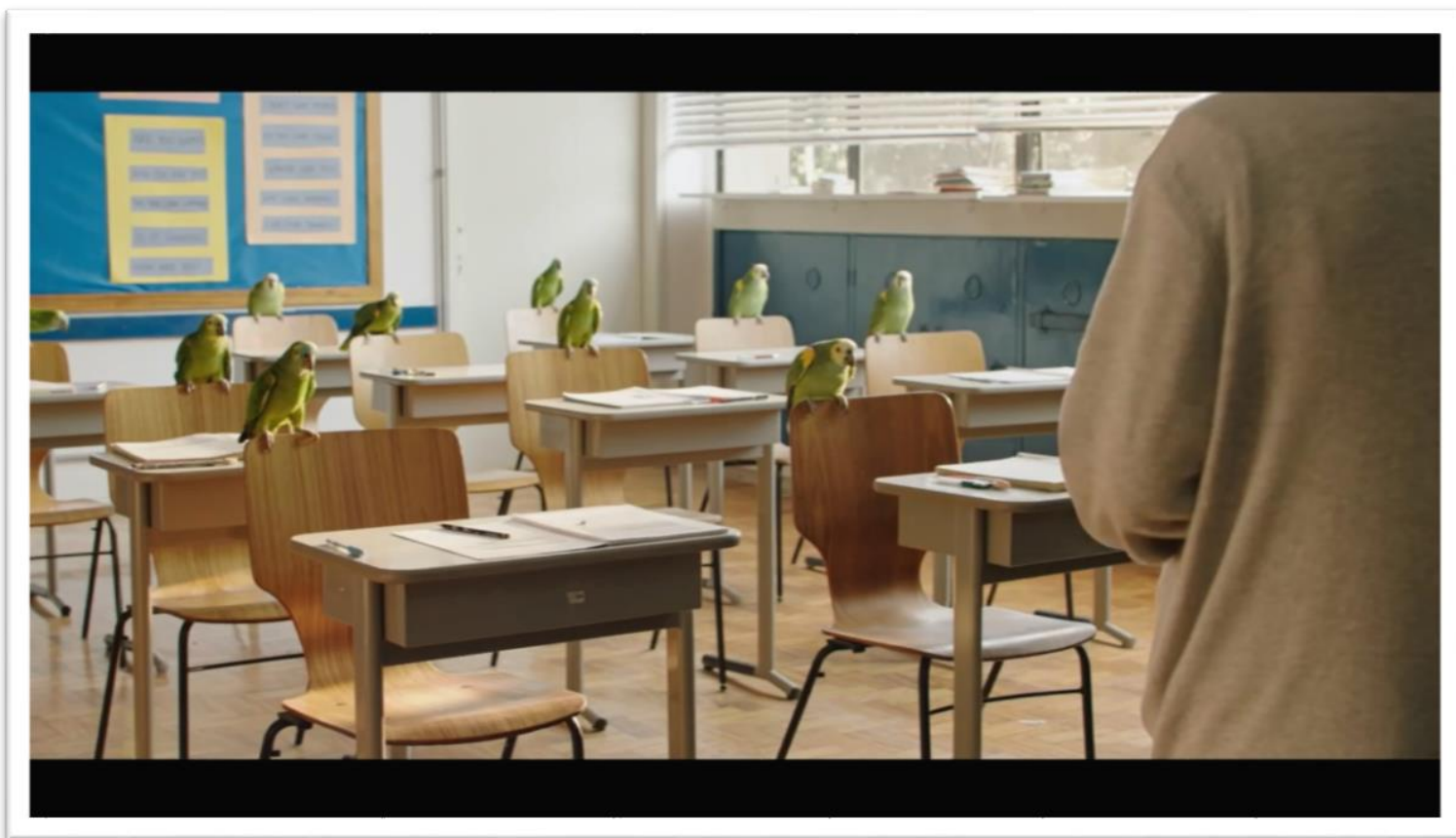

Esse padrão de interação, com essas características, continua a ser aproximado das práticas amplamente associadas àquelas da escola regular. Os alunos não estão em um ambiente que possa ser reconhecido como o de uma escola de idiomas. Ao contrário. Estão em uma sala ampla e mobiliada com cadeiras e mesas do tipo carteira, distribuídas em grade de fileiras, remetendo à disposição típica da escola regular. A mobília, a estrutura da sala e os materiais escolares estão em perfeito estado, e a sala não está superlotada, expressando que alunos e professores têm boas condições de trabalho. Toda a chatice e monotonia se concentram no padrão de interação estabelecido pelo "repeat after me". 


\section{Figura 44: Vídeo E - Screenshot 5}

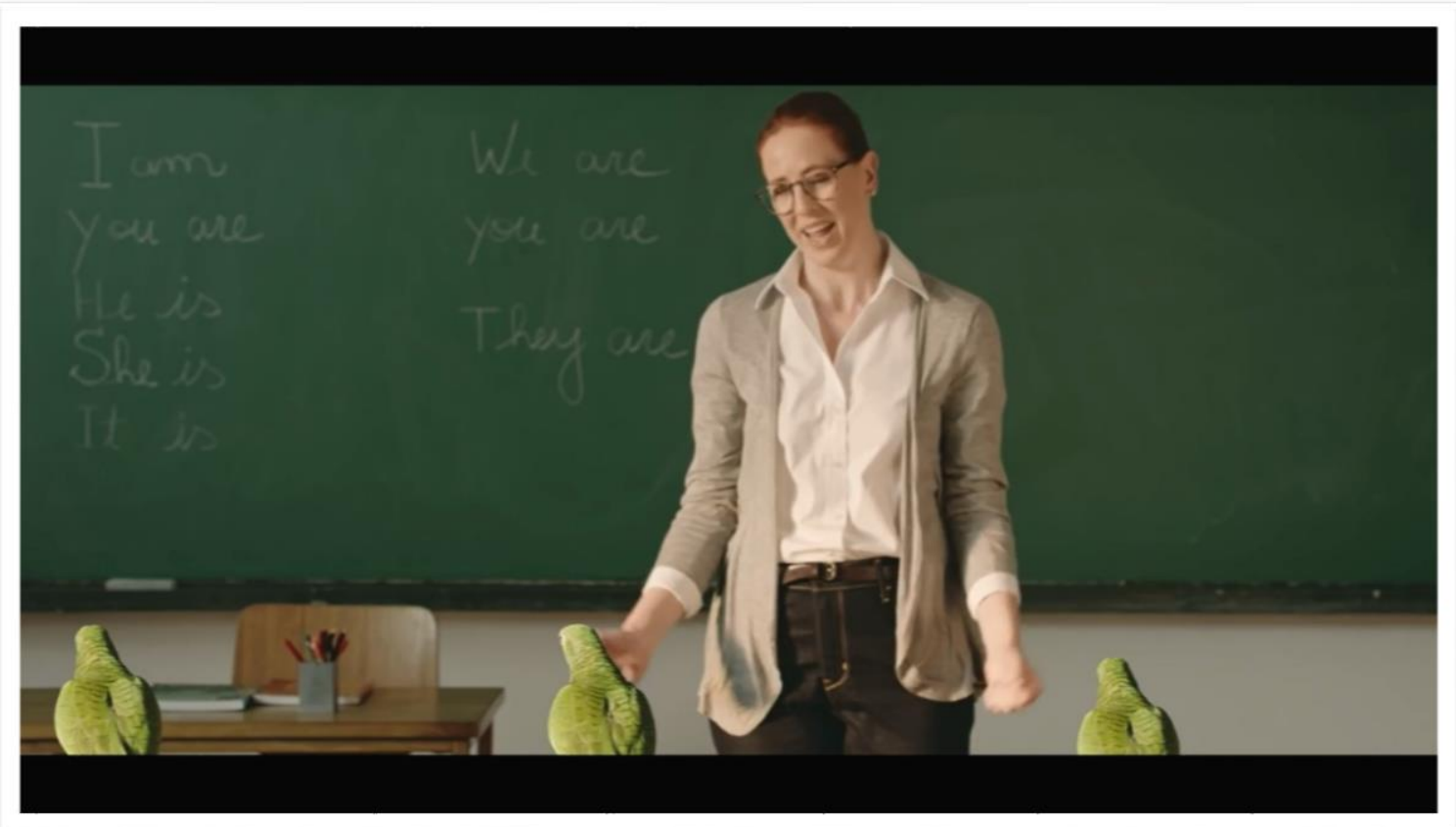

Conforme discutimos anteriormente ao refletir sobre o conceito de interação, os fluxos de ação não engajadores, divertidos, flexíveis e que não promovam colaboração, negociação e opções de escolha são menos eficazes (conceitos taxonômicos em um continuum) ou sequer são considerados interação (conceitos "essencialistas"). No vídeo, a interação repetitiva também é ineficaz e se expressa em piada e nas expressões da professora. Depois que os alunos repetem "I am" e "you are", a professora profere o comando "again". Ao invés de reiniciar o ciclo e repetirem "I am" e "you are", os alunos repetem "again". A professora reage com decepção e diz "não", e os alunos repetem "não" em coro e também descoordenadamente. Então a professora, já demonstrando grande impaciência em sua expressão facial e tom de voz, faz mais uma tentativa de conseguir retomar o rumo de sua aula com o comando "parem com isso". Os alunos descoordenadamente repetem "parem com isso". A cena termina com a professora em uma extrema expressão de decepção, irritação e impotência. Além da contração da boca e do rosto, a professora cruza o braço direito e leva a mão esquerda até a testa, apoiando a cabeça em desapontamento, enquanto os alunos continuam repetindo as frases da aula aleatoriamente. Com essa imagem, a professora se rende ao insucesso de suas investidas e ao fracasso de sua aula. 


\section{Figura 45: Vídeo E - Screenshot 6}

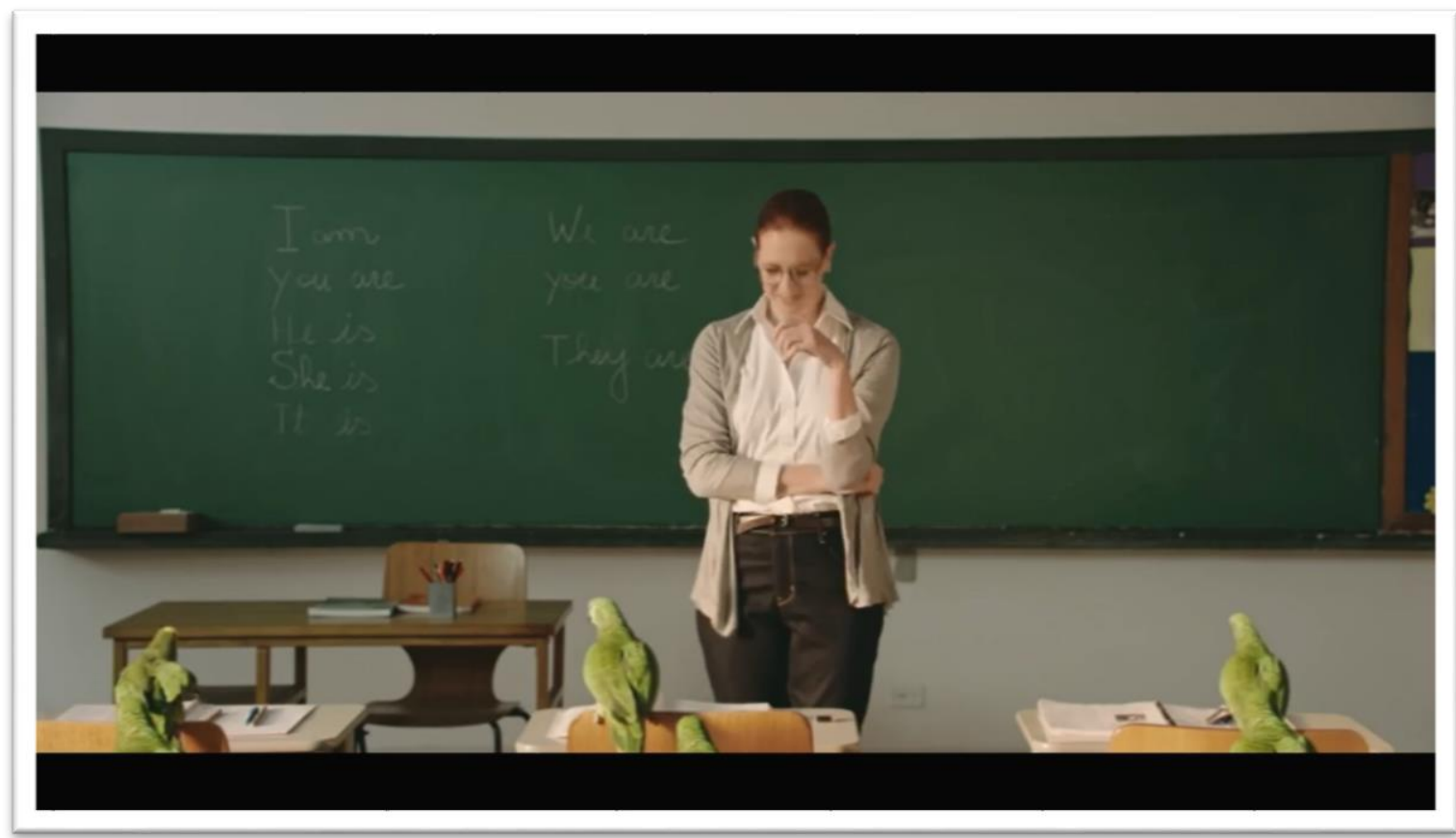

Na sua primeira metade, o vídeo publicitário encena uma piada baseada em uma brincadeira juvenil: repetir tudo e qualquer coisa que seu interlocutor fale visando a levá-lo à irritação. Isso também se constitui como um elemento de identificação que se apresenta ao consumidor que já teve ou que já presenciou essa experiência. Em certo sentido, o papagaio zomba da professora e a coloca na posição de vítima da piada.

Ao mesmo tempo, a representação do aluno como papagaio também é uma zombaria. Além do aspecto animalesco que em si já pode ser considerada uma diminuição da condição humana, o aluno como papagaio se mostra incapaz de compreender comandos e cumprir tarefas simples, desqualificado até mesmo para reproduzir trechos simples de texto em inglês. Diante dessa constatação e no auge da piada, o vídeo exibe mais um comando: "don't be loro". Com esse comando no centro da tela, o narrador faz sua entrada dizendo que "inglês chato ninguém merece". 


\section{Figura 46: Vídeo E - Screenshot 7}

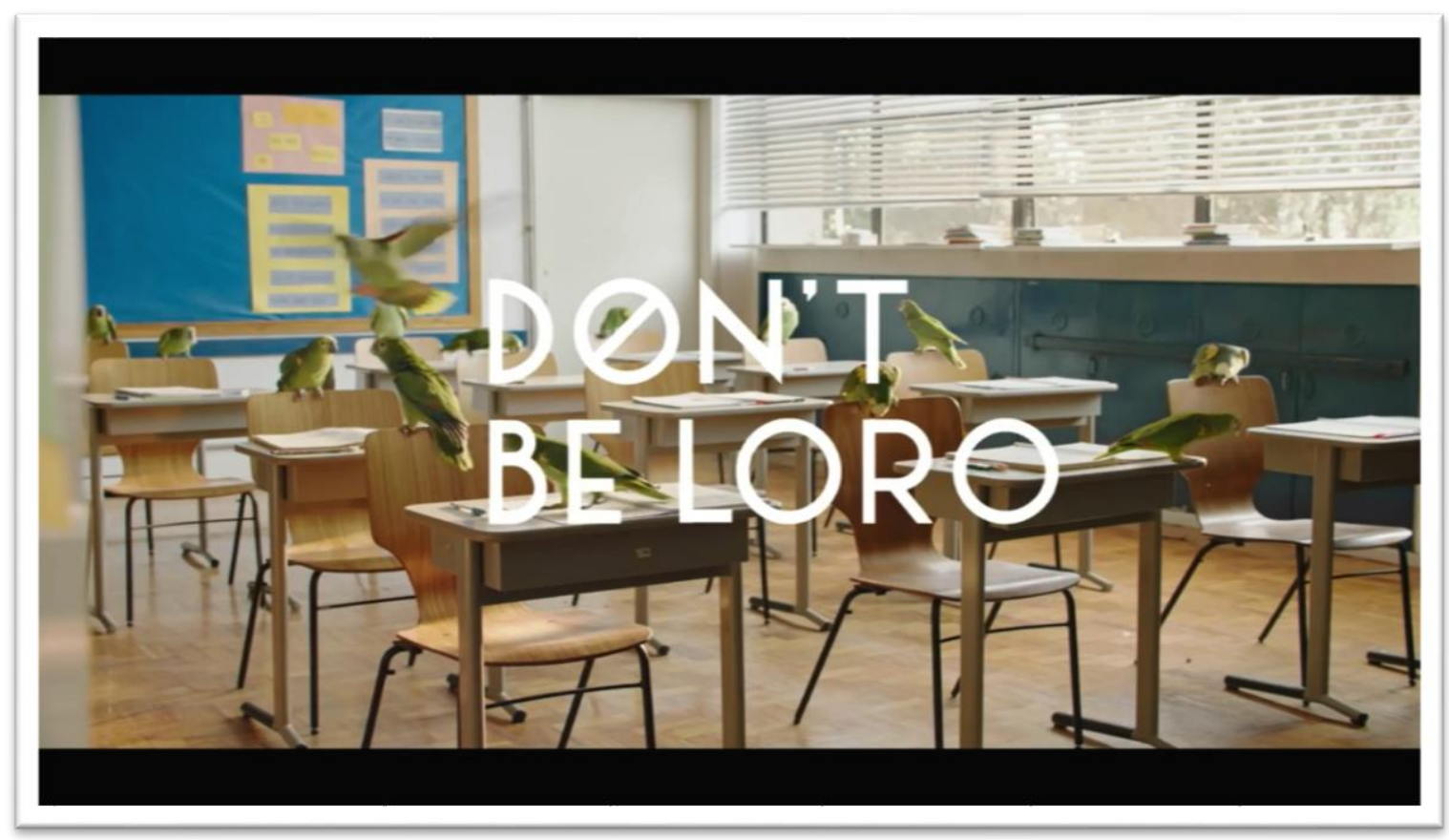

O enunciado do narrador resume todas as características da ineficaz aula representada na imagem da chatice e, ao mesmo tempo, isenta o aluno de qualquer responsabilidade por não ser capaz de falar inglês. Afinal, é o método e seus pressupostos padrões de interação repetitivos que produzem tal tipo de aluno: o papagaio que só sabe repetir, sem a menor ideia do que está dizendo e porque está falando. Eis outro elemento de identificação que o vídeo publicitário apresenta ao consumidor, especialmente àquele que já teve ou presenciou a experiência de fazer aula e não conseguir falar inglês. A culpa não é do aluno, e sim do método que não o "fez" aprender. "Ninguém merece" e ninguém aprende de fato com tamanha chatice. A interação apenas promove aprendizagem quando envolve o aluno e proporciona experiências mais dinâmicas e divertidas.

Apressadamente, poder-se-ia concluir que isso se apresenta como um argumento do texto publicitário. Ou seja, poder-se-ia concluir que o texto publicitário procura seduzir o consumidor levando-o a concordar que a aprendizagem não pode ser chata e repetitiva, e que deve ser dinâmica e divertida. No entanto, a análise mostra que todo o funcionamento discursivo de sedução do interlocutor-consumidor depende do prévio reconhecimento dos seus elementos supostamente argumentativos como verdadeiros como estratégia para chamar a atenção. 


\section{Figura 47: Vídeo E - Screenshot 8}

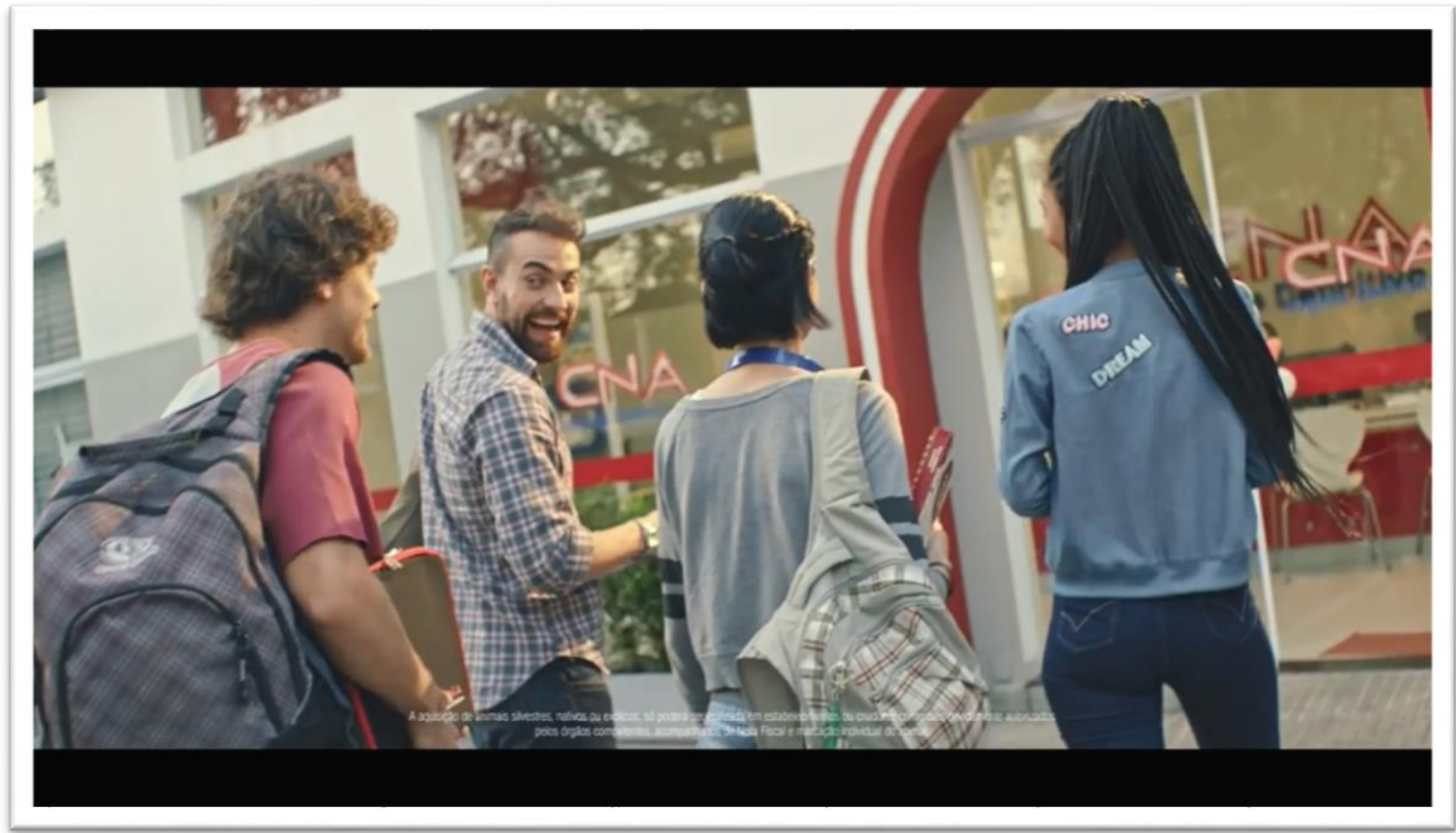

A piada que o vídeo publicitário encena apenas é possível porque, na memória discursiva:

- A escola regular é tida como ineficaz em suas práticas, inclusive educacionais, especialmente no caso do ensino de inglês;

- Práticas didáticas baseadas na reprodução de modelos fixos são amplamente consideradas insuficientes para promover adequadas oportunidades aprendizagem;

- É largamente apregoada, muitas vezes de forma "genérica" e sem o devido embasamento científico, que o sujeito aprende e se desenvolve pela interação; e porque

- O conceito de interação abarca características associadas à engajamento, dinamismo, fluxo de ações, entretenimento, variedade de opções, decisão do indivíduo, e flexibilidade.

Ao refletirmos sobre a ordem do discurso da mídia publicitária, sustentamos, entre outros pontos, que chamar a atenção e gerar interesse são objetivos diferentes que trabalham juntos na engrenagem sedutora desse discurso. Nesse vídeo em análise, a piada não tem o papel de convencer o interlocutor de que aprender inglês na escola regular é ineficiente e que uma metodologia baseada em interações 
repetitivas é chata e ineficiente. Ao invés disso, a piada procura chamar a atenção do interlocutor justamente lhe apresentando algo dramaticamente familiar (ou no mínimo reconhecível) e verdadeiro. É evidente que não há nada de engraçado em tentar aprender inglês e não conseguir. Mas, a piada se constitui justamente em caricaturar a situação e gerar certo distanciamento do sujeito-consumidor em relação ao sujeitoaprendiz. Esse distanciamento transforma o que poderia ser um drama em uma alegórica comédia.

\section{Figura 48: Vídeo E - Screenshot 9}

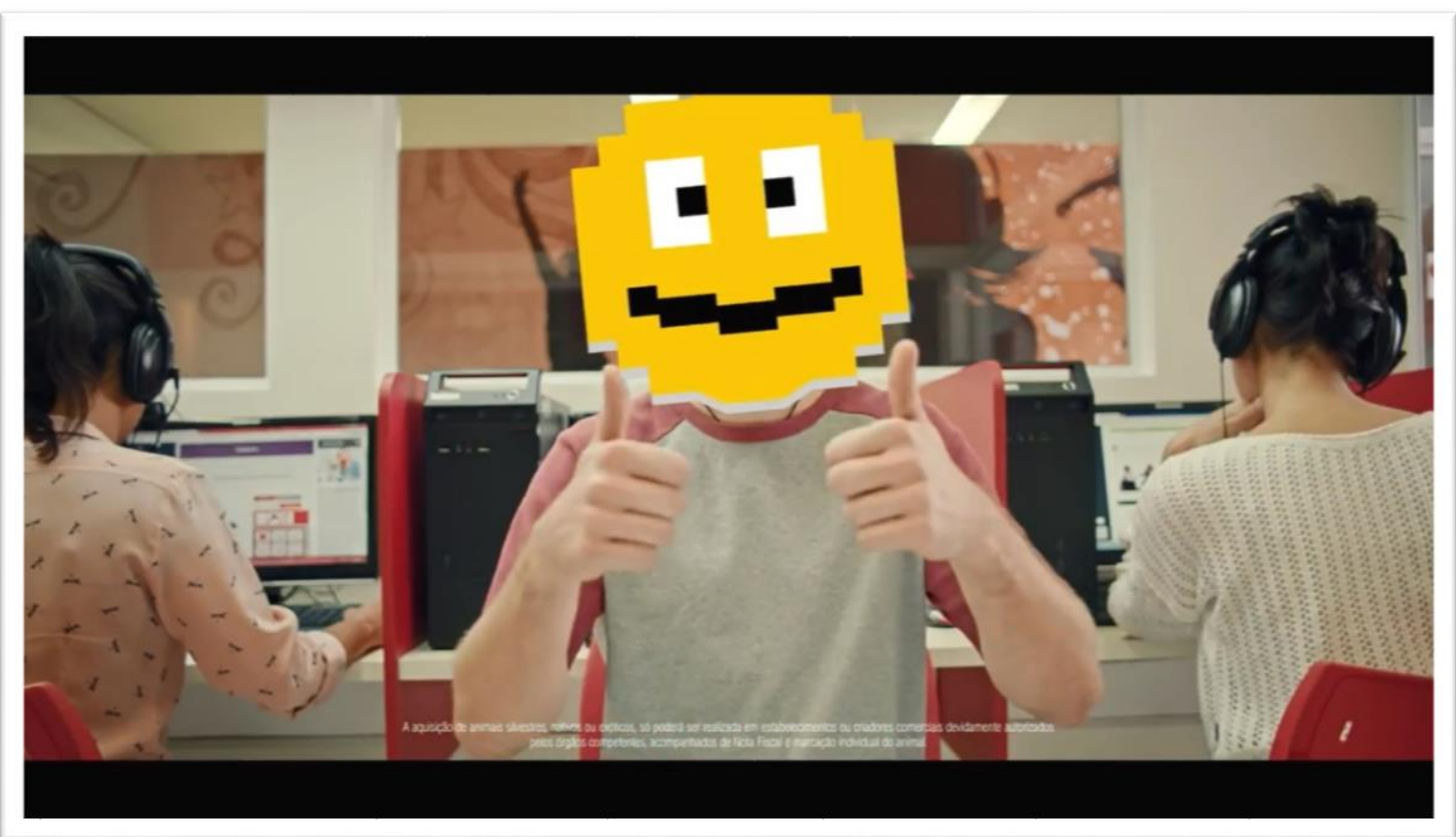

A sala de aula como lugar em que as pessoas são obrigadas a estar não é atrativa. Quase que ironicamente, a lógica neoliberal atribui à sala de aula a obrigação de ser atrativa. Nessa lógica, a escola deve levar o aluno a querer e gostar de estar em sala de aula. Os princípios neoliberais nutrem uma cultura de entretenimento e apelo à afetividade em várias instâncias do nosso modo de vida, inclusive na sala de aula. É justamente aí que encontramos a engrenagem argumentativa desse vídeo publicitário: ele pretende seduzir o consumidor sob o argumento de que o curso da instituição anunciante é exatamente como ele quer, ou seja, engajador, dinâmico, divertido, tecnológico e, consequentemente, eficaz. Essa argumentação tem início imediatamente após o narrador afirmar que "inglês chato ninguém merece". 


\section{Figura 49: Vídeo E - Screenshot 10}

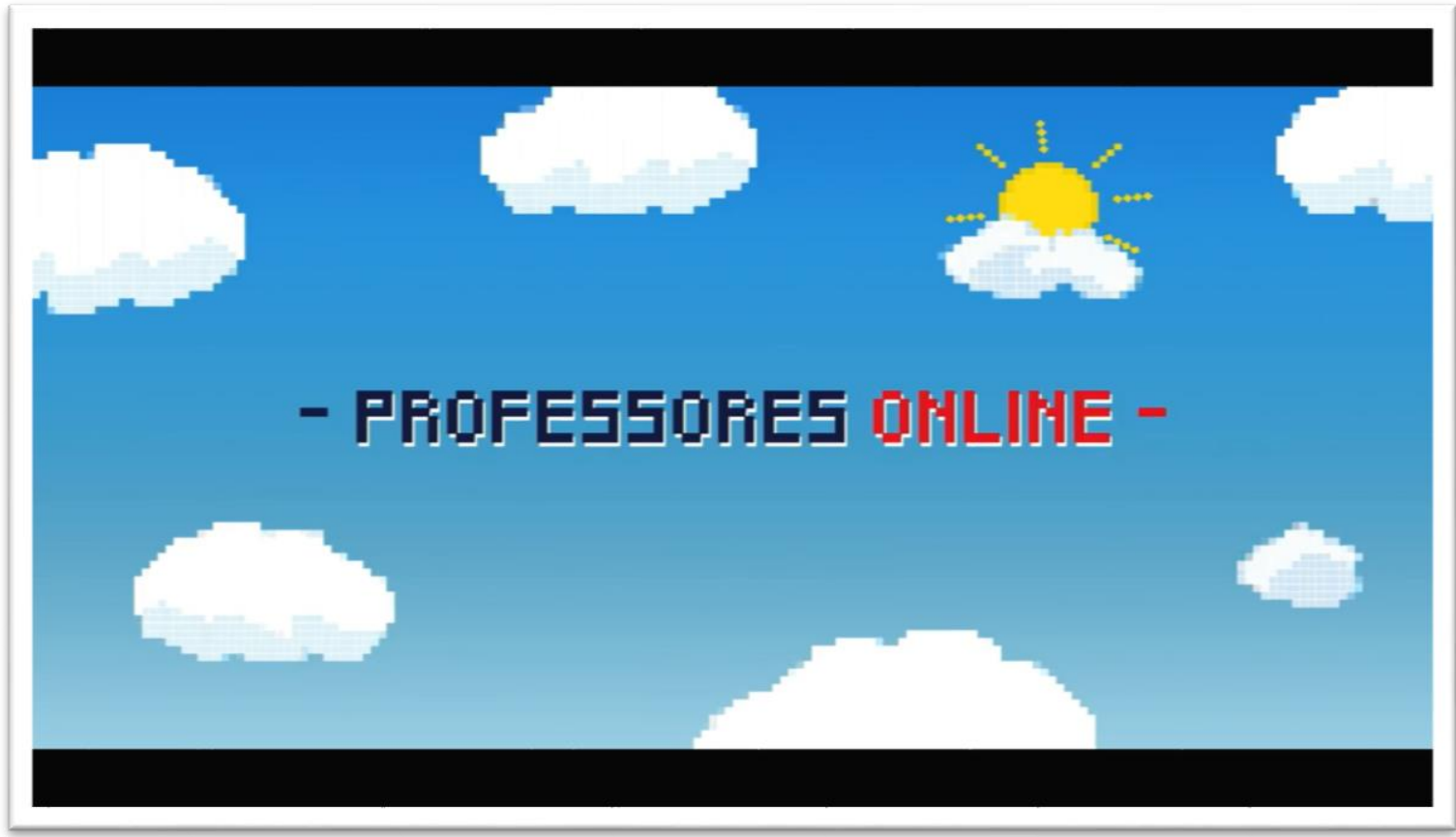

A parir daí seguem uma série de cenas que representam características do curso na escola anunciante, com uma música que remete a ideia de videogames. Diferente da música no vídeo que analisamos anteriormente, a qual estava em primeiro plano, era cantada e do gênero pop, essa é uma música eletrônica baseada em sintetizadores (ou ao menos se apresenta como tal), portanto sem voz, do gênero conhecido como vídeo game music, VGmusic, ou ainda chiptune.

$\mathrm{Na}$ primeira dessas cenas, um grupo de pessoas chega à escola, todos vestidos de forma bastante jovial, com seus materiais escolares em mãos ou com em suas mochilas, expressando alegria e prazer em estarem indo estudar e interagindo naquele lugar, principalmente quando um deles abre um largo sorriso de frente para a câmera. Essa primeira cena contrasta com os elementos chatos e enfadonhos da sala de aula da piada. Não é preciso afirmar que o ensino inglês nessa instituição é eficaz. Basta representar o ambiente como motivador, dinâmico e divertido para que a eficácia seja tácita. A expressão dos jovens associada à música de fundo tem um efeito "gamificador", produzindo o sentido de que estudar nessa instituição é tão motivador, dinâmico e divertido quanto jogar videogame.

O narrador do vídeo então anuncia que na instituição "você tem portal do aluno e professores online para tirar dúvidas e praticar seu inglês" (grifo nosso). A 
partir desse ponto, essa espécie de gamificação do curso de inglês da instituição se intensifica por meio de outros elementos, também em articulação com a música. 0 primeiro deles é a cena em que diversos alunos estão estudando nos computadores da escola, todos usando fone de ouvido. Os computadores são alinhados em uma parede de vidro, e a câmera avança da esquerda para a direita, em velocidade constante e no ritmo da música de fundo, simulando o mesmo tipo de evolução da tela em jogos de videogame considerados antigos e tradicionais, com imagens produzidas em segunda dimensão, isométricas ou de projeção oblíqua, em que o ponto de vista se "movimenta" dessa forma. O caráter "videogame" se reforça quando, nessa evolução da tela, um dos alunos repentinamente aparece voltado para a câmera e tem seu rosto sorridente substituído por uma caricatura digital amarela e também sorridente. Na cena seguinte, os professores online são anunciados pelo narrador e surge uma paisagem retratando um céu azul com nuvens brancas e um sol amarelo. No centro, lê-se "professores online". Tanto a paisagem quanto as letras aparecem também "pixelados".

Figura 50: Vídeo E - Screenshot 11

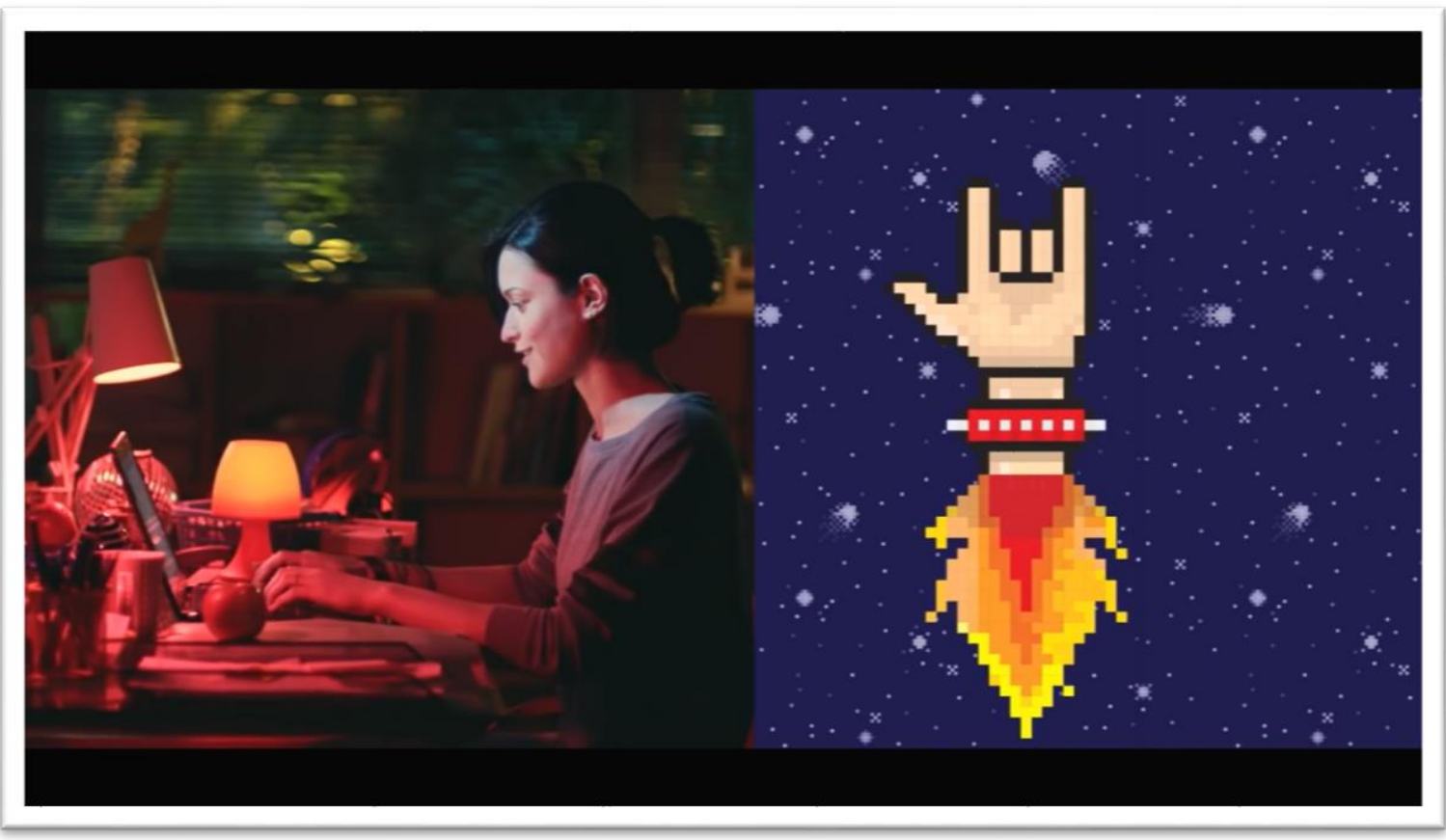

Os videogames de última geração têm imagens digitais tridimensionais, recursos de realidade aumentada e realidade virtual, sensores de movimento e qualidades gráficas de altíssima definição. Com relação ao som, os jogos são 
produzidos com trilhas sonoras comparáveis à qualidade cinematográfica. A tecnologia e o mercado dos jogos eletrônicos avançam e procuram, com cada vez mais sucesso, simular a "realidade" no sentido de promover uma experiência de "imersão" do sujeito. Ora, se os videogames procuram imitar a realidade, como representar um jogo sem que se corra o risco de que o interlocutor não note que se trata de um jogo?

Nesse vídeo publicitário, conforme dissemos, o gênero da música é VGmusic, ou ainda chiptune, ou seja, não é um gênero emergente. Ao contrário, seu estilo monofônico remete aos jogos de videogames de 8 a 16 bits, considerados clássicos ou, como são chamados hoje, vintage. A caricatura sobre o rosto do aluno também tem o mesmo estilo "clássico" de videogame, pela cor sólida, pelo desenho bidimensional, e pela imagem "pixelada" 60 .

\section{Figura 51: Vídeo F - Screenshot 1}

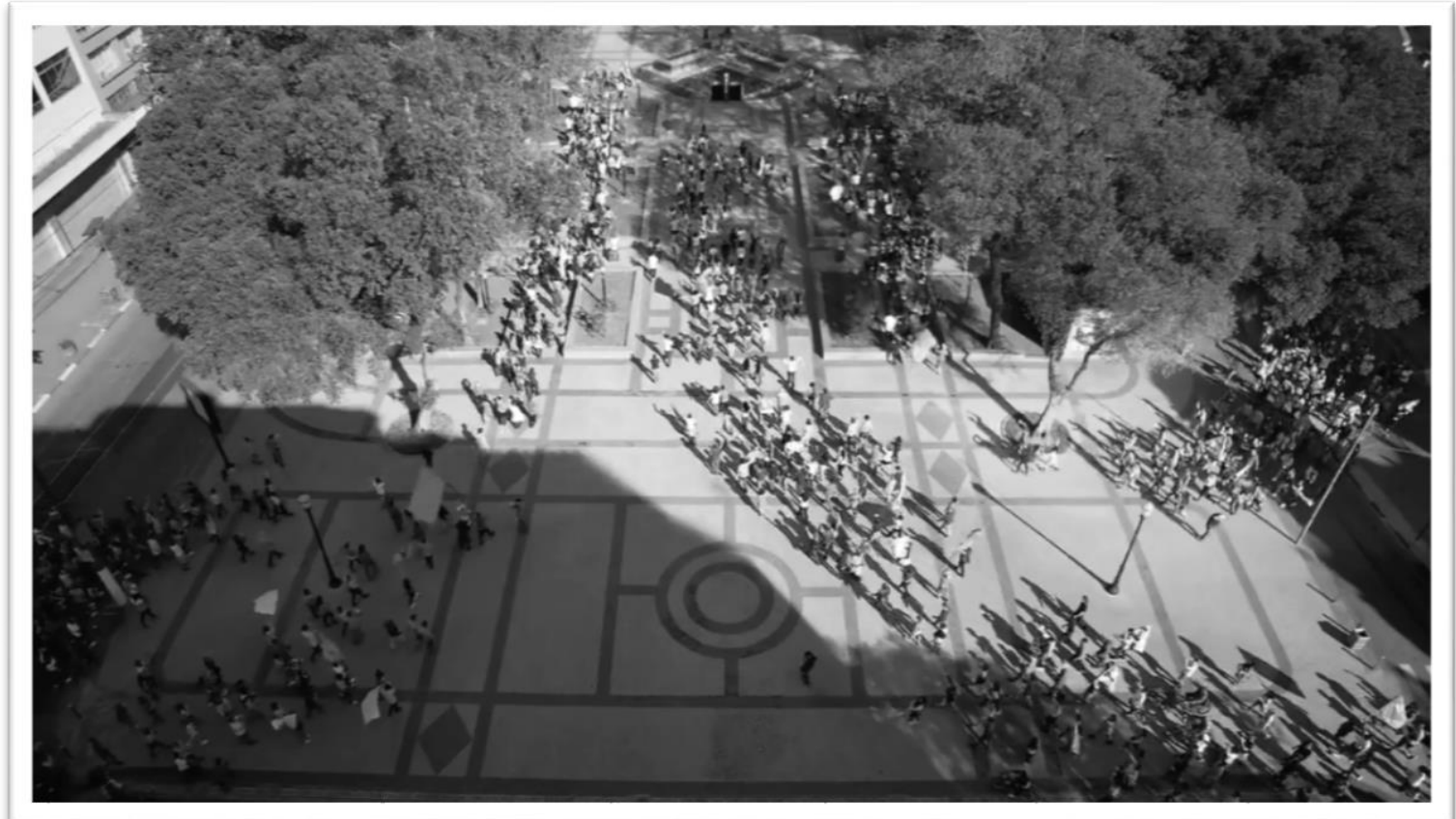

Assim eram as imagens e os sons dos jogos dos primeiros videogames que surgiram no mercado. A qualidade rudimentar desses jogos os separam mais

\footnotetext{
60 Pixel é a unidade mínima de um ponto que compõe uma imagem digital, sendo o número de pixels por polegada, por exemplo, uma medida da qualidade da definição de uma imagem. Quanto maior a quantidade de pixels, maior a qualidade da imagem. Uma imagem "pixelada" (do inglês pixelated) é aquela de baixa qualidade em termos de definição, ao ponto dos pixels poderem ser identificados individualmente.
} 
claramente da realidade, ao menos em relação ao som e à imagem. Além disso, são considerados clássicos, associados a personagens de jogos ainda entre os pais conhecidos, como Mario Bros, Alex Kid, e Sonic. Soma-se a isso a onda relativamente recente de exaltação desses videogames considerados clássicos, atribuindo-lhes grande valor, inclusive comercial ${ }^{61}$. Associar o ambiente e os recursos tecnológicos da instituição anunciante a esses jogos torna a gamificação mais facilmente reconhecível e seus efeitos mais eficazes.

\section{Figura 52: Vídeo F - Screenshot 2}

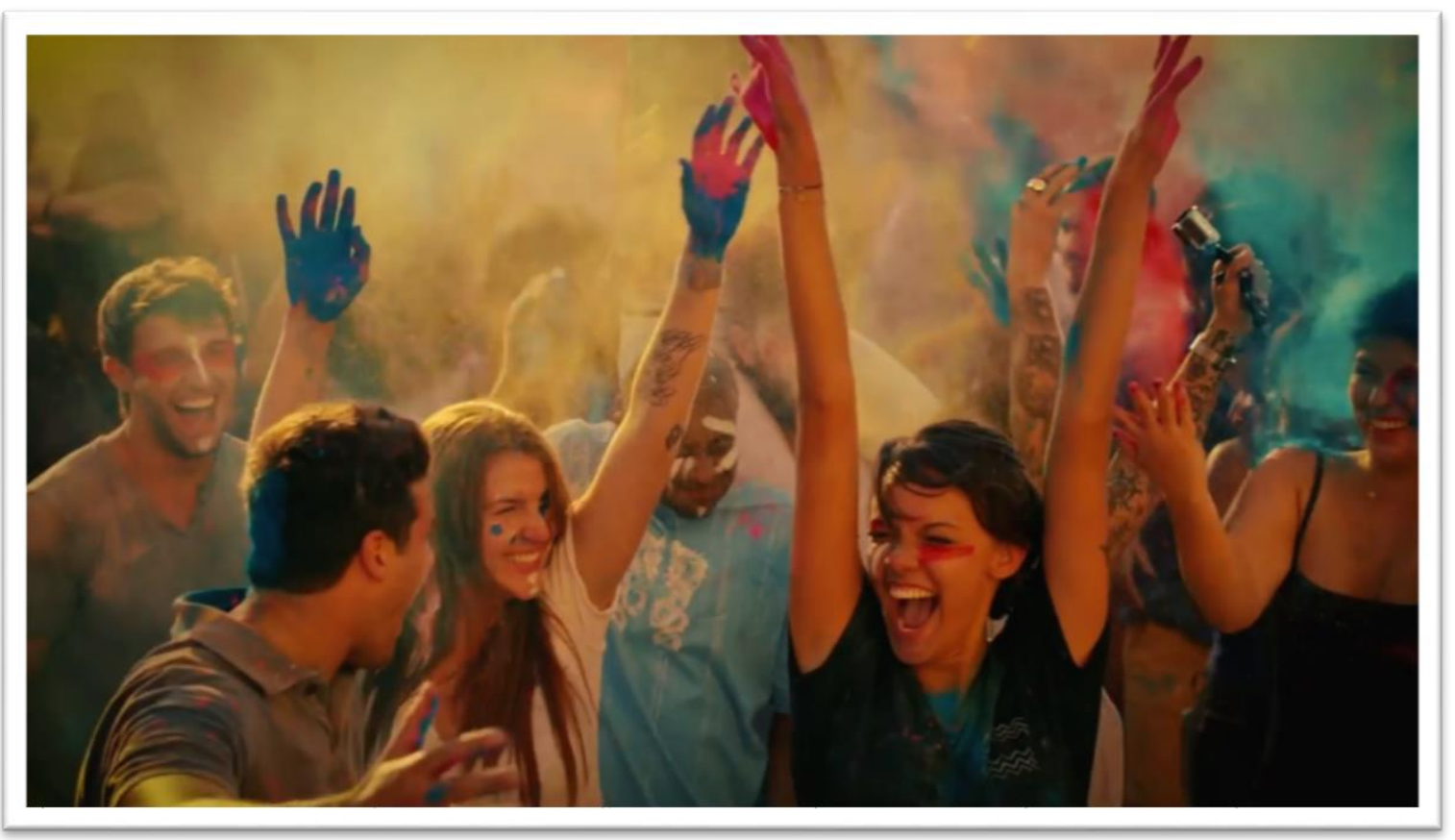

Essas construções de sentidos são ainda mais claramente expressas na última cena. Nela, uma mulher está sentada à uma mesa ou escrivaninha, usando o laptop para estudar inglês e acessar o serviço de professores online anunciado pelo narrador. A cena avança e o quadro se divide em dois, mantendo a mulher no quadro à esquerda. À direita, também com imagens de qualidade "pixeladas" e com a mesma música de fundo, vemos um foguete no formado de mão e pulso, fazendo um gesto que remete música de gênero Rock e Heavy Metal, viajando em direção às estrelas. Principalmente por ter as duas imagens lado a lado, o vídeo ainda mais claramente

${ }^{61}$ Conforme matérias publicadas pelo portal G1 da Globo.com: http://g1.globo.com/bahia/gamebahia/2015/noticia/2015/05/fas-de-video-games-declaram-paixao-por-jogos-retro-maisdesafiadores.html. 
produz o sentido de que estudar nessa instituição é tão motivador, dinâmico e divertido quanto jogar videogame. Não há trabalho nem dor nos estudos, apenas prazer, diversão e entretenimento.

As representações do curso de inglês como festa, envolvendo atividades prazerosas e "indolores" são de fato bastante recorrentes, e outras duas campanhas publicitárias são exemplares disso.

\section{Figura 53: Vídeo G - Screenshot 1}

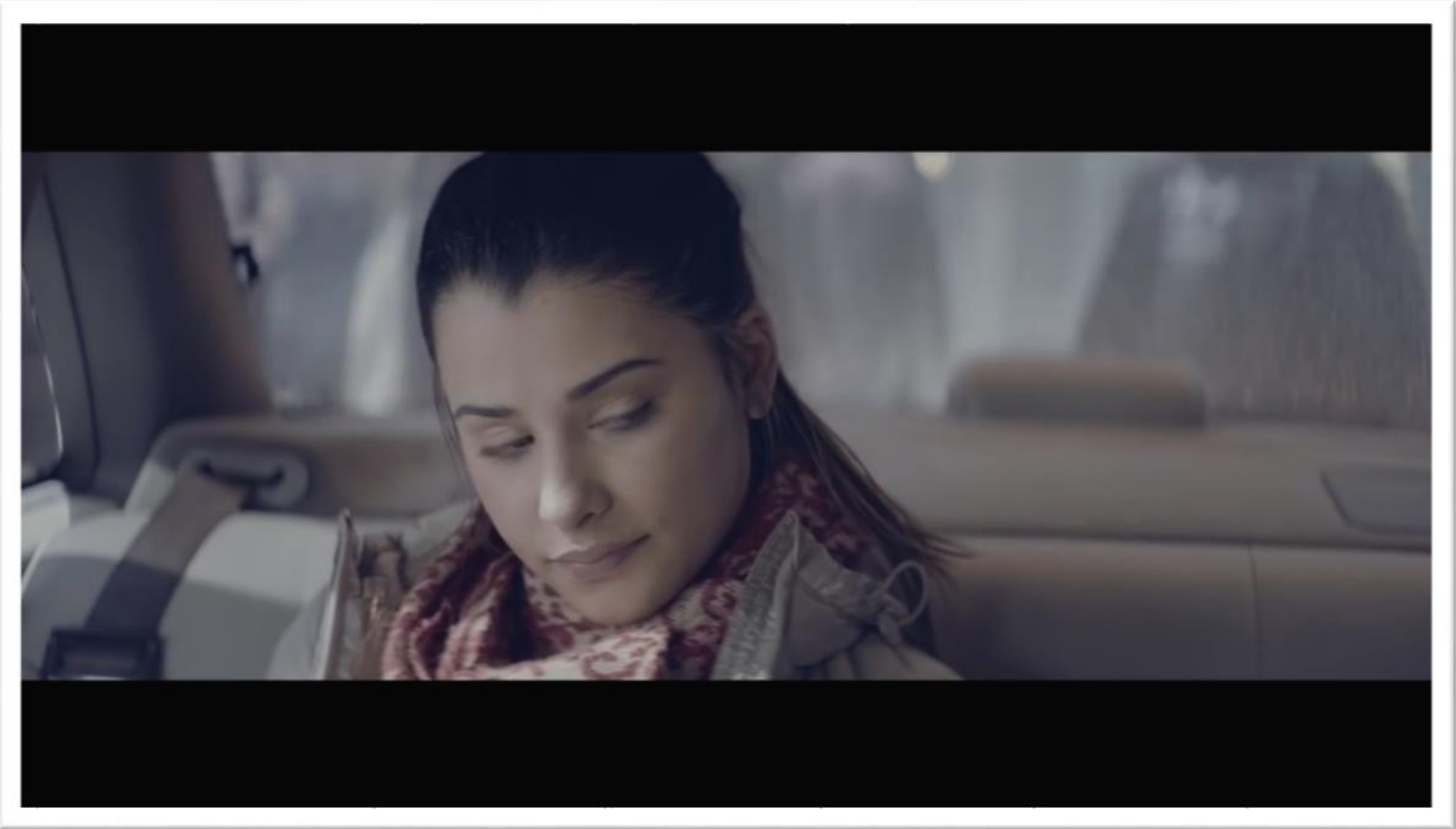

Em uma delas, o vídeo tem sua primeira metade em preto e branco e a participação do narrador desde o princípio. Ela faz um discurso sobre o poder da voz e sua capacidade de "iniciar uma revolução, de romper barreiras, e de levar mais longe", com forte ênfase na palavra "revolução", pronunciada longa e enfaticamente. Durante a fala do narrador, que tem um tom sério e dramático, as cenas mostram multidões se aglomerando em formações que se assemelham a passeatas, e os indivíduos aparecem bradando aos ventos e gesticulando como quem protesta sobre algo. Todos parecem estar se dirigindo a um mesmo lugar.

O narrador então diz que "eles aceitaram o desafio de aprender a falar inglês e venceram", enquanto passamos também a ouvir ao fundo "we are [nome da instituição]' com entonação de torcida. Quando todos finalmente chegam ao ponto de 
encontro, a cena em preto e branco explode em uma festa colorida e animada. A "revolução" é assim representada como uma grande festa. Sendo o mote da instituição é "todos por uma nação bilíngue", pressupondo que essa seja a revolução à qual se refere o narrador, aprender inglês é representado como uma grande festa.

Em outra campanha, fica evidente o processo de aprendizagem sem trabalho e "indolor", semelhante ao vídeo que analisamos com a piada ambientada no cinema, porém de forma mais adulta ou menos infantilizada.

\section{Figura 54: Vídeo G - Screenshot 2}

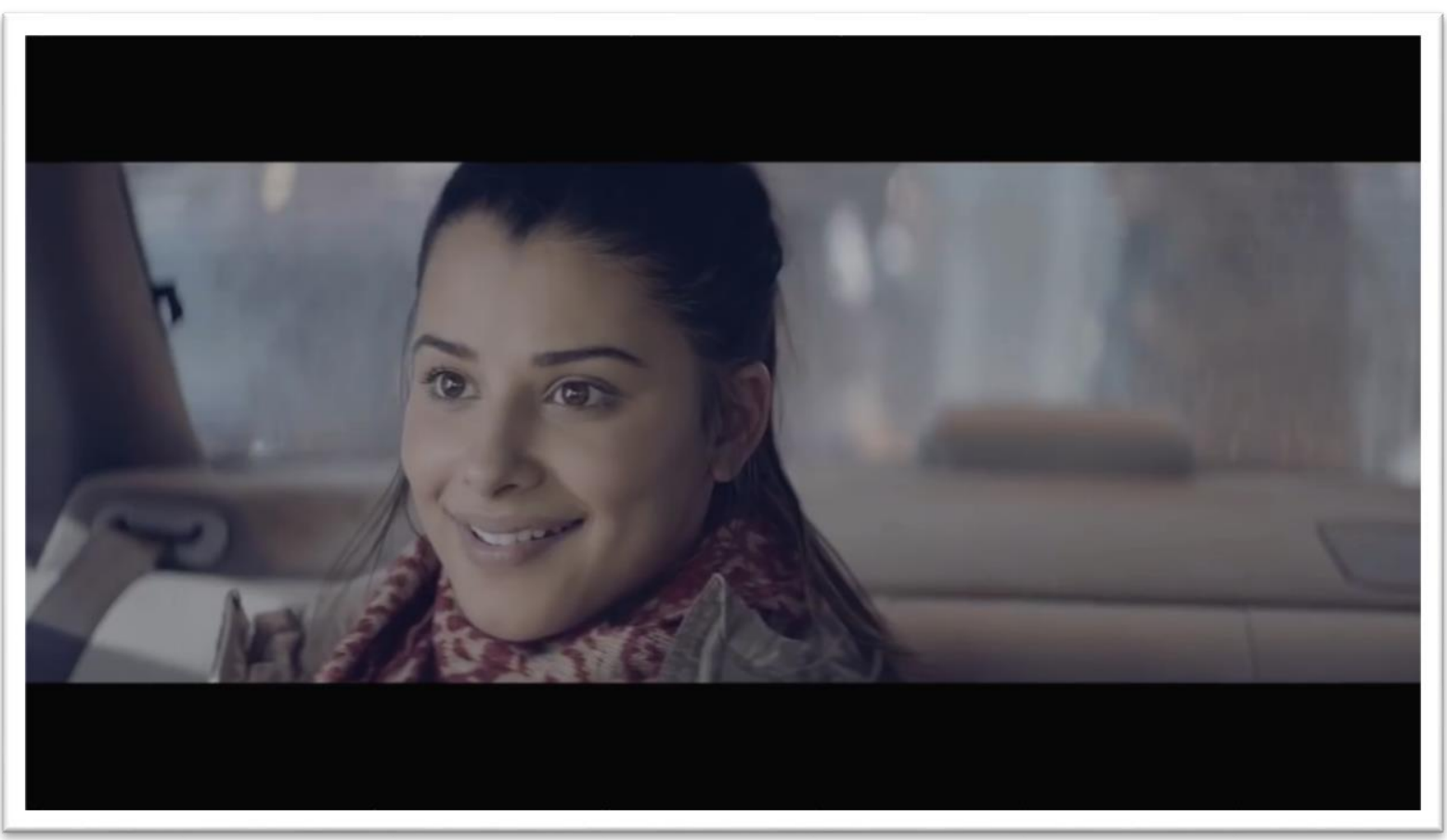

O vídeo tem início com uma mulher entrando em um taxi falando ao telefone com alguém com quem parece ter um relacionamento próximo. $\mathrm{O}$ taxista, em inglês, demonstrando consideração a sua cliente ao telefone, pergunta se ela gostaria que ele abaixasse o volume do rádio. Nesse momento fica explícito que a mulher está em um país onde o inglês é a língua mais comum. Ela responde espontaneamente, também em inglês, que ele, o taxista, não precisa se preocupar, porque ela já havia terminado a ligação. Logo em seguida, um efeito sonoro e a expressão facial da mulher indicam que ela acabou de descobrir alguma coisa, e o narrador imediatamente diz "aquele momento em que você se dá conta que já está falando inglês". 
Assim como no vídeo que analisamos anteriormente, nós nos deparamos com a ideia de que aprender a falar uma outra língua deve ser algo simples, fácil, e sem esforço, de forma implícita em outras atividades do dia a dia. O narrador explicita a "naturalidade" desse processo dizendo que, na instituição anunciante, "você aprende inglês como aprendeu português, e quando você vê, 'you are speaking'”.

\section{Figura 55: Vídeo G - Screenshot 3}

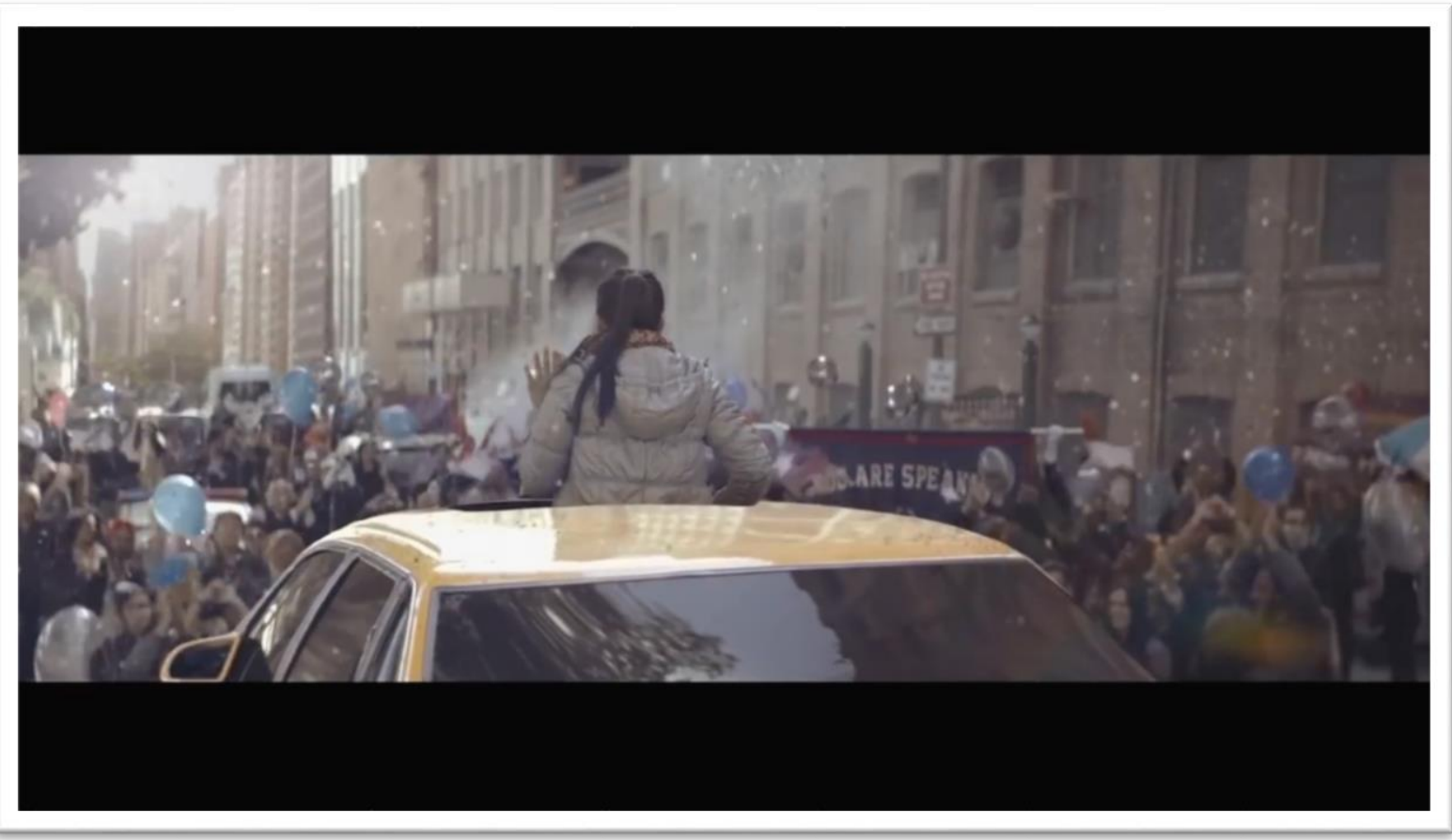

Logo após de seu momento de descoberta, assim como acontece no vídeo que analisamos anteriormente, o evento desemboca em uma gigantesca festa. Há desfiles na rua com faixas onde se lê "you are speaking"; pessoas na rua correndo para encontrar e celebrar junto com a mulher que descobriu falar inglês; faixas caem dos prédios e em todo lugar se lê "you are speaking"; multidões tomam as ruas com balões e confetes ao ar, e a mulher acena para a multidão do alto do seu taxi. Mais uma vez, aprender inglês é representado como uma grande festa.

Não apenas, mas principalmente nos últimos cinco vídeos analisados, há uma aparente "coincidência" entre o discurso cientifico, o senso comum e o discurso da mídia em relação na representação do curso de inglês com características que, por sua vez, coincidem com àquelas atribuídas à interação. 
As características eufóricas trabalhadas como propostas de valor nas peças publicitárias coincidem com as características associadas ao conceito de interação, e aquelas relacionadas ao afeto e ao prazer têm grande importância, assim como aquelas que contrastam com a ineficácia do ensino da escola regular, especialmente nas instituições públicas. Baseando-nos em Gentili e Silva (1994/2001), podemos sustentar que se trata de um processo mais amplo, já que

\begin{abstract}
a construção da política como manipulação do afeto e do sentimento; a transformação do espaço de discussão política em estratégias de convencimento publicitário; a celebração da suposta eficiência e produtividade da iniciativa privada em oposição à ineficiência e ao desperdício dos serviços públicos; a redefinição da cidadania pela qual o agente político se transforma em agente econômico e o cidadão em consumidor, são todos elementos centrais importantes do projeto neoliberal. (GENTILI e SILVA, 1994/2001: 15)
\end{abstract}

Além disso, pode parecer algo curioso que a antítese das "boas" práticas de ensino são representadas nas campanhas publicitárias das escolas de inglês critiquem o ensino regular e não seus concorrentes de mesmo setor. Evidentemente, não é possível afirmar que os publicitários não tenham tido essa intenção (talvez tenham planejado, com suas representações jocosas de outras práticas de ensino, criticar as escolas de idiomas concorrentes) e isso não tem nenhuma importância em nossa análise. Em nossa perspectiva discursiva, a intensão do sujeito empírico não constitui um aspecto a ser considerado. Nossa análise evidenciou que a remissão ao fracasso da escola regular é uma condição de produção dos efeitos de sentido quando são representadas práticas eficazes e não eficazes de ensino de inglês. Em todos os textos analisados, ao representar a ineficiência ou a chatice de uma determinada metodologia ou de padrões de interação, os efeitos de sentido se apoiam na mobilização de elementos da escola regular na memória discursiva. Nos textos analisados, a escola regular é sempre o ícone da antítese das interações ideais.

Baseando-nos nessas evidências, sustentamos que o discurso da mídia publicitária não "impõe à realidade o estereótipo (...)" (CARVALHO, 2014: 24); a sedução da publicidade não está em convencer o interlocutor de que o estereótipo é verdadeiro, nem convencer de que certos elementos devem ser valorizados, mas sim em associar à marca anunciante elementos já aceitos e valorizados. A publicidade não impõe o estereótipo, ela usa e recombina elementos estereotipantes para produzir 
um discurso reconhecível e aceito como verdadeiro, portanto familiar, e ao mesmo tempo percebido como original e criativo.

No desenvolvimento desta parte da análise do corpus, tomando como objeto os textos (vídeos publicitários), pudemos apontar evidências de que a mídia publicitária pode se constituir como um lugar de memória em uma sociedade como a nossa, operando pela reiteração de determinados enunciados e pelo silenciamento de outros. $\mathrm{Na}$ análise, focalizamos as marcas linguísticas dessa reiteração, porque elas deixaram também entrever o caráter reflexivo da influência da discursividade da mídia.

Nessa parte da análise em que tomamos como objeto as peças publicitárias de escolas de inglês focalizando os efeitos de sentido de interação, identificamos que suas modalizações injuntivas se concentram em convencer sobre a eficácia de sua prática e que os sentidos de interação eram pressupostos, não propostos, nem sugeridos. Ou seja, o poder persuasivo da mídia publicitária articula verdades estabelecidas por outros discursos, retomando e reiterando-os, inclusive escamoteando contradições a fim de garantir sua eficácia. Evidentemente, ainda assim é possível sustentar que, como resultado da recorrência da retomada desses enunciados, a mídia também (re)constitui memórias.

Como forma de concluir, nessa instância, não podemos deixar de insistir em algo que talvez não tenha sido suficientemente explicitado. A análise não tratou de estabelecer os limites da influência da mídia publicitária mas sim de levantar evidências do caráter reflexivo dessa influência. Argumentamos que as interpelações, injunções, sugestões e propostas desse discurso funcionam reflexivamente no sentido de que essas modalidades alocutivas no discurso publicitário são eficazes na mesma medida em que se constituem como resposta sujeita a outros discursos.

Essa parte da análise, enfim, problematiza a influência do discurso da mídia publicitária, trabalhando com a ideia de que tal influência é reflexiva, questionando as ideias de que o discurso da mídia seja uma espécie de "cadeia" de discursos e argumentando que os textos publicitários se definem pelo campo problemático criado pela tensão entre os discursos institucionais e os discursos do senso comum. 


\section{Análise do discurso do vendedor}

O texto em análise nesta parte é a transcrição de uma gravação no primeiro semestre de 2016, na qual um vendedor apresenta as características do curso de inglês que pretende vender ao seu interlocutor. Essa e outras gravações são feitas como parte de um projeto contínuo de uma rede de escolas de idiomas chamado "cliente oculto". Nesse projeto, uma empresa é contratada para enviar às escolas da rede pessoas que se passam por clientes e registram o atendimento para fins de verificação de conformidade com os padrões de franquia. Esse texto pode então ser considerado exemplar, considerando que a gravação desse vendedor recebeu um indicador de alta conformidade e, portanto, está de acordo com aquilo que a marca franqueadora procura replicar em suas franquias.

O discurso do vendedor compartilha com o discurso da mídia publicitária um mesmo traço fundamental: ambos são discursos que se pretendem sedutores, com objetivo de levar ao consumo. Por compartilhar esse traço, e por outros fatores que discutimos anteriormente, o discurso do vendedor poderia ser tomado como paráfrase do discurso da mídia publicitária. Porém, nesta parte nossa análise de trechos de diferentes ligações telefônicas com vendedores de curso de inglês mostra pelo menos duas importantes diferenças entre esses discursos, as quais também sustentam o argumento de que o discurso da mídia publicitária é um entre-discursos e que não pode ser tomado como fluxo, nem como ciclo.

A primeira diferença diz respeito ao investimento simbólico que a mídia recebe como lugar de memória. O discurso do vendedor não tem o mesmo status institucional e não recebe esse investimento, o que é decisivo para diversos aspectos do modo de organização enunciativo do discurso do vendedor. Na transcrição abaixo, de um áudio no qual o vendedor fala sobre a metodologia da escola que ele representa ${ }^{62}$, é possível identificar a enorme semelhança que há com a descrição do vídeo $\mathbf{B}$, já que nos dois casos predominam modos argumentativos e descritivos, explicando e tentando convencer o interlocutor de que ele será bem-sucedido em sua aprendizagem do inglês se consumir o curso anunciado ou à venda.

\footnotetext{
"Nós trabalhamos com uma metodologia, [nome omitido], que envolve uma comunicação bem ativa em sala de aula. Você vai estar lendo, vai estar entendendo, vai estar falando e também escrevendo em inglês o tempo todo. As aulas não, não trabalhamos com tradução nas aulas, então você sempre vai estar vendo o idioma mesmo, em inglês, vivenciando situações reais do
}

${ }^{62} \mathrm{~A}$ transcrição se refere ao áudio "televenda 1", entre os anexos, no formato mp3. 
cotidiano mesmo, coisas que você vê no seu dia a dia em português, você vai ver em inglês em sala de aula. $E$ isso facilita o quê? A gente aumenta o seu contato com o idioma e torna mais fácil a sua compreensão. Então você já está... você em sala de aula vai passar por diversas situações em que você tem que utilizar o idioma e isso faz com que você, por exemplo, quando você for fazer uma viagem, uma entrevista de emprego, é, conversar com alguém, por exemplo, você vai estar super tranquila porque você já passou por tudo isso em sala de aula. Então isso é uma coisa muito bacana. Você vê também, você pode ver, durante as aulas, o seu próprio aprendizado. Porque dessa forma, nessa metodologia que a gente trabalha, você consegue ver que, por exemplo, na primeira aula você está entendendo, é, um pouco, na outra você já vai estar entendendo mais, já vai estar conseguindo falar mais palavras, já vai estar conseguindo construir mais frases, e assim você vai reconhecendo o seu próprio aprendizado junto com a nossa metodologia."

No vídeo publicitário analisado, a organização argumentativa se constrói a partir de representações tradicionais da sala de aula de inglês, estabelecendo a como ineficiente, incompleta, desinteressante e ultrapassada. Mesmo que tomássemos como objeto de análise apenas o texto e sua estrutura interna, sem nos situarmos no nível do discurso, poderíamos sustentar que o vídeo constrói essas representações usando os argumentos semióticos de cores de tom pastel, as expressões de marasmo, o "blá, blá, blá" como significante daquilo que é desconexo com o compreensível e o interessante, e outros elementos enunciando tais traços verbalmente. A representação dessa sala de aula envolve comportamentos enunciativos que estabelecem um ponto de vista sobre o mundo com modalidades elocutivas de constatação e não propriamente de argumentação. Neste momento, no vídeo, o papel do locutor é menos o de convencer seu interlocutor e mais o de lembralo da incompletude, da chatice, e da ineficiência da sala de aula tradicional. Não se pretende persuadir o interlocutor de que a sala de aula tradicional seja ineficiente, mas sim de persuadi-lo de que a sala de aula anunciada é diferente, melhor e, principalmente, para aproximar a marca do consumidor por identificação quando a marca e o consumidor concordam com a ideia de que a sala de aula tradicional é ineficiente e tediosa, e que é preciso mais dinamismo na sala de aula. A estrutura argumentativa do vídeo se baseia ou depende de um conceito comum sobre a sala de aula tradicional; uma sala ultrapassada (de ontem), mas presente nos concorrentes: algo como uma memória do agora. A mídia publicitária tem o poder e o dever de se inscrever dessa forma no discurso, retomando, atualizando, e remetendo a essa memória achatada e deshistorizada.

No discurso do vendedor, o locutor de certa forma também constata e lembra seu interlocutor de uma representação do senso comum. Ele apresenta uma descrição 
e argumenta a partir dela. O enunciado "não trabalhamos com tradução nas aulas" estabelece uma representação de escola de inglês tradicional em contraste com uma metodologia "que envolve uma comunicação bem ativa em sala de aula", remetendo também à um domínio de memória. Esse enunciado também é uma resposta a uma pergunta dita, mas já formulada no interdiscurso, ou seja, remete à memória discursiva e ao que já foi dito sobre a sala de aula de inglês baseada em traduções e gramática contrastiva. Mas, sem o status do discurso da mídia publicitária, resta ao locutor aproximar o seu interlocutor do lugar de onde a representação da aula à venda seja positiva e diferente das demais. Enquanto o discurso da mídia publicitária constitui o sujeito-consumidor já na posição de quem disforiza a repetição como prática central de sala de aula, o discurso do vendedor constrói duas representações de metodologia, uma positiva e outra negativa, e uma estrutura retórica que pode procurar deslocar o interlocutor para a posição, em relação a essas representações, a partir da qual a metodologia à venda seja valorizada.

O vendedor não tenta convencer o consumidor de que a tradução é um procedimento ineficiente e tedioso. Não é preciso. Ele apenas marca o contraste com as qualidades da metodologia da marca e ao descrevê-las usa expressões que contrastam com aquilo que é "reconhecidamente" ruim (ineficácia, marasmo), e que se associam com aquilo que é desejável (dinamismo, eficiência): "comunicação bem ativa", "vivenciando", "situações reais do cotidiano", e "utilizar o idioma".

Ao mesmo tempo, a argumentação do vendedor é também uma resposta ao discurso do consumidor que deseja estar em controle e saber o que é dito em inglês a todo momento; uma resposta ao consumidor que deseja a tradução para entender o que é dito na outra língua:

você consegue ver que, por exemplo, na primeira aula você está entendendo, é, um pouco, na outra você já vai estar entendendo mais, já vai estar conseguindo falar mais palavras, já vai estar conseguindo construir mais frases (...)

Eis um argumento que em alguma medida pressupõe que o consumidor tema não compreender o que é dito e não conseguir se expressar exclusivamente em inglês. Levando em conta que a aula completamente em inglês é justamente o que contrata com a abordagem da tradução que é criticada, esse é na verdade um contraargumento e, portanto, incompatível com o discurso da mídia publicitária. O discurso do vendedor não se limita a construir uma representação positiva da instituição e 
convencer o consumidor de que ele pode e deve consumir seus produtos e serviços. $\mathrm{Na}$ verdade, pela natureza desnivelada e alternada da relação de poder que explicitamos anteriormente, o vendedor precisa construir uma representação positiva de si, convencendo o consumidor de que é confiável e que o que diz é verdade. Enquanto o senso comum é suficiente para legitimar as representações no discurso da mídia publicitária, a credibilidade do vendedor é o que sustenta seu dizer como verdade. No primeiro caso, uma voz anônima constata, reapresenta ou reafirma o que é amplamente reconhecido ou reconhecível como uma verdade; enquanto no segundo caso, uma voz suspeita argumenta com o objetivo de levar o outro a consumir em seu próprio benefício. De saída, esse evento discursivo constitui o vendedor como alguém que deve manipular e convencer, colocando-o necessariamente em uma posição de conflito e tornando seu dizer suspeito. É desta posição que o vendedor fala e a partir daí ele é falado em seu discurso. Seus argumentos são menos suspeitos a medida em que o vendedor se constitui em outra posição no discurso; em uma posição com a qual o consumidor possa se identificar ou reconhecer como legítima. Ao dizer "na primeira aula você está entendendo (..) um pouco, na outra você já vai estar entendendo mais", o vendedor se constitui como alguém que também (assim como o consumidor) temeria não compreender uma aula completamente em inglês, se não fosse pela certeza de que pouco a pouco a compreensão aumentaria. Ao dizer "já vai estar conseguindo falar mais palavras, já vai estar conseguindo construir mais frases", o vendedor se constitui como alguém que também valoriza o acúmulo de vocabulário e a compreensão de normas gramaticais. O discurso da mídia publicitária é sedutor porque constata um problema e apresenta uma solução; o discurso do vendedor é manipulador porque sua argumentação pode procurar alterar a posição de onde fala para constituí-lo em posições que melhor qualifiquem seu dizer.

Não é possível identificar marcas linguísticas (heterogeneidade marcada/mostrada) de uma relação de influência ou sobredeterminação do discurso da mídia publicitária sobre o discurso do vendedor, tampouco uma relação de continuidade linear, ainda que cíclica, entre esses discursos. Uma cadeia discursiva implicaria que o vendedor se apoiasse na mídia publicitária, procurando reproduzir situadamente seus efeitos já que, neste caso, em última instância, os objetivos desses dois discursos convergem para levar o consumidor a consumir. Mas a análise evidencia justamente o oposto. No discurso da mídia publicitária, aquilo que é 
retomado como verdadeiro e natural, sedutoramente apresentado, é justamente aquilo que está no centro da argumentação do discurso do vendedor e que, portanto, precisa ser justificado e sustentado.

Ao mesmo tempo, a análise não negligencia a polifonia e a heterogeneidade discursiva do texto. Identificamos, de fato, alguns elementos de concomitância ou de concorrência enunciativa, a partir de espaços discursivos totalmente diferentes e com efeitos diferentes. As semelhanças que apreendemos entre esses discursos, no nível do texto, pela predominância da linguagem argumentativa e seus pressupostos efeitos sedutores, pode produzir essa ilusão, mas, no nível do discurso, os enunciados em questão constituem espaços correlativos ${ }^{63}$ diferentes. $O$ fato dos enunciados pronunciados pelo vendedor serem semelhantes aos enunciados analisados no vídeo B não é evidência de que o vendedor ocupe o mesmo lugar de sujeito que o locutor do vídeo, nem de que foi influenciado por ele; mas simplesmente mostra o poder de repetição intrínseco do enunciado (DELEUZE, 1986/2005; FOUCAULT, 1969/2009). Sob condições diferentes, esses enunciados constituem sujeitos em lugares distintos e, portanto, significam e têm efeitos também diferentes.

$\mathrm{Na}$ representação das aulas, há semelhanças com relação aos tipos de interação. A "comunição ativa" contrasta com as práticas de tradução - "não trabalhamos com traduções" -, que na memória discursiva são associadas a práticas de repetição, e se coaduna com "vivenciar", "dia a dia" e "cotidiano". Ao explicar porque as aulas naquela instituição levarão ao aprendizado, a relação de causalidade se funda na replicação ou simulação do cotidiano em aula, para que possa ser vivenciado em inglês. Os tipos de interação em contraste são repetição e vivência; um contraste muito parecido com o que observamos na análise dos vídeos publicitários. Nesses vídeos, a argumentação é feita de uma posição institucional, por aquele que fala com o status do especialista. Mas o argumento não se reveste de verdade pela força de seu locutor; não se define como verdade pelo suporte institucional ou pelo prestígio do especialista. Ao contrário, em muitos casos, a instituição é que busca o prestígio na mídia publicitária. Na verdade, é justamente pelo

63 Falamos em espaços correlativos conforme Deleuze (1986/2005, p. 18), ou seja, como o espaço no qual se estabelecem relações entre o enunciado e seus sujeitos. 
enunciado ser reconhecido como natural e verdadeiro que o especialista se deixa reconhecer na mídia publicitária64.

Precisamente neste ponto chegamos a outra diferença entre os vídeos analisados e o áudio da venda, qual seja, a ênfase na captação da atenção e interesse do interlocutor, nos vídeos, e na influência sobre o interlocutor para decidir e agir. Nos dois discursos há uma relação de influência, mas ela se configura de forma distinta em cada caso. No discurso da mídia a influência tem uma configuração extremamente tensa e complexa: a mídia publicitária influencia na mesma medida em que é influenciada. A sedução do seu discurso depende do reconhecimento da verdade apresentada como tal e da identificação do consumidor com as posições de sujeito estereotipadas a partir de representações sedimentadas na memória discursiva. 0 investimento simbólico e a função que lhe são atribuídos conferem seu poder, mas não sem lhe tornar objeto desse mesmo poder. No discurso do vendedor há outro tipo de tensão. O vendedor ocupa o lugar de quem deve influenciar, e seu interlocutor, o consumidor, ocupa o lugar daquele que pode ser influenciado. Ou seja, mesmo que a retórica argumentativa seja semelhante nos dois discursos, o espaço correlativo dos enunciados é diferente: as posições dos sujeitos são diferentes entre si e em relação a outros discursos.

No vídeo B, o encadeamento das explicações deve construir uma posiçãosujeito que os consumidores queiram ocupar e que a partir da qual o objeto anunciado seja a escolha certa. O vídeo B não interpela diretamente. Não poderia fazer isso sem perder força. O mecanismo de interpelação funciona melhor quando a retórica é bemsucedida em captar a atenção e gerar o interesse do interlocutor, oferecendo elementos que possam leva-lo a se identificar com a posição-sujeito do consumidor constituído no anúncio. Já os enunciados da venda têm um encadeamento de argumentação que interpelam o consumidor e estabelece uma relação de influência que pretende não exatamente captar a atenção e gerar o interesse, mas sim propor uma decisão a ser tomada e levá-lo a ação de consumir.

\footnotetext{
${ }^{64}$ Devemos considerar que um anúncio pode ter um reconhecido especialista fazendo propaganda de um dado produto e que os efeitos aí poderiam ser outros. Mas mesmo nesse caso, os efeitos de verdade dos enunciados não viriam do fato de estarem sendo pronunciados por um especialista, mas sim pelo fato dele ser um reconhecido (famoso) especialista e, ainda assim, o funcionamento da memória é tal que, em um anúncio, se um especialista fala bem de algo que é reconhecidamente ruim, é antes a sua reputação posta em risco do que o status do produto elevado.
} 
Vejamos o encadeamento de causalidades na argumentação do vendedor:

\begin{tabular}{|c|c|}
\hline Premissa e prescrição da instituição & $\begin{array}{c}\text { "você em sala de aula vai passar por } \\
\text { diversas situações em que você tem que } \\
\text { utilizar o idioma }\end{array}$ \\
\hline $\begin{array}{c}\text { Premissa tomada como primeira } \\
\text { causalidade }\end{array}$ & isso faz com que [...] \\
\hline $\begin{array}{c}\text { Situação hipotética projetada para o } \\
\text { interlocutor e decorrência da premissa }\end{array}$ & $\begin{array}{c}\text { quando você for fazer [...], você vai estar } \\
\text { super tranquila }\end{array}$ \\
\hline $\begin{array}{c}\text { Causalidade (circular) que retorna à } \\
\text { premissa }\end{array}$ & $\begin{array}{c}\text { porque você já passou por tudo isso em } \\
\text { sala de aula }\end{array}$ \\
\hline Conclusão & Então isso é uma coisa muito bacana." \\
\hline
\end{tabular}

Quando o vendedor diz "você" ele estabelece a identidade do consumidor, destacando-o dentre outros interlocutores possíveis de forma que resta a esse interlocutor reconhecer-se nessa identificação. A relação entre os sujeitos é necessariamente desnivelada e alternada. $O$ vendedor exerce influência, propõe, oferece; enquanto o consumidor aceita, resiste ou recusa. Ao mesmo tempo, é o consumidor quem tem o poder de decisão: ele pode perguntar, pedir esclarecimentos e questionar, cabendo ao vendedor explicar, justificar e argumentar. De maneira semelhante ao que ocorre no vídeo $\mathrm{B}$, a retórica pretende levar à conclusão de que 0 curso na instituição é eficiente. O consumidor, audiência do vídeo, pode ocupar ou não na posição-sujeito que lhe é construída, cedendo ou não sua atenção e interesse ao objeto anunciado. O consumidor, como interlocutor do vendedor, pode aceitar ou resistir à argumentação, cedendo ao não a decisão e o ato de consumir.

\section{Análise do discurso do consumidor}

Os textos em análise nessa parte são depoimentos sobre "qual é a melhor forma de se aprender inglês" e sobre "como deve ser uma aula de inglês", coletados de pessoas que declararam que gostariam de aprender inglês ou de ex-alunos que gostariam de voltar a estudar, ou seja, coletados de pessoas que podem ser consideradas como sendo parte do público alvo da publicidade de escolas de inglês. Os sujeitos que podemos apreender nesses textos podem ser considerados em 
alguma medida como constituídos em posições semelhantes àquelas criadas nos textos publicitários analisados.

Na lógica linear do discurso da mídia publicitária como cadeia (chain), esses sujeitos e o discurso do consumidor por implicação são objetos dos efeitos do discurso midiático, que recorrentemente apresentariam marcas de submissão e resistência. Porém, a análise mostra outros tipos de relação entre esses discursos em sua heterogeneidade. Mais uma vez, é importante não perder de vista que os discursos são heterogêneos e não têm limites estanques nem porosos. Seus limites são dados pelas mesmas regras de formação que fazem deles intrinsicamente heterogêneos: há recorrências enunciativas presentes nos dois discursos.

\begin{abstract}
Eu tenho em mente, que primeiro devemos aprender a falar e ouvir e depois estudar gramática, assim como é em nossa língua natural, ninguém nasce e já vai aprendendo gramática, aprender gramática antes de conseguir se comunicar é extremamente maçante, cansativo e desanimador. Não me refiro em ser fluente primeiro e depois começar com a gramática, o ideal é saber se comunicar um pouco e ir estudando a gramática de acordo com a necessidade proposta pelo ensino didático. Mesmo eu acreditando que o inglês é um idioma mais "simples" e direto, em comparação ao português, ele apresenta suas complexidades na gramática, principalmente quando não é possível falar uma frase completa em inglês. Tendo esse ponto de vista, a partir de experiência própria, nos estudos em escolas que frequentei, a aula deve ser estimulada pelo professor, ele deve usar gramática, para explicar determinada estrutura de frase, mas em uma aula deveria ser $10 \%$ do tempo mais ou menos, intercalando durante toda à aula. Do restante o professor pode levar objetos, usar imagens, para associar ao idioma, isso ajuda muito, e também criar alguma situação do cotidiano para que aquelas palavras aprendidas façam sentido. Atividades na internet ajudam também, são interessantes, mas não tanto, quanto a experimentação em sala de aula ou com outro estudante. (Sujeito 1)
\end{abstract}

O enunciado "assim como é em nossa língua natural, ninguém nasce e já vai aprendendo gramática" traz marcas de argumentos que não comumente estão presentes na mídia publicitária, mas sim no discurso acadêmico. As marcas de heterogeneidade desse enunciado apontam menos para a mídia e mais para a ciência do aprendizado de idiomas. O audiolingualismo, que ganhou força nos anos 50 e foi uma abordagem predominante durante muito tempo, especialmente no período de surgimento e crescimento das redes de escolas de idiomas, influenciou forte e profundamente o discurso sobre a aprendizagem de inglês. Os princípios dessa abordagem estão sedimentados na memória discursiva e são retomados e reiterados frequentemente no senso comum. Uma das orientações fundamentais do audiolingualismo é que primeiro o aluno deve exercitar as habilidades orais (ouvir e falar), e apenas posteriormente as habilidades escritas (ler e escrever) devem ser 
produzidas. A premissa é justamente a de que o aprendiz apenas deve ser exposto à escrita quando os padrões da língua oral já estiverem internalizados e automatizados.

Nessa esteira, o enunciado "aprender gramática antes de conseguir se comunicar é extremamente maçante, cansativo e desanimador" remete mais a discursos acadêmicos do que ao argumento midiático. Evidentemente, não se trata de argumentar que em tempos passados, quando outras abordagens no ensino de inglês predominavam (principalmente o método de tradução), aprender a gramática era estimulante e agradável. Não importa determinar se uma dada ação ou prática é "motivadora" ou "desanimadora", se é "divertida" ou "maçante". O ponto chave é justamente o fato dessas determinações serem importantes. Ou seja, não se trata de sustentar que seria possível que em tempos passados as pessoas possivelmente não achavam que aprender gramática era maçante, mas sim de argumentar que em tempos passados não importava se isso era maçante ou não. As marcas da heterogeneidade desse enunciado remetem às ideias pedagógicas que colocam o aluno no centro do processo e que postulam que é fundamental que o aluno seja motivado pelo professor e pelas práticas da aula e que ele queira aprender.

Essas marcas ficam ainda mais explícitas no enunciado:

a aula deve ser estimulada pelo professor, ele deve usar gramática para explicar determinada estrutura de frase, mas em uma aula deveria ser $10 \%$ do tempo mais ou menos, intercalando durante toda à aula. (Sujeito 1)

Ao invés de "conduzida", "trabalhada", "aplicada", "administrada", "direcionada", "orientada", "gerenciada" ou "coordenada", por exemplo, aqui "a aula deve ser estimulada pelo professor". Conforme discutimos anteriormente, o estímulo, a motivação e o dinamismo são valores neoliberais associados a espetacularização da sociedade e o consumo do entretenimento. No entanto, devemos observar que nesse enunciado o professor é representado como aquele que tem o papel de estimular. Não se diz, por exemplo, "nós alunos devemos encontrar formas de nos manter motivados e de aplicar na prática a gramática que estudamos em sala". Cabe ao professor concretizar esses ideais, conforme a expectativa do aluno que é, por sua vez, cliente da escola e produto do e para o mercado. Para tanto, "o professor pode levar objetos, usar imagens para associar ao idioma [...] e também criar alguma situação do cotidiano para que aquelas palavras aprendidas façam sentido".

A "chatice" também aparece como elemento importante da aula de inglês em outra resposta: 
A melhor forma de aprender inglês seria dialogando e exercitando a capacidade de fazer perguntas. Essa é uma ótima técnica para aprender. Primeiro do que tudo, a aula de inglês tem que ser divertida e com muita conversação e claro com um pouco de teoria. Se a aula é somente focada em escrita as aulas ficam chatas e em inúmeras vezes ficam difíceis de aprender. (Sujeito 2)

Em consonância com o texto anterior, especialmente ao afirmar que a aula deveria ter " $10 \%$ do tempo mais ou menos" para explicações sobre as estruturas da língua, o enunciado "primeiro do que tudo, a aula de inglês tem que ser divertida e com muita conversação e claro com um pouco de teoria" é evidência do reconhecimento da importância da "teoria", que pode ser inferida como relativa às explicações gramaticais, mas ao mesmo tempo a estabelece como secundária. A palavra "claro" poderia marcar a importância da teoria como óbvia, mas, nesse caso, seu efeito de sentido é o que obviamente deve haver teoria em pequena quantidade. No texto é a conversação que tem proeminência: "a melhor forma de aprender inglês seria dialogando e exercitando a capacidade de fazer perguntas". A teoria seria algo como um tempero ou um toque especial para outro ingrediente, a conversação, que, este sim, deve ser abundante.

A conversação é associada a ideia de dinamismo e tem uma conotação de prática prazerosa, em contraste com a chatice da prática escritas ("Se a aula é somente focada em escrita as aulas ficam chatas"). Porém, o prazer e o dinamismo da conversação têm importância metodológica nesse texto, de forma que eles importam como meio de aprender e como lazeres paralelos, e ganham status de "técnica": "Essa é uma ótima técnica para aprender".

Assim como no texto anterior, a diversão não é apenas um elemento que deve estar presente para que os momentos em sala de aula sejam mais prazerosos, mas é tido como determinante para o sucesso da aprendizagem. Da mesma forma que evidenciamos na análise dos vídeos publicitários, não se trata de se divertir enquanto aprende, mas sim de aprender se divertindo. A diversão em si é tida como um meio para se aprender e seu avesso, a chatice, é tida como obstáculo: "as aulas ficam chatas e em inúmeras vezes ficam difíceis de aprender". Nessa instância, é crucial que não percamos de vista que essa representação do processo de aprendizagem no qual a diversão tem uma importância central não está presente na engrenagem argumentativa do discurso da mídia publicitária, e sim no conjunto das modalidades 
enunciativas que constituem um pano de fundo para os argumentos, retomando e reiterando memórias discursivas.

Em outro texto, esses argumentos também podem ser apreendidos.

A melhor forma para aprender inglês é a imersão total na língua, ou seja, o aluno em questão participar de algum intercâmbio no qual possa viver no país por pelo menos dois anos. Com relação ao formato da aula, é imprescindível que o professor(a) tenha vivência no exterior. As melhores professoras que já tive moraram no mínimo 4 anos na Inglaterra/Estados Unidos. A gramática é importante, mas o que muitas escolas erram e fazem o aluno perder o interesse ou mesmo ter dificuldades com o idioma é que, focam $80 \%$ na gramática. Estudei em uma escola que a gramática era "dissolvida" ao longo das lições e dessa forma a fixação do aprendizado era muito melhor. (Sujeito 3)

Além da mitologização da língua inglesa e da idealização do professor nativo, que são questões que decidimos não abordar nesta tese, a "imersão total na língua" também pode remeter a ideia do processo de aprendizagem centrado na prática e no dia a dia. Nesse sentido, "criar alguma situação do cotidiano" (sujeito 1), pode ser interpretado como uma forma de reproduzir situações de imersão na língua, principalmente se considerarmos o quanto é apregoada a ideia de que as aulas de inglês devem ser conduzidas exclusivamente em inglês, conforme evidenciamos na análise do discurso do vendedor.

Mais uma vez, a gramática aparece como necessária e, ao mesmo tempo, como obstáculo para a motivação e o aprendizado, sendo apenas admitida em pequenas doses: "a gramática é importante, mas o que muitas escolas erram e fazem o aluno perder o interesse ou mesmo ter dificuldades com o idioma é que, focam $80 \%$ na gramática" (grifo nosso). Ao ocupar o espaço da aula que deveria ser das práticas que simulam o dia a dia, a gramática não apenas desestimula, mas também faz um desserviço para o processo de aprendizagem, levando os alunos a terem dificuldades com o idioma. No texto, as práticas de sala de aula são mais eficazes quando o ensino da gramática pode ser pouco percebido pelos alunos: "estudei em uma escola que a gramática era "dissolvida" ao longo das lições e dessa forma a fixação do aprendizado era muito melhor".

\section{Análise do discurso do professor}

Os textos em análise aqui são respostas sobre a pergunta "qual é a melhor forma de se aprender inglês" e sobre "como deve ser uma aula de inglês", coletadas 
de pessoas que declararam ser professores especialistas no ensino de inglês, ou seja, são coletadas de pessoas que podem ser consideradas como sendo os profissionais que prestam o serviço anunciado nos vídeos publicitários analisadas. São também pessoas que tem acesso a conhecimentos e orientações, mais ou menos prescritivas (seja pela instituição onde trabalham, livro didático, parâmetros curriculares, etc.) sobre como se deve ensinar e aprender inglês.

Na lógica linear do discurso da mídia publicitária como cadeia (chain), esses sujeitos no discurso do professor seriam aqueles em nome de cuja expertise o anúncio falaria, e cujos conceitos o discurso da mídia se apropriaria. Porém, a análise mostra outros tipos de relação entre esses discursos.

A melhor forma de se aprender inglês é com aulas regulares e bem orientadas, com exposição frequente ao idioma e com muito esforço e dedicação. Não há milagres! A aula de inglês deve ser contextualizada, com chances para o aluno adquirir e usar o idioma. (Professor 1)

O texto evidencia o papel do aluno em termos bastante diferentes do que é anunciado nos vídeos publicitários. É preciso "muito esforço de dedicação" para se aprender. Outros elementos são apontados como importantes, mas o enunciado "não há milagres!", inclusive por sua expressão exclamativa, enfatiza o esforço e a dedicação, principalmente como resposta à tão presente ideia de que é desejável que se aprenda inglês de forma rápida, fácil e divertida, o que seria como um milagre, presumindo-se essas condições de aprendizagem seriam utópicas. Ainda que de forma menos enfática, essas condições de esforço e dedicação por parte do aluno também são marcadas no texto do professor 2 e do professor 3.

\section{A melhor forma de aprender inglês é com a metodologia comunicativa com contato diário com músicas, séries, filmes e leituras extras, combinando diferentes tipos de atividades feitas com auxilio de um professor e self- study. (Professor 2)}

"Self-study" remete à ideia de uma relativa autonomia do aluno, de seu empenho individual em estudar novos conteúdos e em consolidar o que é estudado "com auxílio de um professor", e de sua responsabilidade e comprometimento em relação a seu próprio processo de aprendizagem.

Eu acredito que seja na escola de idiomas, com auxílio de um professor experiente e com suporte tecnológico. Também acredito que depende muito do aluno se esforçar, ao realizar as tarefas e buscar materiais extras, além de filmes e seriados. (Professor 3)

"Depende muito do aluno se esforçar" também coloca em evidência a dedicação do aluno. O uso de "depende" contrasta com outras construções como "é 
importante" ou "é desejável" no sentido de estabelecer o esforço do aluno como "condição" do aprendizado e não como algo que pode acrescentar algum benefício ao processo. O uso do advérbio "muito" reitera a importância do empenho e do esforço.

A ideia de esforço não aparece do texto do professor 4 , que enfatiza a combinação de trabalhos em sala e fora dela e atribui bastante importância à forma do professor conduzir a aula de forma a criar espaços e oportunidades para que os alunos possam ser protagonistas da sua aprendizagem.

\begin{abstract}
Acredito que a melhor forma de aprender inglês é através da combinação do direcionamento formal de um professor, que vai indicar os caminhos, atalhos e estratégias para o aprendizado, com o uso frequente do idioma em situações cotidianas, assistindo filmes, lendo livros, ouvindo música e praticando com colegas pessoalmente ou através da internet as habilidades de conversação. Quanto maior a intensidade destas atividades, maior a velocidade do aprendizado. Uma aula de inglês deve despertar a curiosidade dos alunos através de temas e discussões relevantes aos seus interesses, além de despertar o desejo de conseguir produzir mais língua com maior qualidade. Deve ser composta por desafios que façam com que os alunos reúnam sua gama de conhecimentos anteriores e da aula corrente para atingir os objetivos. O papel do professor deve ser o de facilitador, apontando os caminhos para desenvolvimento e criando oportunidades para prática e produção dos conteúdos em um ambiente seguro e de colaboração. (Professor 4)
\end{abstract}

O professor deve "indicar os caminhos, atalhos e estratégias", mas é o aluno quem trilha esses caminhos, quem tomas os atalhos e quem aplica as estratégias. Ou seja, pressupõe-se uma intensa participação do aluno que é tida como decisiva para o aprendizado. O "uso frequente" do idioma além da aula de inglês também pressupõe um certo nível de engajamento e comprometimento do aluno com os estudos e as práticas do idioma, já que é preciso que ele trabalhe além da sala de aula.

Esses elementos não silenciados nos vídeos que anunciam os cursos de escolas de idiomas. É difícil imaginar que algum anúncio de curso de inglês pudesse dizer algo como "se você está pronto para se dedicar a estudar inglês, venha para nossa escola".Talsilenciamento é evidência de que não se tratam de discursos encadeados, nem permite sustentar que o discurso da mídia se aproprie do discurso do especialista, tampouco que o especialista penetre ou entre no discurso da mídia. O sujeito que fala no discurso da mídia publicitária se constitui entre (in between) as posições do especialista, da instituição anunciante e da instituição midiática, e seu dizer está sujeito ao verdadeiro do senso comum institucionalizado.

Há diversas recorrências nos vídeos anunciantes de cursos de inglês também estão presentes nesses textos: a aula ser conduzida em inglês; a aplicação prática do 
idioma; a ancoragem das práticas de estudo e aprendizagem em situações cotidianas; e a ênfase em conversação. No texto do professor um, a aula deve promover "exposição frequente" e "contextualizada" ao inglês, e prevê que o aluno de fato deve "usar o idioma". Nos textos do professor 2 e do professor 3, o "contato diário com músicas, séries, filmes e leituras extras" é importante. No texto do professor 4, "o uso frequente do idioma em situações cotidianas, assistindo filmes, lendo livros, ouvindo música e praticando com colegas pessoalmente ou através da internet as habilidades de conversação" é essencial para a aprendizagem. Essas recorrências em comum, menos enfáticas no discurso do professor e mais centrais nos vídeos dos anúncios, é evidência de que aquilo que se diz no discurso da mídia publicitária deve soar natural, verdadeiro e sustentável cientificamente. No caso do discurso da mídia publicitária, o efeito de verdade não é produzido exatamente pelo prestígio de quem fala, nem pelas instituições que corroboram esse dizer, apesar desses fatores terem um papel na ordem do discurso, mas sim pelos mecanismos de produção de dizeres que se apresentam como pressupostos familiares e naturalizados; que se apresentem como algo já sedimentado na memória discursiva e frequentemente reiterado como verdadeiro.

\section{Conclusões}

Neste capítulo questionamos a ideia de que o discurso da mídia exerça maior influência sobre sua "audiência", que os textos veiculados na mídia são prontos e reproduzíveis e que no discurso da mídia há uma disjunção temporal e espacial entre as instâncias de produção e de consumo de textos. Sustentamos que o "consumo" do texto midiático não é posterior à sua veiculação, mas acontece desde o momento mesmo de construção do texto que se pretende veiculado, e que ele não se define pelo meio de comunicação nem pela posição de sujeito de quem fala. $O$ discurso da mídia publicitária se define pelo campo problemático criado pelos nós de coerção dos discursos institucionais (inclusive do senso comum). Este tem a particularidade de ser um discurso "entre" (in between) discursos, adiado, latente e constituído por um complexo de coerções para (re)produção de discursos. Ou seja, o modo de funcionamento do discurso da mídia publicitária é mais eficiente em seduzir para o consumo na medida em que mais se submete a dizer o mesmo, a reproduzir aquilo 
que é aceito como verdadeiro por aqueles com quem ela deseja falar. O discurso da mídia não argumenta para defender conceitos, mas os apresenta de forma que sirvam para argumentar em favor do valor de consumo e para produzir o desejo por ele.

As análises mostram como o discurso da mídia publicitária mobiliza memórias discursivas que têm marcas reconhecíveis em outros discursos, em uma engrenagem que apresenta seu discurso como verdadeiro. Não há modalidades enunciativas argumentativas na apresentação do conceito de interação justamente porque isso comprometeria o modo de funcionamento desse discurso sedutor. $O$ ato de argumentar estabeleceria o conceito como uma proposição ou alegação, enfraquecendo o caráter sedutor da proposta do valor de consumo. Este é mais sedutor em contraste com um pressuposto reconhecidamente verdadeiro e com o qual os sujeitos possam se identificar. 


\section{Considerações Finais}

The fact of agreement rather than being a proof of the stability of objects, is a testimony to the power of an interpretive community to constitute the objects upon which its members (also and simultaneously constituted) can than agree. [...] Disagreements are not settled by the facts, but are the means by which the facts are settled.

Stanley Fish

A análise das condições sócio-históricas do discurso da mídia publicitária em anúncios de cursos livres de inglês e das regularidades da formação do discurso da mídia publicitária sobre interação em cursos de inglês, a reflexão teórica sobre os mecanismos discursivos que mobilizam o poder de influência do discurso da mídia publicitária e a revisão da literatura sobre o conceito de interação corroboram nossa tese de que o discurso da mídia publicitária não exerce senão uma influência condicional sobre outros discursos, inclusive sobre o científico. Mostramos evidências de que esse discurso é sujeito a regras de uma ordem que interditam o engendramento de conceitos no interior de sua própria formação discursiva.

As regularidades da formação discursiva do discurso da mídia publicitária e as regras de dispersão desse discurso nos níveis dos objetos, dos tipos enunciativos, 
dos temas e teorias não apresentam, separadamente, uma lógica substancialmente distinta de outras formações. No entanto, as regras de dispersão no nível do conceito operam de forma sensivelmente distinta de outras formações, nas quais os enunciados já formulados em outras partes podem ser retomados tanto como verdade presumida e necessária, quanto como algo a ser criticado, discutido, julgado ou rejeitado. No caso do discurso da mídia publicitária, os campos de presença e de concomitância, assim como o domínio de memória das formas de coexistência dos conceitos são fundamentalmente singulares. O campo de presença, nesse discurso, interdita a instauração de relações da ordem da verificação, da experimentação, da investigação e da proposição, e potencializa as relações da ordem da repetição e da aceitação justificada pela tradição. Nessa esteira, seu o campo de concomitância tem um efeito esterilizante sobre os enunciados retomados, já que não estão sujeitos a análise e verificação, por exemplo. Seu domínio de memória, por sua vez, conforme dissemos, é achatado ao ponto de não poder se distinguir do campo de presença, já que os laços de transformação e de continuidade-descontinuidade histórica não se estabelecerem e dos enunciados tratarem sempre do agora, mesmo ao falar do passado. Isso significa que os lugares e posições de enunciação no discurso da mídia publicitária apenas podem mobilizar poder na mesma teia de relações que conjuram seus poderes, limitando seu potencial criativo às temáticas, aos objetos e tipos enunciativos, e interditando sua apropriação de regras de formação de conceitos.

Dessa forma, afirmamos que as representações publicitárias da interação que as salas de aula e as novas tecnologias proporcionam fazem parte de uma engrenagem de influência e submissão que articula processos de atualização, no sentido deleuziano (DELEUZE, 1988/2006), de memórias discursivas. O ensino e aprendizagem de inglês e a interação são de fato representados e exacerbados como experiências eficazes, prazerosas, agradáveis, encantadoras e afetuosas, no caso das escolas de cursos livres, e ineficazes, tediosas, maçantes, fastidiosas, enfadonhas e requerendo muito esforço, no caso das escolas do ensino regular. Ao mesmo tempo, sustentamos que o discurso da mídia publicitária sobre a sala de aula de língua inglesa em escolas de idiomas e os tipos de interação associadas a ela constitui um sistema de dispersão que mobiliza, reitera, sedimenta e retoma sentidos de tal forma que cria o efeito ilusório de coincidência com outros discursos, a partir da qual poder-se-ia presumir que há uma relação de influência. Conforme afirmamos 
anteriormente, quando vemos alguém dizer ou fazer algo que se vê na mídia, apressada e inadvertidamente poder-se-ia concluir que esse alguém está a reproduzir comportamentos veiculados, sendo a mídia a influenciadora ou manipuladora e sua audiência a influenciada ou manipulada, sujeita inclusive às necessidades e vontades supostamente incitados pela mídia. Poder-se-ia também presumir que a mídia, em especial a mídia jornalística e a publicitária, tem mecanismos de apresentação de seus objetos e conceitos de forma a serem recebidos como verdadeiros, em uma cadeira discursiva da produção à recepção. Tais presunções, defendemos, são insuficientes para a compreensão da complexidade do discurso da mídia publicitária. Refletindo sobre o modo de funcionamento do discurso da mídia publicitária e analisando representações da sala de aula de escolas de inglês, concluímos que não há mecanismos coercivos nesse discurso que visem a sustentação de um conceito ou a imposição de um objeto. Evidenciamos mecanismos de apresentação de um objeto como mercadoria em direta associação com valores notoriamente prestimosos e desejáveis, cujo funcionamento é tão eficiente e sedutor quanto maior for a submissão do discurso da mídia publicitária àquilo sedimentado na memória discursiva como verdadeiro e a retórica associativa dos valores em relação ao objeto. Eis o modo de funcionamento do discurso da mídia publicitária ao representar a sala de aula de língua inglesa em contextos de escolas de cursos livres associada a determinado conceito de interação, evidenciado pelas análises e sustentado teoricamente pelas reflexões sobre os mecanismos discursivos que mobilizam o poder de influência do discurso da mídia publicitária.

As reflexões teóricas e análises (principalmente no sentido de compreender o modo de funcionamento do discurso midiático com relação aos mecanismos discursivos que mobilizam o poder de influência do discurso da mídia publicitária) se constituíram como crítica às perspectivas que abordam a dinâmica de produção e circulação de sentidos midiatizados como fluxo de produção e de recepção publicitária. O fluxo da produção, no nosso no caso dos textos publicitários que analisamos, seria constituído pelos anúncios e comerciais sobre a educação veiculados nos vários suportes midiáticos que permeiam o cotidiano dos indivíduos, mas principalmente os suportes impressos e os em mídia digital. Esse polo da produção de mensagens envolveria os anunciantes, agências e meios de comunicação, e se oporia ao polo da audiência consumidora, implicando que o fluxo 
da recepção seja "a observação de como estas mensagens são incorporadas pelos indivíduos em seus contextos de recepção" (PIEDRAS, 2006, p. 68). No entanto, sistematicamente questionamos e problematizamos a existência desses dois fluxos e compreendemos que não se trata exatamente de uma influência do discurso midiático sobre outro discurso ou outras práticas sociais. Trata-se de complexas práticas de valores simbólicos (portanto, ideológicos) que constituem discursos que não têm uma relação de determinação, mas de coerção e mútua influência.

Além de corroborar essas conclusões sobre o discurso da mídia publicitária, a análise das condições sócio-históricas do discurso da mídia publicitária em anúncios de cursos livres de inglês e a análise das regularidades da formação do discurso da mídia publicitária sobre interação em cursos de inglês também foram subsídio para nossa reflexão sobre o conceito de interação e interatividade. Pudemos sustentar que não são as peculiaridades da apropriação do conceito de interação pela mídia que o embebe em valores eufóricos, e evidenciamos que o próprio discurso acadêmico submete a tratamento cientificista a ideia de interação associada a valores neoliberais, como o dinamismo e o entretenimento. Em uma lógica de causalidade linear, a interação e a interatividade são um conjunto de traços que podem ser determinantes para a existência ou não da interação entre sujeitos presentes ao mesmo tempo, ou para classificações de diferentes tipos de interação, compreendidas como um continuum da pior à melhor interatividade, sendo as melhores interações aquelas que têm mais ou os melhores traços interativos.

Nessa lógica a interação é como um fluxo de ações que tem certas características desejáveis e que tem duas ou várias direções entre sujeitos, com ou sem mediação de tecnologias. Criticamos essa lógica argumentando que é justamente a interação que atualiza a presença dos sujeitos, produzindo seus efeitos e que, portanto, a interação não coincide com as "ações" e se constitui como relações entre eventos, objetos e sujeitos. Argumentamos também que é nessa tensão relacional que está a potencialidade produtiva de uma dada atividade, e apresentamos um referencial teórico-prático para reflexão sobre tal potencialidade. Em última instância, argumentamos que não há traços intrinsicamente positivos que garantam a produtividade de uma interação, mas que é preciso compreender quais elementos estão em jogo nas relações entre sujeitos, eventos e objetos para avaliar potenciais da interação. Nesse sentido, falar em "qualidade" da interação não deve remeter a 
busca de traços desejáveis, mas sim em avaliar os contingentes efeitos dos elementos em jogo.

Inclusive ao examinarmos como os mecanismos de persuasão operam nos textos midiáticos publicitários e ao problematizarmos a ideia de interação e interatividade usada para descrever os objetos e as relações das escolas de inglês representadas nos meios de comunicação midiáticos, essa perspectiva é crítica das práticas de consumo envolvendo "interação e interatividade" como valor simbólico, ou seja, como um efeito de sentido que é reificado e banhado em positividade e consumido em práticas discursivas. Afinal, devemos ter em mente que o discurso científico, em grande medida, é produzido sob semelhantes condições sócio-históricas do discurso da mídia publicitária. 


\section{Referências Bibliográficas}

ATZ, A. P.; ROCHA, L. S. A influência da publicidade na sociedade de consumo e sua regulação pelo CDC. IX Salão de Iniciação Científica. Porto Alegre: PUCRS, 2008.

BAKHTIN, M. Marxism and the philosophy of language. London: Seminar Press, $1929 / 1973$.

BARBOSA, I.S.; TRINDADE, E. Por uma enunciação publicitária. II Congresso Latino-Americano de Estudos do Discurso. Anais. Puebla: Universidad Autónoma Benemérita de Puebla/ALED, 2003.

BAUMAN, Z. Globalização: as consequências humanas. Rio de Janeiro: Zahar, 1999.

BORDEWIJK, J. L. \& KAAM, B. Towards a new classification of tele-information services. Intermedia. v. 14, n. 1, p. 16-21, 1986.

BRANDÃO, H. H. N. Introdução à análise do discurso. Campinas: Unicamp, 2004.

BRASIL. Secretaria de Educação Básica. Linguagens, códigos e suas tecnologias. Brasília: Ministério da Educação, 2006.

CANCLINI, N. G. Consumidores e cidadãos: conflitos multiculturais da globalização. Rio de Janeiro: Editora UFRJ, 1995.

CANCLINI, N. G. Culturas híbridas: estratégias para entrar e sair da modernidade. São Paulo: EDUSP, 1997.

CARÁ JR., J. Sujeitos virtuais e seus efeitos de presença: relações de poder no ciberespaço. 2011. 148 f. Dissertação (Mestrado em Estudos Linguísticos e 
Literários em Inglês) - Faculdade de Filosofia, Letras e Ciências Humanas, Universidade de São Paulo, São Paulo. 2011.

CARÁ JR., J. Educação sem distância: efeitos de presença em cursos on-line. São Paulo: Biblioteca 24 horas, 2014.

CAREY, J. Interactive Media. In: BARNOUW, E. (Ed.). International Encyclopedia of Communications. New York: Oxford University Press, 1989. p. 328-330.

CARMAGNANI, A. M. G. A argumentação e o discurso jornalístico: a questão da heterogeneidade em jornais ingleses e brasileiros. 1996. $349 \mathrm{f}$. Tese (Doutorado em Linguística Aplicada ao Ensino de Línguas) - Pontifícia Universidade Católica de São Paulo, São Paulo. 1996.

CARMAGNANI, A. M. G. Técnicas de vigilância e punição: o discurso da mídia sobre o professor e a escola. Verso e Reverso. v. 18, n. 39, p. 1-13, 2004.

CARMAGNANI, A. M. G. A Babel controlada: mídia e representação de língua(s) estrangeira(s). In: CORACINI, M. J.; CARMAGNANI, A. M. G. (Orgs.) Mídia, exclusão e ensino: dilemas e desafios na contemporaneidade. Campinas: Pontes, 2014. p. 341-355.

CARVALHO, N. O texto publicitário na sala de aula. São Paulo: Editora Contexto, 2014.

CASTRO, G. G. S.; ROCHA, R. M. Cultura da mídia, cultura do consumo: imagem e espetáculo no discurso pós-moderno. Logos 30: Tecnologias de Comunicação e Subjetividade. v 16, n. 1, p. 48-59, 2009.

CHARAUDEAU, P. Discurso das mídias. São Paulo: Contexto, 2006.

CHARAUDEAU, P.; MAINGUENEAU, D. Dicionário de análise do discurso. São Paulo: Contexto, 2004/2008.

COULDRY, N. Media rituals: a critical approach. London: Routledge, 2003.

DAY, G. S. Organizing for interactivity. Journal of Interactive Marketing. v. 12, n. 1, p. 47-53, 1998.

DEBORD, G. A sociedade do espetáculo. Rio de Janeiro: Contraponto, 1997/2013.

DEL MONTE, M. H. L. A influência da publicidade televisiva no consumo da população de classe C: os anunciantes do varejo popular. 2011. 128 f. Dissertação (Mestrado em Interfaces Sociais da Comunicação) - Escola de Comunicação e artes, Universidade de São Paulo, São Paulo. 2011.

DELEUZE, G. Foucault. Lisboa: Edições 70, 1986/2005.

DELEUZE, G. Diferença e repetição. São Paulo: Graal, 1988/2006.

DELEUZE, G. Conversações. São Paulo: Editora 34, 1992/2010.

DELEUZE, G. O atual e o virtual. In: ALLIEZ, E. Deleuze: filosofia virtual. São Paulo: Editora 34, 1996. p. 47-59.

DELEUZE, G.; GUATTARI, F. Mil Platôs. Vol. 1. São Paulo: Editora 34, 1995.

DELEUZE, G.; GUATTARI, F. Mil Platôs. Vol. 2. São Paulo: Editora 34, 1995/2011.

DERRIDA, J. Gramatologia. São Paulo: Perspectiva, 2000/2008. 
DUFOUR, D. R. Uma nova condição humana: os extravios do indivíduo-sujeito. Trad. Selvino J. Assmann. Paris: Le Monde Diplomatique, 2001.

DUFOUR, D. R. A arte de reduzir as cabeças. Rio de Janeiro: Companhia de Freud, 2005.

ECOSTEGUY, A. C.; JACKS, N. Comunicação e recepção. São Paulo: Hacker Editories, 2005.

FAIRCLOUGH, N. Media discourse. London: Bloomsbury, 1995/2010.

FONTANILLE, J.; ZILBERBERG, C. Tensão e significação. São Paulo: Humanitas, 2001.

FOUCAULT, M. A arqueologia do saber. Rio de Janeiro: Forense Universitária, 1969/2009.

FOUCAULT, M. A ordem do discurso. São Paulo: Loyola, 1971/2008.

FOUCAULT, M. Microfísica do poder. Rio de Janeiro: Graal, 1979/2008.

GENTILI, P. A. A.; SILVA, T. T. da. Neoliberalismo, qualidade total e educação. Petrópolis: Vozes, 2001.

GRIGOLETTO, M. Língua inglesa na mídia brasileira: efeitos da construção de uma memória. In: CORACINI, M. J.; GHIRALDELO, C. M. (Orgs.) Nas malhas do discurso: memória, imaginário e subjetividade. Campinas: Pontes, 2011. p. 297-315.

HA, L.; JAMES, L. Interactivity re-examined: a baseline analysis of early business web sites. Journal of Broadcasting \& Electronic Media. v. 42, n. 4, p. 457-474, 1998.

HAECKEL, S. H. About the nature and future of interactive marketing. Journal of Interactive Marketing. v. 12, n. 1, p. 63-71, 1998.

HALL, S. A identidade cultural na pós-modernidade. Rio de Janeiro: DP\&A, 2006.

HEETER, C. Implications of new interactive technologies for conceptualizing communication. In: BRYANT, J.; SALVAGGIO, J. L. (Eds.) Media use in the information age: emerging patterns of adoption and computer use. Hillsdale: L. Erlbaum Associates, 1989. p. 217-235.

HEETER, C. Interactivity in the Context of Designed Experiences. Journal of Interactive Advertising. v. 1, n. 1, p. 4-15, 2000.

HOFFMAN, D. L.; NOVAK, T. P. Marketing in hypermedia computer-mediated environments: conceptual foundations. Journal of Marketing. v. 60, n. 3, p. 50-68, 1996.

JENSEN, J. F. Interactivity: tracking a new concept in media and communication studies. Nordicom Review. v. 19, n. 1, p. 185-204, 1998.

KIOUSIS, S. Interactivity: a concept explication. New Media \& Society. v. 4, n. 3, p. 355-383, 1999.

LANDOWSKI, E. Presenças do outro: ensaios de sociossemiótica. São Paulo:

Perspectiva, 2002.

LÉVY, P. Cibercultura. São Paulo: Editora 34, 1999. 
LOMBARD, M.; SNYDER-DUTCH, J. Interactive advertising and presence: a framework. Journal of Interactive Advertising. v. 1, n. 2, p. 56-65, 2001.

MALDIDIER, D. Inquietação do discurso: (re)ler Michel Pêcheux hoje. Campinas: Pontes, 2003.

MATTELART, A.; MATTELART, M. História das teorias de comunicação. São Paulo: Loyola, 1999.

MAZIÈRE, F. Análise do Discurso: história e práticas. São Paulo: Parábola Editorial, 2005.

MCMILLAN, S. J.; DOWNES, E. J. Defining interactivity: a qualitative identification of key dimensions. New Media \& Society. v. 2, n. 2, p. 157-179, 2000.

MILES, I. When mediation is the message: how suppliers envisage new markets. In: LEA, M. (Ed.) Contexts of computer-mediated communication. New York: Harvester Wheatsheaf, 1992. p. 145-167.

NEWHAGEN, J. E. et al. Nightly@nbc.com: audience scope and the perception of interactivity in viewer mail on the internet. Journal of Communication. v. 43, n. 3, p. 164-175, 1996.

NORA, P. Entre história e memória: a problemática dos lugares. Revista Projeto História. v. 10, p. 7-28, 1993.

NUNAN, D. Research Methods in Language Learning. Cambridge: Cambridge University Press, 1992.

ORLANDI, E. P. Análise do discurso: princípios e procedimentos. Campinas: Pontes, 1999/2009.

PAVLIK, K. V. New media technology: cultural and commercial perspectives. Boston: Allyn and Bacon, 1998.

PIAGET, J. A Construção do Real na Criança. Rio de Janeiro: Zahar, 1970.

PIEDRAS, E. R. As práticas de recepção da publicidade como fluxo: apontamentos teórico-metodológicos. Contemporanea. v. 5, n. 1-2, pp. 1-18. 2007.

PIEDRAS, E. R. Fluxo publicitário: anúncios, produtos e receptores. Porto Alegre: Sulina, 2009.

RAFAELI, S. Interactivity: from new media to communication. In: HAWKINS, R. P. et al. (Eds.) Advancing communication science: merging mass and interpersonal processes. SAGE Annual Review of Communication Research, v. 18. 1988. p. 110134.

RAMOZZI-CHIAROTTINO, Z. Em busca do sentido da obra de Jean Piaget. São Paulo: Ática, 1984.

REBER, A. Implicit learning and tacit knowledge. New York: Oxford University Press, 1993.

REUSSER, K. Co-constructivism in educational theory and practice. In: SMELSER, N. J.; BALTES, P. B. (Eds.) International Encyclopedia of the Social \& Behavioral Sciences. Oxford: Elsevier: 2001. p. 2058-2062. 
SANTAELLA, L. Corpo e comunicação: sintoma da cultura. São Paulo: Paulus, 2004.

SAVIANI, D. História das ideias pedagógicas no Brasil. Campinas: Autores Associados, 2007/2010.

SILVA, M. Que é Interatividade. Boletim Técnico do Senac. v. 24, n. 2, p. 26-35, 1998.

SILVA, M. Sala de aula interativa. Rio de Janeiro: Quartet, 2000.

SILVA, M. Indicadores de interatividade para o professor presencial e online. Revista Diálogo Educacional. v. 4, n.12, p. 93-109, 2004.

SILVA, T. T. da. A "nova" direita e as transformações na pedagogia da política e na política da pedagogia. In: GENTILI, P. A. A.; SILVA, T. T. da. (Orgs.) Neoliberalismo, qualidade total e educação: visões críticas. Petrópolis: Vozes, 1994/2012. p. 9-29.

STEUER, J. Defining virtual reality: dimensions determining telepresence. Journal of Communication. v. 42, n. 4, p. 73-93, 1992.

STRAUBHAAR, J.; LAROSE, R. Communications media in the information society. Belmont: Wadsworth Press, 1996.

THOMPSON, J. A mídia e a modernidade: uma teoria social da mídia. Petrópolis: Vozes, 1998.

TORI, R. Educação sem distância: as tecnologias interativas na redução de distâncias em ensino e aprendizagem. São Paulo: Senac, 2010.

TRINDADE, E. Diretrizes para uma teoria da enunciação da recepção publicitária. Intercom - Revista Brasileira de Ciências da Comunicação. v. 31, n. 2, p. 35-54, 2008.

VAN LEEUWEN, T. Genre and field in critical discourse analysis. Discourse \& Society. v. 4, n. 2, p. 193-223, 1993.

VYGOTSKY, L. S. Mind in society. Cambridge: Harvard University Press, 1978.

WAGNER, E. D. In support of a functional definition of interaction. American Journal of Distance Education. v. 8, n. 2, p. 6-26, 1994. 


\section{Anexos}

\begin{tabular}{|l|c|}
\hline \multicolumn{2}{|c|}{ Vídeo A } \\
\hline Título do arquivo no DVD & Aprenda inglês com o zumbi medroso \\
\hline Extensão do arquivo no DVD & MP4 \\
\hline Link do vídeo/áudio & https://www.youtube.com/watch?v=zOybnJHIJiA \\
\hline Link do canal do vídeo & https://www.youtube.com/channel/UCqIoOYHKEDIFXMJAEZYLm8w \\
\hline
\end{tabular}

\section{Vídeo B}

\begin{tabular}{|l|c|}
\hline Título do arquivo no DVD & Aqui seu filho aprende brincando \\
\hline Extensão do arquivo no DVD & MP4 \\
\hline Link do vídeo/áudio & https://www.youtube.com/watch?v=8JDCAvFQo-8 \\
\hline Link do canal do vídeo & https://www.youtube.com/channel/UCsDOmPLNwT4b1M9pJWtpbsg \\
\hline
\end{tabular}

\begin{tabular}{|l|c|}
\hline \multicolumn{2}{|c|}{ Vídeo C } \\
\hline Título do arquivo no DVD & Por que funciona? \\
\hline Extensão do arquivo no DVD & MP4 \\
\hline Link do vídeo/áudio & https://www.youtube.com/watch?v=wrFv135sYME \\
\hline Link do canal do vídeo/áudio & https://www.youtube.com/user/CanalCCAA \\
\hline
\end{tabular}




\begin{tabular}{|l|c|}
\hline \multicolumn{2}{|c|}{ Vídeo D } \\
\hline Título do arquivo no DVD & Por que funciona? \\
\hline Extensão do arquivo no DVD & MP4 \\
\hline Link do vídeo/áudio & https://www.youtube.com/watch?v=C-bzQzOFIyU \\
\hline Link do canal do vídeo/áudio & https://www.youtube.com/user/FiskBrasil \\
\hline
\end{tabular}

\begin{tabular}{|l|c|}
\hline \multicolumn{2}{|c|}{ Vídeo E } \\
\hline Título do arquivo no DVD & Por que funciona? \\
\hline Extensão do arquivo no DVD & MP4 \\
\hline Link do vídeo/áudio & https://www.youtube.com/watch?v=L-s_qqOuBUg \\
\hline Link do canal do vídeo/áudio & https://www.youtube.com/user/cnaoficial \\
\hline
\end{tabular}

\begin{tabular}{|l|c|}
\hline \multicolumn{2}{|c|}{ Vídeo F } \\
\hline Título do arquivo no DVD & Por que funciona? \\
\hline Extensão do arquivo no DVD & MP4 \\
\hline Link do vídeo/áudio & https://www.youtube.com/watch?v=WHQMMD95Poc \\
\hline Link do canal do vídeo/áudio & https://www.youtube.com/user/WizardBrazil \\
\hline
\end{tabular}

\begin{tabular}{|l|c|}
\hline \multicolumn{2}{|c|}{ Áudio A } \\
\hline Título do arquivo no DVD & Cliente Oculto \\
\hline Extensão do arquivo no DVD & MP4 \\
\hline Link do vídeo/áudio & - \\
\hline Link do canal do vídeo/áudio & - \\
\hline
\end{tabular}

